Florida International University FIU Digital Commons

$12-13-2001$

\title{
Lower Manhattan and the East River: an investigation into the renewal of the Lower East Side waterfront
}

Todd A. Edge

Florida International University

DOI: $10.25148 /$ etd.FI15101265

Follow this and additional works at: https:// digitalcommons.fiu.edu/etd

Part of the Architecture Commons

\section{Recommended Citation}

Edge, Todd A., "Lower Manhattan and the East River: an investigation into the renewal of the Lower East Side waterfront" (2001). FIU Electronic Theses and Dissertations. 3232.

https://digitalcommons.fiu.edu/etd/3232 
FLORIDA INTERNATIONAL UNIVERSITY

Miami, Florida

LOWER MANHATTAN AND THE EAST RIVER: AN INVESTIGATION INTO THE

RENEWAL OF THE LOWER EAST SIDE WATERFRONT

\author{
A thesis submitted in partial fulfillment of the \\ requirements for the degree of \\ MASTER OF ARCHITECTURE
}

by

Todd A. Edge 
To: Dean Juan Bueno

School of Architecture

This thesis, written by Todd A. Edge, and entitled Lower Manhattan and the East River: An Investigation into the Renewal of the Lower East Side Waterfront, having been approved in respect to style and intellectual content, is referred to you for judgement.

We have read this thesis and recommend that it be approved.

Luke McGregor

Marilys Nepomechie

\section{Date of Defense: December 13, 2001}

The thesis of Todd A. Edge is approved.

Florida International University, 2001 


\section{DEDICATION}

I dedicate this thesis to my family, for without their support and love this work would not have been possible. I would also like to dedicate this work to all of the families who lost loved ones during the September 11, 2001 attacks on the World Trade Center Twin Towers. 
I wish to thank the members of my committee for their guidance, support, and influence. Professor Camilo Rosales has been a major influence on my architectural studies and theories Professor Marilys Nepomechie has been equally involved in directing me through the early design phases and always pushing me for more. I will always look to and respect these two individuals as I one day hope to be their equal. Lastly, I cannot forget to thank the third member of my committee, the engineer who always said 'no', Luke McGregor. Working with a structural engineer is always a challenge for an architect, and even more so for an architectural student, but Luke made this thesis fun and kept me going with his jovial attitude. 
LOWER MANHATTAN AND THE EAST RIVER:

AN INVESTIGATION INTO THE RENEWAL OF THE LOWER EAST SIDE WATERFRONT

by

Todd Edge

Florida International University, 2001

Miami, Florida

Professor Camilo Rosales, Major Professor

With the mid-20 $0^{\text {th }}$ Century construction of an elevated highway along Manhattan's East River, the declining neighborhood of the Lower East Side was removed from its waterfront. As cities begin to re-examine their edges, I feel it is appropriate to address the issues of the Lower East Side community and its former riverfront. Utilizing the recent developments in Manhattan, London, and Chicago as a basis for determining how metropolitan areas are attempting to reconnect with their shores, a set of questions were developed, analyzed, and then applied to the Lower East Side. With the analysis of these questions providing the groundwork for the project, the main concern turns to the elevated highway that has cut through the community along the water's edge. There are three possible solutions for the future of this 'wall' in order to reconnect the Lower East Side with the East River. The first two solutions examine the idea of demolishing the elevated FDR Drive in favor of subterranean or surface streets. The other solution examines the possibility of redesigning the existing elevated highway. In the end, the project focuses on an urban design and planning program that re-establishes the connections between the community and the waterfront. 
I. Introduction to Waterfronts

II. History and Development of the New York Waterfront

III. Decline of New York's Waterfront

IV. Waterfront Rejuvenation in the Late $20^{\text {th }}$ Century

a. Manhattan

$$
\begin{aligned}
& \text { South Street Seaport } \\
& \text { Chelsea Piers }
\end{aligned}
$$

Battery Park City

b. London:

$$
\begin{aligned}
& \text { Docklands } \\
& \text { Isle of Dogs }
\end{aligned}
$$

Canary Wharf

c. Chicago:

$$
\text { Lake Michigan Development }
$$

Navy Pier

V. A Case for Redevelopment of the Lower East Side Neighborhood

a. Lower East Side and its History

b. The Franklin D. Roosevelt East River Drive

c. Recent Proposals and Projects Near the Lower East Side

d. Current Conditions of the Site

VI. Thesis Project Introduction

VII. The Thesis Semester

VIII. The Thesis Design Project

a. Existing Conditions: Site Model Photographs

b. Design Intervention

IX. End Notes

X. Bibliography

XI. Appendices 
Unless otherwise noted, figures and photographs contained within the work are the property of the author and may have been taken in either March 1998, September 1999, June 2000 or August 2001. AutoCAD drawings, renderings, and photomontages were produced during the Fall Semester 2001.

2. New York map (1766). From Eric Homberger's, The Historical Atlas of New York City, page 36

3. Graphic of New York (late $18^{\text {th }}$ to early $19^{\text {th }}$ centuries). From Eric Homberger's, The Historical Atlas of New York City, pages 62-63.

4. Map of Hudson River growth (1699-1856). From Ann L. Buttenwieser's, Manhattan WaterBound, page 33 .

5. Early photograph of New York docks. From Ann L. Buttenwieser's, Manhattan WaterBound, page 59 .

6. Sectional drawing of Chelsea Piers (1907). From Kevin Bone's, The New York Waterfront page 72 .

7. Photograph of Chelsea Piers under construction (1909). From Ann L. Buttenwieser's, Manhattan Water-Bound, page 97.

8. Elevation drawings of Chelsea Piers (1907). From Kevin Bone's, The New York Waterfront page 73 .

9. View of Manhattan from Brooklyn (1876). From Ric Burns and James Sanders', New York: An Illustrated History, pages 170-171

10. Brooklyn Naval Yards. From Kevin Bone's, The New York Waterfront, page 171.

11. Brooklyn Naval Yards. From Kevin Bone's, The New York Waterfront, page 172.

12. Proposal for Jamaica Bay (1919). From Kevin Bone's, The New York Waterfront, page 78.

13. Through 16. Derelict Piers around New York (1992-1993). From Kevin Bone's, The New York Waterfront, pages 150-151.

17. Port of New York Terminal at the Chelsea Piers (1957). From Ric Burns and James Sanders', New York: An Illustrated History, page 471.

19. Isometric depiction of South Street Seaport and Fulton Market. From South Street Seaport Directory Brochure.

20. View north along the Hudson River (1996). From Kevin Bone's, The New York Waterfront, page 236 . 
21. Chelsea Piers Sports and Entertainment Complex (advertisement). From the (helsea Piers Sports \& Entertainment Brochure.

22. and 23. Map and plans of the Chelsea Piers. From Anthony Iannacci's, Butler Rogers Baskett: Revitalizing the Waterfront, pages 16-17.

24. Derelict dock at Battery Park City site (1960`s). From David Gordon. Battery Park City page 6.

25. Figure Ground of 1979 Masterplan. From David Gordon, Battery Park City, page 67.

26. Proposal for Battery Park City in 1969. From David Gordon, Battery Park City, page 28

28. Lefrak and Fisher's Pod III design for Battery Park City. From David Gordon, Battery Park City, page 51.

30. London docks in 1919. From Cynthia Grant and Simon Borthwick's, Photo Docklands, page

31. Westminster's Covent Garden. From Susan Fainstein's, The City Builders, page 42.

32. One Canada Square in the Canary Wharf. From Janet Foster's, Docklands: Cultures in Conflict, Worlds in Collision, page 167.

33. Row of residences on the Isle of Dogs. From Janet Foster's, Docklands: Cultures in Conflict, Worlds in Collision, page 333.

34. Map of the Isle of Dogs (1930). From Janet Foster's, Docklands: Cultures in Conflict. Worlds in Collision, page 26.

35. Model of the redeveloped Canary Wharf. From Sue Brownill's, Developing London's Docklands, page 55 .

36. Image of the Canary Wharf and the Isle of Dogs. From Patrick Malone's, City, capital, and water, page 54.

37. Millenium Dome and One Canada Square. From Janet Foster's, Docklands: Cultures in Conflict, Worlds in Collision, page 353.

38. Photograph of Koetter Kim and Associates' model for Western Segment. Alan Plattus, Colin Rowe, and Fred Koetter, Koetter Kim \& Associates: Place/Time, page 73.

39. Photograph of Chicago's docks (late 1800's). From The Lakefront Plan of Chicago, page 8.

40. Photograph of Lake Michigan and landfill activity (1928). From The Lakefront Plan of Chicago, page 9 .

41. Map of Chicago and Lake Michigan (1967). From Harold M. Mayer and Richard C. Wade's, Chicago: Growth of a Metropolis, page 443. 
42. Map of Chicago River (1834). From Harold M. Mayer and Richard C. Wade's, Chicago: Growth of a Metropolis, page 21 .

43. Photograph of Grant Park in Chicago (1947). ). From Harold M Mayer and Richard C Wade's, Chicago Growth of a Metropolis, page 297.

44. Photograph of Chicago's Navy Pier. From Ann Breen and Dick Rigby's, The New Waterfront, page 84

45. Internet photograph of the Navy Pier. From http//www chicago il org/NAVYPIER.HTML

46. Lake Shore Drive along Chicago's Lake Michigan. From The Lakefront Plan of Chicago, page 17 .

48. Graphic cutaway of tenement building. From Eric Homberger's, The Historical Atlas of New York City, page 111

49. and 50. Graphics of proposals for FDR Drive and the Lower East Side (1930's). From Ann L. Buttenwieser's, Manhattan Water-Bound, pages 174-175.

51. Current Internet image of FDR Drive. From

http //www. geocities.com/SoHo/Canvas/2228/fdr/ph/dr htm

52. FDR Drive as photographed in 1949. From

http //www geocities. com/SoHo/Canvas/2228/fdr/phfdr.htm

53. Current Internet image of FDR Drive. From

http $/ /$ www geocities.com/SoHo/Canvas/2228/fdr/phfdr. htm

57. Drawing of Robert Venturi's East River Park (1973). From Rebecca Read Shanor's, The City That Never Was, page $x v$

59. Computer rendering of Pei Cobb Freed's design for Manhattan waterfront site near the U.N Building. From John E. Czarnecki's article, "Pei Cobb Freed and SOM to plan NYC East River site," Architectural Record, page 28

60. through 62. Photographs of Frank Gehry's model of the new Guggenheim for Manhattan From various sources including Frank Gehry's and Guggenheim Museum's websites, Architecture, Architectural Record, and other publications. I have personally viewed and photographed Gehry's model when it was displayed at the Solomon R. Guggenheim Museum in New York, June 2000.

64. and 65. Computer imagery and plans of Asymptote's proposal the Museum of Technology Culture. From Susan Stefans and Clifford Pearson's article, "Asymptote envisions a sleek and dynamic Museum of Technology Culture," Architectural Record. pages 93 and 95.

66. through 68 and 70. Images of Santiago Calatrava's bridges. The Oresund, the Orleans, the Alcoy, and the East London River Crossing. Photographs are from the architect's website (http.//www. calatrava.com) 


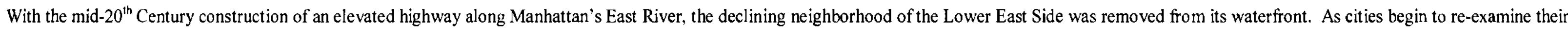

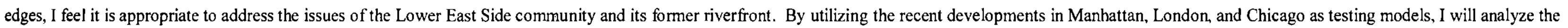
possibilities and determine a means of reconnecting the Lower East Side community to its once thriving waterfront.

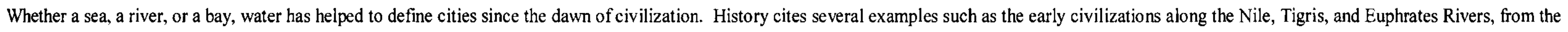

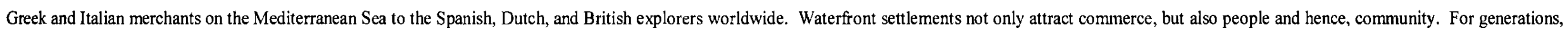

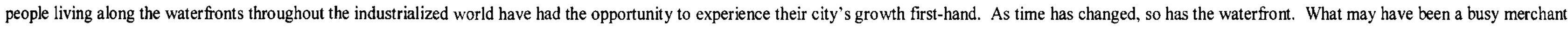

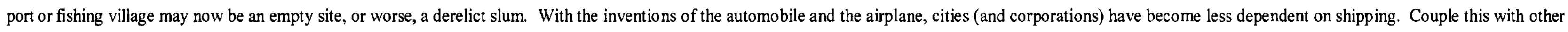

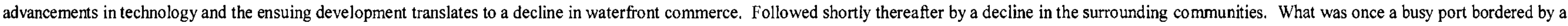
prosperous neighborhood, could easily become a slum with an abandoned waterfront.

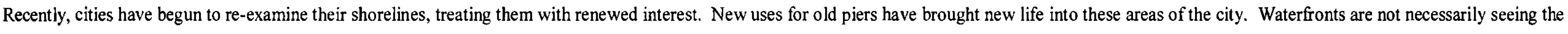

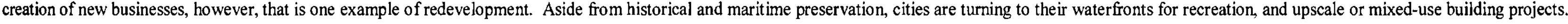

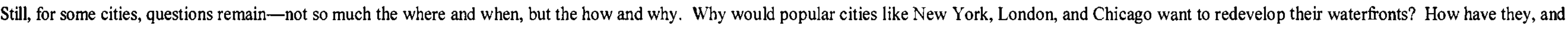

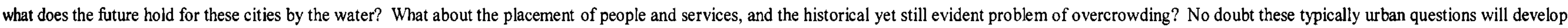

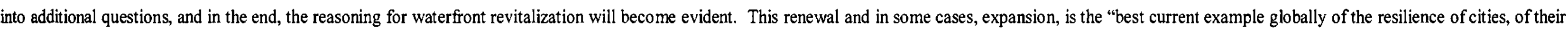

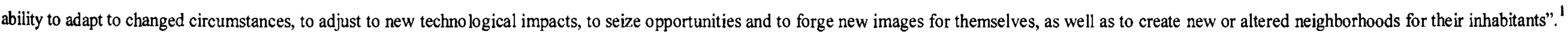




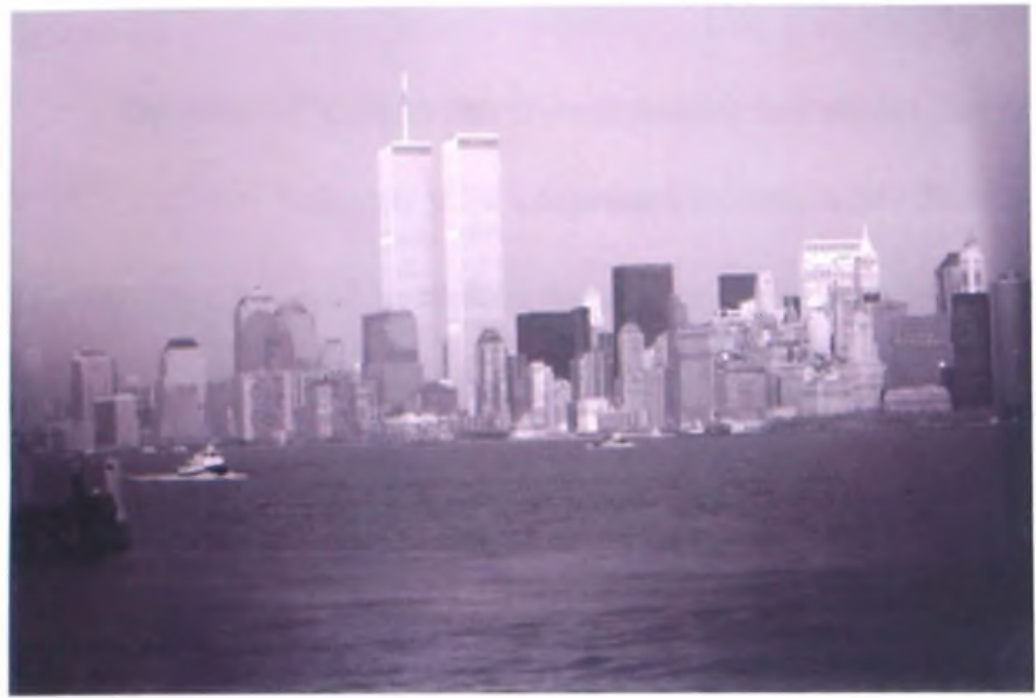

Figure 1:

One of the most famous skylines and waterfronts in all the world Manhattan

As the town on the southern tip of Manhattan grew (see figure 2), the port became its heart. The East River waterfront became focused on shipping and commerce. As the waters became lined with merchant vessels, the land became engrossed with those closely linked to the industry-ship's workers and other associated industries (including taverns) set-up their shops all along the waterfront. The New York waterfront prospered, and this prosperity spread through the small port town that was so closely linked to it. Not even the periods of war could stop its growth. During Great Britain's war with the French and Indians, the Hudson River became the main artery for British ships and New York's merchants grew immensely rich. ${ }^{5}$ Although the war's end would greatly decrease the colony's businesses, taxation would lead to its revolt. As New York joined the rest of the American colonies, the Revolutionary War did not hurt the port city like the rest of the colonies New York was generally regarded as a Tory ${ }^{6}$ haven
Topography and location, obviously the key elements of any waterfront city, have been taken full advantage of by the City of New York. Since its inception, New York, particularly the island of Manhattan, has always been unique. New York (New Amsterdam to the first settlers from the Dutch West India Company) was founded as a business colony, not as a religious settlement like the other colonies. ${ }^{2}$ New York, its people, and its waterfront have been intricately linked from the first Dutch trading post to a thriving port to the financial 'dock' of corporations throughout the world. What began in the year 162 l as New Amsterdam, a Dutch settlement and port, became the English town of New York in $1664 .^{3}$ As the English surpassed the Dutch in world trade; New York became a key maritime entity. "By 1740, New York had become the third largest port in the British Empire, second only to Philadelphia and London itself.,4 


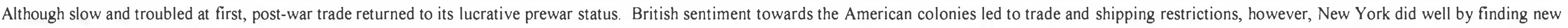
trading patterns and partners, especially in the Far East. The expansion of trade and increase in manufacturing were central to the city's growth.

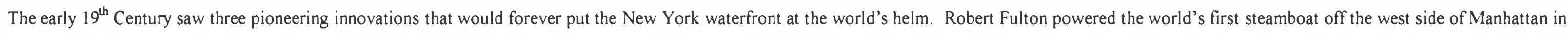

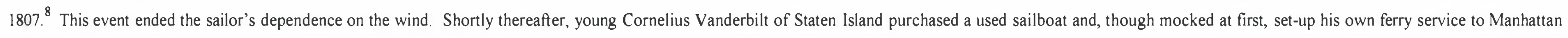

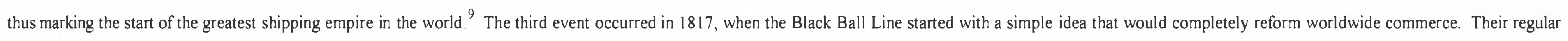

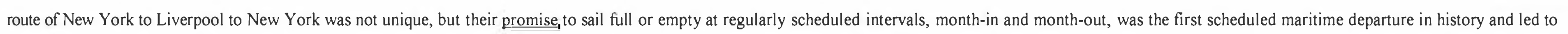
the world's first true shipping line. ${ }^{10}$

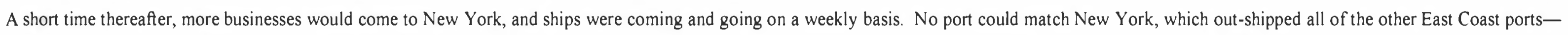
combined! Regular schedules, high quantities, and numerous foreign destinations turned the two-mile stretch of piers and shipyards along the South Street waterfront into the 'street of ships'.

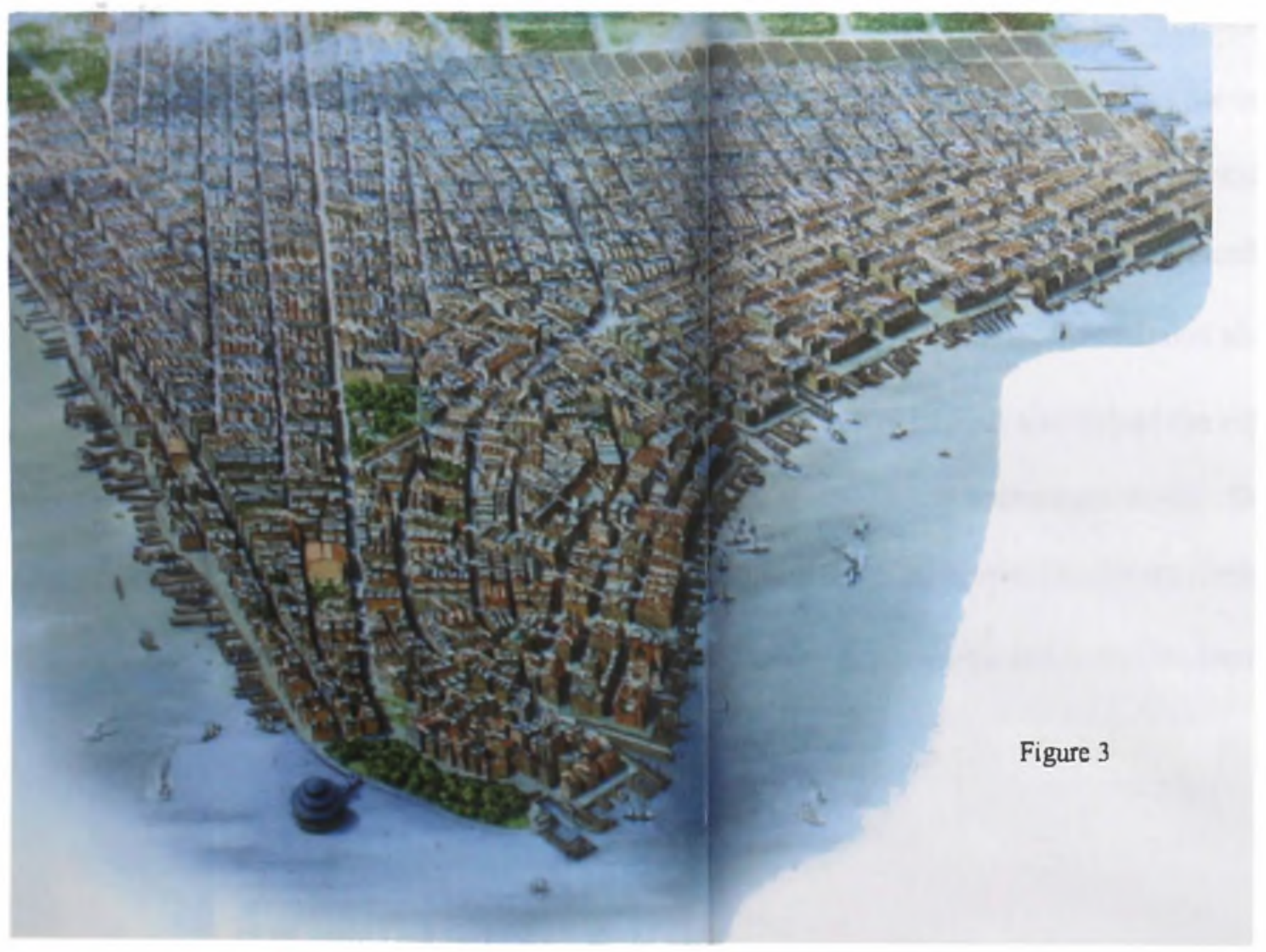

The Manhattan side of the East River was not the only bustling realm along New York's waterfront. The Hudson River side, especially the area now known as the Battery, was the location for the growing immigration. Smaller trade ships also used the Hudson River for northern trade. Meanwhile, the Brooklyn side of the East River became a holding area for ships trying to access the piers and docks off South Street. "In 1840, there were sixty-three wharves on the East River, and fifty on the Hudson. Docking facilities were beginning to develop in Brooklyn and Jersey City" (refer to figure 3). ${ }^{11}$

As steamer lines and clipper sailing ships raced each other out of New York and back, to and from ports all over the world, ship designers and builders were busy searching for sleek designs and larger volumes. As the population of Manhattan grew, so did the ferry services of the other boroughs and New Jersey. Likewise the goods and wares found on New York's docks and piers had to make way for a new business-passengers. While immigrants were trying to get into New York, the socialites of America and Europe wanted to 'see the world' and visit the exotic ports of call that brought 


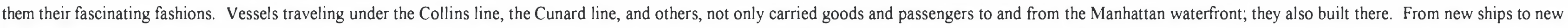

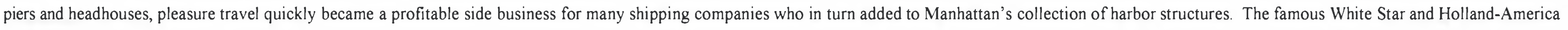
lines would later enter New York's waters, jockeying for space.

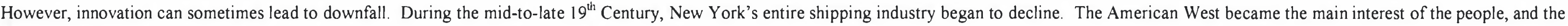

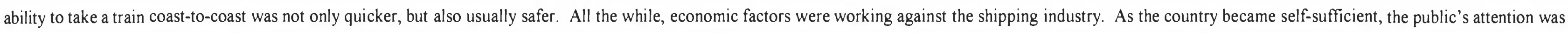

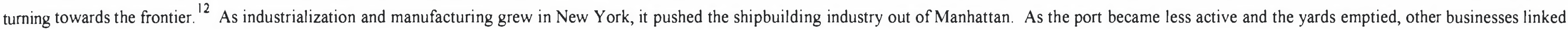

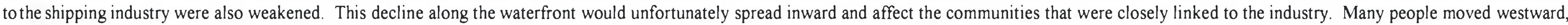

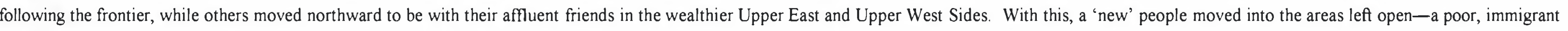
population, many of whom settled into the Lower East Side and Lower Hudson areas.

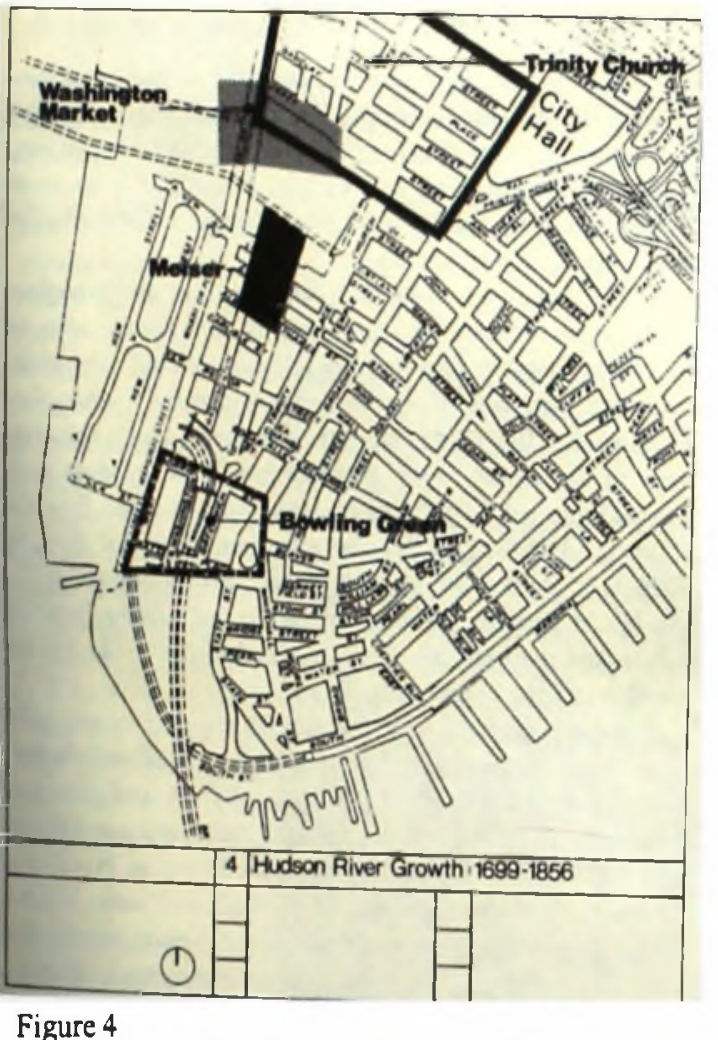

Figure 4
Yet, all was not lost. Although merchant trade and shipping were changing, new businesses found the waterfront advantageous. Renewed interest in the deep water dockage available along the Hudson River (refer to figure 4) made this the favored area for the new cruise ships, whose lines built terminals on Manhattan's 'new' West Side. Enough complaints about the conditions of the docks and piers, the terrible odors, the squalid garbage-laden water, and the damaged bulkheads led to the creation of several commissions and committees. The Docks Commission and the New York Harbor Commission helped to reshape Manhattan's waterfront and recommended permanent pier and bulkhead lines. Along with the desires to clean-up the waterfront and maintain clear waterways at the urging of the shipping and passenger lines, the Harbor Commission also established "the State Pier and Bulkhead Lines, beyond which no further construction could take place". 13 This creation of new piers and bulkheads also helped the city to grow northward. The new steam powered railways, likewise, aided this growth. With improved public transportation, new areas of the city became accessible. One's social status and place of residence were linked to income, occupation, and ethnicity. With more areas of the city opening-up and expanding Manhattan northward, greater housing choices developed Following this, "[t]he sad condition of dwellings, the polluted water supply, public health crises, increasing crime, and inadequate schools were the most obvious of the matters that received attention," as the new people arrived. ${ }^{14}$ 


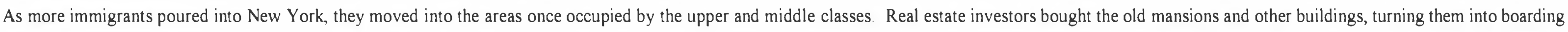

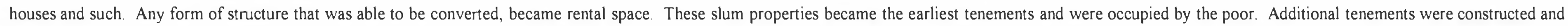

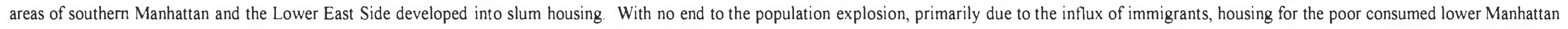

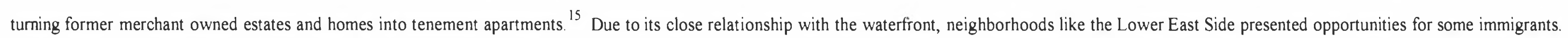

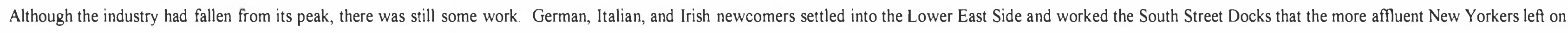

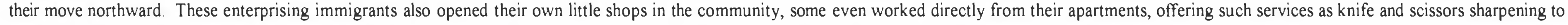
seamstress and dress-making.

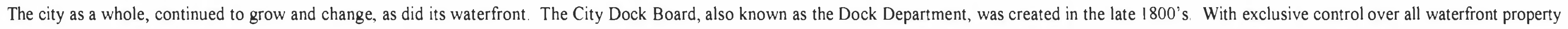

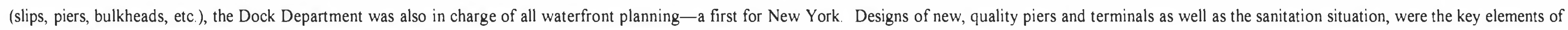

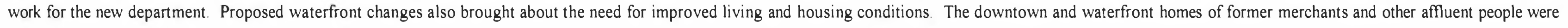

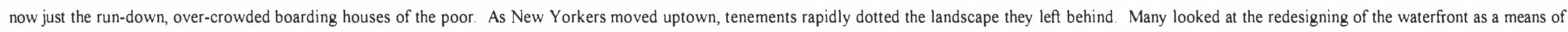

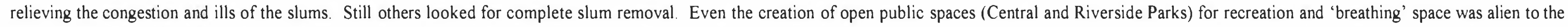
waterfront, since the entire waterfront was to be used for commerce (refer to figure 5). ${ }^{16}$

\section{Figure 5 :}

Typical waterfront activity along New York. Goods lying about, mostly unprotected, vessels jammed into the docks, and neither open nor recreational spaces.

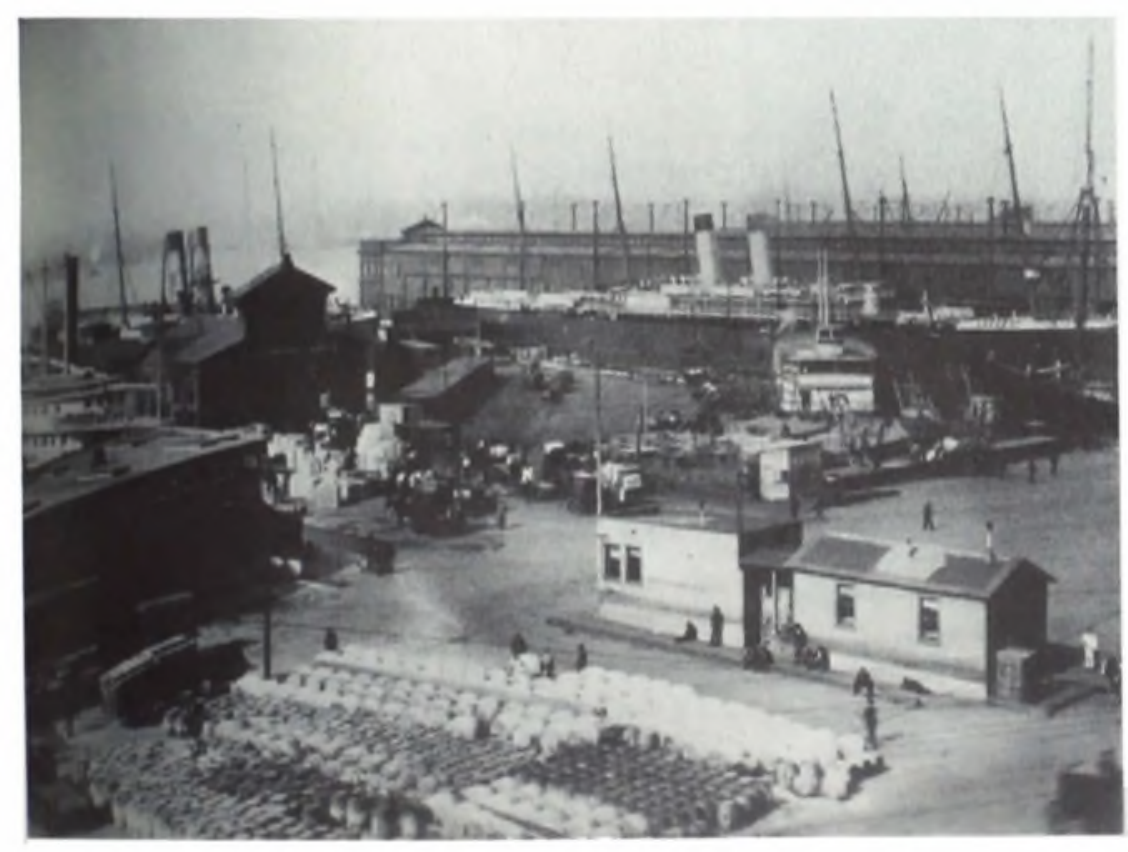

While all the planning and designing led to ambitious strategies, little was actually constructed. In reality, New York's waterfront had fewer piers due to the demolition during the new bulkhead creation. As New Yorkers and their activities pressed further north, the few piers in the Chelsea area were filled with commotion. Yet the liners and trade ships still preferred the South Street dockage in the East River instead of traveling up the Hudson River. New plans for areas of Chelsea were meant to attract the passenger liners. However, future planning clashed with the then current reality-bigger and longer ships were constantly being introduced and the just under construction facilities were not large enough, and hence, obsolete before they could be used. Proposed 1903 plans for one thousand-foot piers at Chelsea met with opposition from the Dock Department on excavating the filled land since it would increase traffic congestion. Extending the piers further into the Hudson was rejected by the War Department, which feared the longer piers would narrow the river too much 
Its charge was to gather in one place the most practical of the piecemail proposals for the betterment of the city and to form them into a unified plan. Included were schemes for bridges, parks, widened thoroughfares, and civic centers. For the Chelsea waterfont, the "New York City Improvement Plan" was a well-timed public relations document ...the commission cited the Chelsea improvement as an example of "a unified design and construction" that would create "harmony and symmetry" and a "waterfont with an architectural appearance worthy of the city".

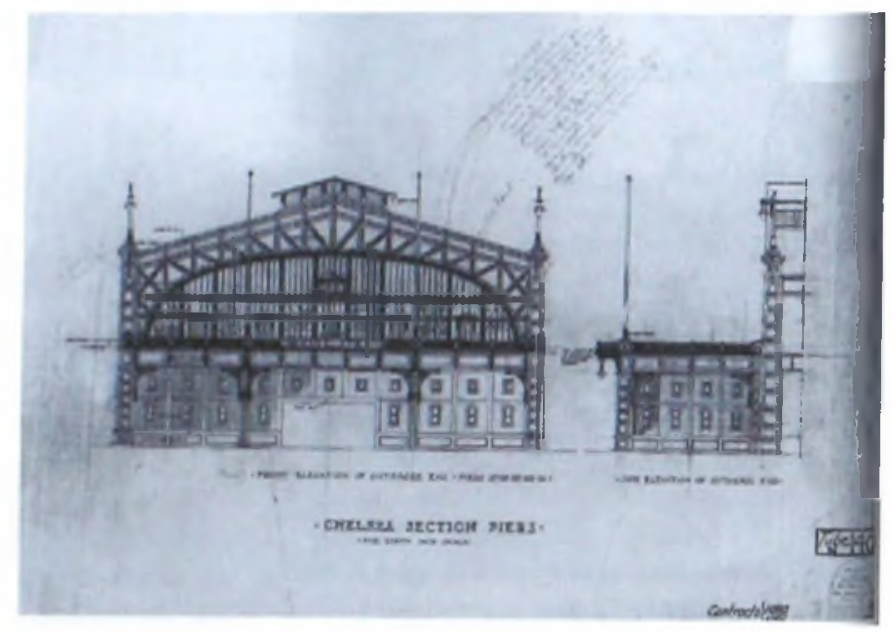

Figure 6

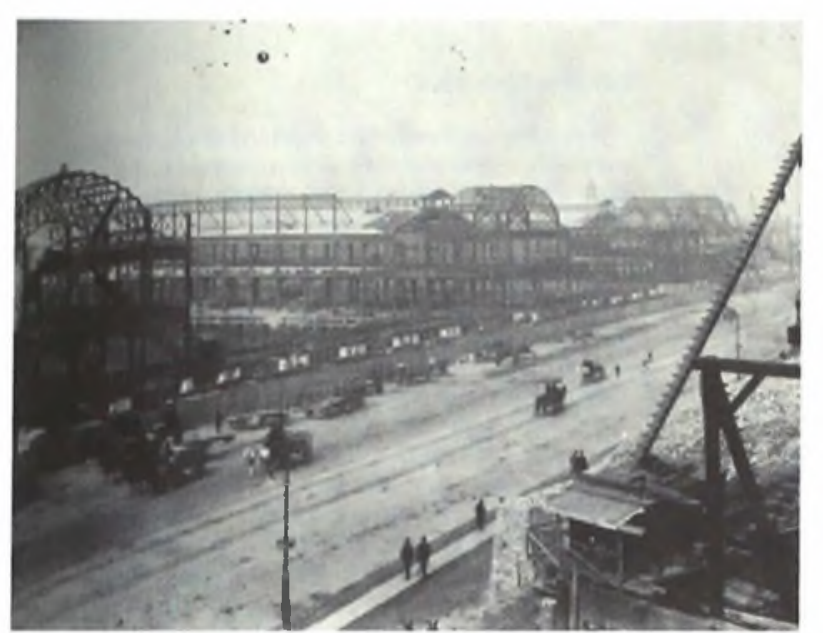

Figure 7:Photo of Chelsea Piers construction

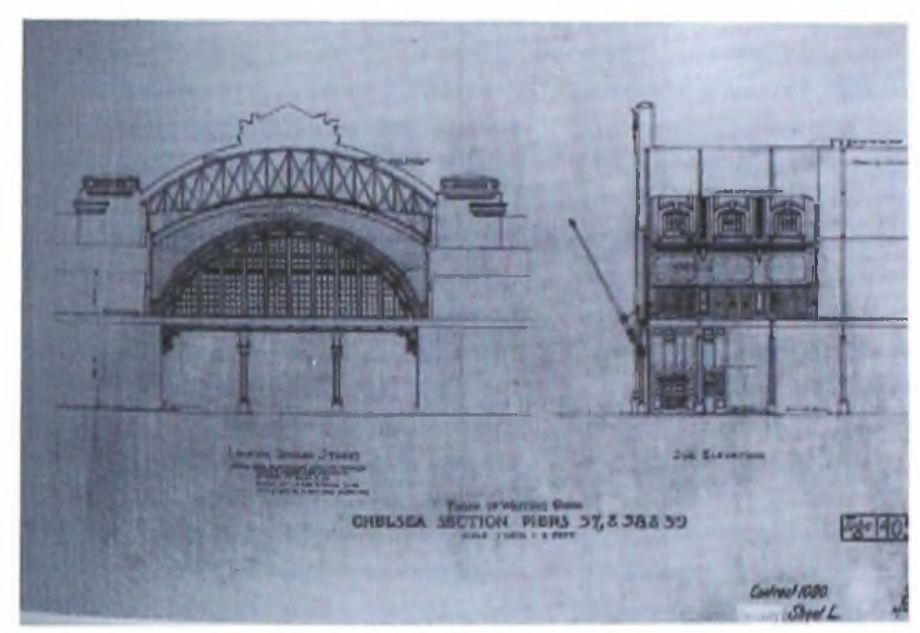

Figure 8

While many parts of the Mayor's plan were put aside, the Chelsea project was a success. Figures six and eight (above) detail the elevation and sections of the piers, while the photo (c. 1909) shows the piers under construction. Fortunately, neither financial nor legal predicaments would force the project's abandonment. Instead, subsequent decades would find the Chelsea Piers home to the 'queens of the sea'. The Chelsea project made an area of the waterfront more hospitable for a select few, showcasing both public pride and civic enhancement in the early twentieth century ${ }^{19}$ Chelsea would become home to the Cunard line, with such notables as the Lusitania and later the Queen Elizabeth 2. Over the years, other cruise lines would make the Chelsea piers their boarding point. 
Figurc 9:

Vicu of Manlattan from Brooklyn during the Brooklun Bridgc.

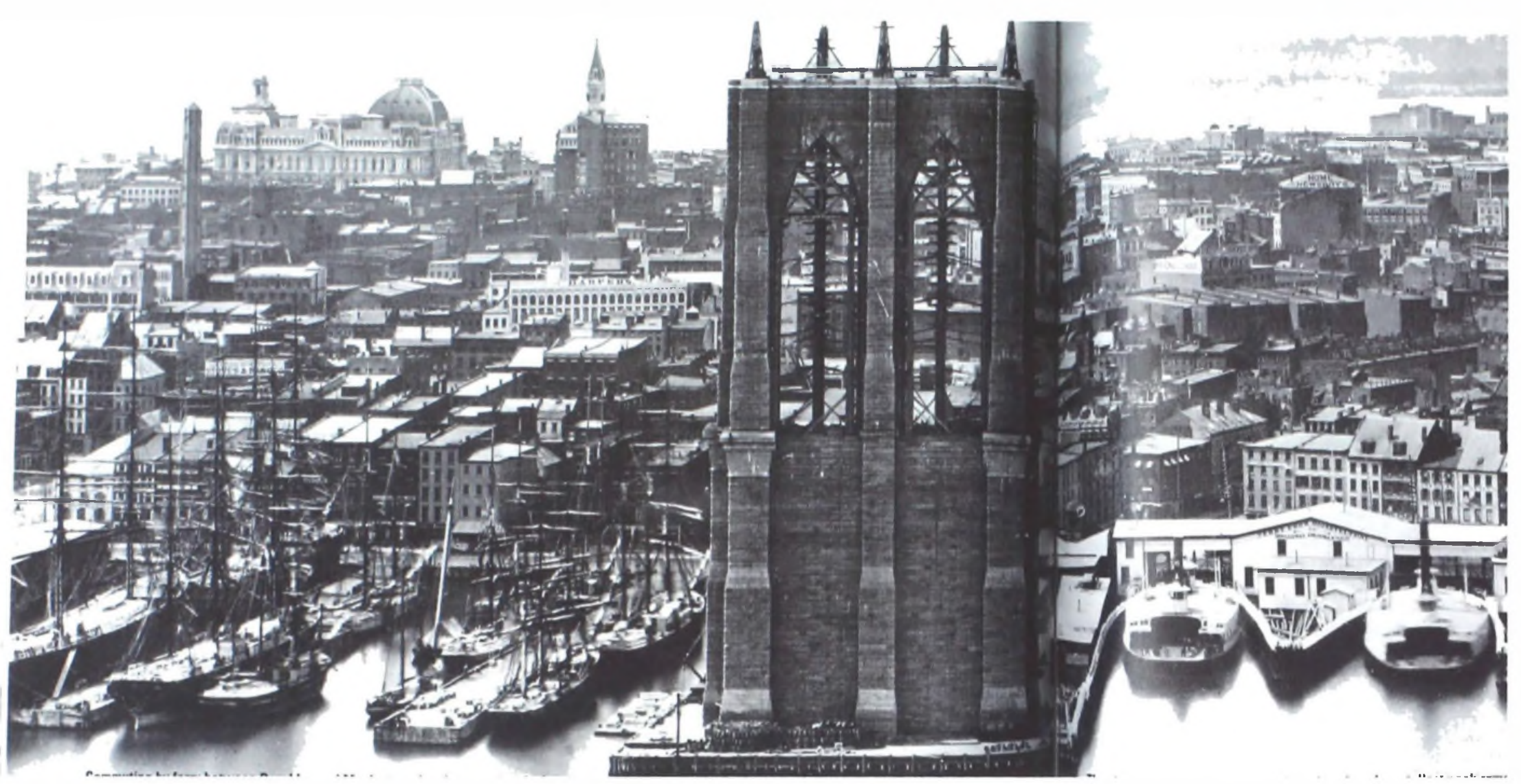

Decline of New York's Waterfront

A series of events that would forever change New York, and ultimately its waterfront, took place during the late $19^{\text {th }}$ Century to early $20^{\text {th }}$ Century. First, the railways crossed the rivers to Grand Central and Penn Stations. The rail industry would lead to first the elevated trains ("els") and later to the (now) infamous subway system. Building and bridge construction, like that in figure nine, marked Manhattan's entry into what would become the "skyscraper craze". Immigration increased, as did congestion. The invention of the automobile would not only add to the traffic but also change how roadways would be conceived and built. This was a point in history that would change the face of New York's waterfront, especially in areas like the Lower East Side

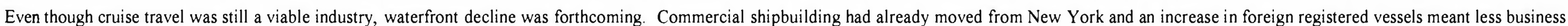

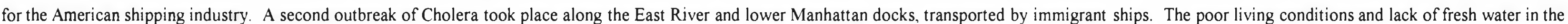

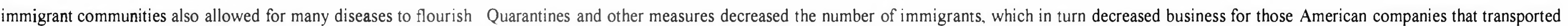




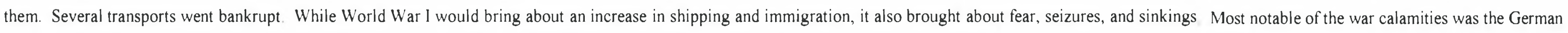

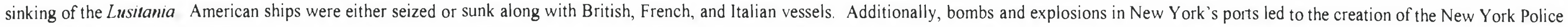
Department Bomb Squad. A German terrorist ring was ultimately found responsible for manufacturing bombs and attaching them to ship's rudders as they sat 'safely' docked.

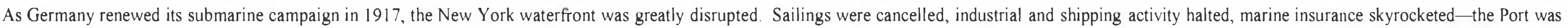

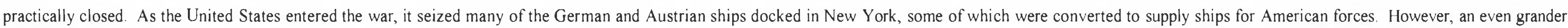
event took place in order for war preparation. "Shipbuilding was put on a mass-production basis; one of the largest shipyards in the country was in the New York area",20)

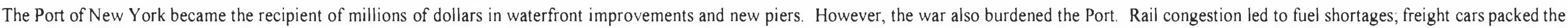

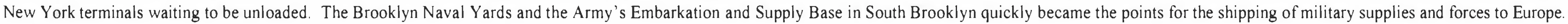

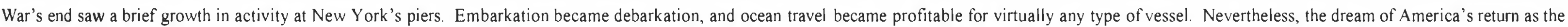

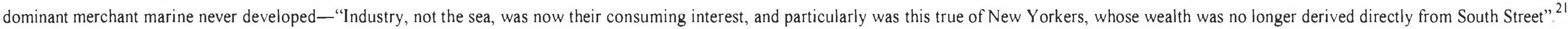
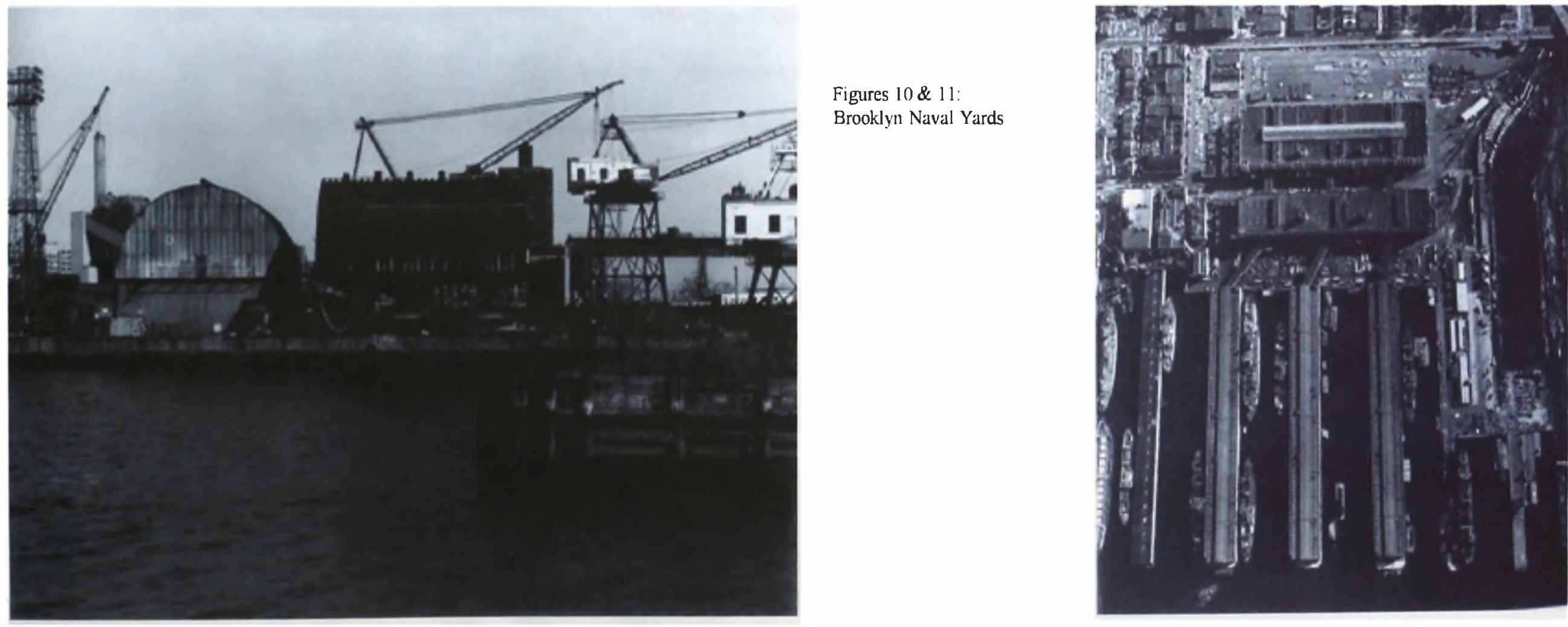
Ironically, World War II would be a repeat for the New York waterfront. The passenger terminals on the Hudson River nestled the world's greatest passenger ships-Queen Mary and Queen Elizabeth of Britain,

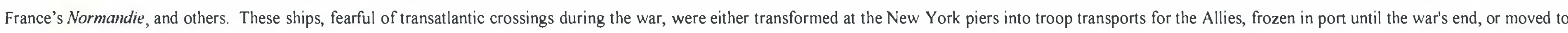

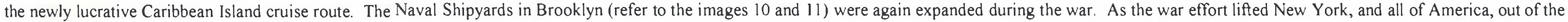

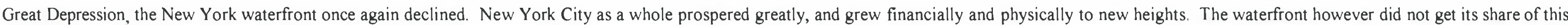
prosperity.

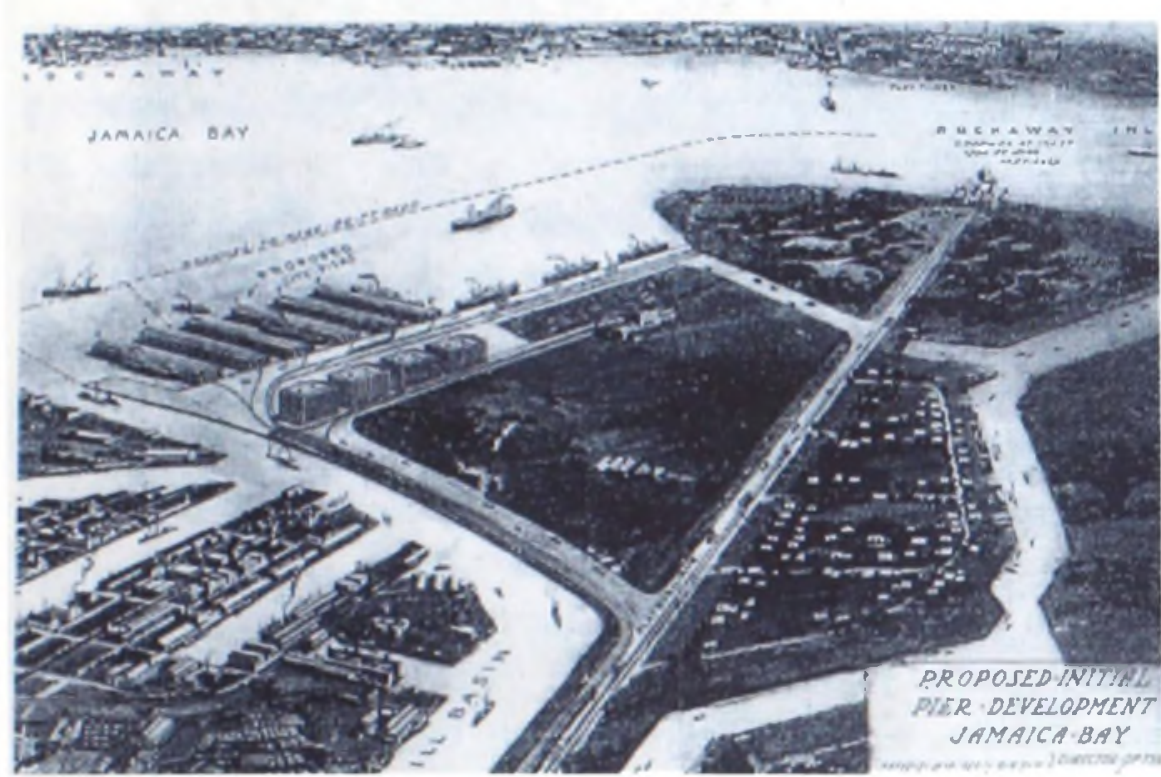

Figure 12: Jamaica Bay

During the 1920's, the Dock Department began a modernization plan for New York's waterfront including the outer boroughs. Modern piers with new rail and mechanical devices were constructed during projects in Brooklyn, Queens, and Staten Island. The proposal at left was for Jamaica Bay. From this point in time through to the end of the Robert Moses era [addressed later], Manhattan's waterfront would lose vessel traffic to the surrounding areas. With the Dock Department creating eligible dockage throughout New York, the Upper East River of Manhattan was then lined with hospitals and apartment complexes. The Chelsea Piers and a few other transatlantic piers blocked the Hudson River, making the Northern Hudson waterfront inaccessible to trade ${ }^{22}$

With complaints blossoming from the New Jersey side of the Hudson, a bi-state agency was formed—the Port of New York Authority. Also known as the Port Authority, it was assembled to ease the static between New York and New Jersey, and therefore

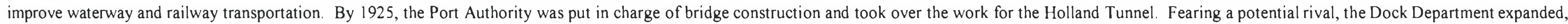

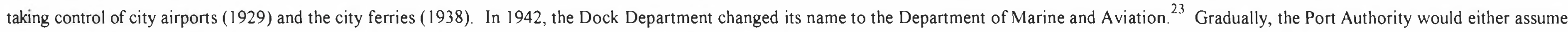

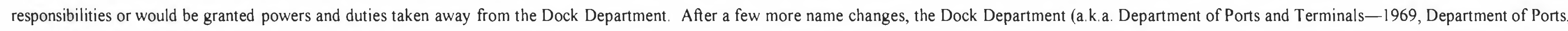

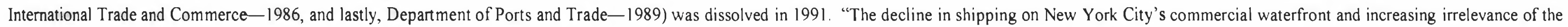
department in the development and implementation of waterfront plans made it superfluous... its remaining waterfront duties were assigned to the Port Authority. ${ }^{24}$ 


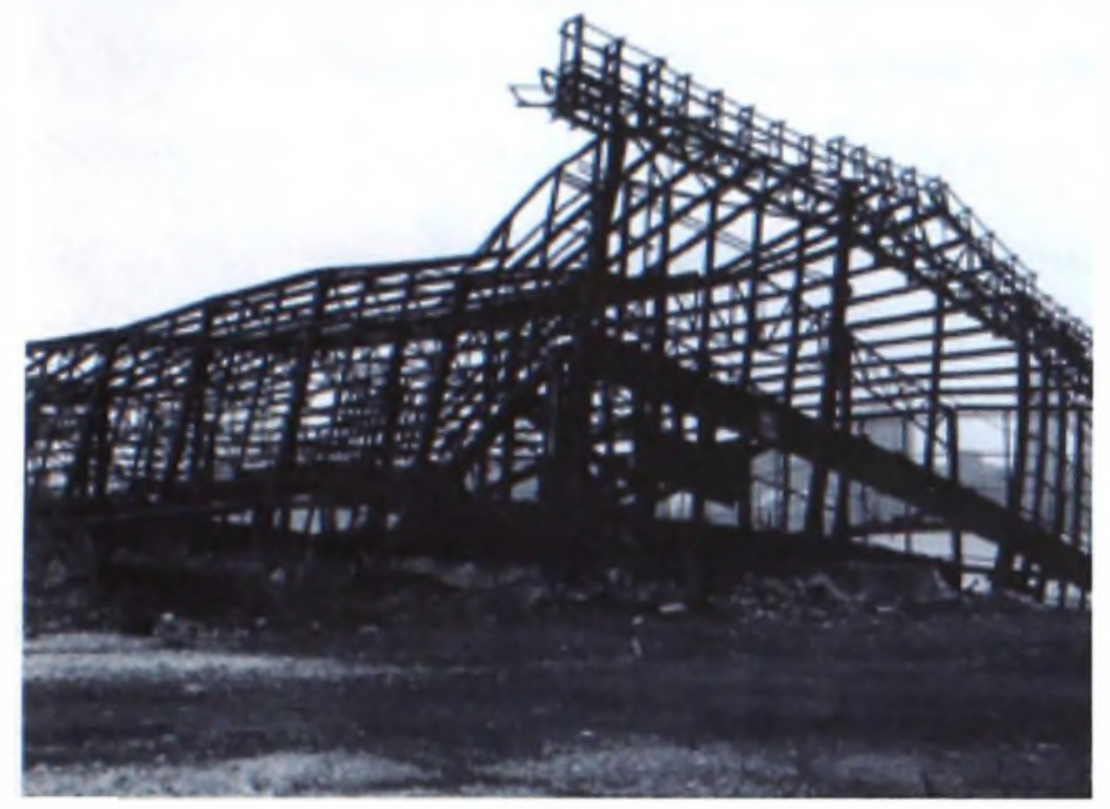

Figure 13

Figure 14

off of Manhattan.

Currell walerfroml condiluons found along the once thriving docks off of Brooklyn.

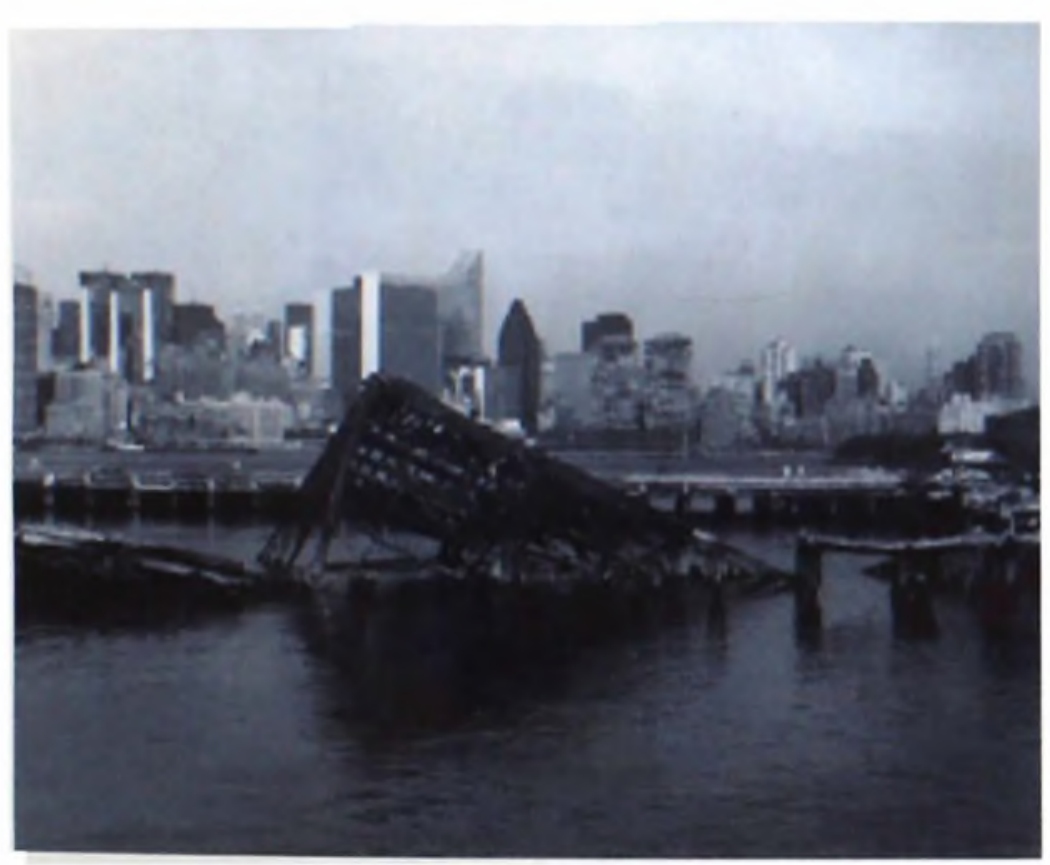

The Department of Docks can be credited with ultimately shaping the waterfront of New York City, in spite of the lack of a visible physical legacy (note figures 13-16). The department's work is said to still effect today's metropolitan environment. The department's ability to plan and implement is accredited to individual vision and will, with commitment to the plan being derived solely from its promotion of the waterfront's commercial potential. "The quantity of stereographs and postcards depicting New York City's cargo-laden piers and waterfront streets suggests that the public shared his belief in maximizing the economic viability of this area."25 In the end, when commercial shipping in Manhattan collapsed, the plan was doomed to fail.

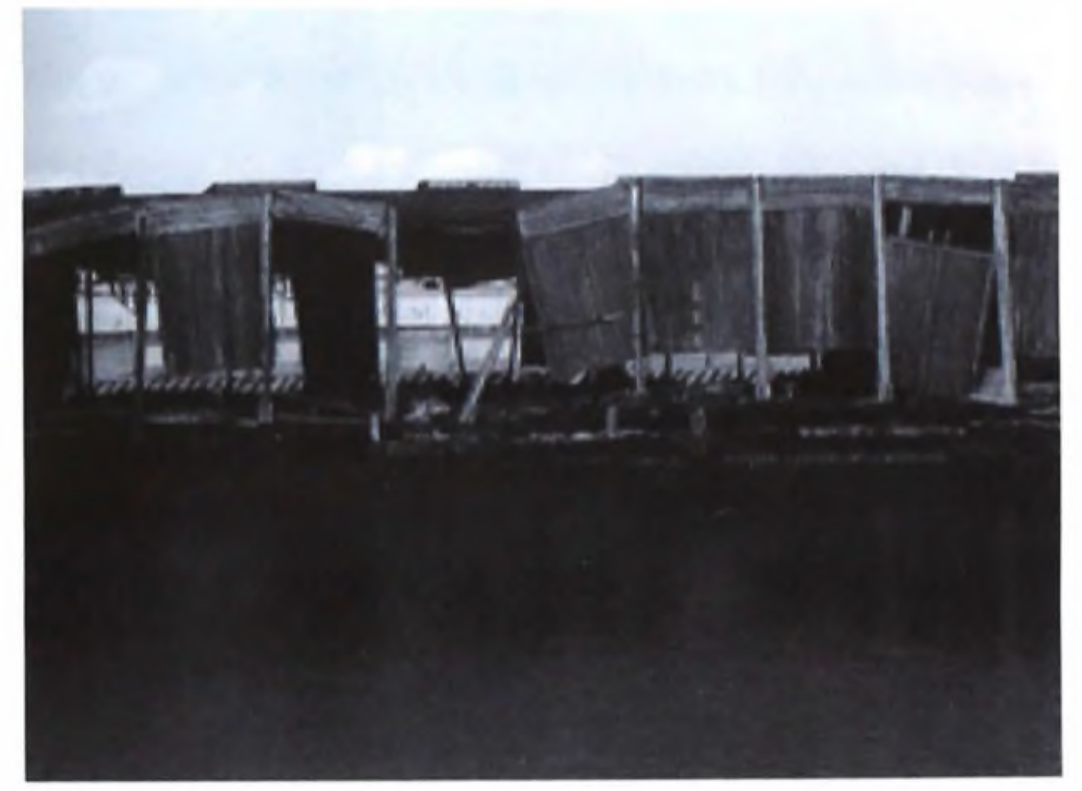




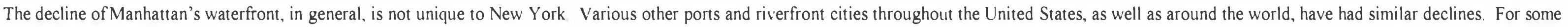

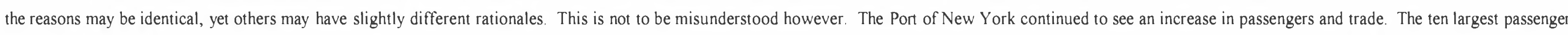

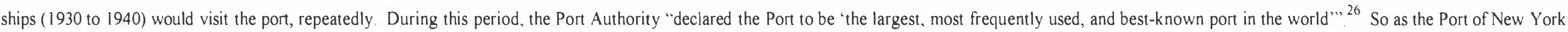

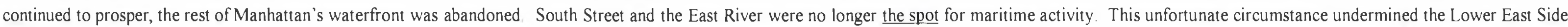

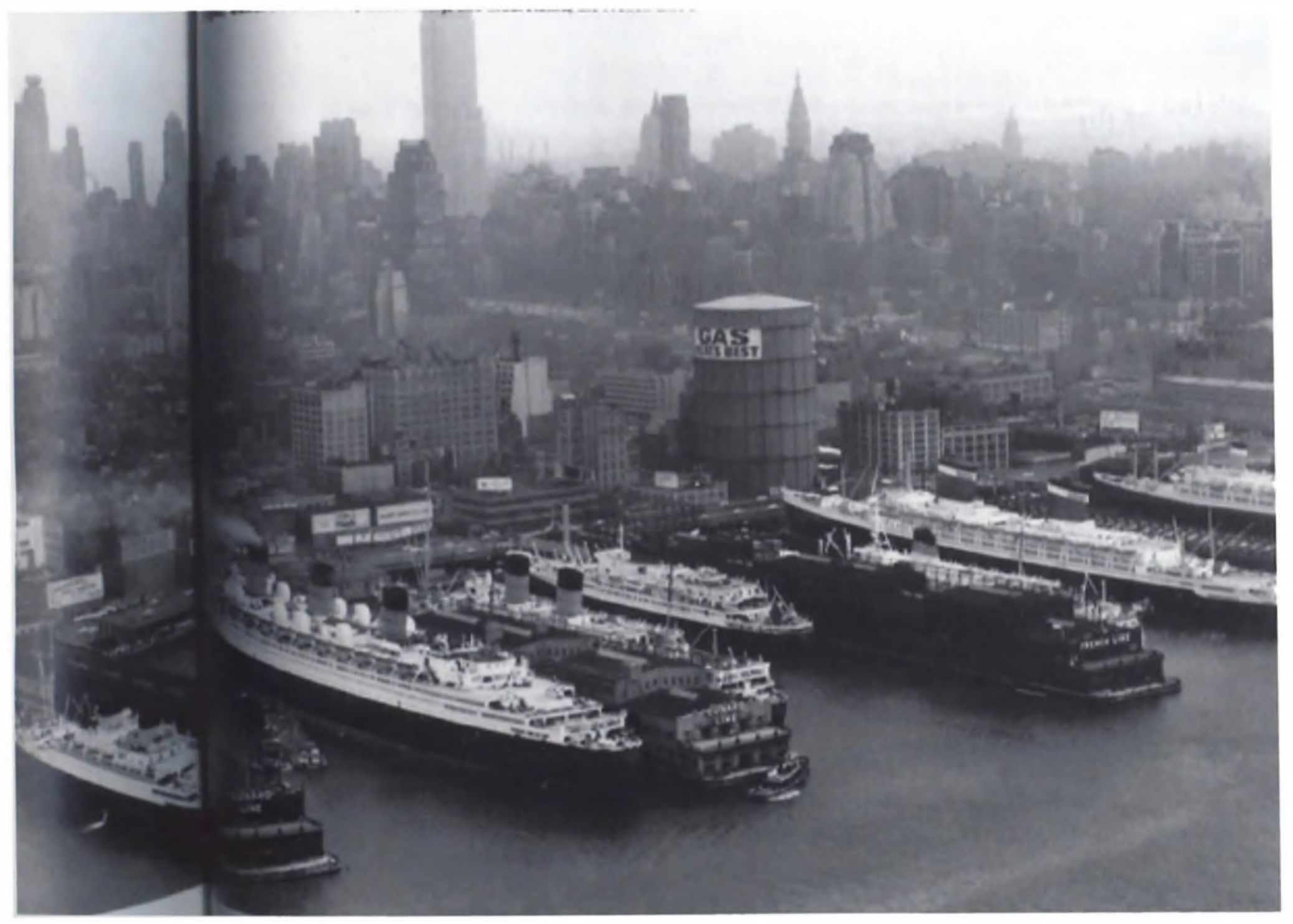
community, which quickly became a slum. The Hudson River was the home of the vast Port of New York. Figure 17 illustrates the busy Port in 1957, when seven of the world's greatest cruise ships docked side-by-side ${ }^{27}$ Cunard's big three (Britamic, Queen Mary, and Maurelania) were typical sights, joined by vessels from France and Greece. With the development of transoceanic commercial jet travel, this era of cruise lines would end and within "three decades, only a single ship-Cunard's Qween Elizabeth 2-would be making regular crossings" ${ }^{28}$ Air travel grew rapidly. Though the Port of New York remains one of the largest ports in the world, air travel helped decrease its traffic, as it did throughout the globe. Additionally, cruise travel found the year-round warmth of the southern United States and the Caribbean to be more profitable. Maritime structures from seawalls and basins to docks and wharves occupied practically every inch of the city's shore. During the Port's prime, the riverfronts witnessed the construction of thousands of harbor structures. Ironically, as "the city and the water met along an intricate, many-layered edge," the vertical gave way to the horizontal-a long, low city of railroad buildings, headhouses, industrial facilities, shanties, bars, and whorehouses. This urban world was in and of itself a portal between the water and the metropolis. ${ }^{29}$

Figure 17 


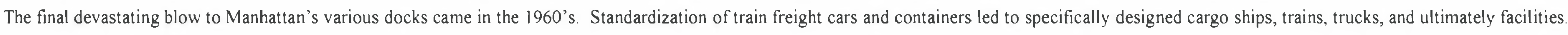

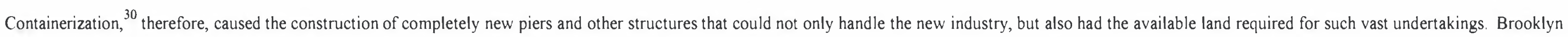

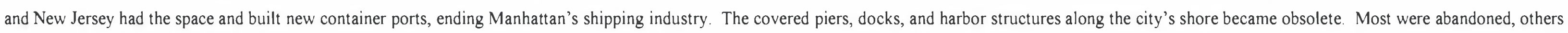
demolished, yet some were later replaced by redevelopment. ${ }^{31}$

\section{Waterfiont Rejuvenation in the Late $20^{\text {dh }}$ Century-South Street Seaport}

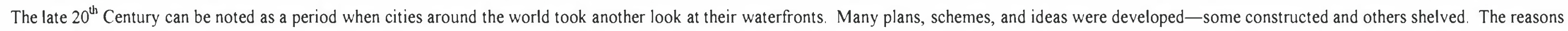

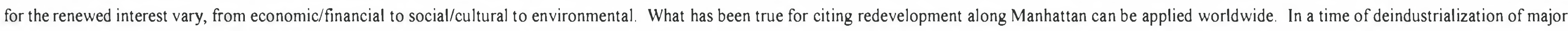

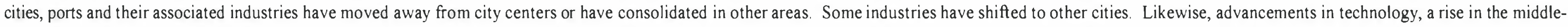

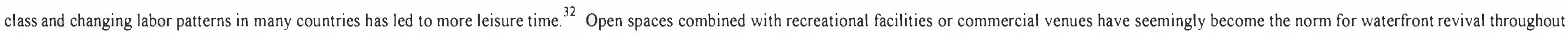
America

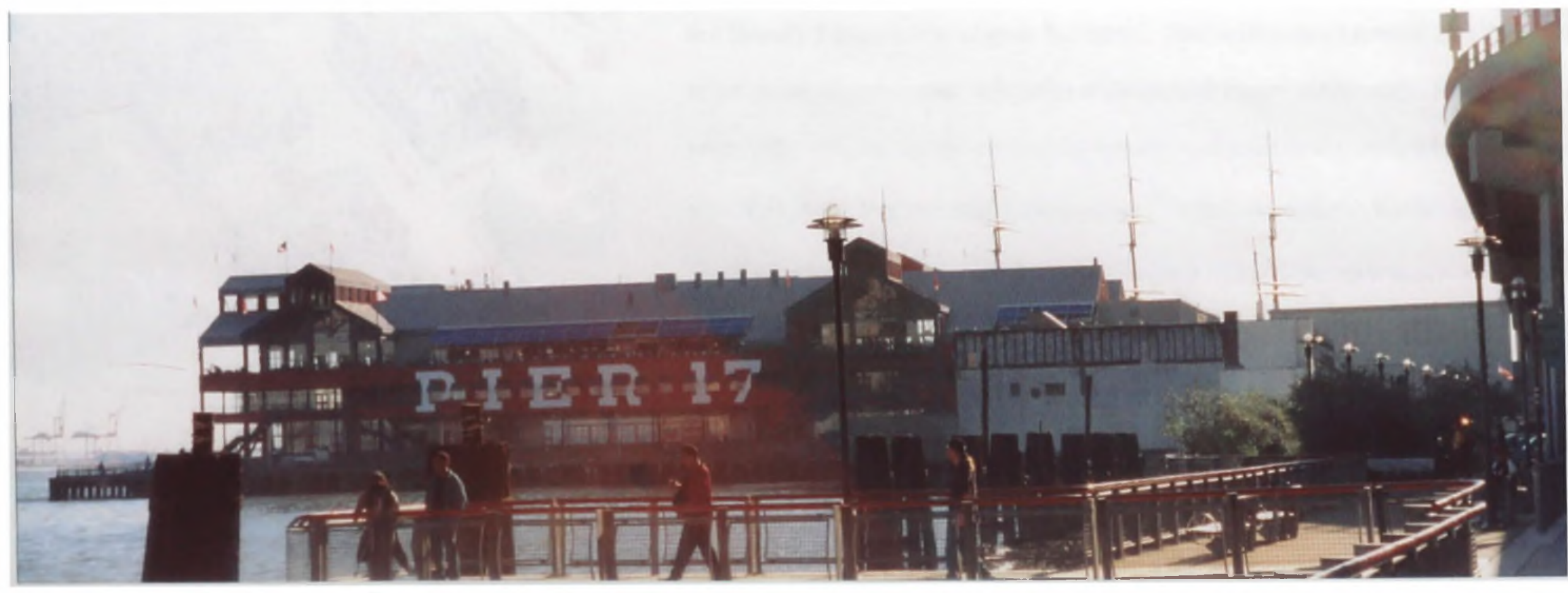

Figure 18: Pier 17. South Street Seapon 


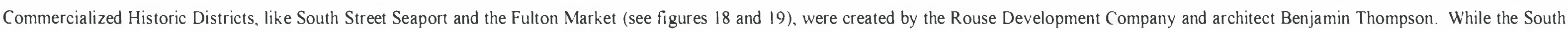

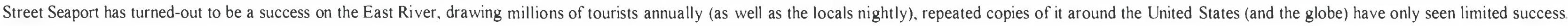

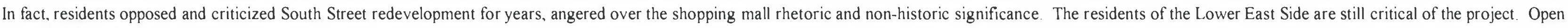

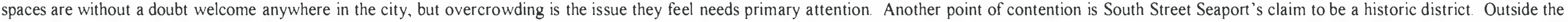

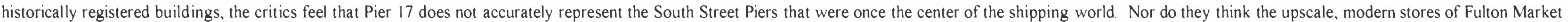

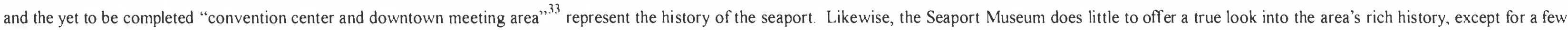

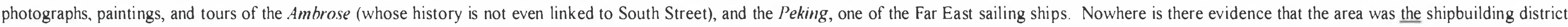
during the $18^{1 / 1}$ Century. ${ }^{34}$ However, the added pedestrian path and bike esplanade along the river, plus the spectacle of the

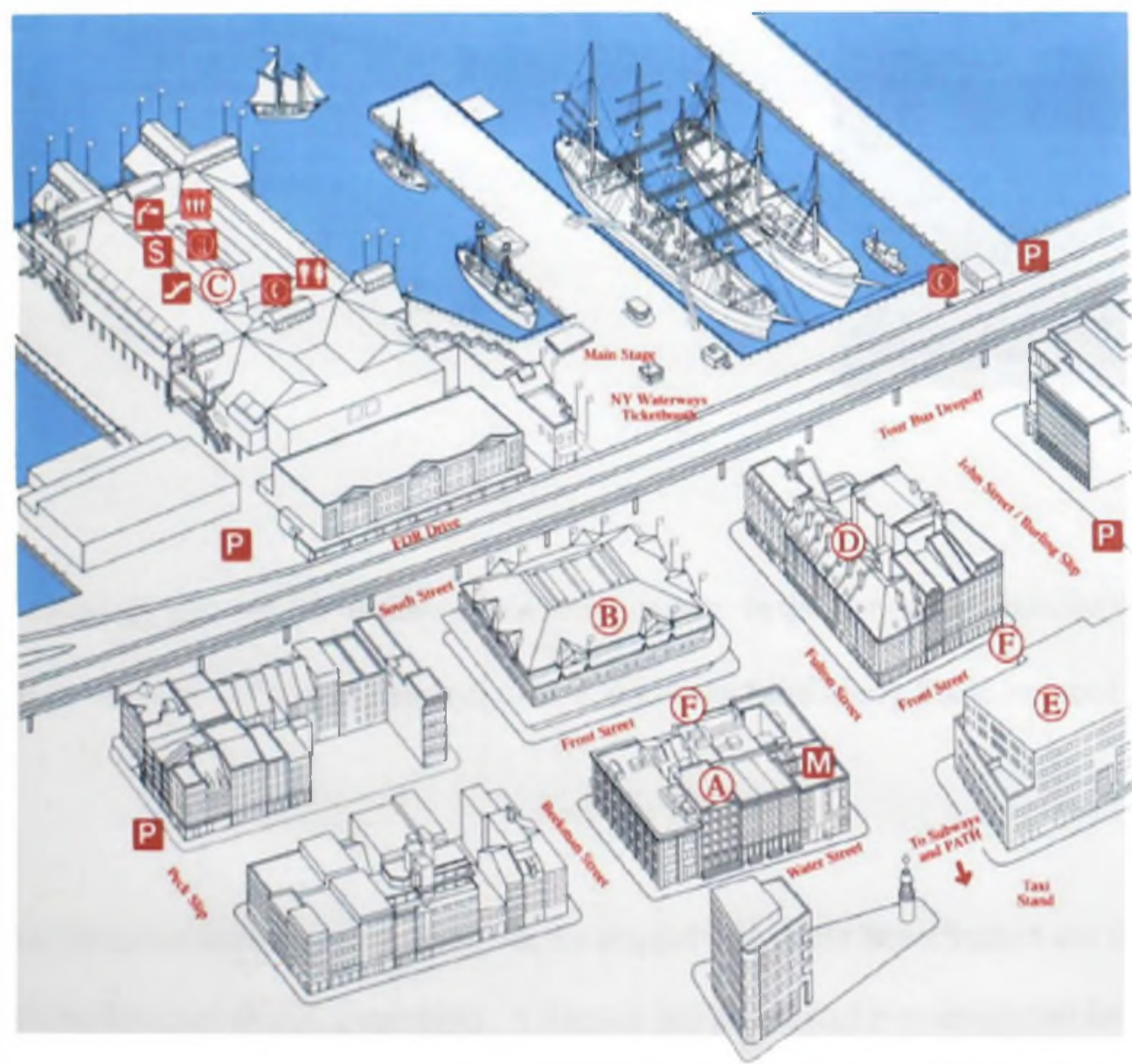
Brooklyn Bridge, have changed some opinions (as have the tourist dollars). Both sides of the argument are in agreement that the 1997 addition of the East River Bikeway and Esplanade is an important and exciting link. From Pier A in the Battery around the Wall Street and South Street Piers, the path skirts the Lower East Side, then continues northward through the East River Park and extends to $125^{\text {th }}$ Street in East Harlem.

Supporters of the Rouse project view the Seaport and Fulton Market as a major success, bringing in tourist money to a formally depressed area of lower Manhattan. The question then becomes, does that money stay within the community or get passed-on to the parent companies of the up-scale shops? Additionally, New Yorkers are more concerned with inland improvements, interior commercial districts, residential blocks, and public spaces making the task of reclaiming New York City's forgotten edge a daunting one. ${ }^{35}$ The Comprehensive Waterfront Plan of 1993, the first city-wide shoreline proposal, mandated public spaces and direct access to the water in new waterfront developments (i.e. figure $20)^{36}$ While large scale projects typically went unbuilt, smaller ones were developed 


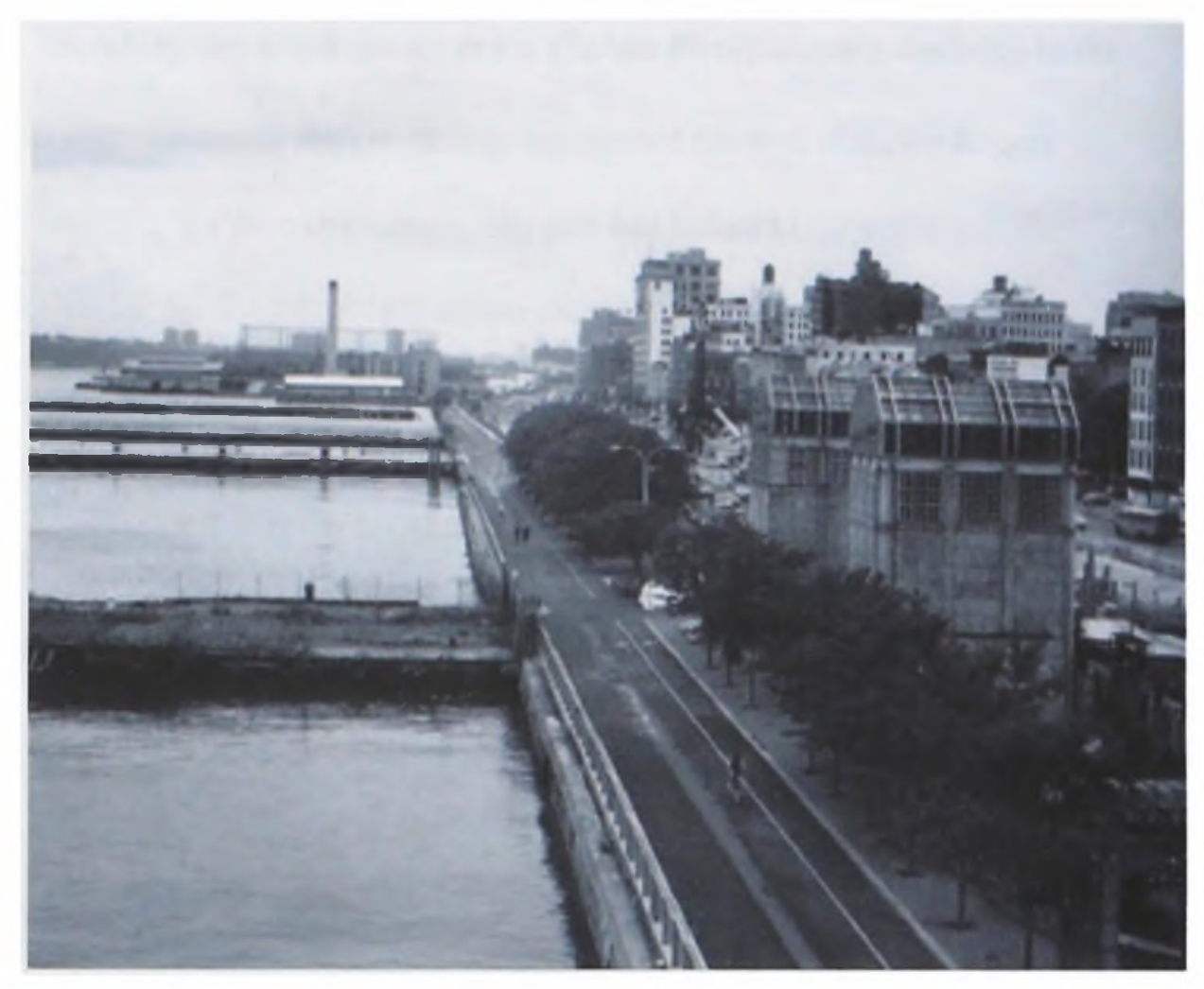

Figure 20: Along the Hudson River

Surprisingly ferry service has also seen a rebirth of late. In the glory days before the tunnels and bridges, one hundred twenty-five ferry lines operated along the Hudson River, the East River, and New York Harbor. By the late 1960s/early 1970s, only one ferry service, the Staten Island Ferry, could be found on New York's waters. ${ }^{37}$ Today not only ferries motor along the Hudson and East Rivers, but also sightseeing and dinner cruise ships.

Manhattan's waterfront reinvestment has not stopped with South Street Seaport and the New York ferries. The Chelsea Piers have developed a strategy that is more sports and entertainment and less historic commercialization (read shopping complex). A formula that has worked in a city starved for sporting venues, the piers provide an amenity that the residents of New York can use and are a way of reconnecting them to the waterfront. Figure 21 shows the expansive complex that occupies the same piers that were home to the Cunard line and the transatlantic 'queens' (note the Golf Club pier in the distance of figure 20). Waterfront renewal seems to have a common underlying theme-one's desire to spend time along the water. Whether actively engaging the water or content to be along its edge, urban pleasure seekers will gravitate toward whatever body of water they live near, regardless of barriers and limitations. ${ }^{38}$ Although the grand and architecturally interesting projects garner more attention, the biggest change among the urban waterfront currently is the creation of public 
As James Rogers cites in a recent publication on their work, Butler Rogers Baskett was tasked with creating a sports and entertainment complex that would bring vibrancy to the life of New York City ${ }^{39}$ The interesting status and history of the Chelsea Piers became a challenge to the architects as well as the partnership (Chelsea Piers LP) that purchased the site. Originally the partnership approached the firm of Butler Rogers Baskett with the idea of developing a new ice-skating rink and facility at pier 61 . To their amazement, that pier was linked to the entire complex (see figure 22) and the owner, the State of New York, would only rent the entire complex to private parties and only via a public auction. With luck, or maybe fate, the partnership won the site at auction and therefore set into motion the development of recreational facilities that focused more on the needs of children and young adults. In four short, fast-paced years, the architects developed the Chelsea Piers Sports and Entertainment Complex, as depicted in figure 23. This project, unlike any other to date, has "restored confidence in the viable success of commercial development of outdated, abandoned urban infrastructures, and has directly influenced the formation of other such projects" ${ }^{40}$ [Refer to Appendix A for additional project information.

\section{CHELSEA PIERS!}

\section{A 30-ACRE SPORTS VILLAGE}

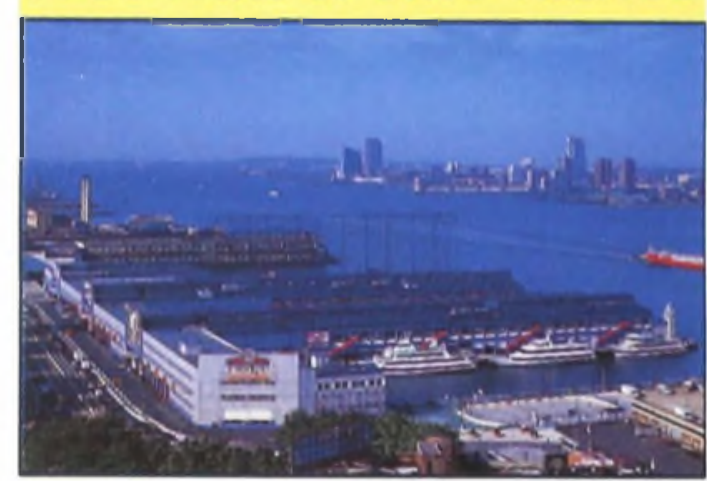

Figure 21: Chelsca Piers

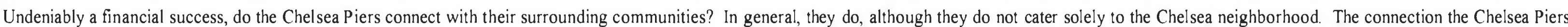

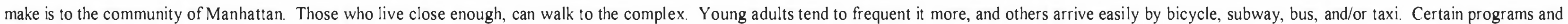

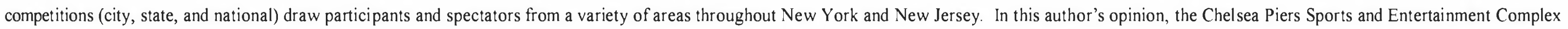

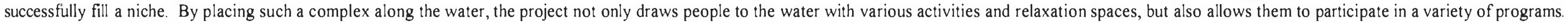

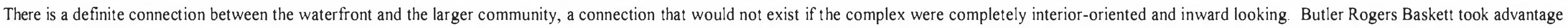
of the location while developing this project 


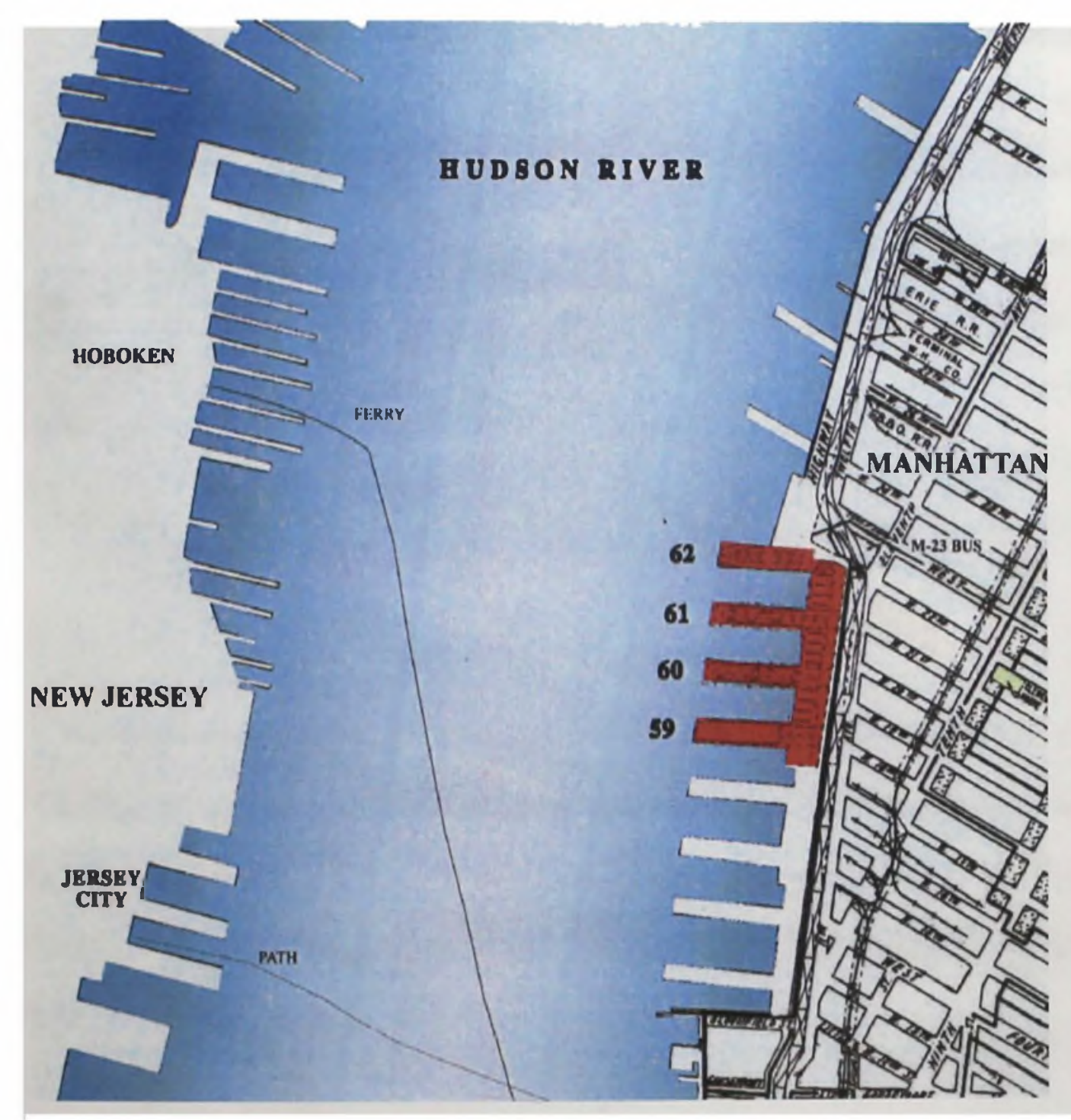

Figure 22: The Chelsea Piers

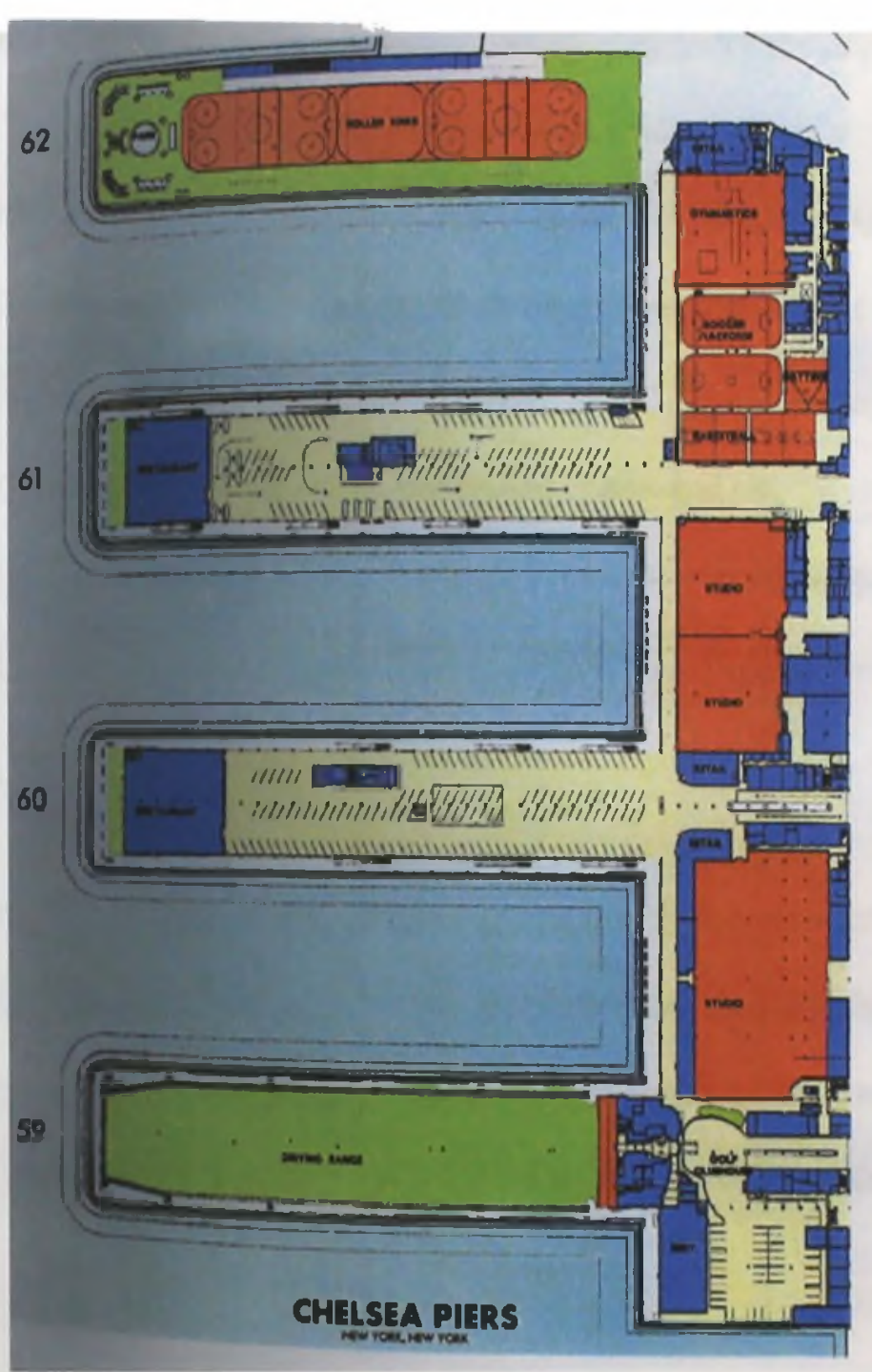

62

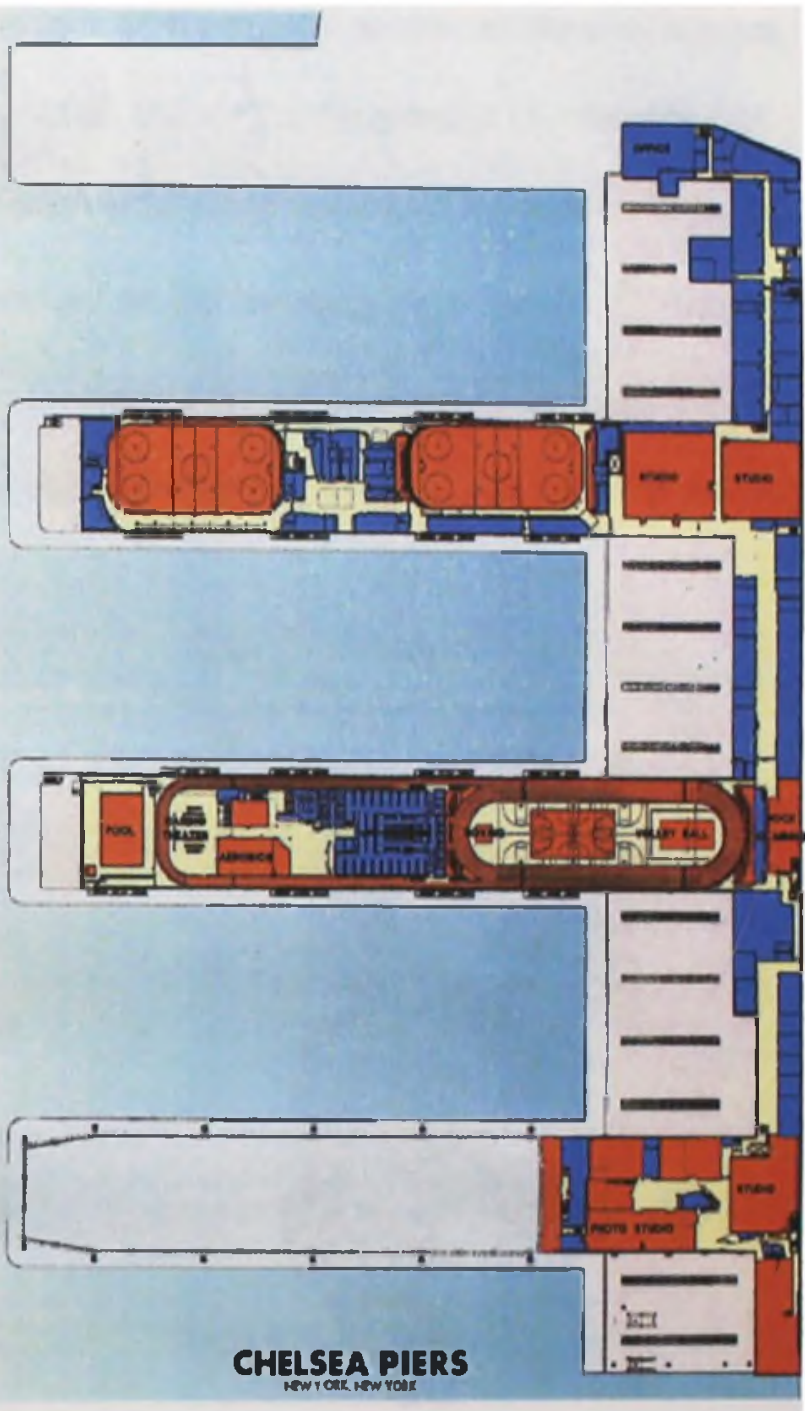

Figure 23: Plans of the Chelsea Piers Sports and Entertainment Complex. 


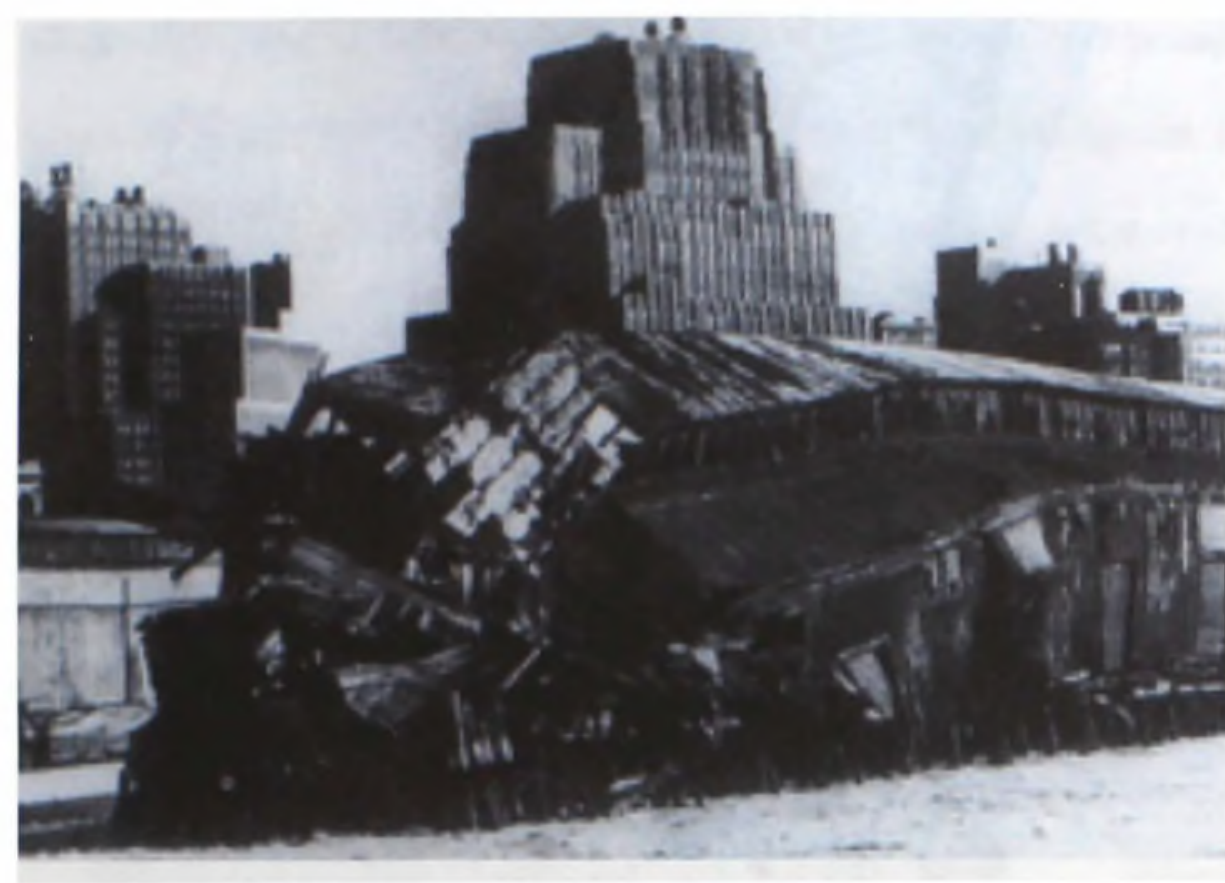

Figure 24: Derelict Whar
Between South Street Seaport and the Chelsea Piers Complex lies Battery Park City. The derelict wharves and piersheds (like figure 24) owned by the city would become part of an urban renewal and the last of the mass landfills on Manhattan's waterfront. The landfill for Battery Park City was composed almost entirely of the excavated earth from the neighboring World Trade Center construction. Completed in 1976, the 92-acre parcel successfully extended the city's fabric and grid of streets and avenues onto the new land (see figure 25). What today seems like a conservative urban strategy, was in 1979 a radical move. "For the previous four decades, the redevelopment of cities had been influenced by the techniques of large-scale Modern architecture: superblocks, separation of land uses, elevated streets and building designs which aggressively proclaimed their difference from the historic fabric of the city " 41 The eight design principles (see Appendix B) for Battery Park City were the key elements for keeping the community connected with its waterfront. Despite this successful integration of new and old, "West Street, an eight-lane highway on the landfill's eastern border, remains a barrier separating the new complex from the existing urban fabric." 42

Figure 2

Various plans and schemes were developed for Battery Park City. Some were even very ambitious (like the one in figure 26). The 1969 formation of the Battery Park City Authority (BPCA) oversaw the pier demolitions and landfill. The planned office buildings and luxury apartments would not occur as originally planned. The World Trade Center created a flood in the market for office space during a period that saw increasing unemployment and downsizing. The same applied to residential housing as the real estate market collapsed in the 1970's. The 1979 market turn-around brought about private investors, a new master plan (refer to Appendix B), and a revamped and somewhat privatized BPCA.

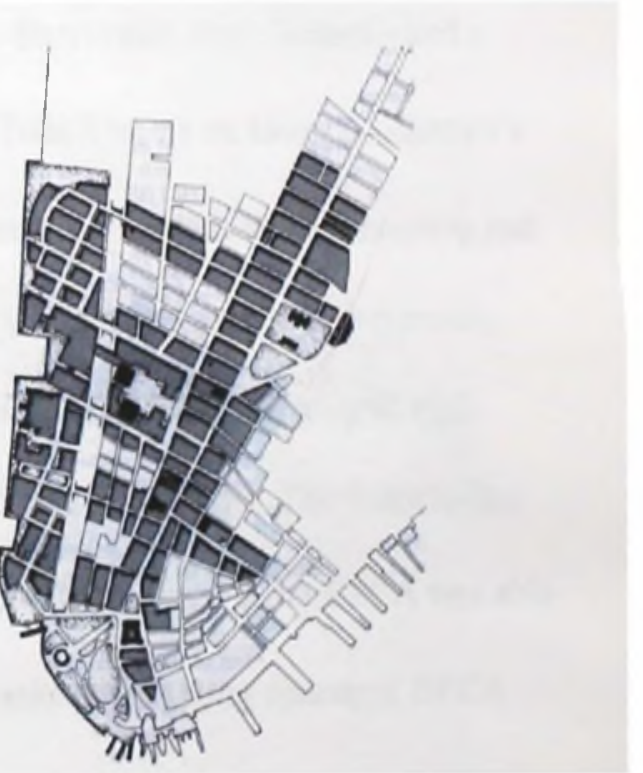


The earlier megastructure plans (like figure 26 above) were typical of the 1960's New City Rationale. The 36 blocks of the 1997 plan were easier to develop than the seven pods of the 1969 plan. In contrast, the streets, blocks, and parks of the 1997 plan were not only cheaper to build than a spine, but they were also simpler to understand and more public in nature than the grade separated pedestrian decks of the 1969 plan $^{43}$ Olympia \& York Developments of Toronto were brought in to oversee the entire office project. They in turn held a limited design competition between Kohn Pederson Fox, Mitchell Giurgola, and Cesar Pelli; with Pelli's scheme for the 'next Rockefeller Center' the winner. ${ }^{44}$ Depicted below in figure 27, Pelli's World Financial Center

Figure 27: World Financial Center as viewed from the top of the World Trade Center

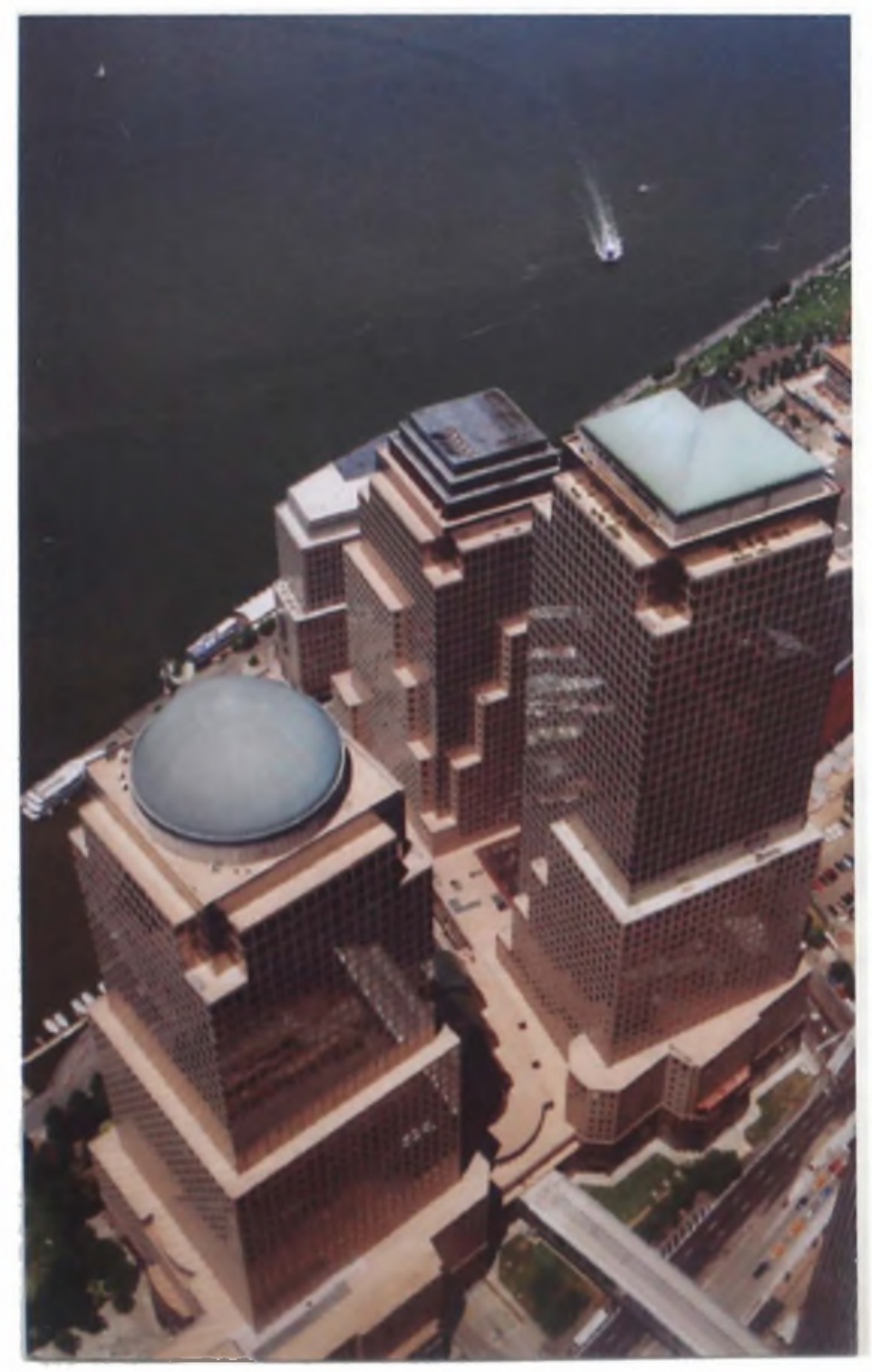

would attract the leaders in finance who would secure six million square feet by 1985 when the first tenants began to move in. The public Esplanade along the water and the enclosed Winter Garden (figure 29) that Pelli designed for his World Financial Center were the critical

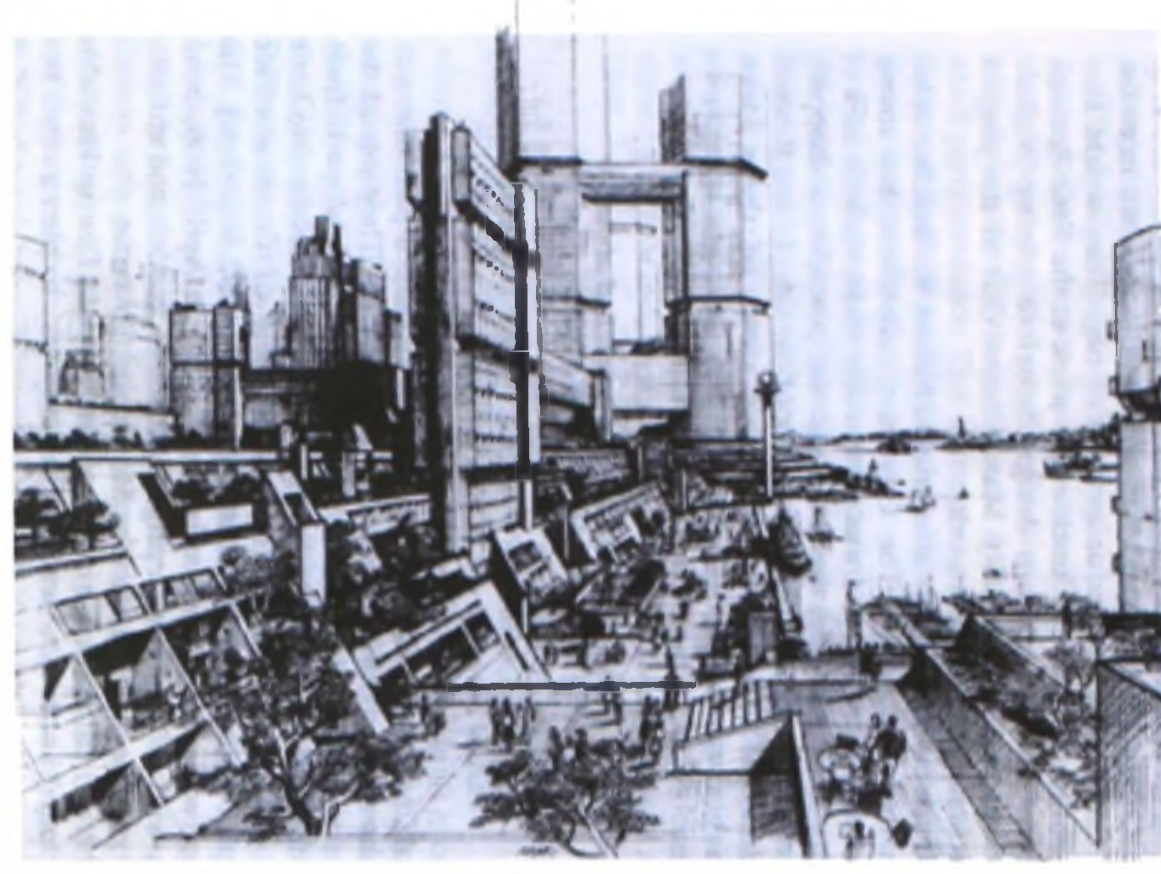

Figure 26: Battery Park City Scheme. circa 1969 and popular successes the project needed to continue, especially during an era that is known for its financial ups and downs (1980 to 1992). Surprisingly, BPCA continued their public and civic duties by adding one of New York's premier high schools-Stuyvesant High School—and a swimming pool, both on the north end of the site. ${ }^{45}$ While Pelli is credited with softening the dominance of the Twin Towers on lower Manhattan's skyline, the BPCA is credited with creating an inviting atmosphere with high quality public spaces and institutions. The middle-income housing and retail aspect were not as well received. The "ill-fated Pod IIl" was among the first residential buildings at Battery Park City, but the concrete box, shown in figure 28, was highly criticized. The project, called Gateway Plaza, was not public friendly in some minds. Originally developed eight years prior to construction by Lefrak and Fisher, residential developers, Pod III was typical of the 1960's megastructure rationale. The fortress-like design had a single guarded entrance and an upper level pedestrian deck that was separated from the access and service below. ${ }^{46}$ The BPCA was able to convince Lefrak to make certain design changes so as to fit into the new design guidelines. However, for the sake of financing concerns, BPCA gave in so that actual construction could take place

The second housing phase, Rector Place, was more successful publicly and as a residential neighborhood. Unfortunately, it was criticized tor having small, non-family oriented apartments. The third, Battery Place, was a nightmare. The stock market crash of 1987, the recession that followed, 


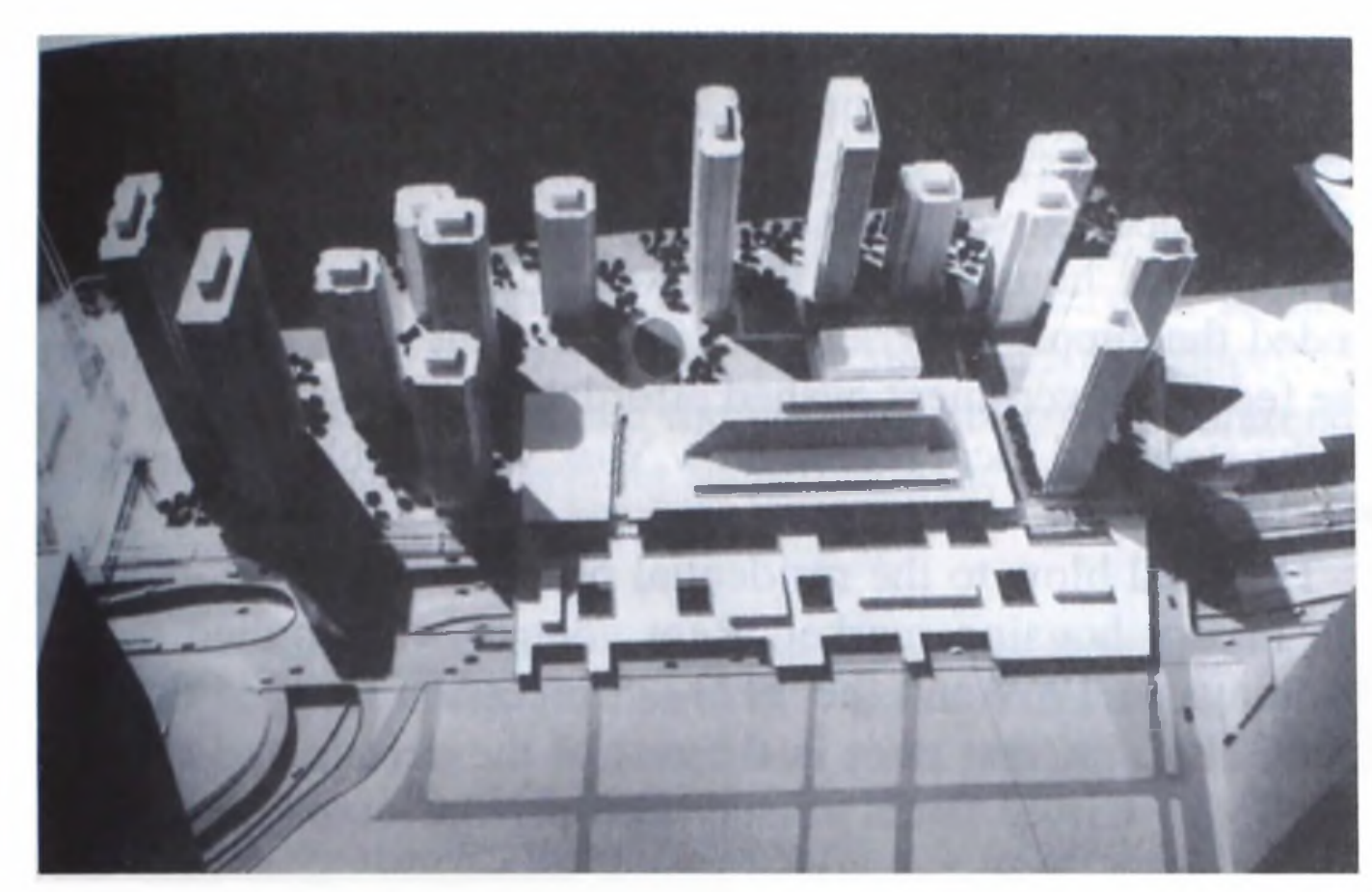

Figure 28:

Pod III by Lefrak and Fisher

and controversy over garden design doomed its development-forcing BPCA to start over and redesign that particular area. The final residential neighborhood started off on the wrong foot with only three completed buildings, but was praised after re-evaluation by the BPCA, who added an active public space, recreational facilities for children and better designed condominiums.

Figure 29:

The Winter Garden at the World

Financial Center. A glass enclosed

space with a tropical atmosphere.

Upscale shops and cafes catering to the

business professional can be found on

both sides and multiple levels of the

Winter Garden

The ups and downs of Battery Park City are part of New York City's varied history. As the "BPCA adopted a comprehensive strategy of changing the poor image of their waterfont site through high quality public spaces and institutions", and "maintaining these spaces at a standard far higher than the unfortunate norm" 47 While the public openly praises Battery Park City and supports that praise by "flocking to the esplanade and parks in droves," the critics regard the area as a non-New York space, where it is too clean, too stable, too safe, and does not reflect the urban chaos that is New York City. ${ }^{48}$ The critics continue to state that the public spaces are for rich white people. The public, who is outraged at such comments, has disputed both of these claims. The general public of New York asks if it is a crime to feel safe, or have clean open spaces. In addition, the parks are city owned and operated, and are open to (and used by) all types of people. Battery Park City has been able to create a neighborhood directly connected to its waterfront by its design and creation of the open and public spaces, especially the esplanade. Furthermore, it has connected the communities of Tribeca and the West Village to the waterfront in such a manner that they have been actively involved in the designs of the final vacant properties. 49

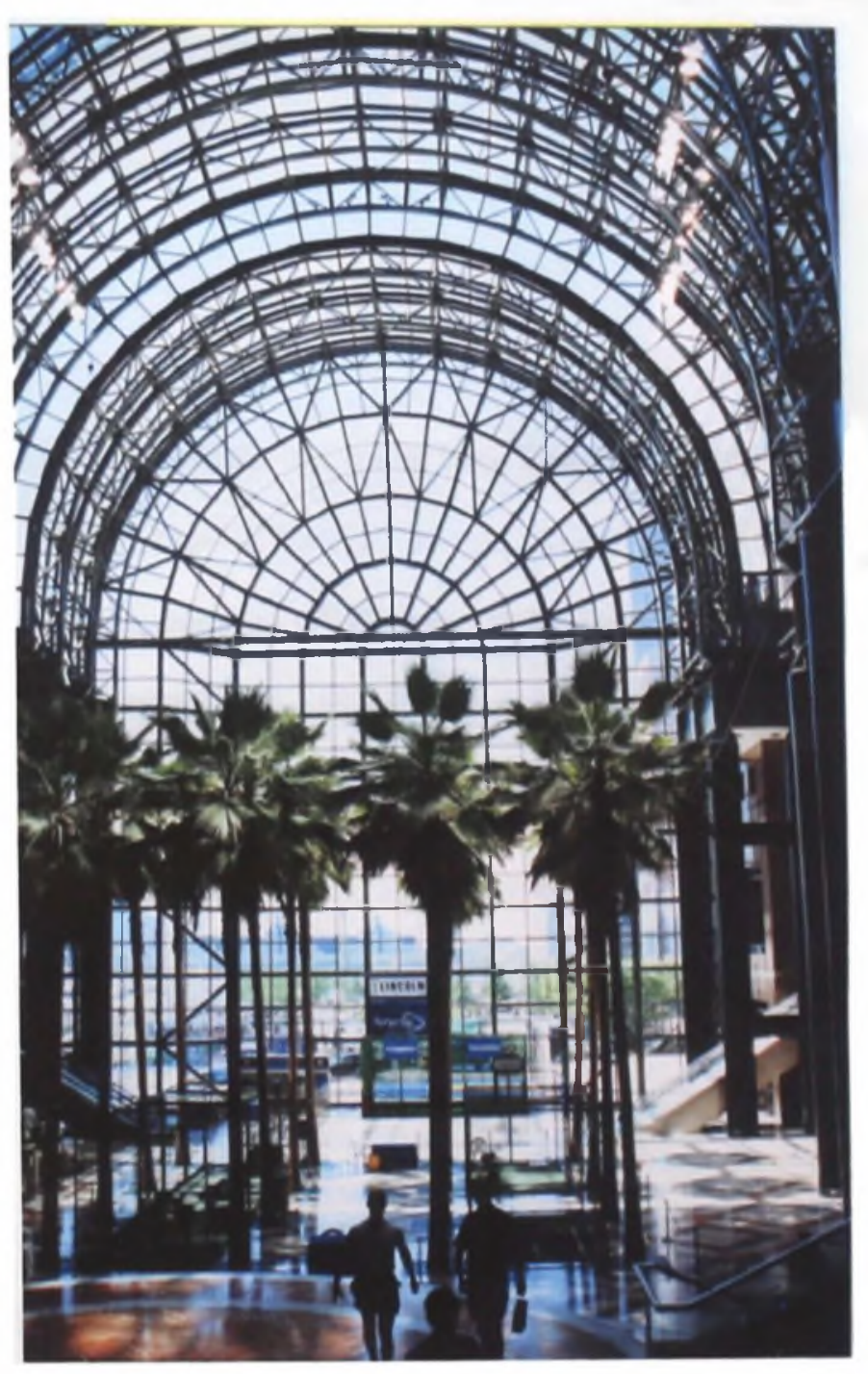



the complications of waterfront renewal However, "the protracted waterfront battles and subsequent delays have fortuitously spared New York (ity from several ill-considered projects ", 5 )

Yet, how does this waterfront revitalization compare to London. home of another one of the world's largest ports and recent waterfront works? Or to Chicago, a city with whom Manhattan has shared many

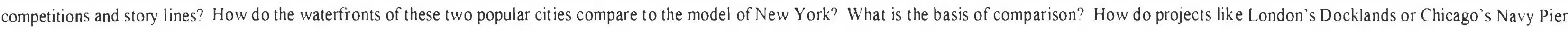

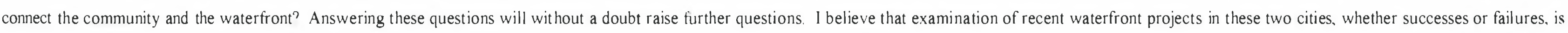

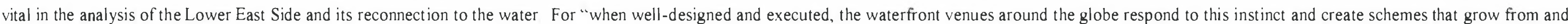
reflect the spirit and aspirations of the city they are meant to enhance" 51

\section{London Docklands}

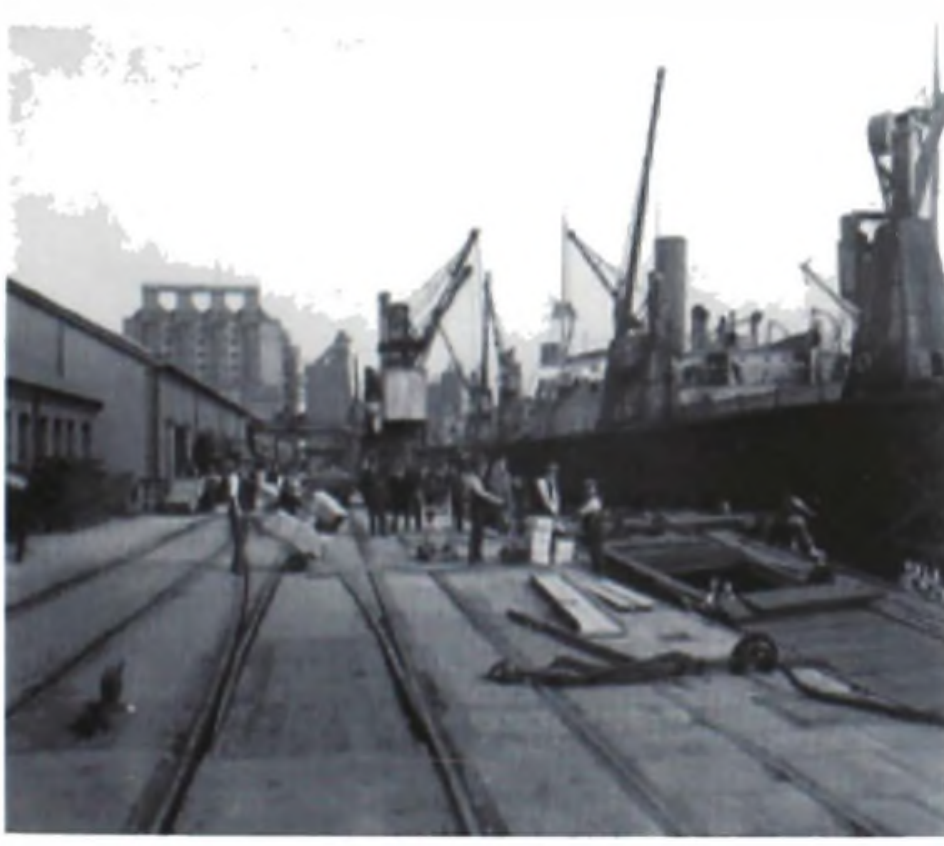

Figure 30: London docks circa 1919
Not surprising, but photographs like figure 30 of London's docks and piers look very similar to those of New York for the same time periods. New York's history is directly related to the history of Britain, as stated earlier. Likewise, the maritime connections between these two vast urban centers can be traced via merchant trade and passenger shipping, as well as war, since the $17^{\text {th }}$ Century. Still, why compare metropolitan, modern cities like New York and London? Quite simply, these two cities are the leaders in the Western world financial markets and are likewise considered the two preeminent global cities. ${ }^{52}$ Both cities advanced as great ports, which led them each to become a major world financial market. As such, nowhere in the western world (through to the 1980's) had development been as aggressive and as visible than in the metropolitan areas of London and New York. "In these two cities not only was a proliferation of new large office buildings replacing smaller structures within the old cores, but enormous, highly visible mixed-use projects were springing up on vacant or derelict land.",5:

In terms of waterfront regeneration, no other city but London can match New York in terms of projects, but also in terms of the roller coaster financial markets of the 1980's and 1990's. Thus, the growth of these cities has been parallel in many aspects 


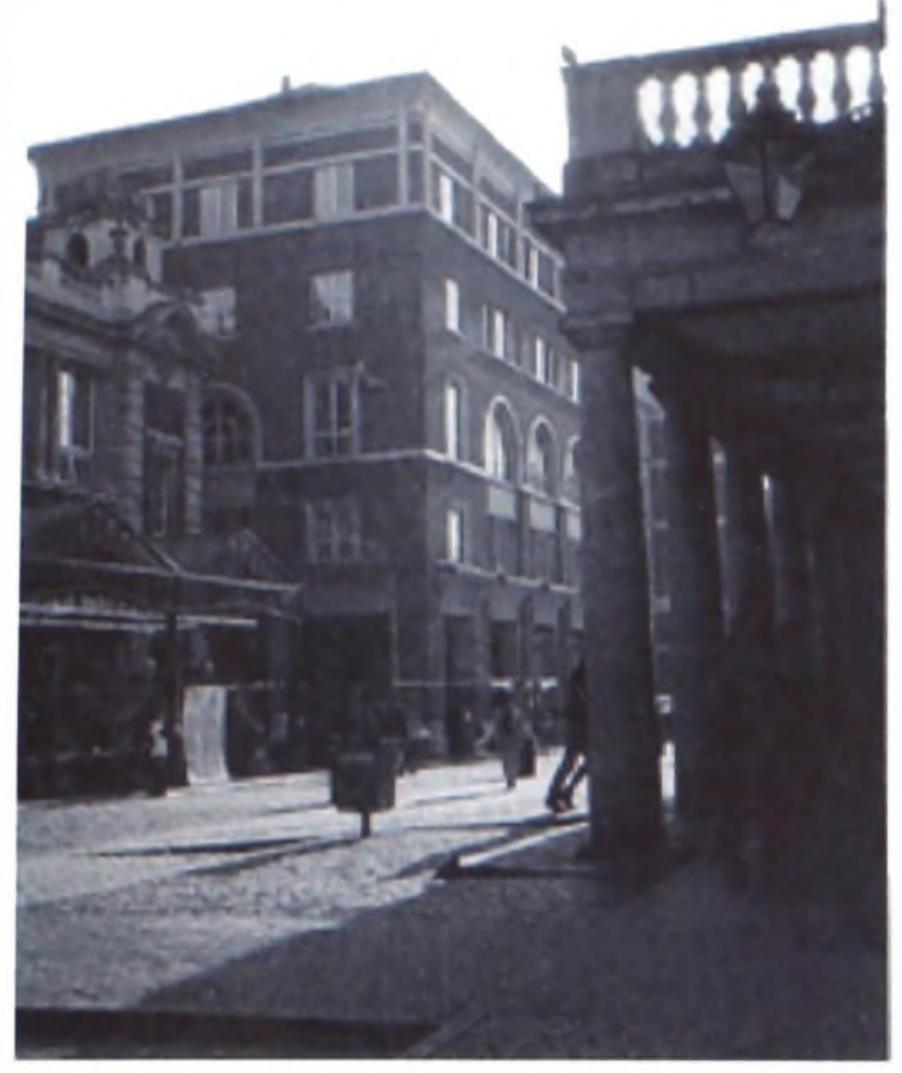

Figure 31: Corent Garden, Wesimmsicr

As a point of comparison, Westminster (often compared to Manhattan's Upper East Side) with its exclusive residents and private firms, saw redevelopment of an old market This market, partially depicted to the left, and its subsequent renovation, transformed "the entire surrounding area [into] trendy retail and entertainment uses, featuring fashionable shops alongside cafes, restaurants, and bookstores" ${ }^{\text {is }}$ The reborn Covent Garden was synonymous to South Street Seaport-from 'historic preservation' to the tourist attraction atmosphere. The residents of Westminster felt alienated and deeply criticized the project. There is a feeling of commercial invasion and no sense of place-almost as if the project was disconnected from Westminster

Another model of comparison (and contention) is London's Docklands. An ongoing project that can trace its beginnings back to the waterfront decline and abandonment of the late 1960's. Likened to Battery Park City but on a much larger scale, the Docklands project covers eight and half square miles (about 5,500 acres) along the Thames River. The Docklands includes the Isle of Dogs and the Canary Wharf (refer to figure 32).

Located in the most deprived area of London, the Docklands were developed under various urban schemes. The Port of London Authority was highly criticized for its inability to regenerate the London docks. A change in the political environment created the London Dockland Development Corporation (LDDC) in 1981. Like the Battery Park City Authority, the LDDC promoted economic development in the area. Its primary focus was to stimulate growth in London. "Instead of viewing the territory under its planning control as embedded within the Docklands boroughs, the LDDC pictured the riverbank as a new vibrant core for the whole metropolis." 55 The entrepreneurial approach, however, showed the lack of control the LDDC would have and foreshadow the financial disasters. Their plan was to make things happen. Unlike the Battery Park City Authority, the LDDC never developed a master plan.

Figure 32: One of many views of the Canary Wharf in London with Cesar Pelli's lower as a focal point

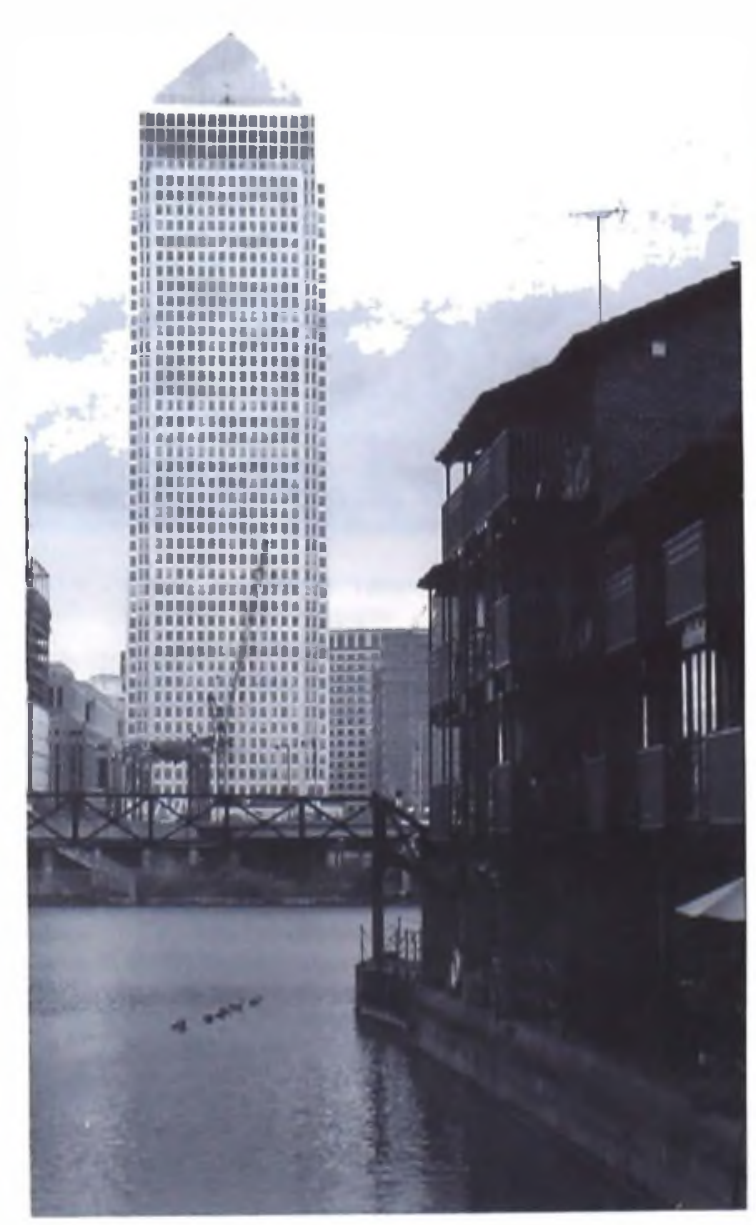




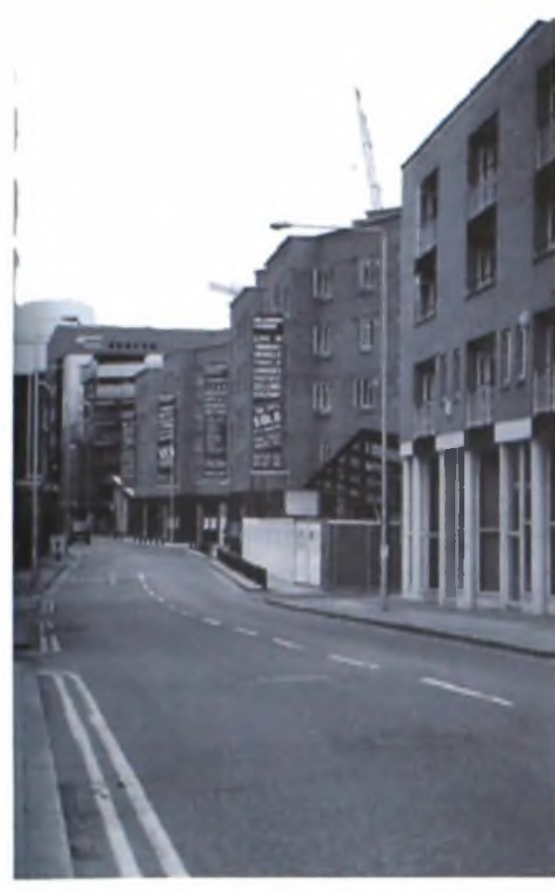

Residential development was the first phase (and priority) of the Docklands project. Consisting of resurrected warehouses and new construction, the structures were ambitious and successful at first. However (refer to figure 33), "except for the nautical themes of their names, the residential complexes made no architectural reference to the communities which they colonized—nor for that matter central London ... indistinguishable in appearance from typical suburban blocks of the low-rise flats anywhere in the southeast". 56 The 1987 market crash affected London just as it did New York, and ultimately halted residential development for years in the Docklands. However, there currently seems to be a surge in the Docklands' market for housing. It is important to note however that no hard numbers are available at this time to support such claims.

Figure 33

\section{The Isle of Dogs}

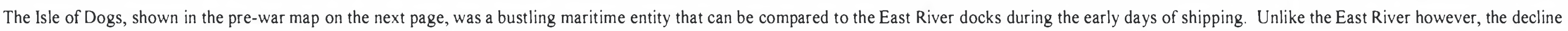

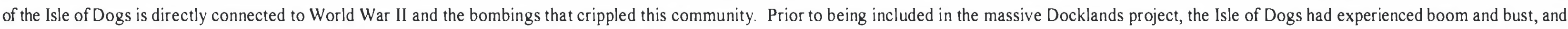

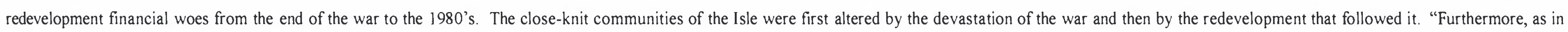

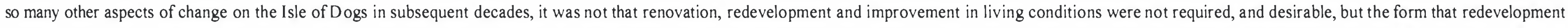
took that was problematic." 57

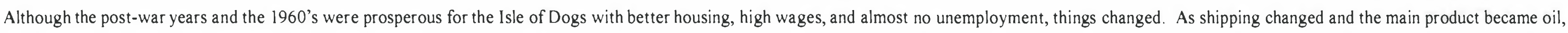

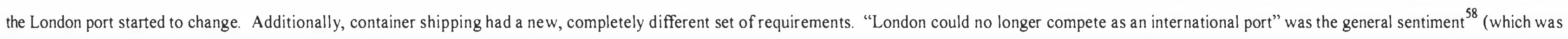

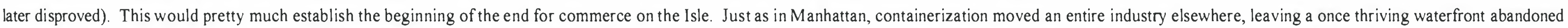
and in need of renewal. 


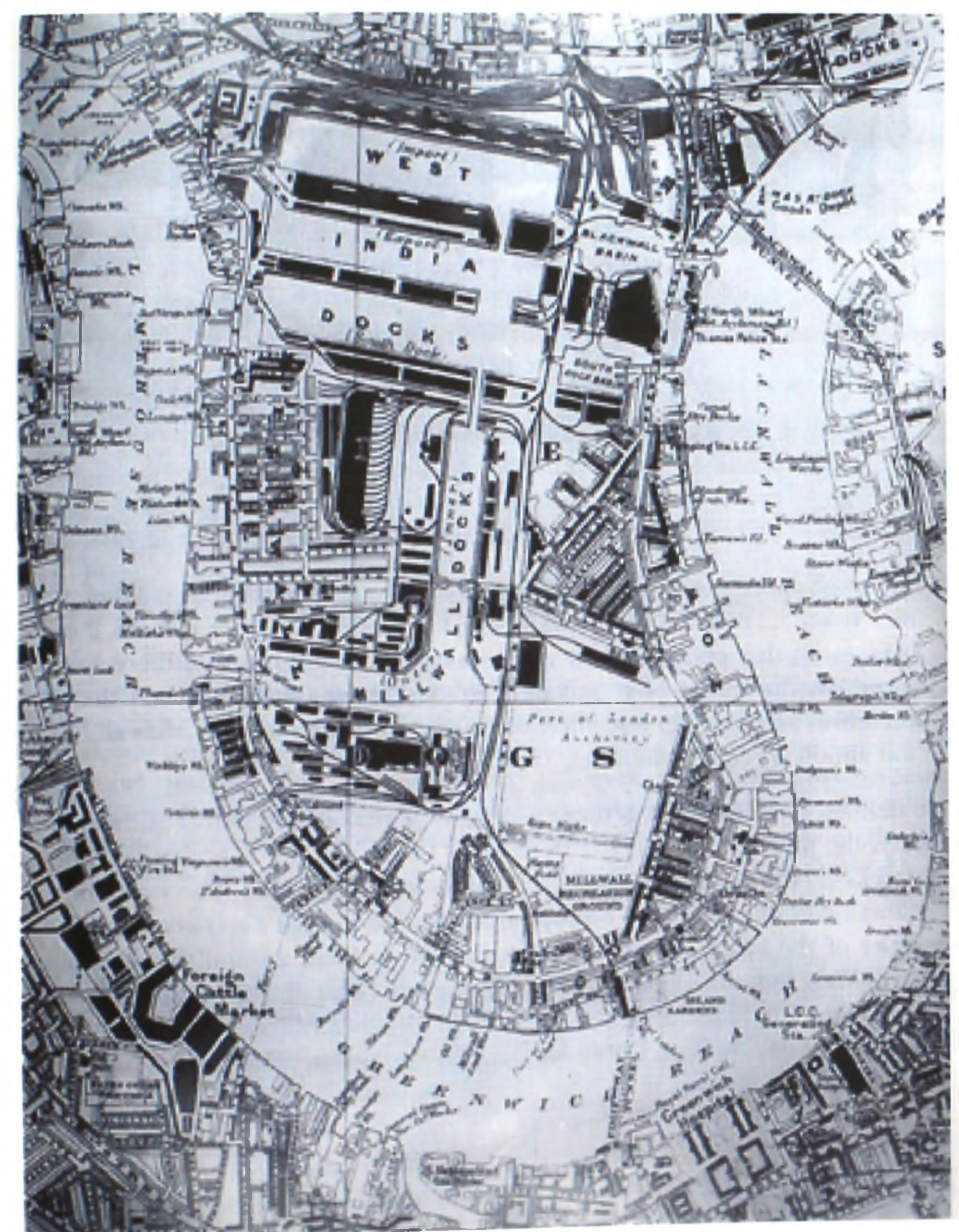

With the LDDC involvement, the Isle of Dogs would be incorporated into the Docklands. The establishment of an intensive commercial development known as the Enterprise Zone (EZ) can be found on 482 acres of the Isle's center. Introduced in 1982, the Enterprise Zone was aimed at the commercial sector in an attempt to bring businesses to the area. Tax breaks, miscellaneous other incentives, and little planning intervention and regulation were the spark, attracting corporations and small businesses alike.

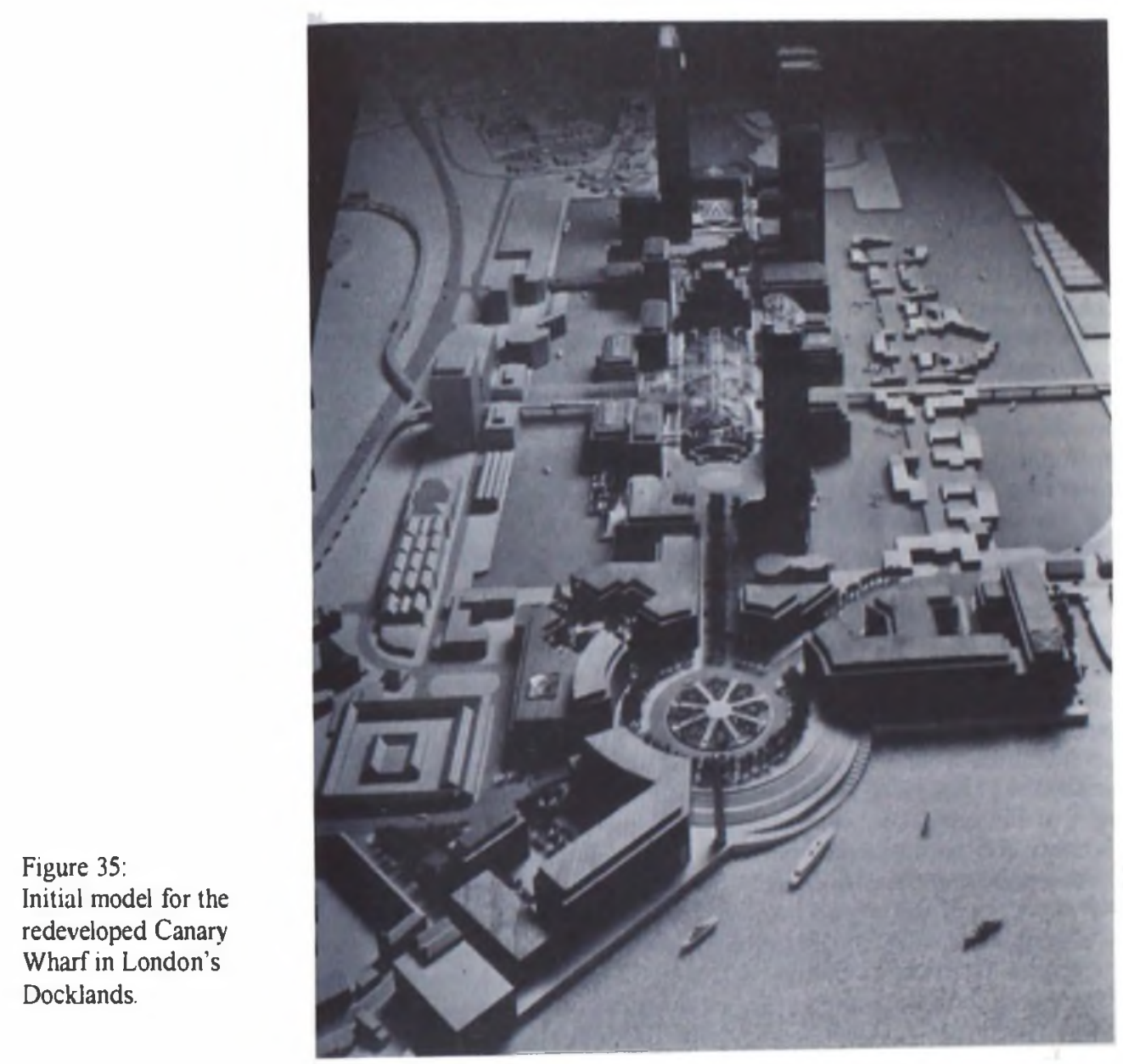




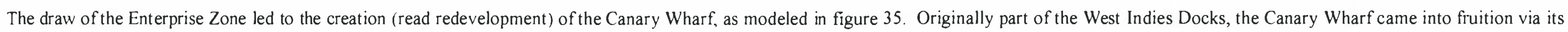
connection to the Canary Islands. Warehouses were stocked full of goods, fruits, and sugar. The Canary Wharf was typically the busiest of the piers and docks on the Isle for 1900 to 1965

These themes of leverage, lack of local democracy and flexible planning had their ultimate expression in the Canary Wharf development. Canary Wharf was announced in the summer of 1985 . The scheme originally put forward was for a $10 \mathrm{~m} \mathrm{sq} \mathrm{ft}$ development on $7 \mathrm{l}$ acres in the Isles of Dogs, 55 acres of which lay in the EZ. Heralded as the largest single property development in Europe at the time it comprised $8.8 \mathrm{~m} \mathrm{sq} \mathrm{ft}$ of offices, two hotels, $100,000 \mathrm{sq} f t$ of service facilities, $0.5 \mathrm{~m} \mathrm{sq} \mathrm{ft}$ of shops and restaurants and over 8,000 parking spaces. Controversially, there were to be three sixty-storey, $850 \mathrm{ft}$ high office towers which were in the line of the view from Greenwich Park, widely regarded as one of the most important and beautiful in London [see figure 35]... it was argued that Britain needed Canary Wharf if it was to stay ahead in the world race to be a financial centre... The developers threatened to go to Frankfurt or Paris, London's European rivals, if they did not get a site in Docklands. ${ }^{59}$

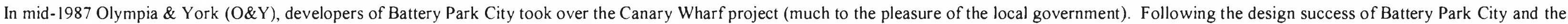

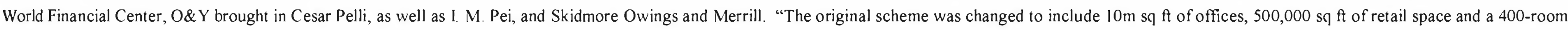
hotel", and two of the three "towers were reduced to $690 \mathrm{ft}$ and the centre tower moved". 60

Figure 36: The Canary Wharf on the Isle of Dogs. Docklands. London

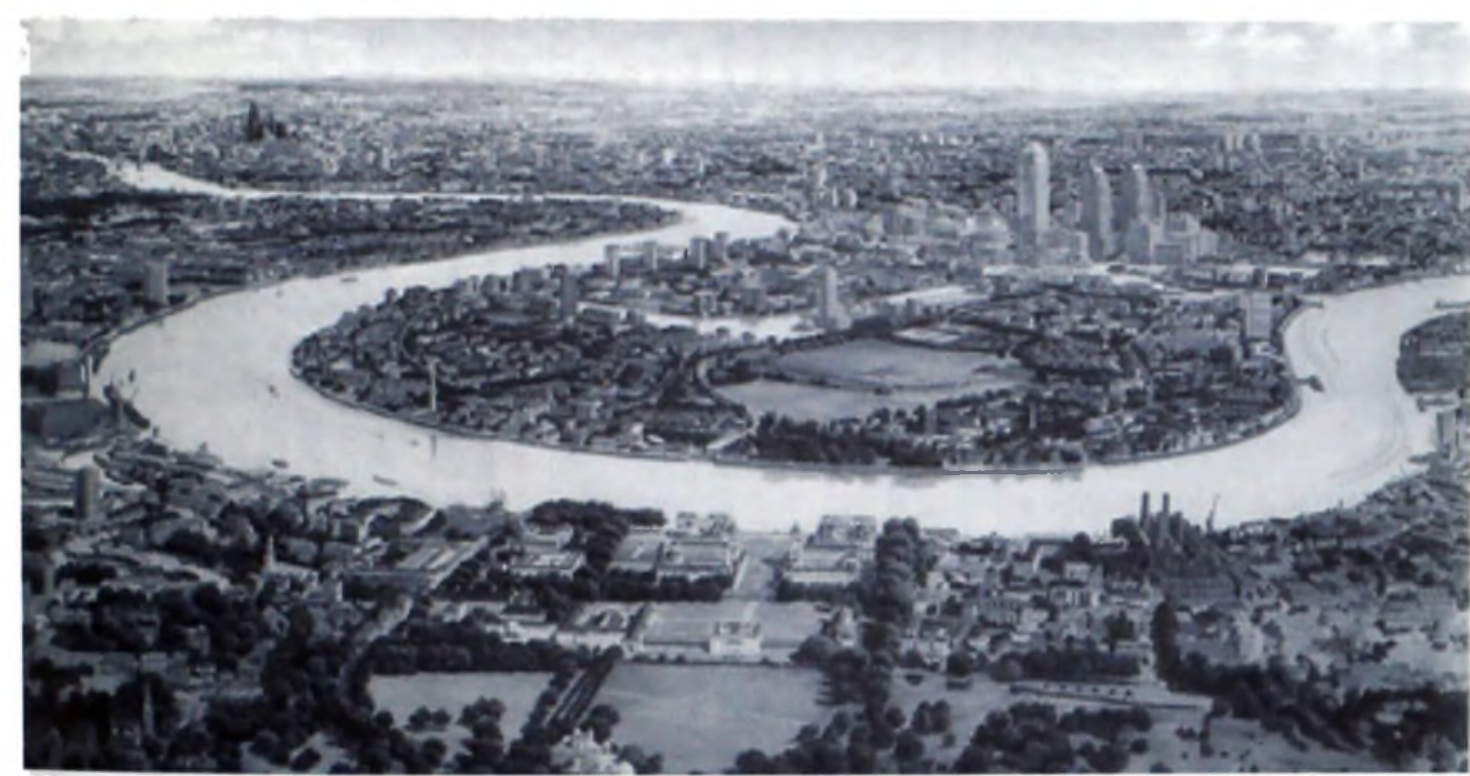

O\&Y sunk outrageous amounts of money into the Canary Wharf. Following the success of Battery Park City, they created open spaces and public amenities that amounted to more than one-third of the land dedicated as open space O\&Y also took over control of the failing ferry service between central London (Charing Cross Piers) and the Docklands. Considered by many to be an attempt to recreate 'Wall Street on the water', Canary Wharf did become a great, technologically advanced commercial district

Canary Wharf (depicted in figure 36) was unfortunately struck with the early 1990's market slump. At a time when hardships were increasing and corporations downsizing, O\&Y was still in the habit of buying out leases in Central London to get tenants to move to Canary Wharf. In the end, this and other unsound leasing deals would devastate Olympia \& York. The World Financial Center in New York was O\&Y's only lucrative asset and was also the only part of the firm's portfolio not under bankruptcy protection in the Americas

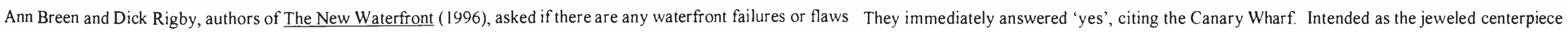

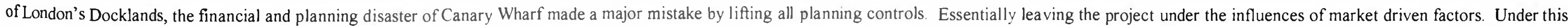




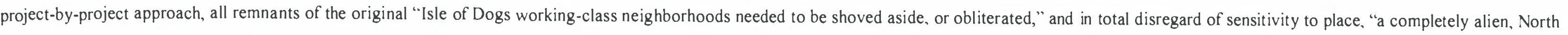
American-style project was built". ${ }^{61}$ In the end, the E5-billion price tag of the Canary Wharf bankrupted O\&Y, who was then the world's largest development corporation.

Figure 37

The Canary Wharf. Pelli's Tower and the Millenium Dome

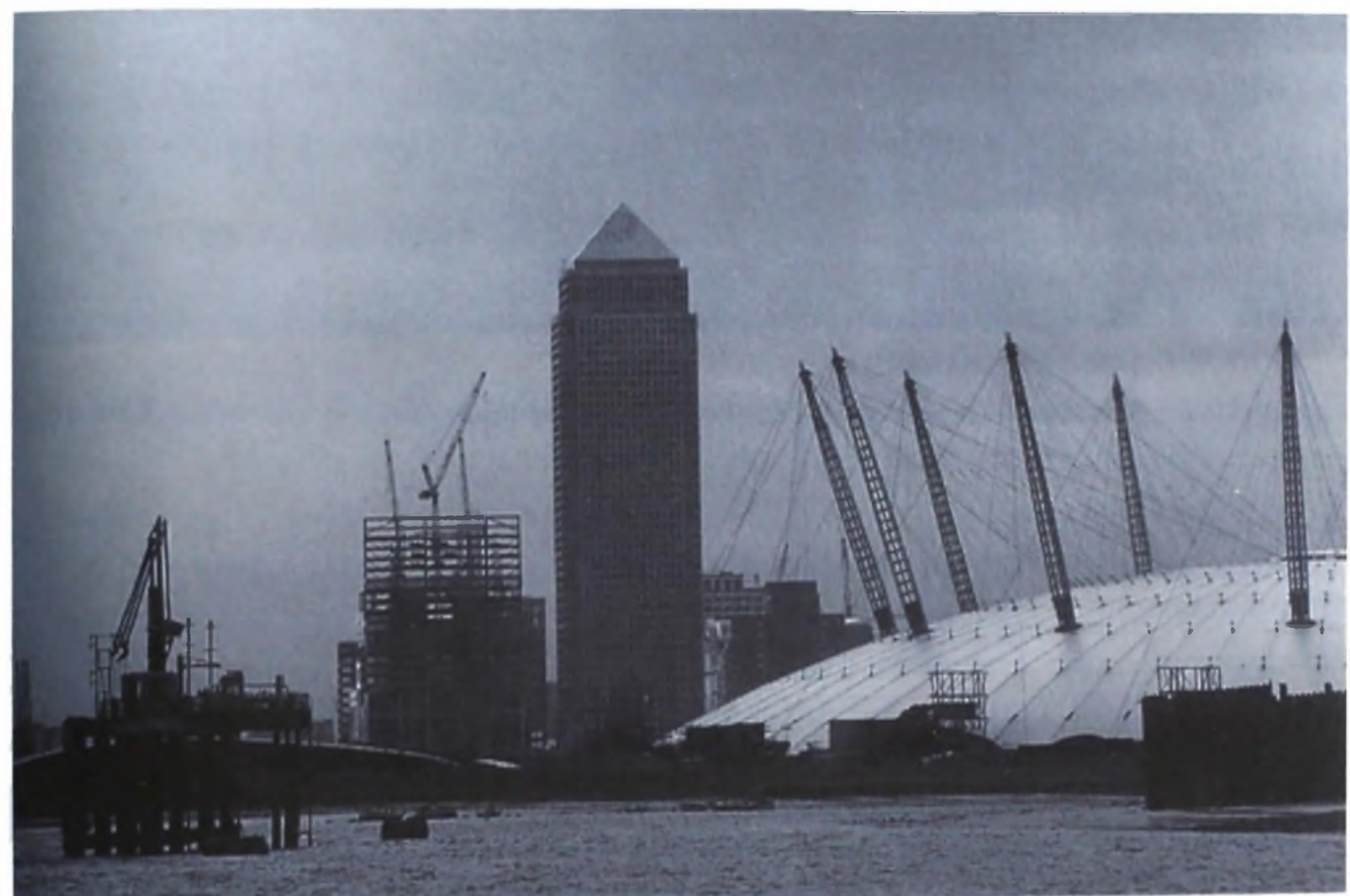

The Docklands however may be on a rehabilitative upswing. As seen in figure 37, the late 1990's construction of the Millenium Dome and other works in the Docklands brought millions to the waterfront for the Millenium celebration. The Dome, it was hoped, would bring additional development. As of this writing, London is still undecided as to sell or demolish the abandoned icon, with recent reports claiming that it could become a biomedical research center. ${ }^{62}$ Also visible in figure 37 , is One Canada Square, the tallest (seventy-stories) office building in Europe. Mimicking the structure at the World Financial Center, One Canada Square has been criticized as the sore thumb of Europe-standing alone without the benefit of a Manhattan-like skyline to blend into. Although criticized as it is, the office tower is extremely successful of late and practically all leasable space is full. Additionally, a refinanced LDDC has started work on the Royal Docks. Now using strict planning and design guidelines as well as a master plan, the LDDC seems to have learned from its earlier mistakes. Likewise, smaller projects on the Isle of Dogs and the Enterprise Zone have been aimed at small users, design firms, and the professional services industry and have been well received by the local critics

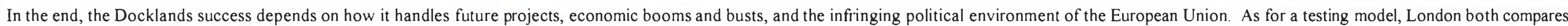

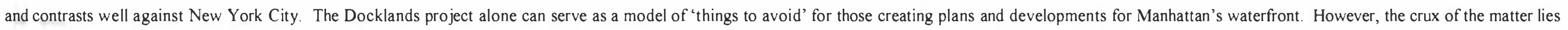

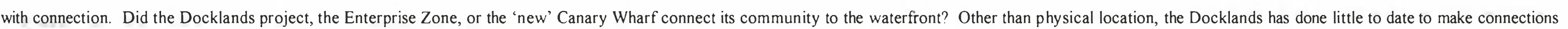

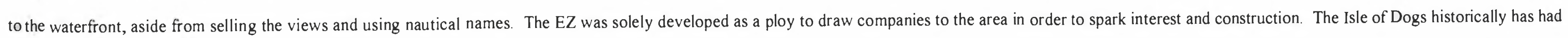

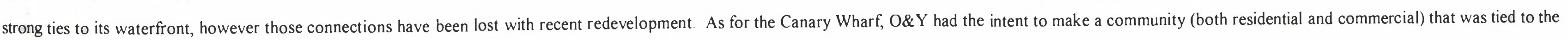

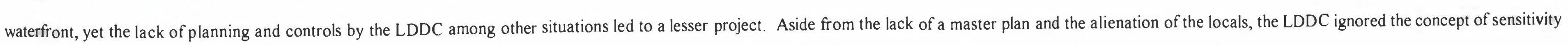

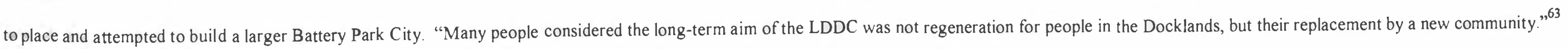




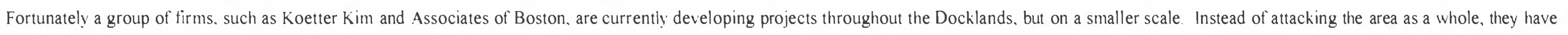

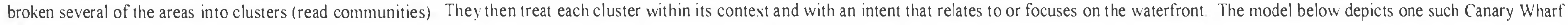

Figure 38 Koetter Kim and Associates model for Western Segment. Canlan Wharf.

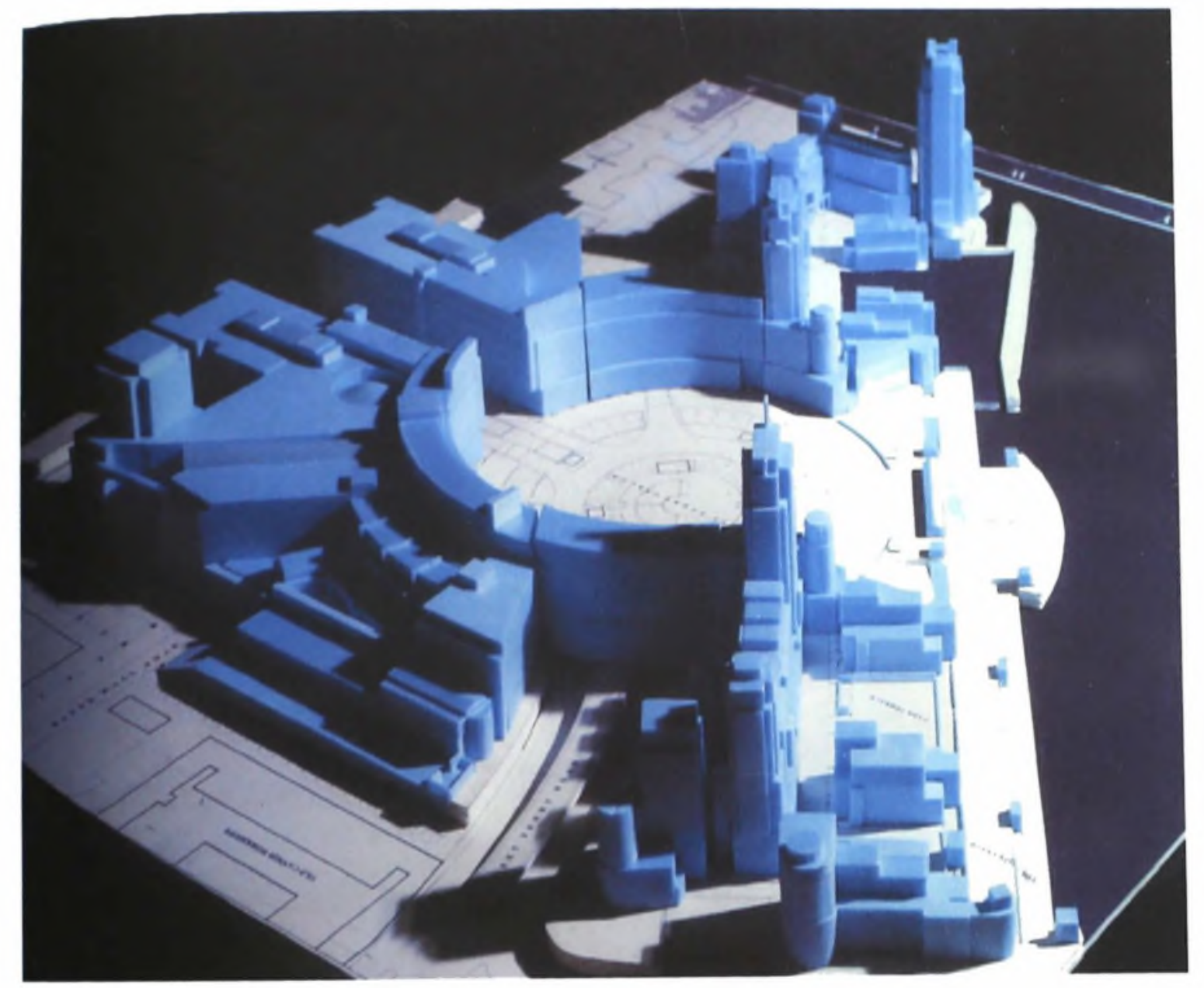

cluster, Western Segment Koetter Kim treats their design as "a response to the intrusion of large-scale built objects and insular activities into an ongoing urban setting" (- To soften the edges along the water and add comparable scale to the existing tall buildings, Koetter Kim utilized a step-down approach as it neared the waterfront Aside from "the dramatic views" and "waterside gardens" that open to the river, they were able to dissolve the harshness of the waterfront while engaging neighboring conditions 65

This site is just one several that Koetter Kim is currently developing throughout the Docklands. River Pier, Blackwall, and Port Greenwich are but a few, and they all have a common theme of connection. Valuing the importance of the Thames riverfront, each cluster is designed as a portal, "an important point of transition between land and water". 66

How does this work as a model for New York? Or as a model for the reconnection of the Lower East Side to the East River? Until recently, it was a model of what not to do. An example of what may seem good on the cover is actually not so good once one delves inside. "Expensive housing, the closure of local firms, rising land values which pushed rented housing and other social facilities out, all compounded feelings that, in reality, the local community was not wanted. ${ }^{, 67}$ In this author's opinion, New York would do well to serve as a testing model for the future of Docklands. First and foremost there must be a master plan, and this plan needs to include the input of

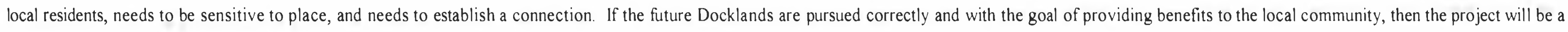
success, which Koetter Kim and Associates are currently attempting to do. 


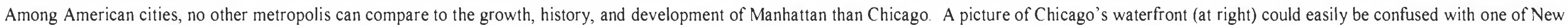
York. Even the landfilling (figure 40) that took place resembled that of what happened around the southern tip of Manhattan.

Figure 39: Chicago docks circa late 1800 `s

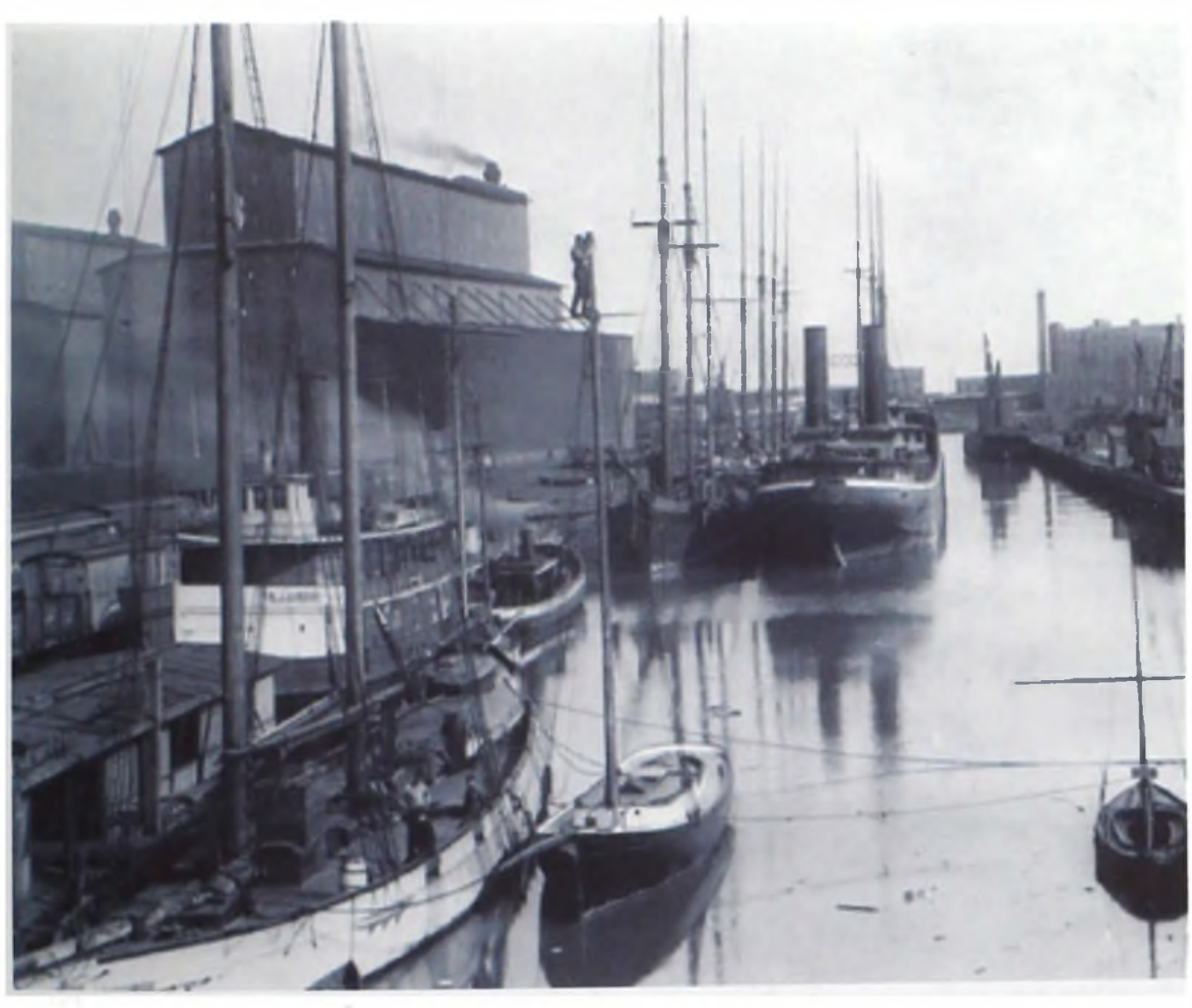

Figure 40: Landfill action on Lake Michigan, circa 1928

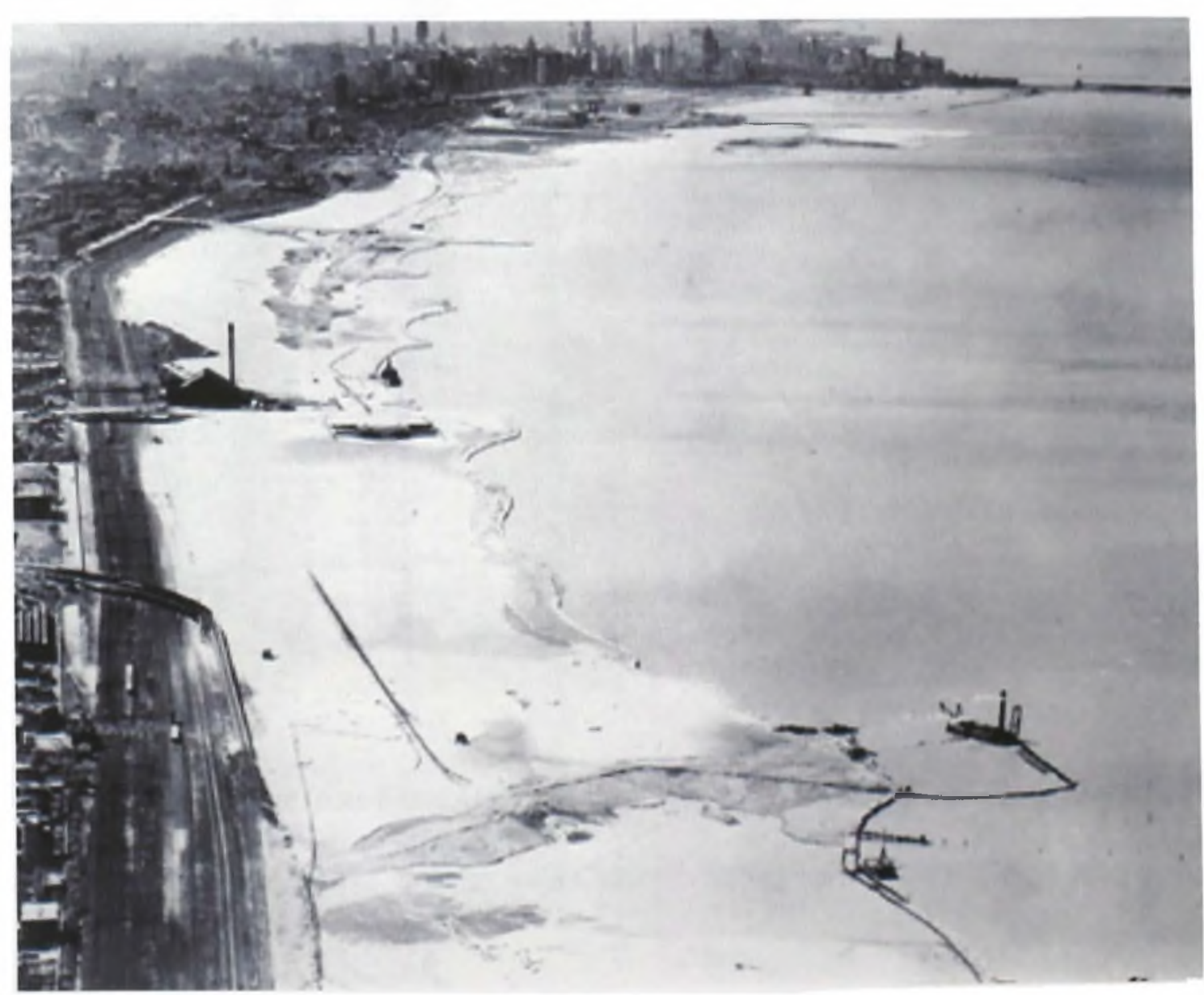




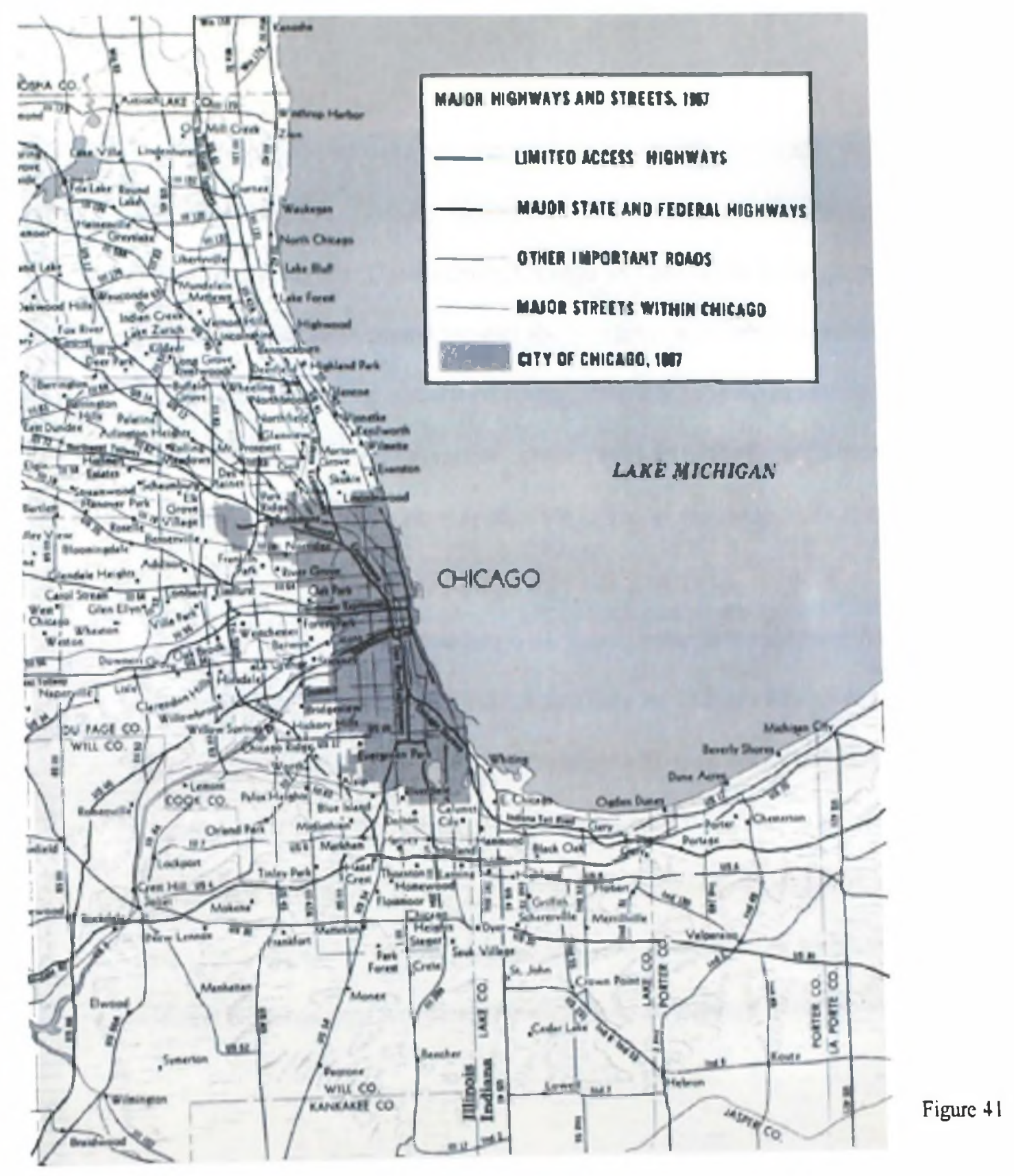

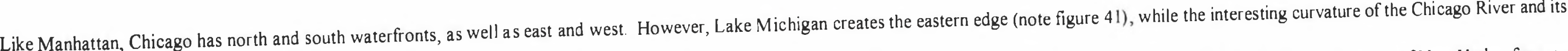
42) create the north, south and west sides. 68 Originally a marsh land, Chicago had to fill most areas as it grew. In many ways Chicago's history mirrors that of New York-from early settlements to major disasters to the skyscraper craze. 


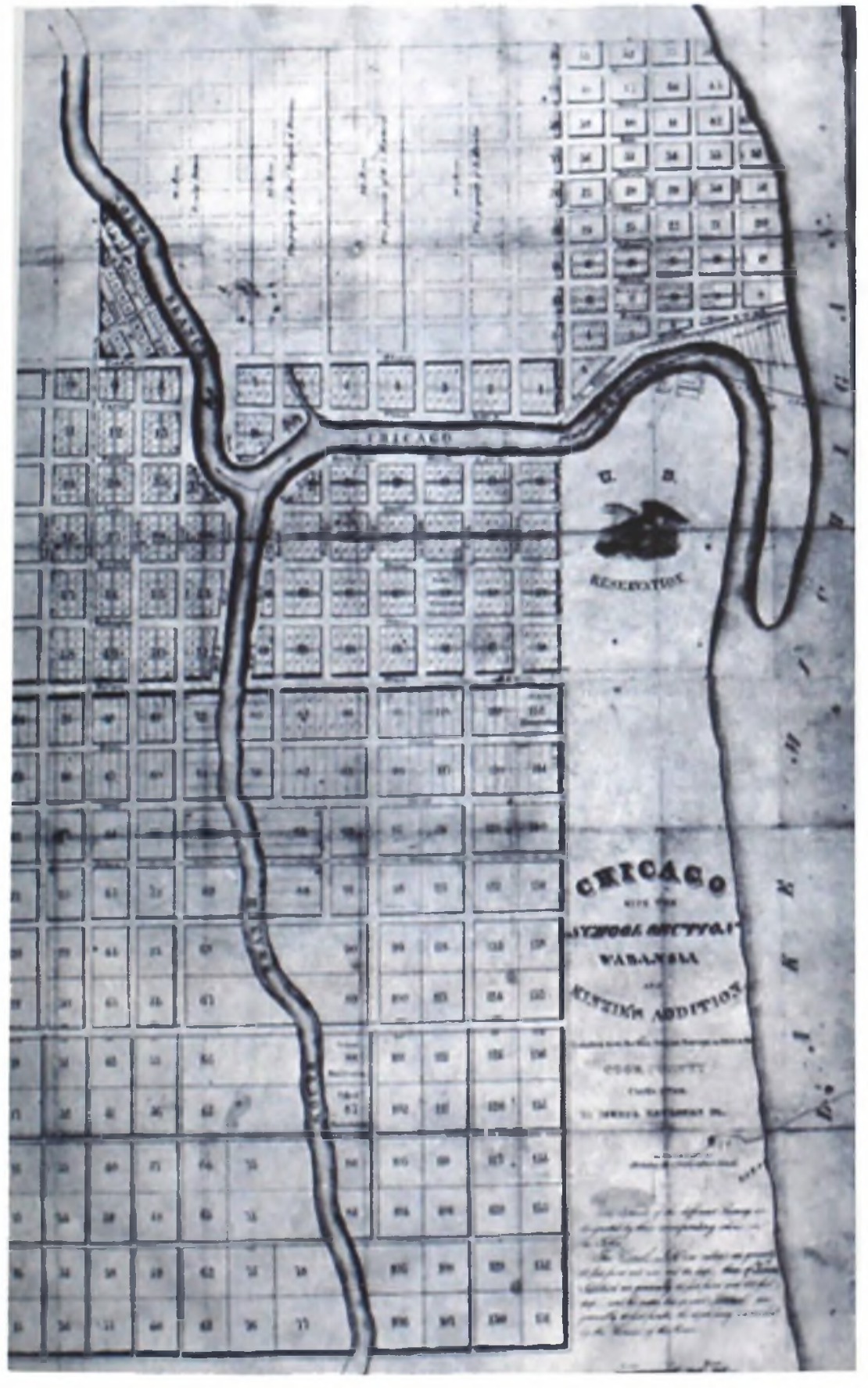

Chicago's waterfront however dealt almost entirely with trade since it lacked a direct ocean access. Nevertheless, the piers and docks were quite busy, full of sailing ships and steamers (and later modern vessels) meeting the ever-growing rail industry that connected the city to the rest of the country. Conveniently, Chicago was one of the few metropolitan cities that had the space and the infrastructure to quickly meet the needs that containerization brought about. This in turn helped to establish Chicago as the predominant city in the nation for rail transport. Without venturing off on a historical tangent, it would be more beneficial to examine the city's current waterfront. The following facts can be taken as given: major industries have been a large part of the Chicago River (and its clean-up), Chicago is a dense city with congestion equal to that of Manhattan, and the city has often attempted to create recreational and public facilities along Lake Michigan (refer to figure 43).

As a whole, Chicago has had better public waterfront amenities than New York over time. This is further evidenced by the recreational emphasis placed on Lake Michigan's shore while the Chicago River was always treated as an area for business and industry. Moreover, additions to the Adler Planetarium (1991) and the Shedd Oceanarium (1992) reinforce the public's presence along Lake Michigan. Throughout the late $20^{\text {th }}$ Century, Chicago has focused on its recreational needs as well as its residential needs. Many programs in the Comprehensive Plan for Chicago, published over the years, outline numerous areas of growth and/or renewal for residential purposes (most of which were inland sites with a few along the river). Additionally, those plans along with a variety of Lakefront Plan[s] of Chicago. focused on the upkeep and addition of recreational facilities, most of which can be found along the waterfronts.

Figure 42

Map of Chicago River.

Note the interesting curce near the mouth of the

river, creating a finger-like peninsula 


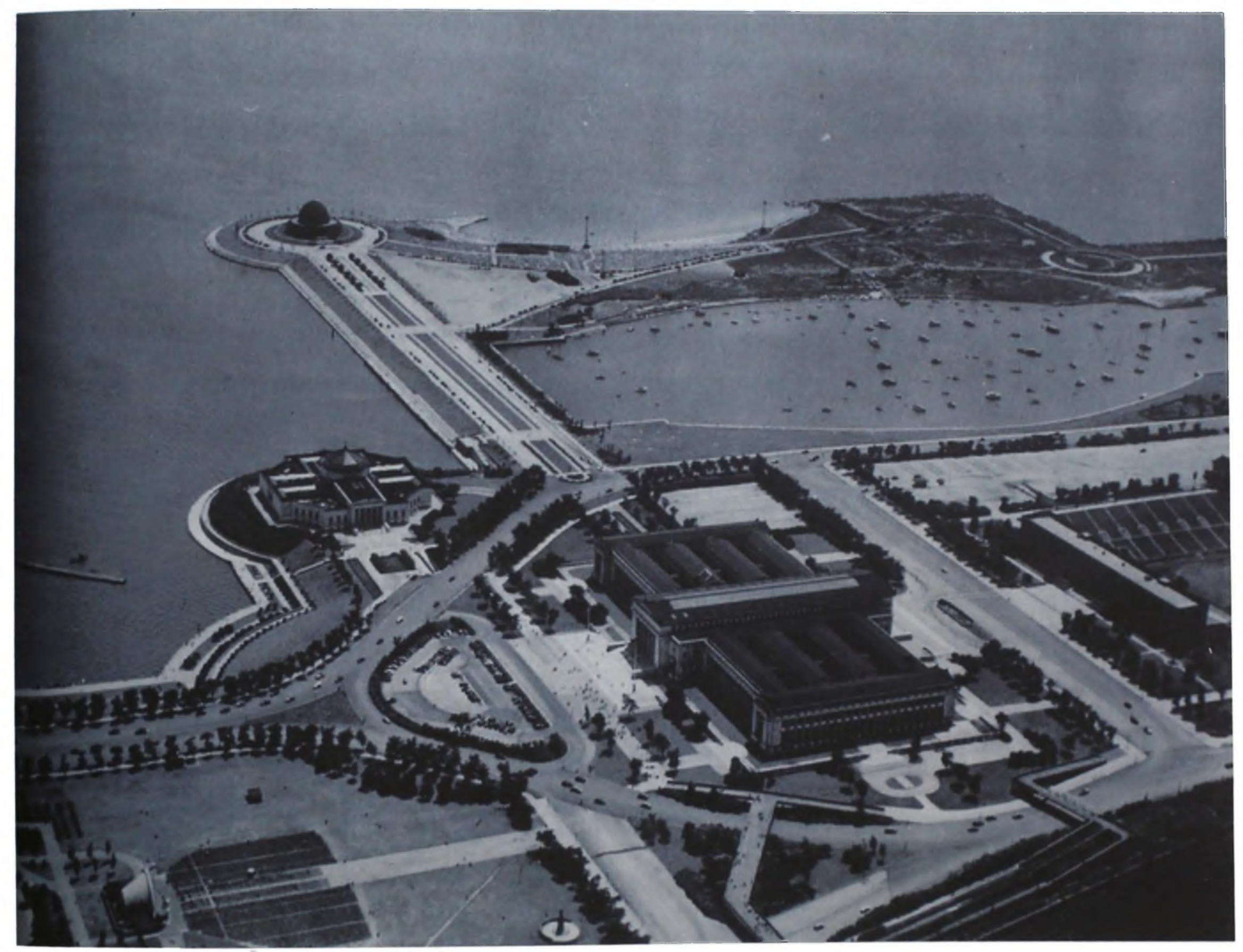

Figure 43: Grant Park, Chicago

Home to the Marshall Field Museum, John G. Shedd Aquarium, and the Adler Planetarium and Astronomical Museum. 


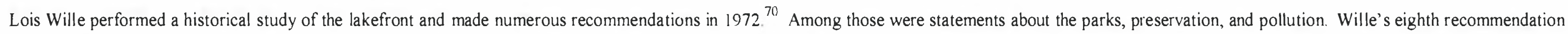

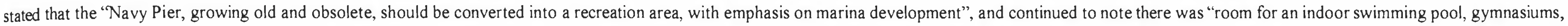

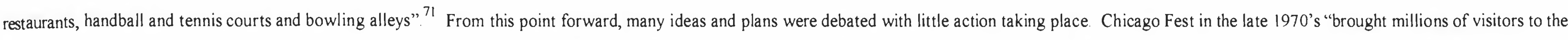
facility, stimulating a move for the planning and development of a more permanent use for the site". 72

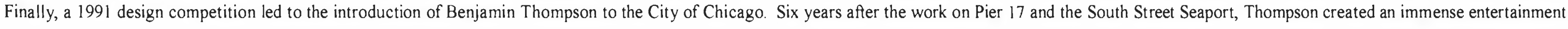

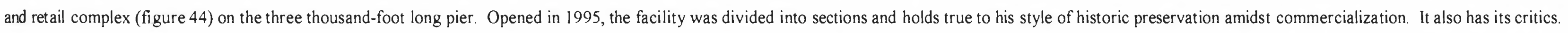

Figure 44: Clicago's Navy Pier by Benjamin Thompson

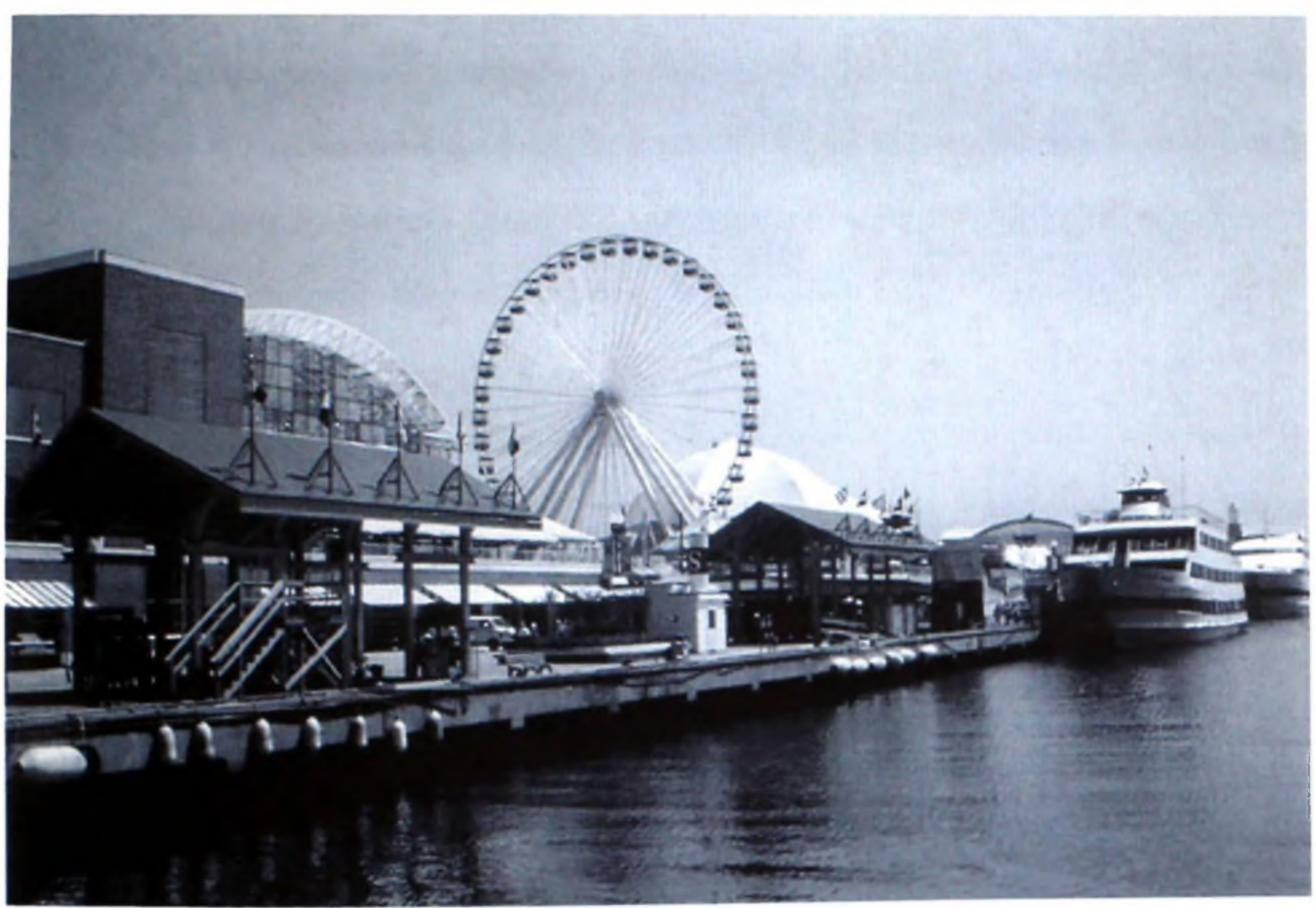

"The structure is pleasantly dominated by a Ferris wheel... Apparently controversial, the wheel at night is indisputably a major landmark and has historic significance-George Ferris first displayed the amusement ride that now carries his name in Chicago in $1883,{ }^{, 73}$

Among the structures that compose Thompson's new Navy Pier include a Family Pavilion at the pier's original head house. This area includes a Children's Museum and an IMAX theater along with the prototypical shops and eateries. A six-storey glass atrium is next. This building, the Crystal Gardens, is home to an immense botanical exhibition. The south edge of the pier provides a promenade, stages for various entertainment, tour boat dockage, and retail carts. The Ferris wheel and a late $19^{\text {th }}$ Century carousel mark the beginning of Pier Park, along side of the south dock. A pond/skating rink, retail complex, and the fifteen hundred seat, tensile topped Skyline Stage form the rest of Pier Park (visible in figures 44 and 45). A small exposition hall and beer garden can be found just before the lavishly restored Grand Ballroom at the pier's end. "The ballroom's former grandeur, including its eighty-foot domed ceiling, has been restored, and it will be used for special events and performances, much as it was in its early days. ${ }^{, 74}$ The Navy Pier claims to offer the best view of both the skyline and the lakefront of 
Figure 45: View of Chicago's Nary Pier

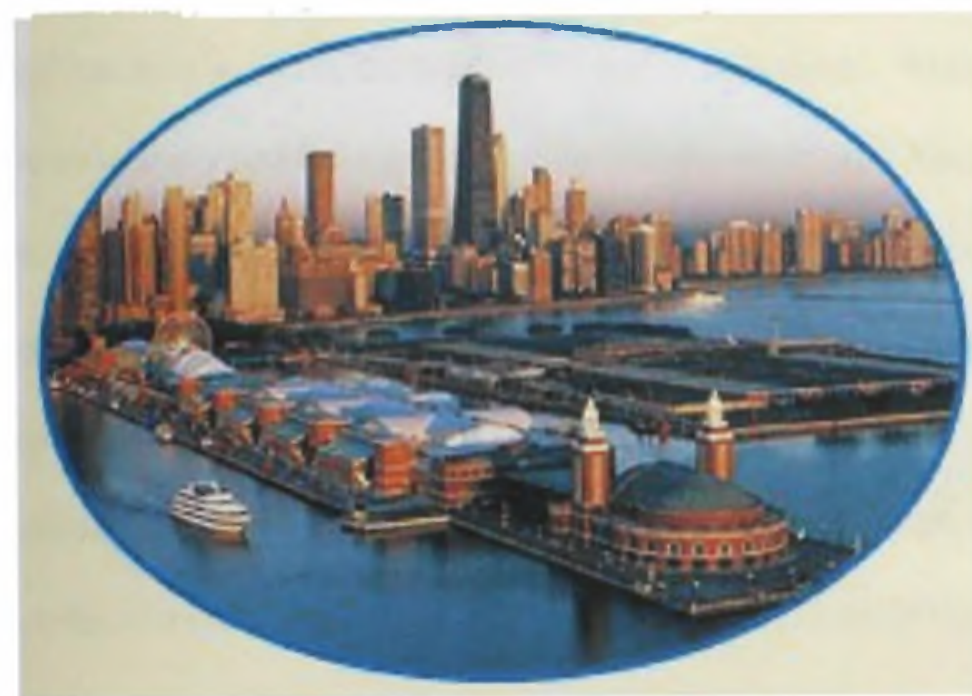

Figure 46 :

Aerial View of Chicago's

Lake Shore Drive and the

green corridor along the lake.

The Navy Pier may have had its initial critics and controversy, but after the public's appreciation and the praise for the rehabilitation of the original Grand Ballroom, Navy Pier was deemed a huge success. Unlike South Street Seaport, Chicagoans were quick to accept the complex and its offerings. However, it is important to note that in New York, Thompson's project was initially presented as an example of historical maritime preservation. In Chicago, the rebirth of the Navy Pier was always to be recreational. Considered a "glorious lakefront facade", 75 the debate however has been (and continues to be) over who uses/benefits more from Chicago's waterfront amenities-the tourist visitors, businesses, or the local population. Who knows what the final outcome of that debate will be for all three enjoy their share. What is interesting to note is how the city connects with its waterfront. For Chicagoans, connection takes on more of a pleasurable, recreational, connotation. While some segments of the city have no direct relation to either body of water, the residents still feel connected due to the number of facilities and amenities available to them along the water. This also serves as reasoning for the local support of the Navy Pier. Granted, there is a historical significance to the pier as well as the attitude to retain some history with the project Yet, it is the recreational component that makes it successful-giving the community what they wanted (and what was advertised).

In conclusion, Chicago serves as a positive model for comparison of redevelopment of waterfronts. It is important to note that Chicago has historically treated large tracts of its Lake Michigan edge as public domain. This is still evident today, as figure 46 depicts the compact solid city on the western side of Lake Shore Drive, and the expanse of green and beaches on the east side. It is possible that Manhattan can examine this development in Chicago and apply accordingly, and in context, to what is Manhattan

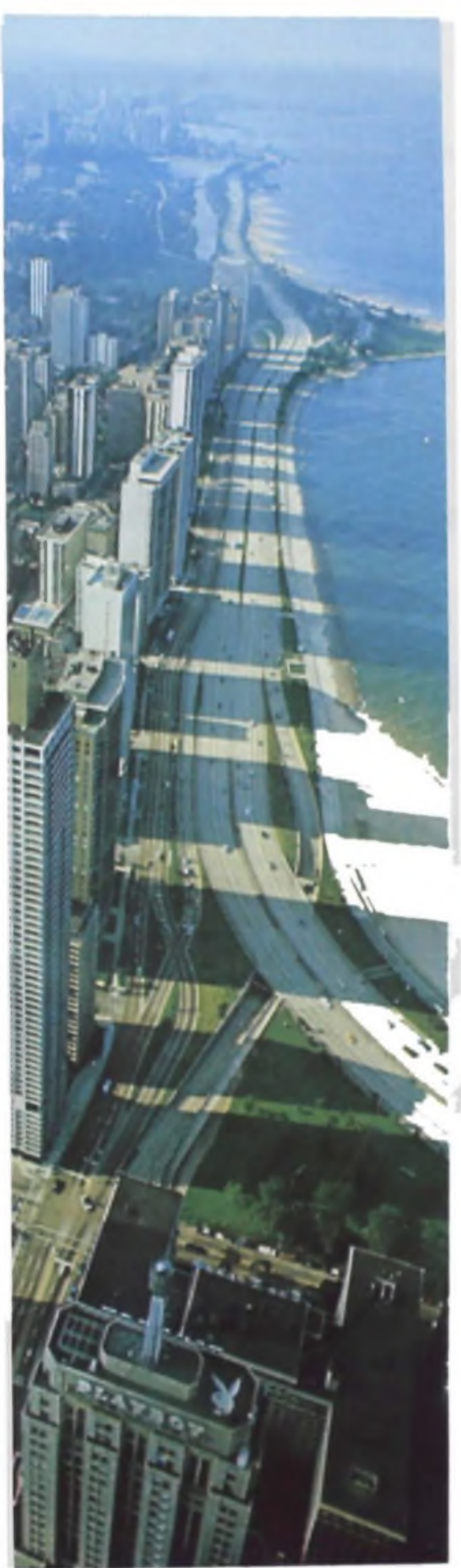




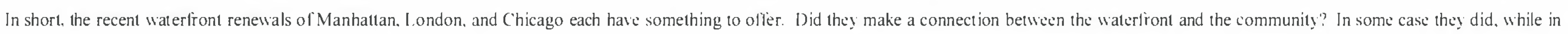

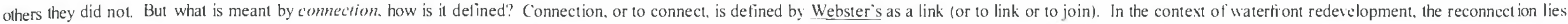

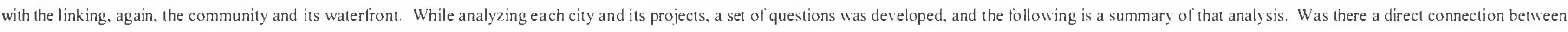

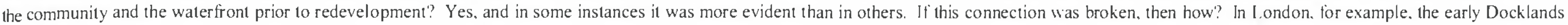

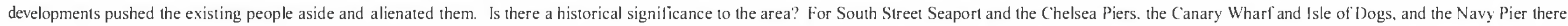

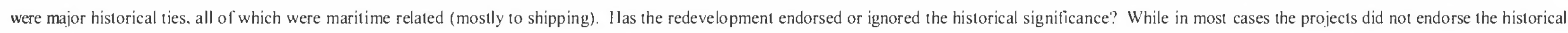

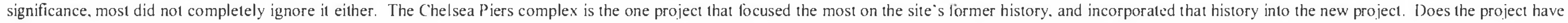

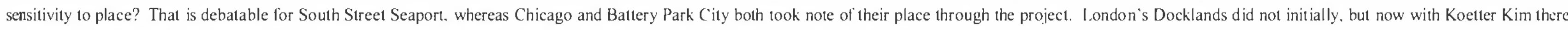
is more intent to work with a sensitivity to place. Each on of these questions will also be applied to the Lower fast Side and the proposals for reconnection to the East River.

The Lower East Side and its llistory

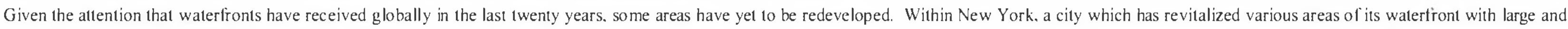

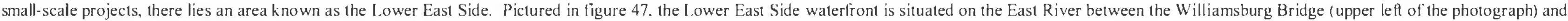
the Brooklyn Bridge (partially visible in the lower right of the photograph). The Manhattan Bridge is in the center of the photograph

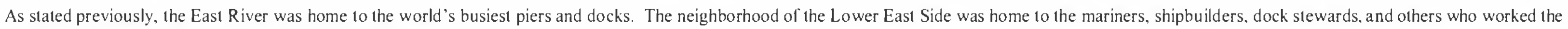

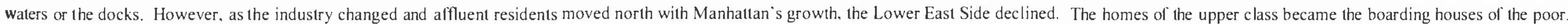

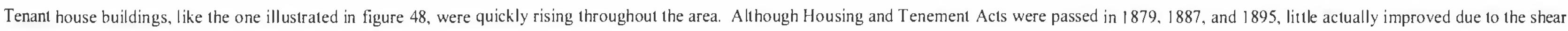
volume of immigrant growth along with the lack of enforcement. 


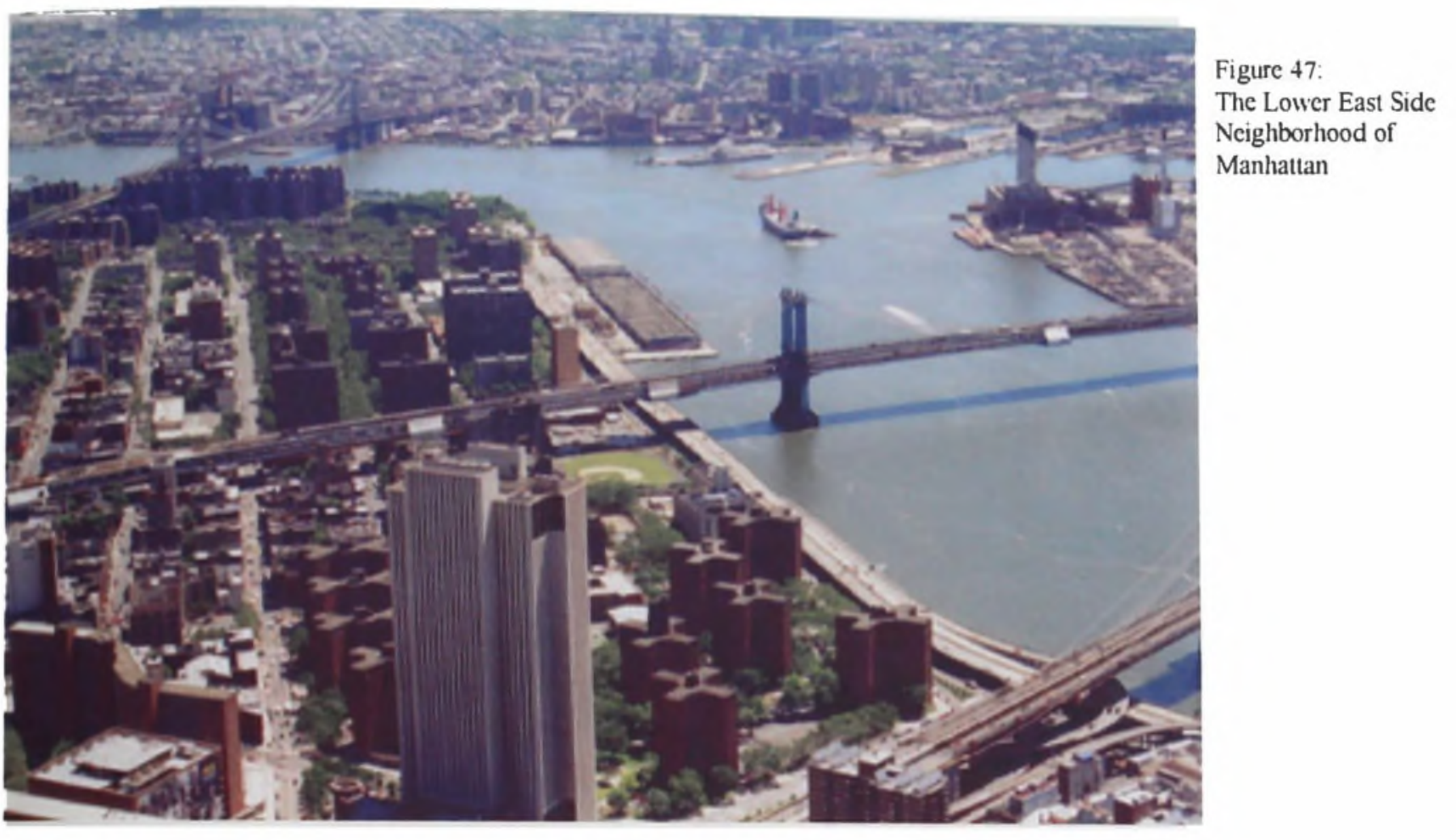

Figure 48: Typical Tenement Apartment Building

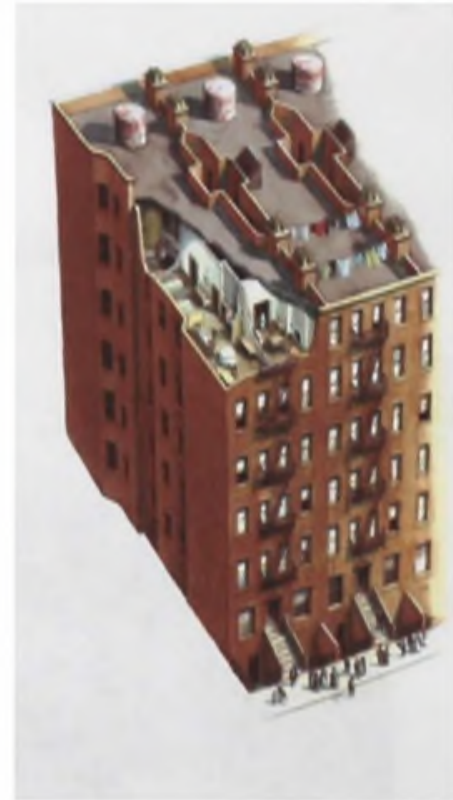

For the vast majority of immigrants streaming into New York at the turn of the century, the path from Ellis Island led straight to the Lower East Side. By 1900 , its 450 blocks had become the most densely crowded place on earth-home to more than half a million people already, with thousands more arriving every month... Now there were more than one thousand people per acre... a concentration of humanity unlike anything ever experienced in world history, before or since. ${ }^{76}$

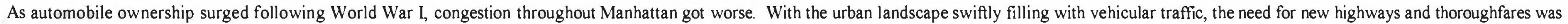

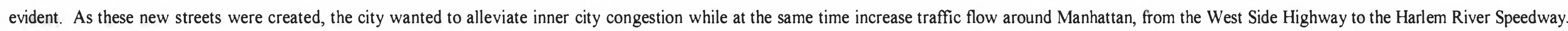

\section{The Franklin D. Roosevelt East River Drive}

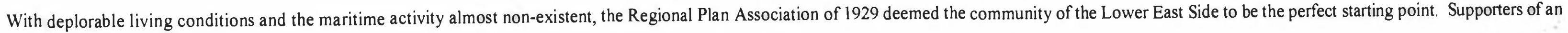

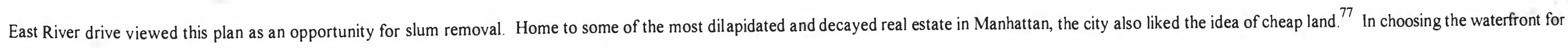

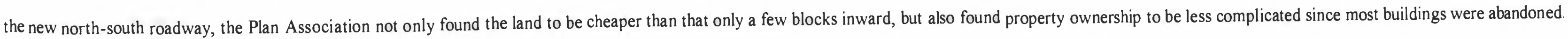

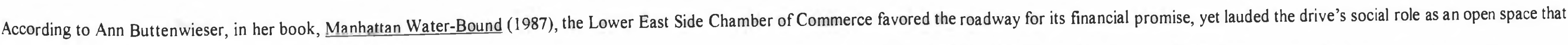

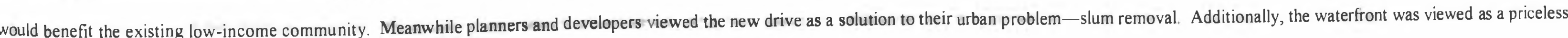




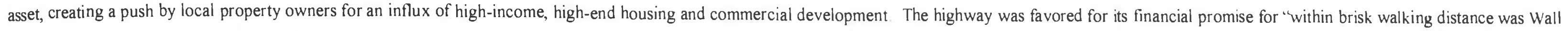
Street and its upper-income jobs, which with the road would bring in a higher class of residents". 78

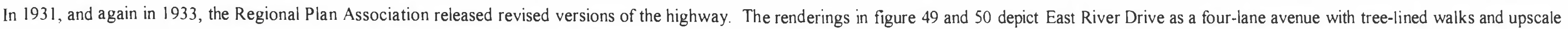
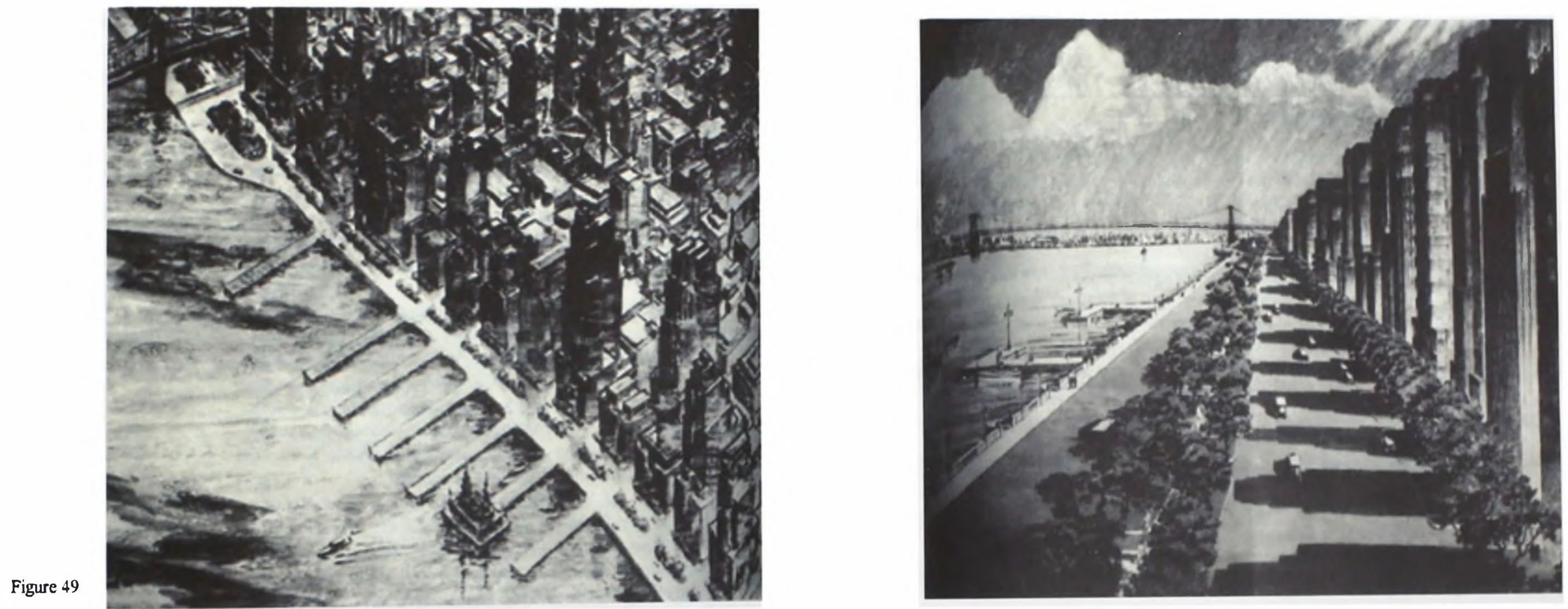

Figure 50

high-rises inland along with a parkland corridor and a green buffer to the east with new waterfiont businesses. Other schemes and plans would surface including an idea for a yacht basin at Corlears Hook near the Williamsburg Bridge.

Social reformers supported the revival and rehabilitation of the Lower East Side Community. They were however opposed to a highway at the water's edge. "The waterfront... was a 'really priceless asset' and it could become 'the most potent factor' in the Lower East Side's revival," cried the opponents, concerned 'that the proposed motor highway would simply cut off those living on the interior of the Lower East Side from the city's shore" ${ }^{79}$ Fortunately for these opponents, little roadway construction actually took place. 


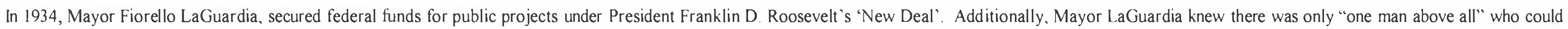

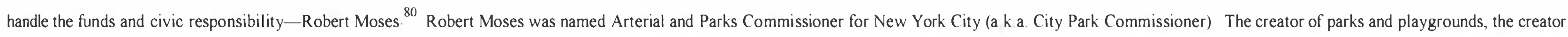
of bridges, and the builder of public amenities, this one man would forever change New York's landscape

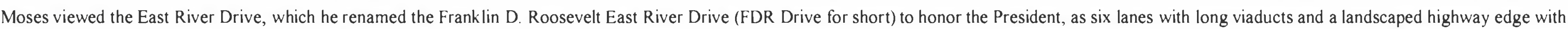

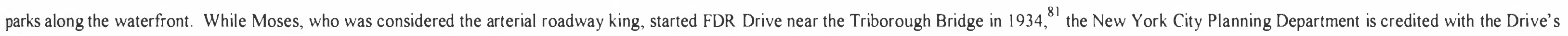
construction and completion.

Figurc 51: Current picturc of FDR Drive, north of Corlcars Hook

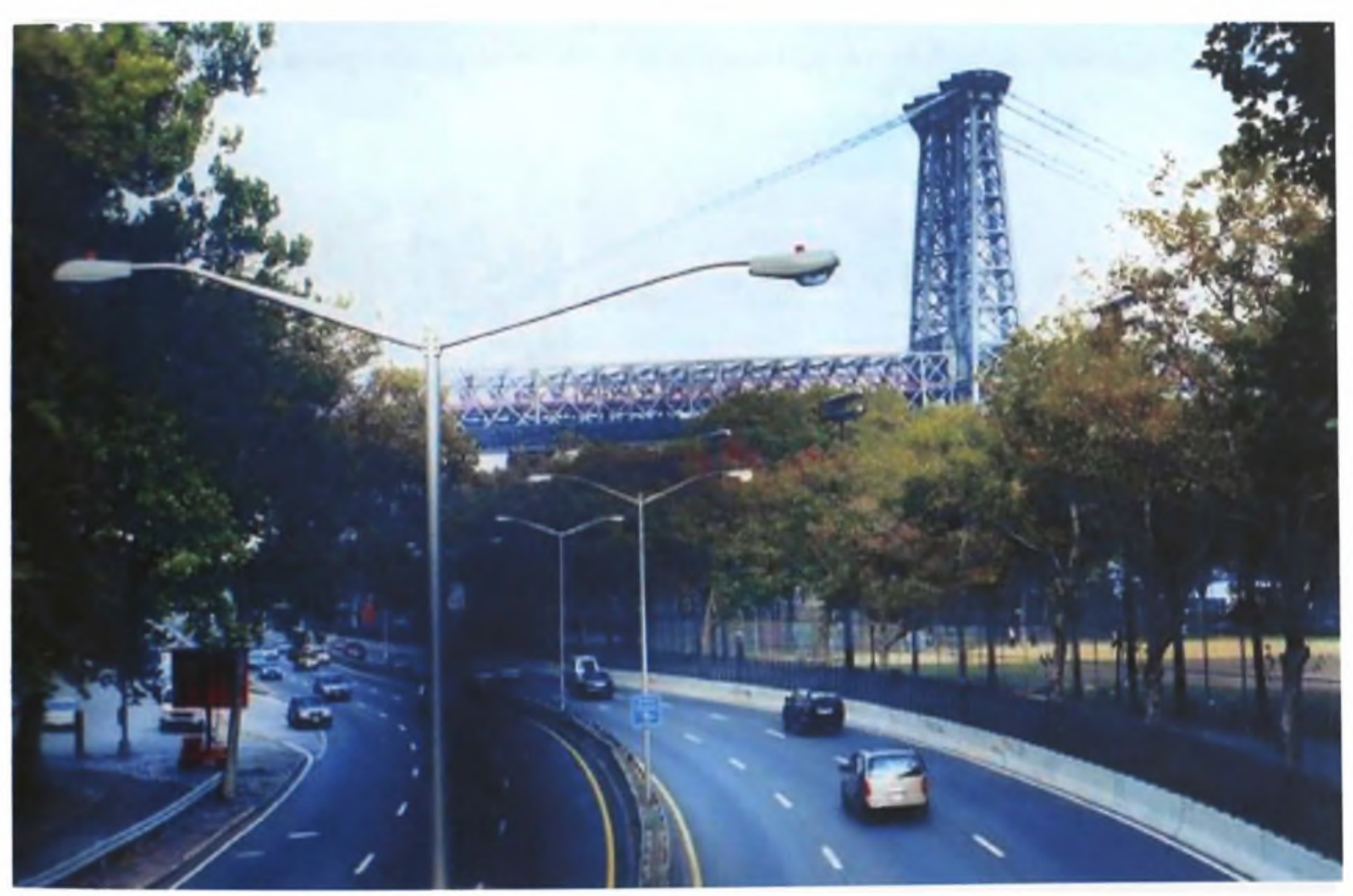

Moses' vision for FDR Drive met with some problems, including insufficient space along the water's edge. He decided to stretch the land over piles in the East River to guarantee the green/park corridor, see figure 51. Although the area of Moses work was not in the Lower East Side neighborhood, it gave hope of what was supposed to develop. As work began in Corlears Hook (near the Williamsburg Bridge) to demolish old tenements and abandoned buildings, the scope of the project changed. Although developers still pushed for upper-class residences, the federal funds secured by the Mayor were for public housing use and redevelopment of lower-income communities. With the adjacent housing slated for a "less affluent group, the roadway took back its mantle of traffic relief," and for the first time, the news reports described the East River Drive "as a continuous lane for fast traffic" 82

As construction for FDR Drive commenced, the Lower East Side's decline continued. Chamber of Commerce leader, Orin Lester, produced the article "What Do We Have to Look Forward to on The Lower East Side?", in which he states that some buildings "should be improved for low-income housing ... [b]ut the

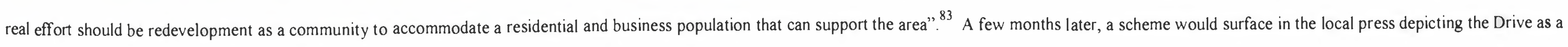
beautiful, parkland lined avenue with art deco style buildings along the western edge. 


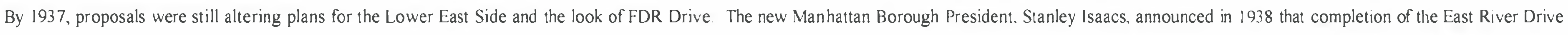

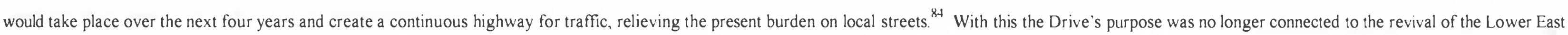
Side neighborhood

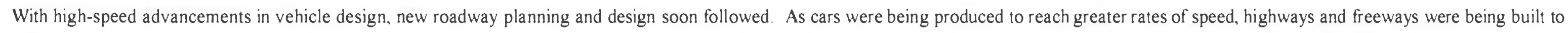

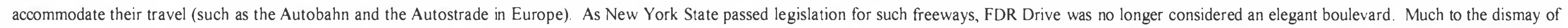

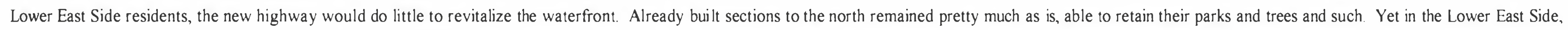

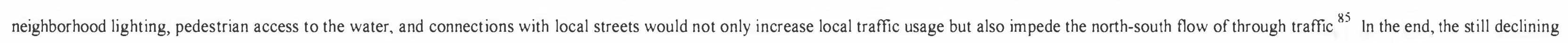

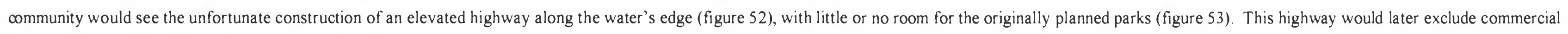
vehicles and become an express commuter way that allowed easy access from the Financial District to other areas of Manhattan and the boroughs without using the surface streets.

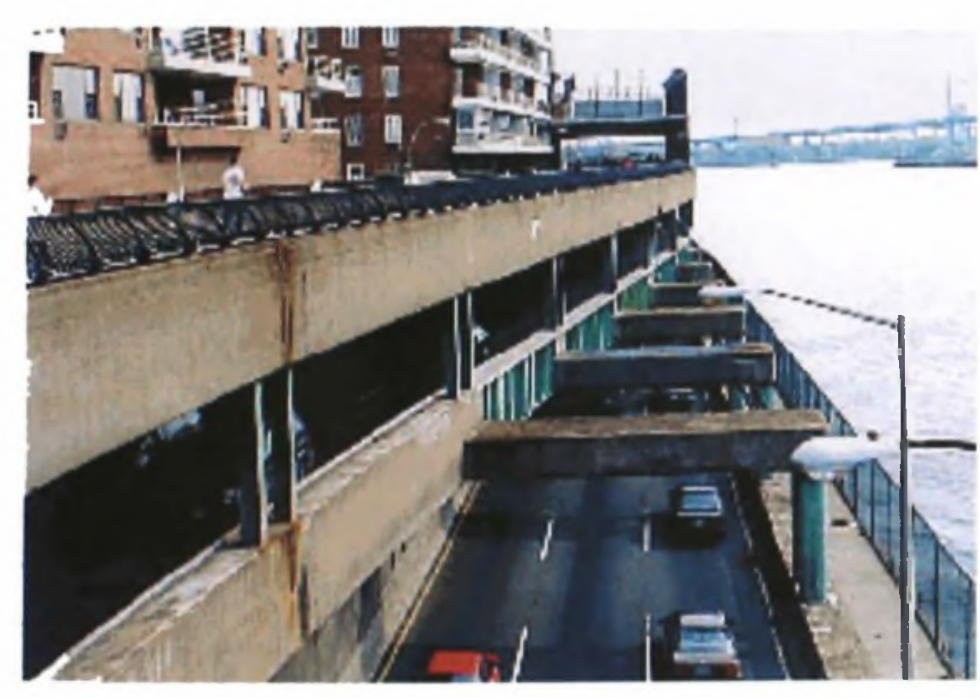

Figurc 53:

FDR Drive in the 1990's. note the proximity of the highway structure to the aparment buildings and the pedestria walk above the southbound lanes.

Figurc 52: FDR Drive circa 1949

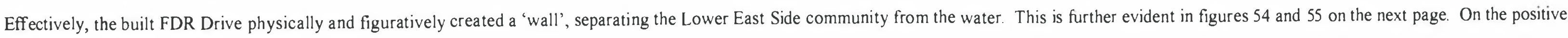

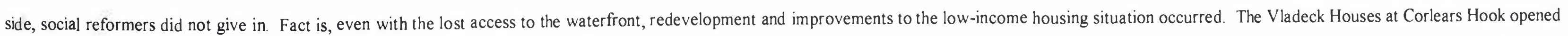

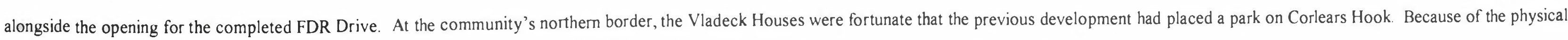

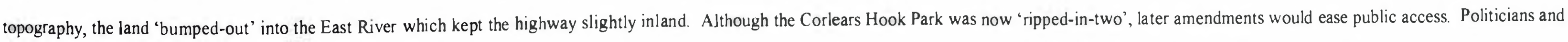
highway supporters were relieved by the redevelopment success of the Vladeck Houses, stating that the highway had done its job and revived 'a' neighborhood, 


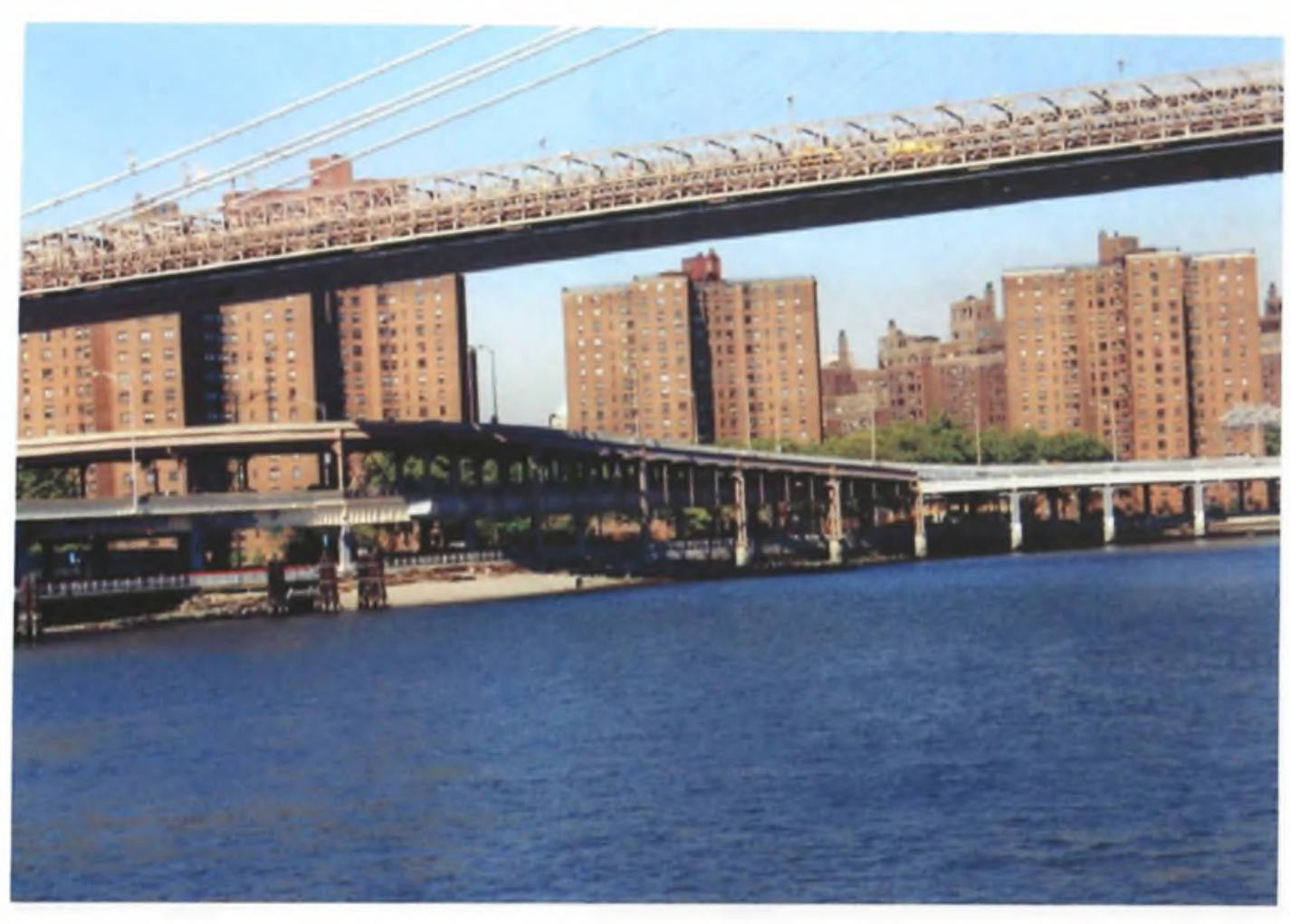

Figurc 54: FDR Drive

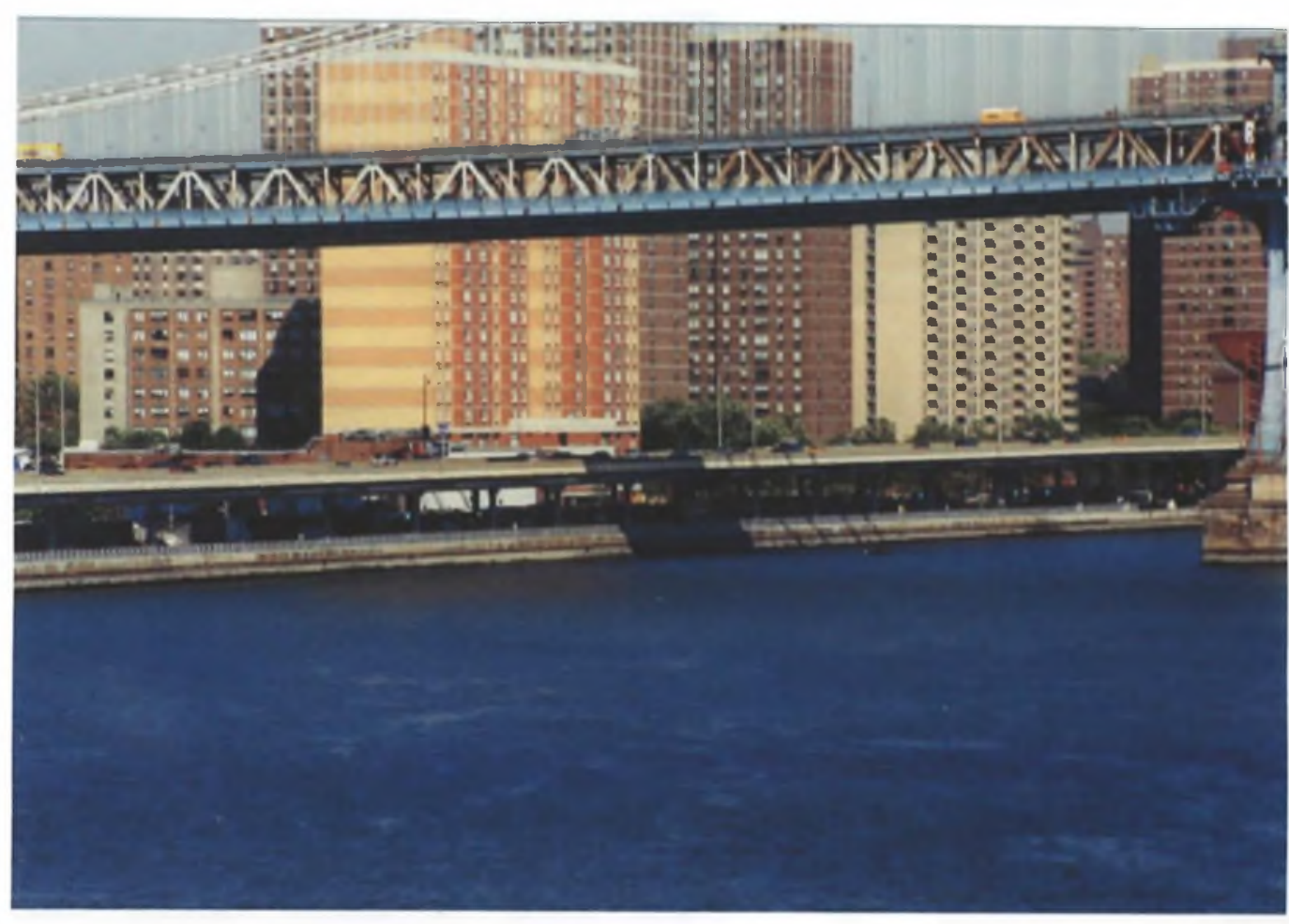

Figurc 55: FDR Drive

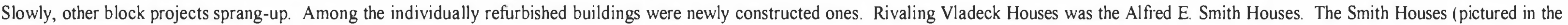

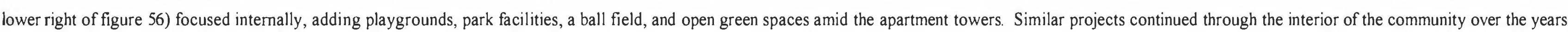

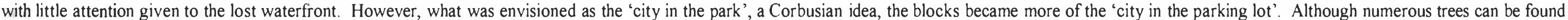
among the towers, they are creating a canopy that hides a field of asphalt and concrete firom the views above 


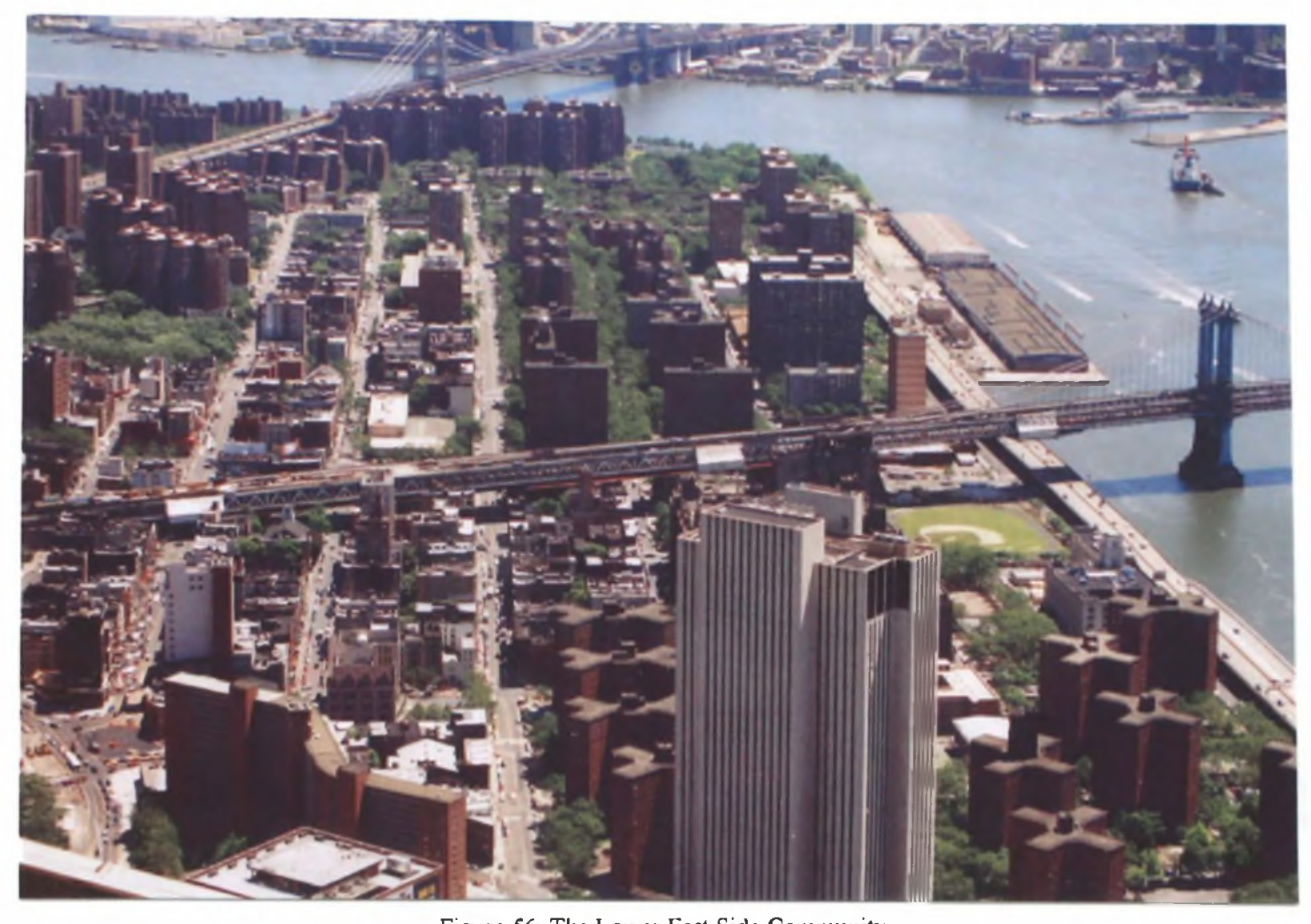

Figure 56: The Lower East Side Community

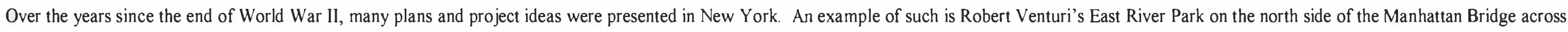

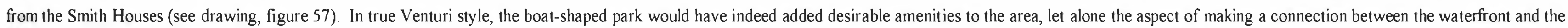

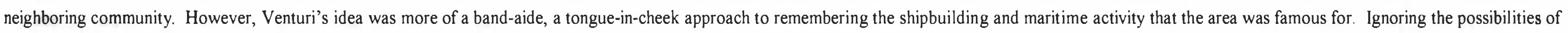

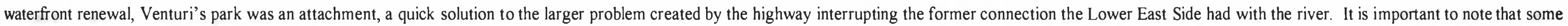
believe this project served as inspiration for Butler Rogers Baskett, and their redevelopment of the Chelsea Piers 
Figure 57: East River Park Project by Robert Venturi. 1973

The boat-shaped recreational facility, reached from shore by way of two gangplanks, was to mclude sofiball and football ficlds. baskctball courts, children's play arcas, a community garden. and cafes. "Towed" behind are a swimming pool and a lugboat. The $\$ 5.5$ milhon scheme was felled by New York's financial crisis in the mid-1970's.

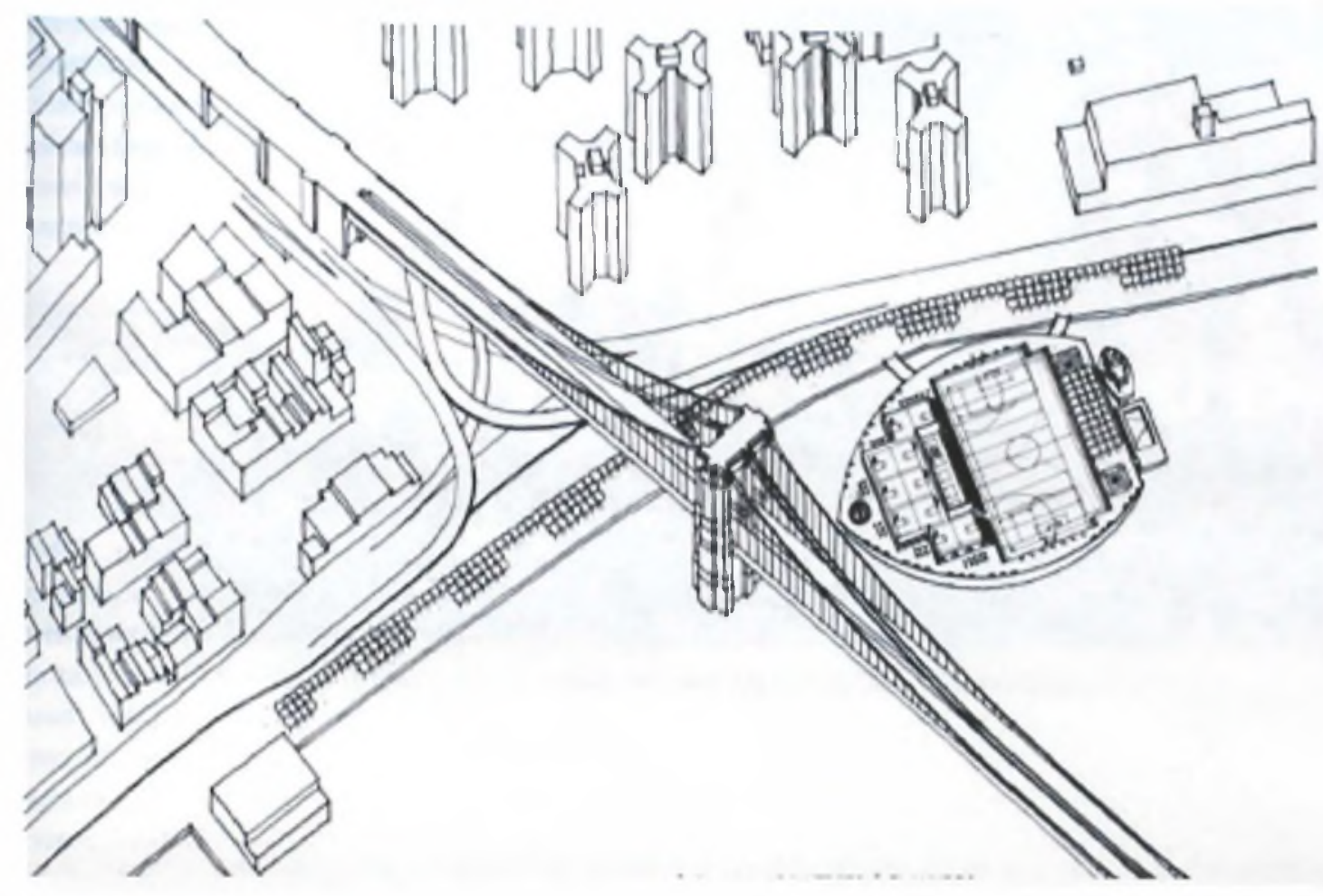

Recent Proposals and Projects Near the Lower East Side

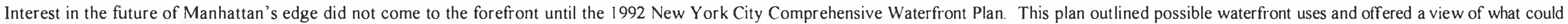

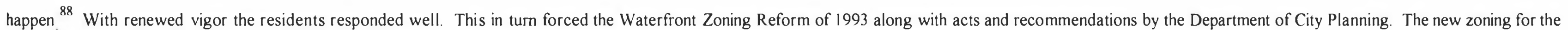

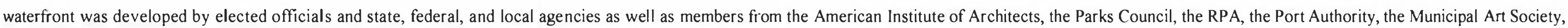
and the Real Estate Board of New York. The following is an excerpt from the Waterfront Zoning Reform

First the zoning calls for all new residential and commercial developments in medium-and high-density waterfront areas to set aside fifteen to twenty percent of their land area for publicly accessible open space Visual and physical corridors must be created or preserved to prevent the waterfront from being walled off. waterfront zoning stipulates a minimum-coverage requirement as well as height limits in order to avoid "tower in a park" designs whereby building height is out of scale with its surroundings ${ }^{89}$ 


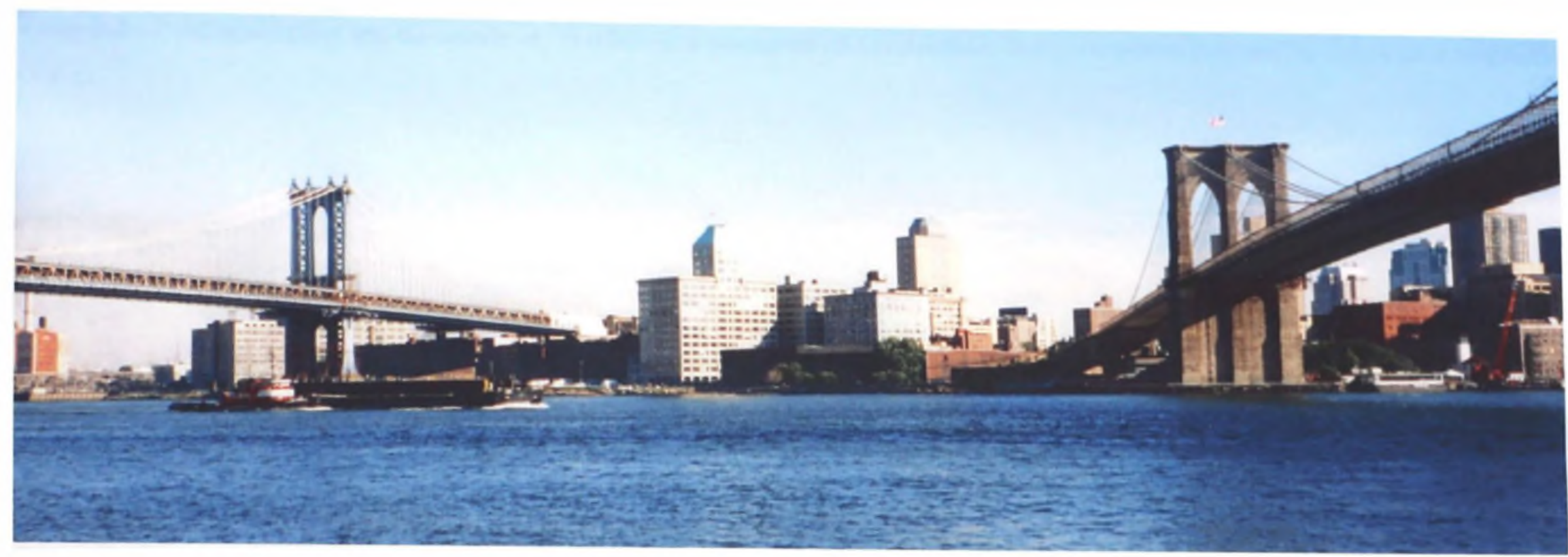

Figure 58: View of Brooklyn from the Lower East Side, between Manhattan and Brooklyn Bridges.

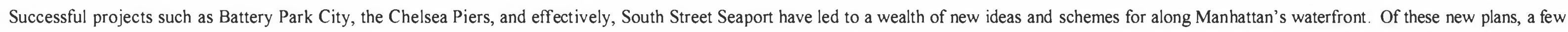

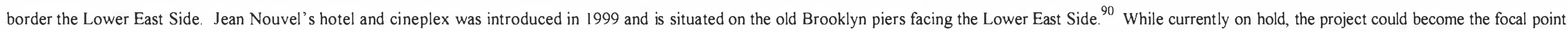

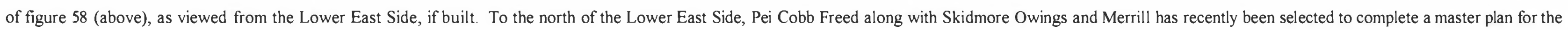

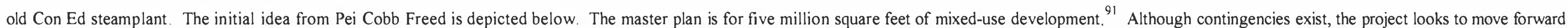
aggressively and with success

To the south of the Lower East Side, next to South Street Seaport, are two neighboring projects. In early 2000, the Guggenheim Museum unveiled Frank Gehry's latest design (pictured in figures 60 to 62). Gone from "thinking" about building it to seeking proper approvals, the new Guggenheim has secured most of the funds as well as city backing (along with $\$ 67.8$ million in city supplied financing). ${ }^{92}$ Finding itself among the elite museums of the world, the Solomon R. Guggenheim Foundation has found need to increase its presence due to its ever expanding collections. "Two years ago [1998], in light of the institution's own programmatic needs and broader debates concerning the very future and definition of museums, the architectural firm of Frank $\mathrm{O}$. Gehry and Associates was selected to participate in giving shape to a new Guggenheim Museum for New York." ${ }^{93}$ In accordance with New York's new Waterfront Zoning,
Figure 59:

Pei Cobb Freed scheme for new development on the Eas

River.

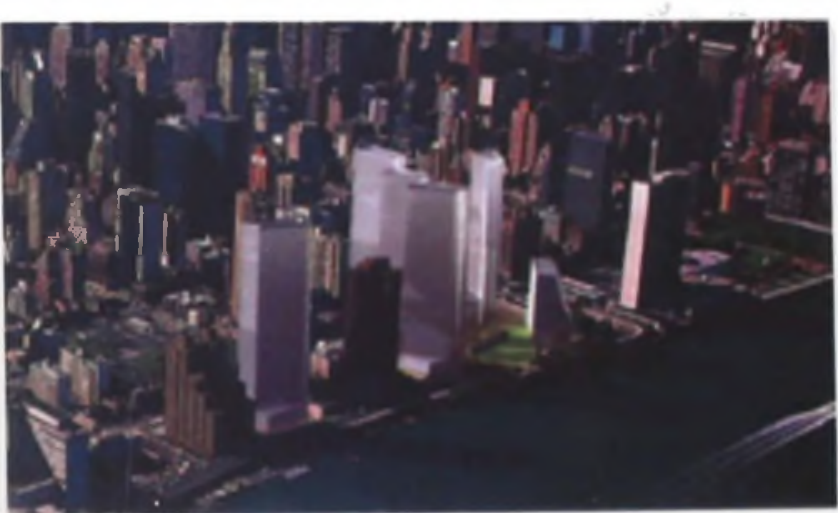




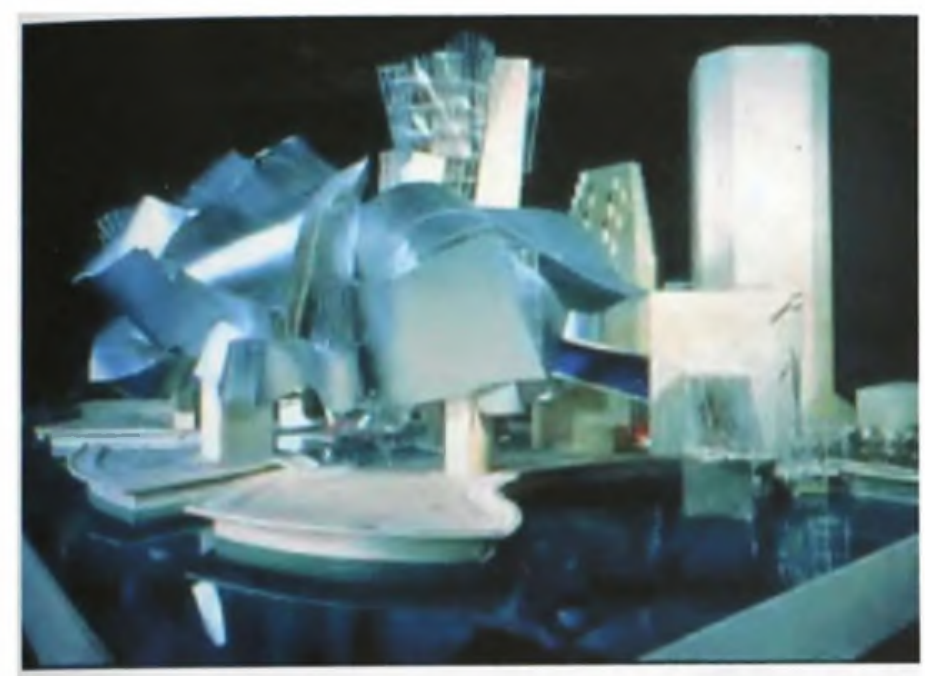

Figure 60:

Model for the new Guggenheim for New York

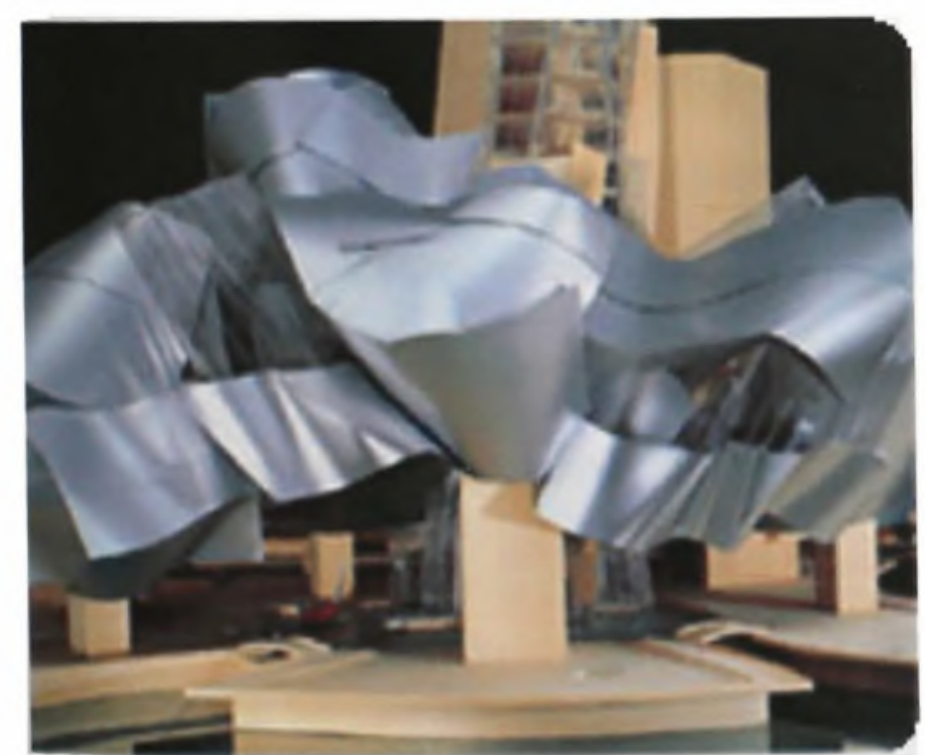

Figure 61:

Model for the new Guggenlicim for New York

Figure 62

Interior view of Geliry's Model for the new Guggenheim

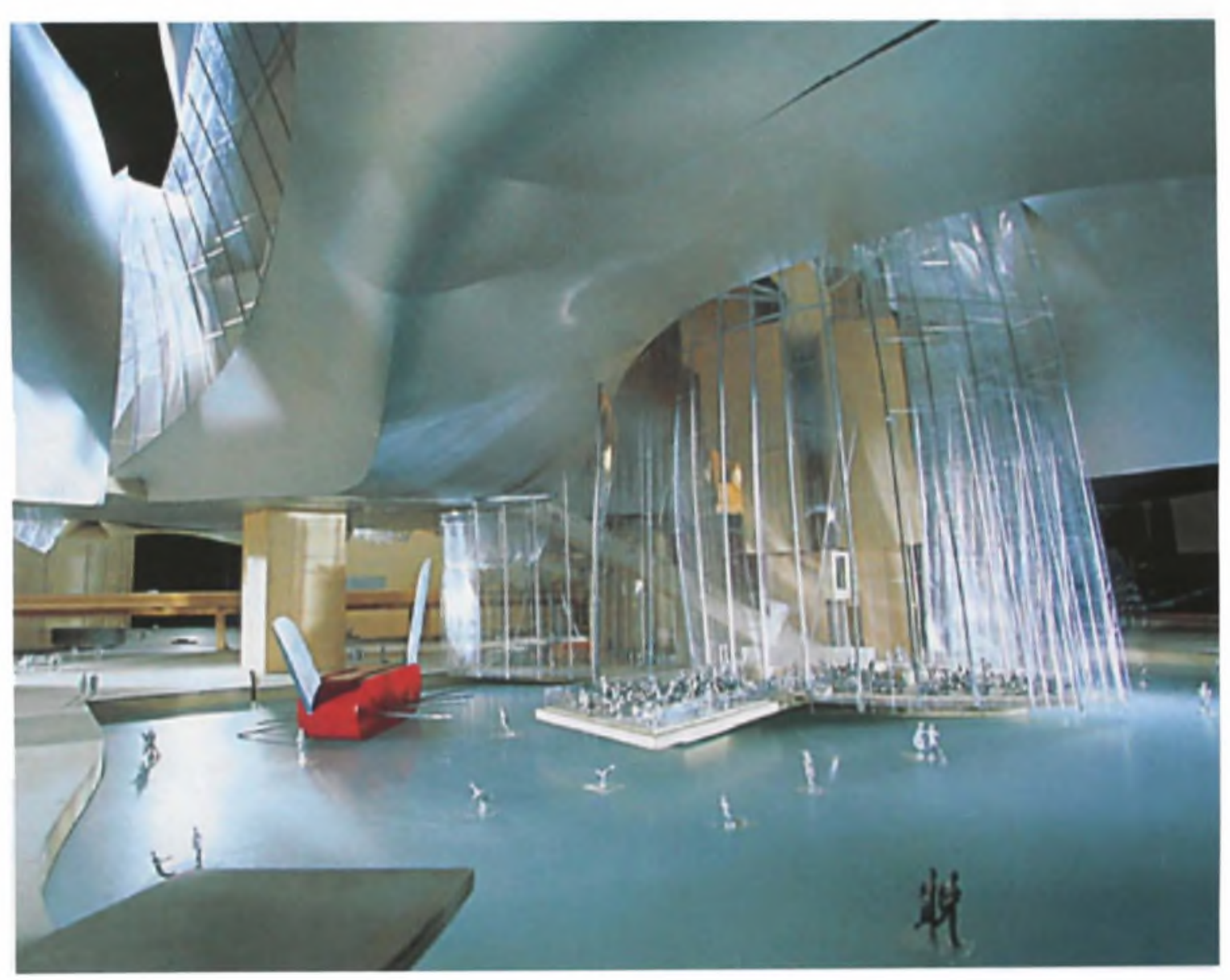




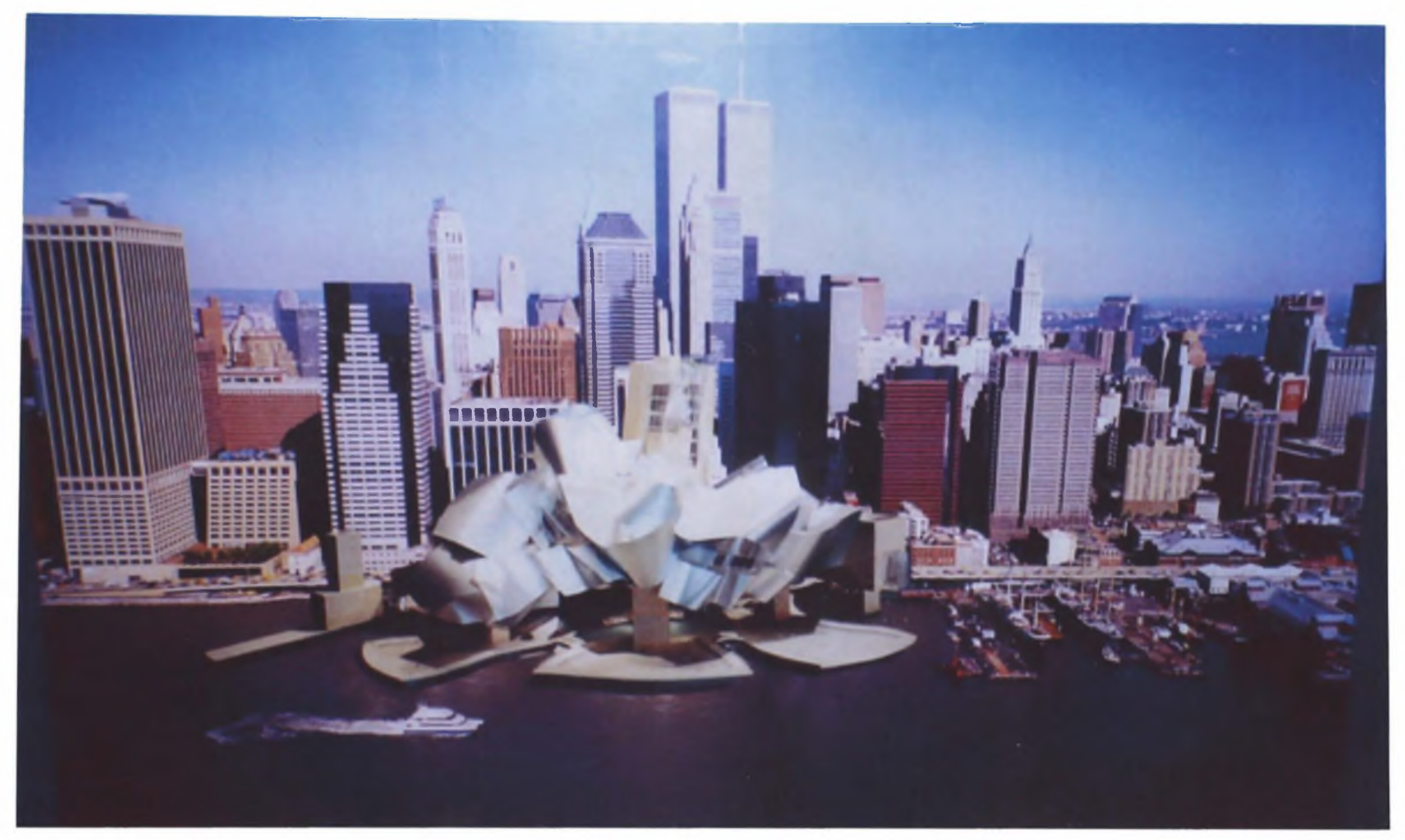

Figure 63:

Regardless of one's feelings on 'blob-itecture', Gehry's new Guggenheim would add a powerful presence to Manhattan's shore. While arguments exist on both sides of the sensitivity to place question, Gehry offers his vision. The scale of new museum correlates to the surrounding scale of lower Manhattan (as visualized in figure 63), with the ribbons softening the edges. "The rigid forms characteristic of a skyscraper-the quintessence of New York architecture-are fractured and recombined with a curvilinear body suggestive of the water's fluid movement and the energy of the city.".95 Gehry also adds that the museum's public function on the waterfront is central to its design

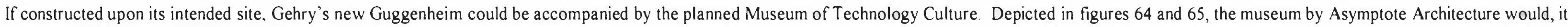

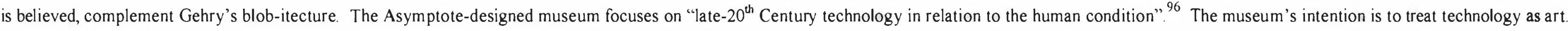

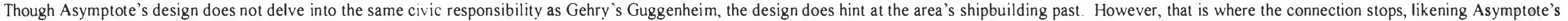
Museum to Venturi's park. 

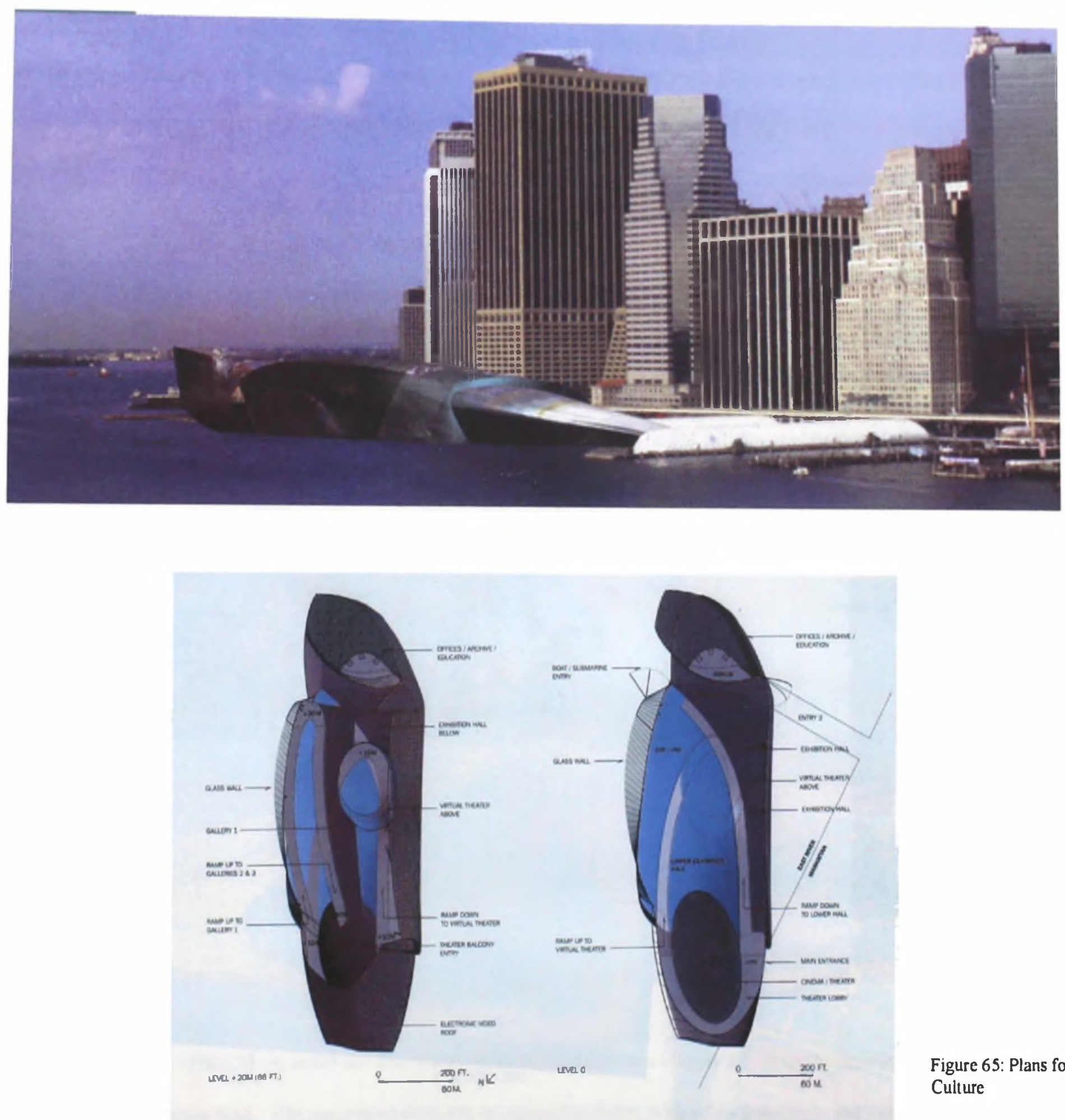

Figure 65: Plans for the Muscum of Technology Culture 


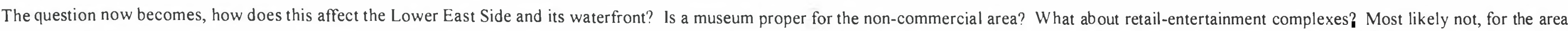

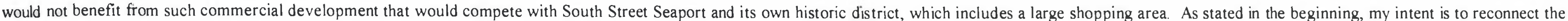

Figure 66: FDR Drive along the Lower East Side

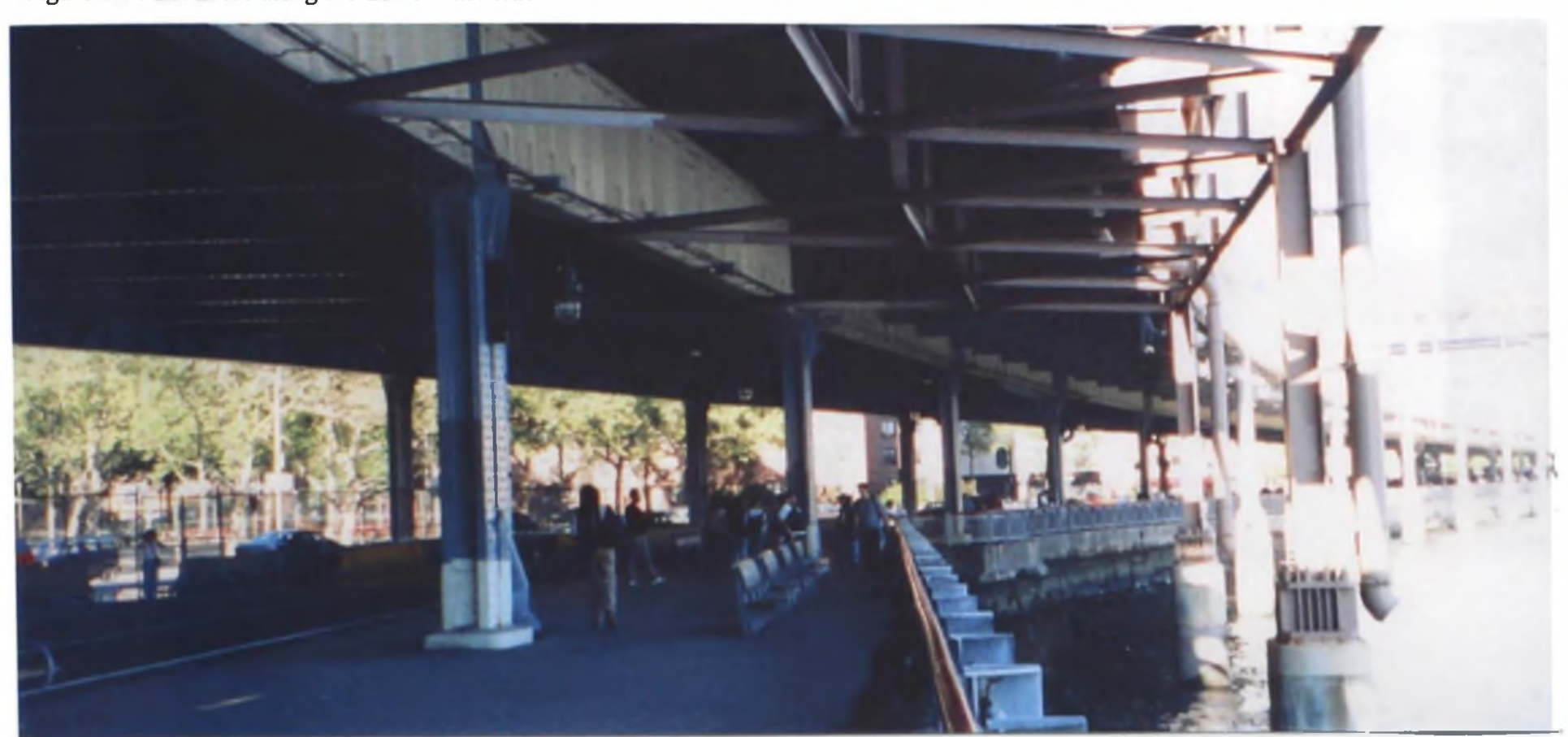

neighborhood with its now separated waterfront In the context of the Lower East Side, this reconnection is the joining, or linking, again of the community to its once thriving waterfront. As figure 66 shows, FDR Drive is a wall separating the residents from their waterfront. Even with the addition of the bike and pedestrian path, the elevated highway restricts access to the water. Additionally, the space under the highway has become one long parking area (mostly for the city's D.O.T. vehicles), and is enhanced by the chain link fence separating it from the surface street (figures 66 and 67).

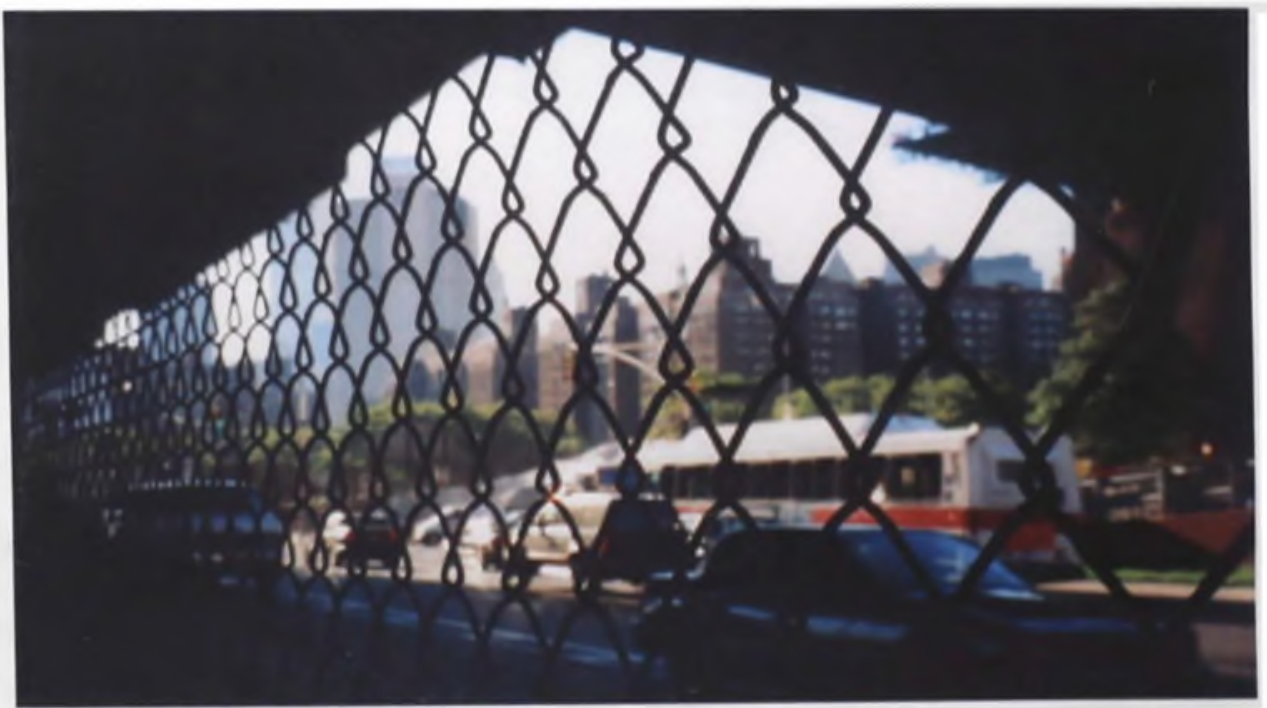

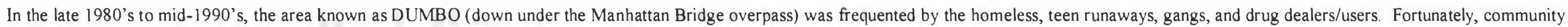

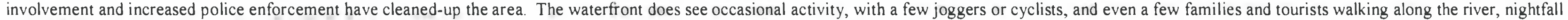

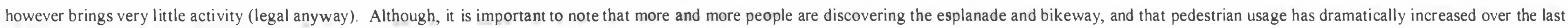
few years. ${ }^{97}$ 


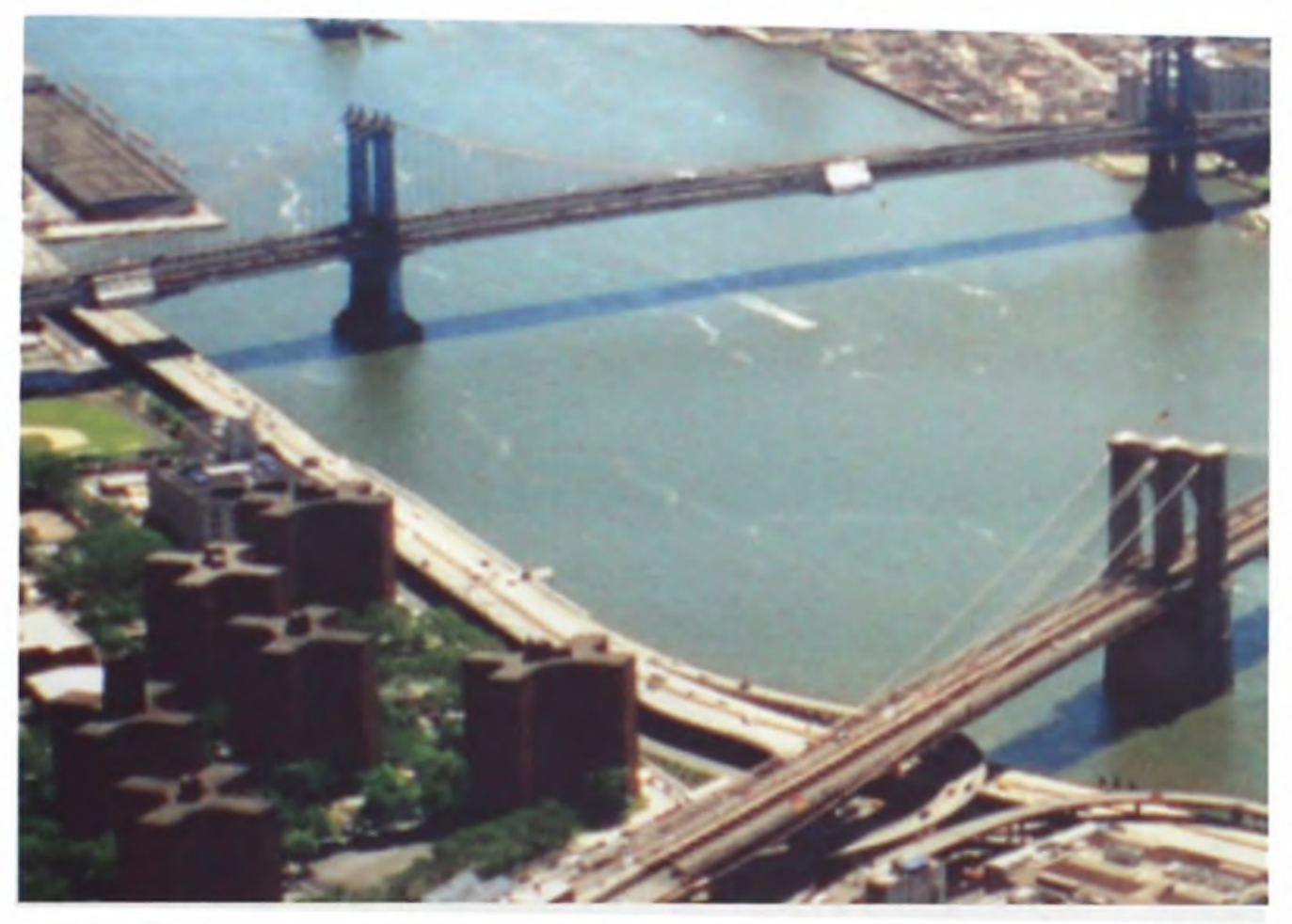

Figure 68

The Lower East Side between the Marlhattan and Brooklyn Bridges

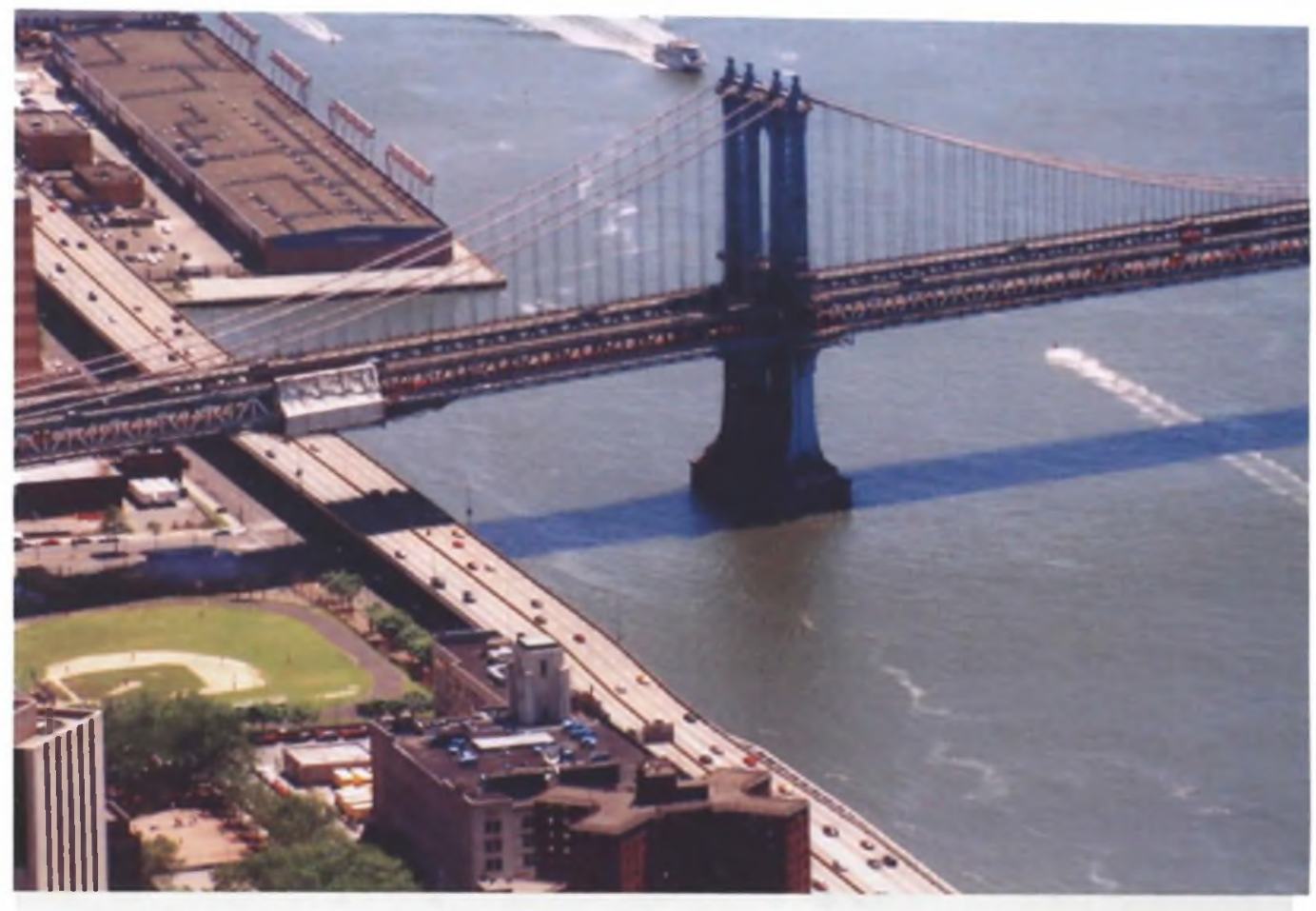

Figure 69

Thesis Project Introduction

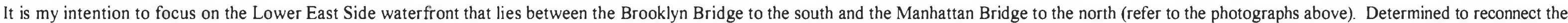

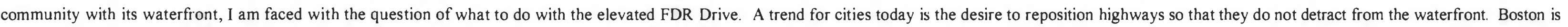

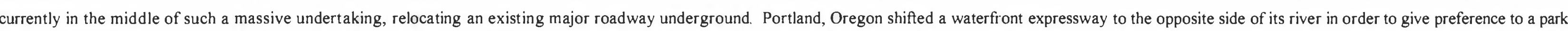

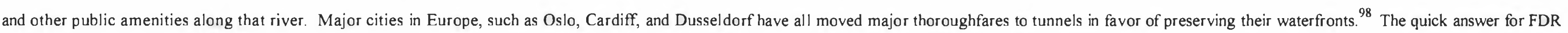

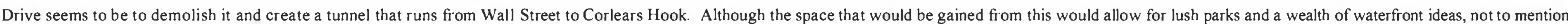

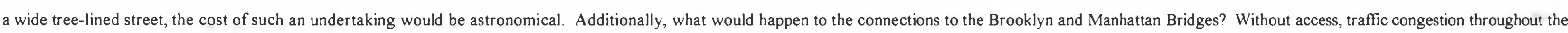
area would get much worse. Likewise, the surface streets would again become clogged and unsafe 


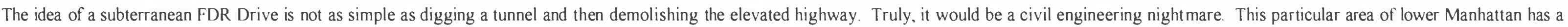

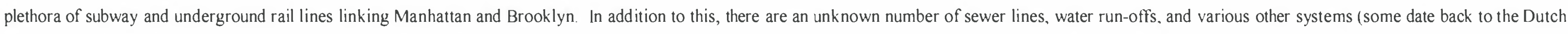

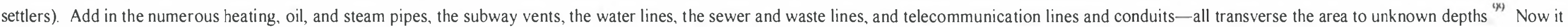

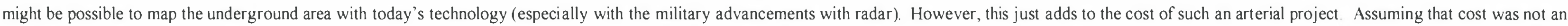

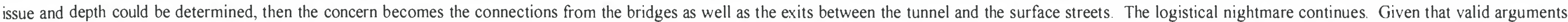
can be made for and against a tunnel-ized version of FDR Drive, there are other possibilities worth examining

Figure 70: The elevaled FDR Drive

Note the remains of the old picr slructures along the bulkhcad

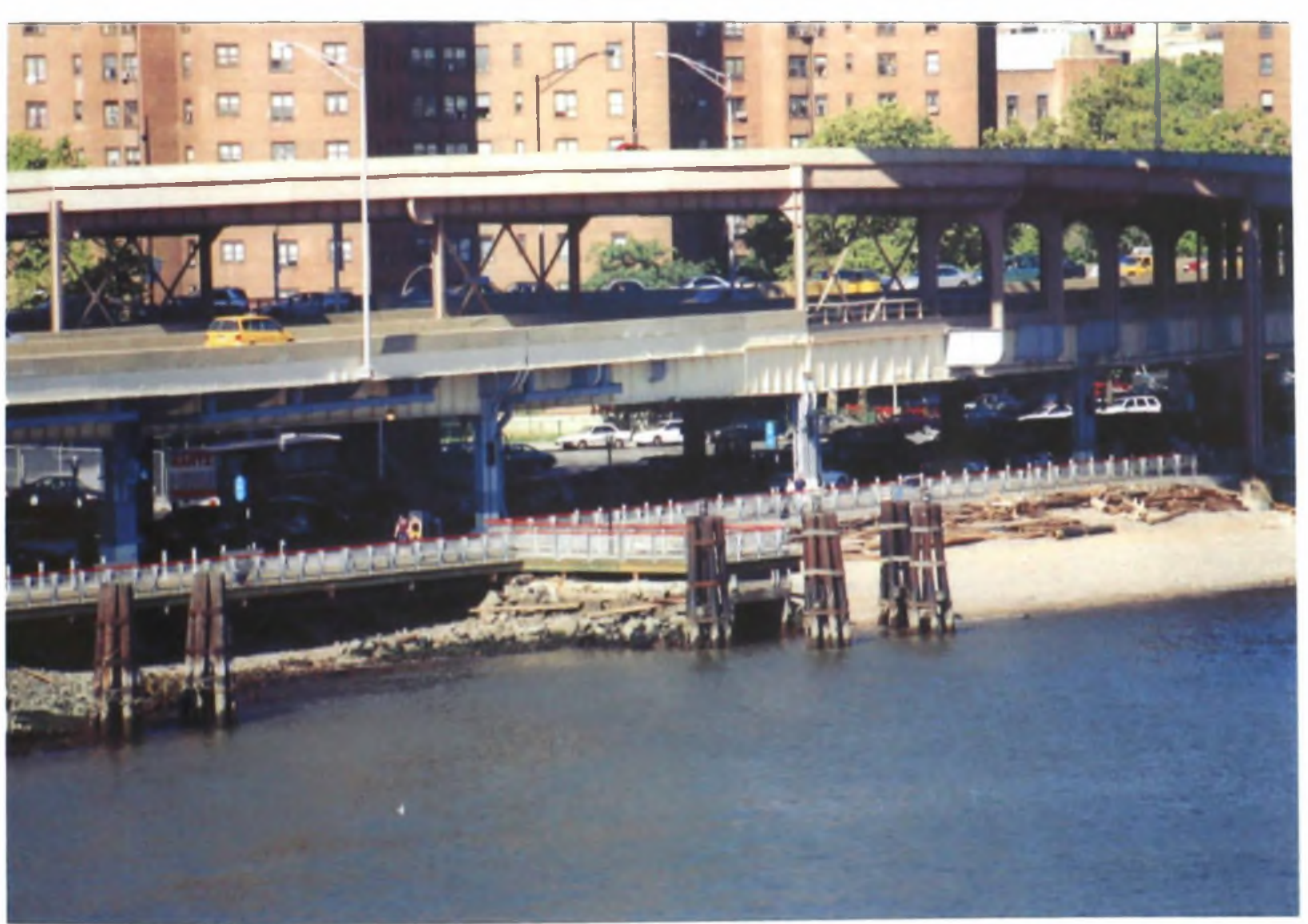

Creating a Robert Moses era parkway seems like a suitable alternative. Like it was originally planned, a wide landscaped surface boulevard in lieu of the elevated highway would not only allow for vehicular travel but would also maintain the connections to the bridges. Pedestrian walks on both sides of the parkway, along with elevated crossovers would increase access to the waterfront and allow for visible and physical corridors. Without question, a divided roadway with landscaping would add a sense of community to the area and would visually reconnect the waterfront. Likewise, the existing bike esplanade could be reconfigured into one long continuous greenspace, connecting Pier 17 to Corlears Hook and the East River Park. However, would traffic congestion increase? Tree-lined boulevards are historically credited with slowing traffic, and this would cause commuter problems for New Yorker drivers. With slower speeds and stoplights associated with a surface road, traffic congestion would increase during the commuter rush hours and peak delivery periods. This in turn may be detrimental to the pedestrians attempting to access the waterfront or esplanade (unless elevated crosswalks are added). Though it has concerns, a surface level FDR Drive does work for New York, which is evidenced near Corlears Hook where the Drive becomes a surface street as it continues northward. So then the debate is over who takes precedent - the commuter or the community?

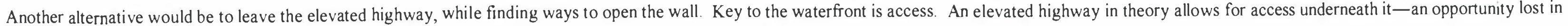

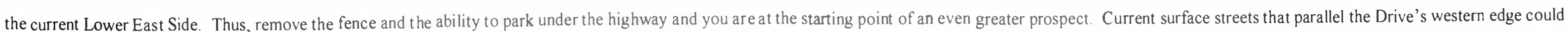




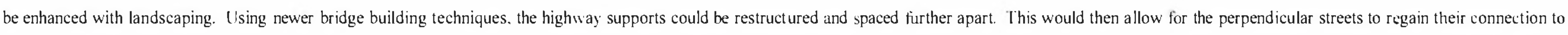

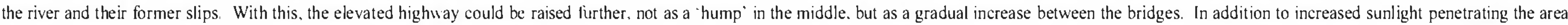

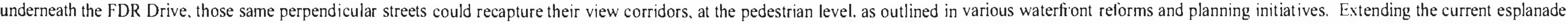

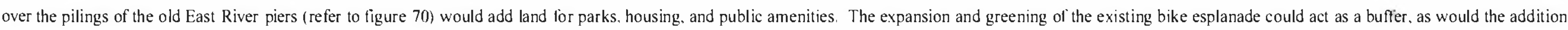

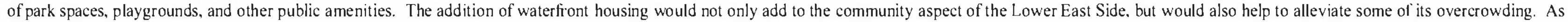

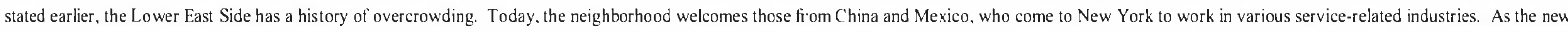

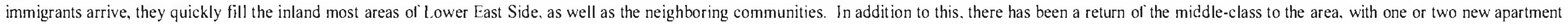

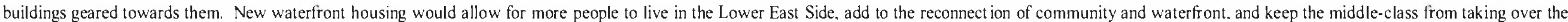
older apartment buildings (forcing lower income people out), It would add a balance

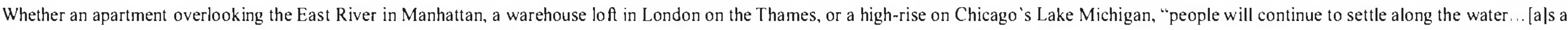
consequence, the tension between private and public interests with respect to that most public of resources will continue and most likely, increase as communities seek to redevelop their waterfront", ${ }^{100}$

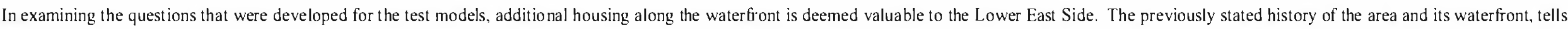

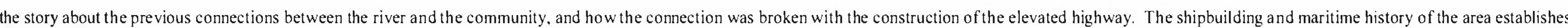

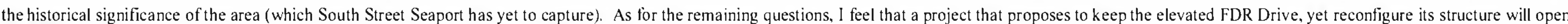

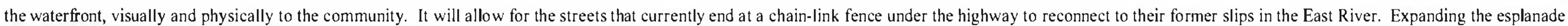

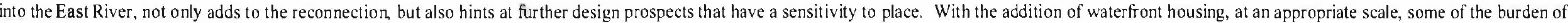

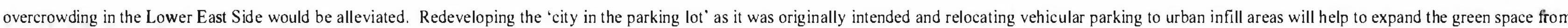
the river's edge to the entire Lower East Side. With this, I conclude that such a proposal would indeed reconnect the Lower East Side with the East River. 


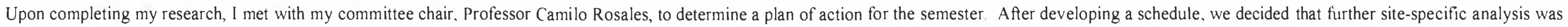

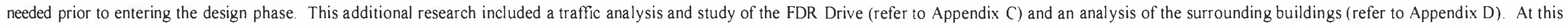

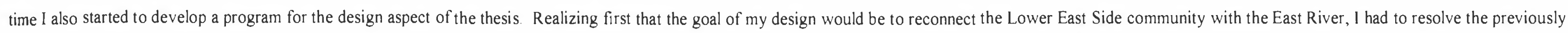
recognized problem-FDR Drive

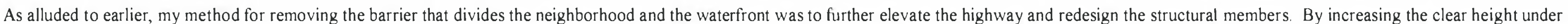

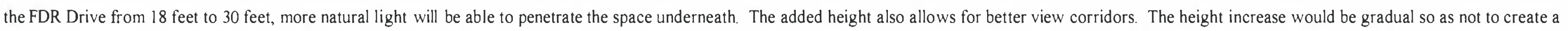

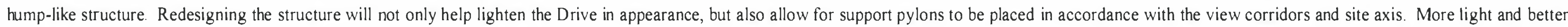
views will increase access to the waterfront and thus the East River will be perceived as being closer to the neighborhood.

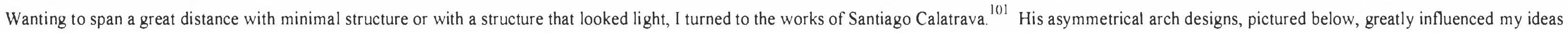

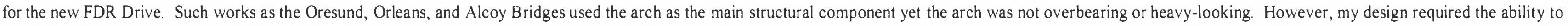

Figure 66: The Oresund Bridge

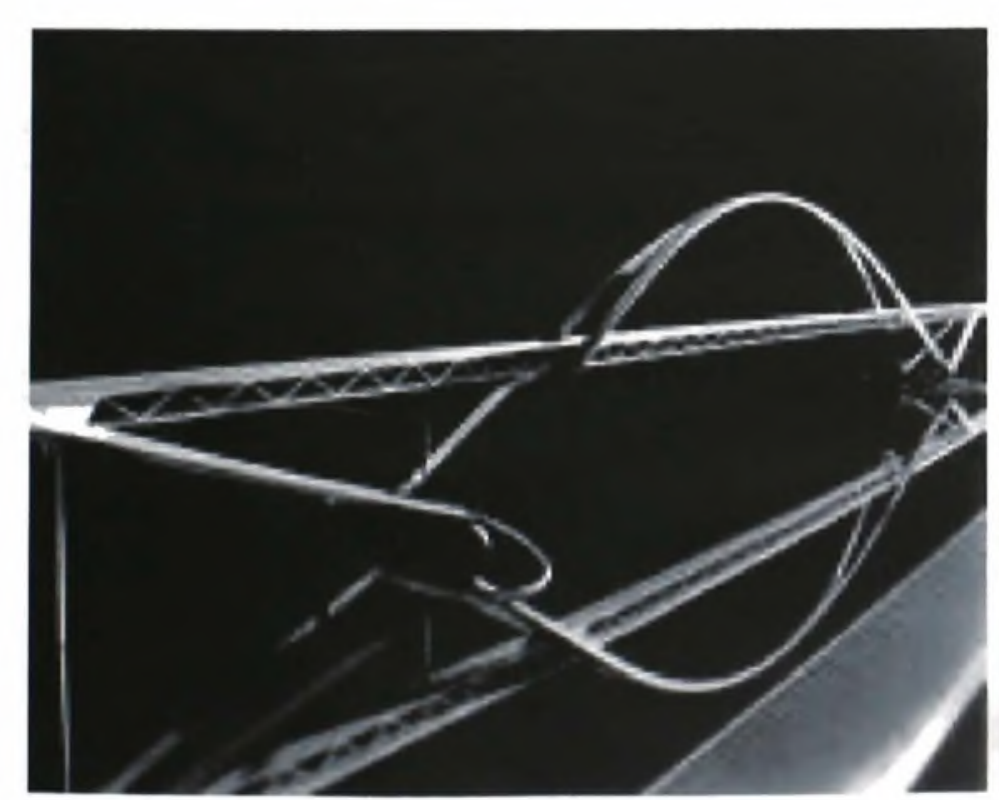

Figure 67: The Orleans Bridge

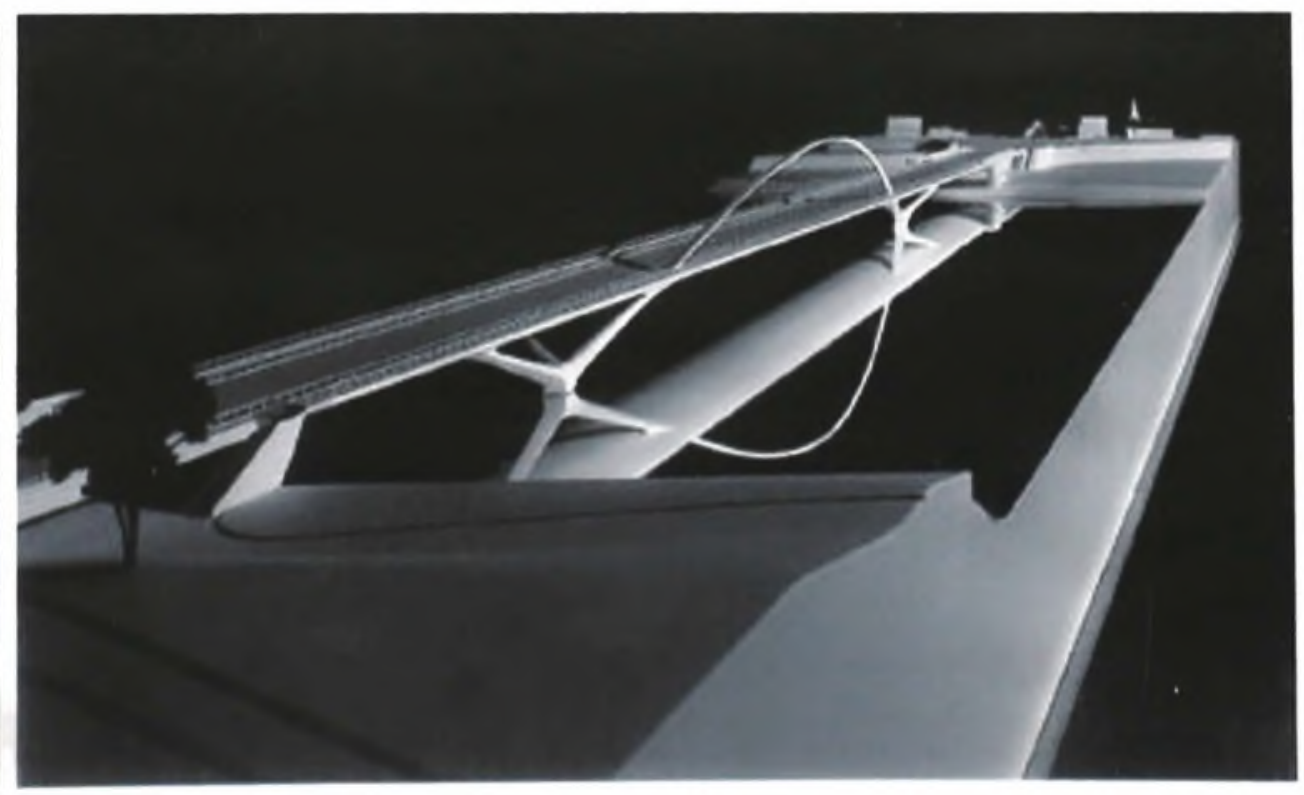

Figure 68: The Alcoy Bridge

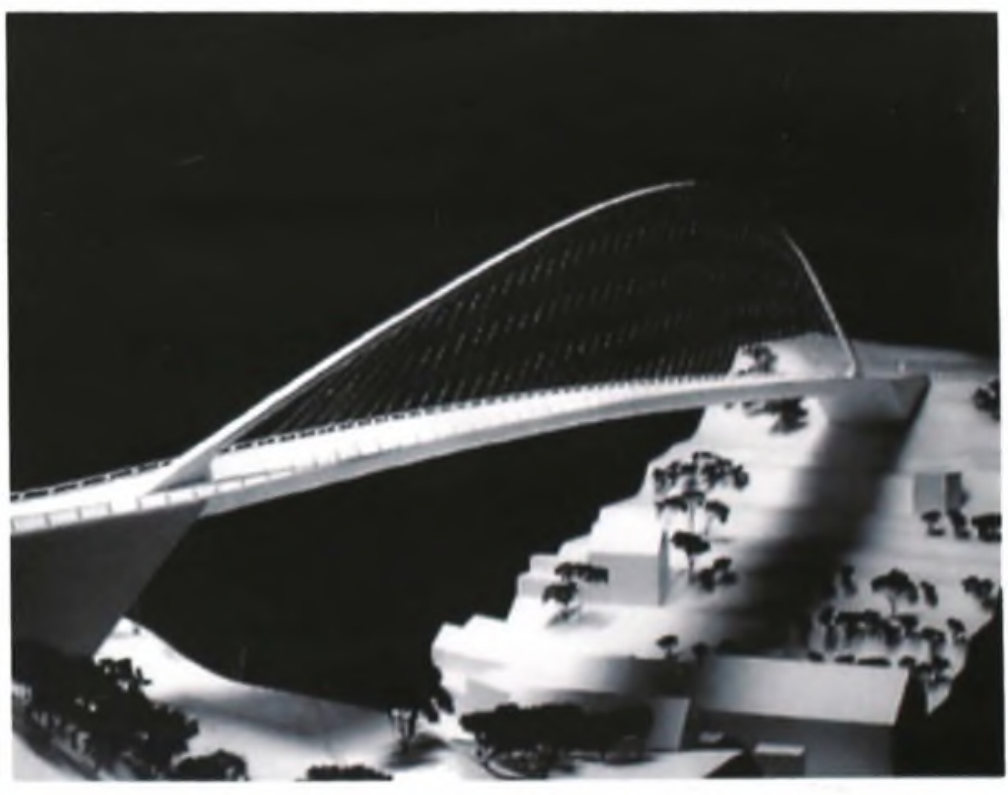


Figure 69

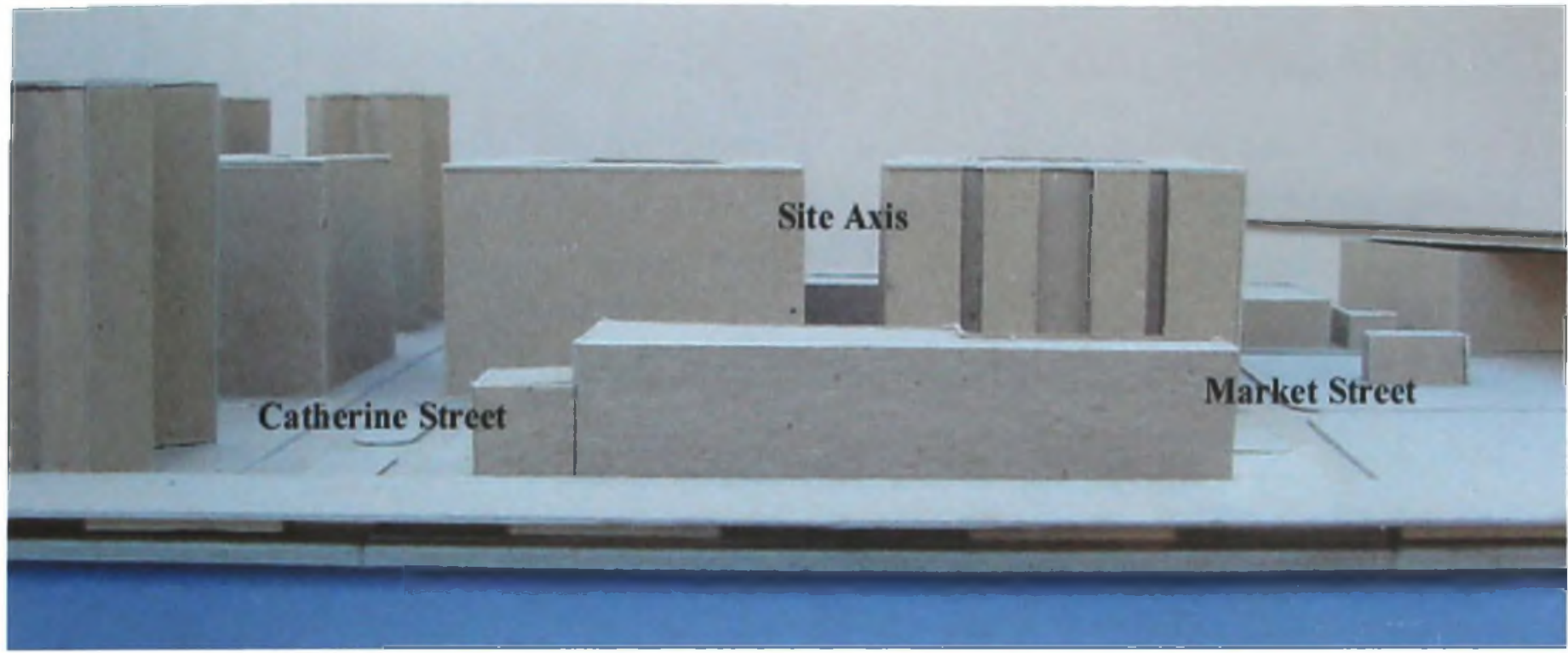

Figure 70: Calatrava's Eas London River Crossing

After designing a triple arch system with a secondary space frame for road surface support, I sought the advice my third committee member, structural engineer Luke McGregor. At first he was unconvinced that I could span such a

distance. However, once he studied the structural designs of Calatrava's bridges, he felt confident that such a design would work. Shown in elevation on the next page, the design consisted of three asymmetrical arches. The central arch spans 640 feet, is angled $60^{\circ}$ to the east, and peaks at 60 feet above the street level. The north and south flanking arches each span 320 feet and are angled $60^{\circ}$ to the west. These two arches peak at 45 feet above street level. Figures 72 and 73 show a partial rendering of the road surface support spine, designed to relieve torsional loads
While starting to develop an asymmetrical arch design for my project, 1 discovered Calatrava's design for the East London River Crossing, pictured in figure 70 below. The span of the arch is over 900 feet yet was shallow at only 75 feet Additionally, the distance between the abutments was over 1,500 feet

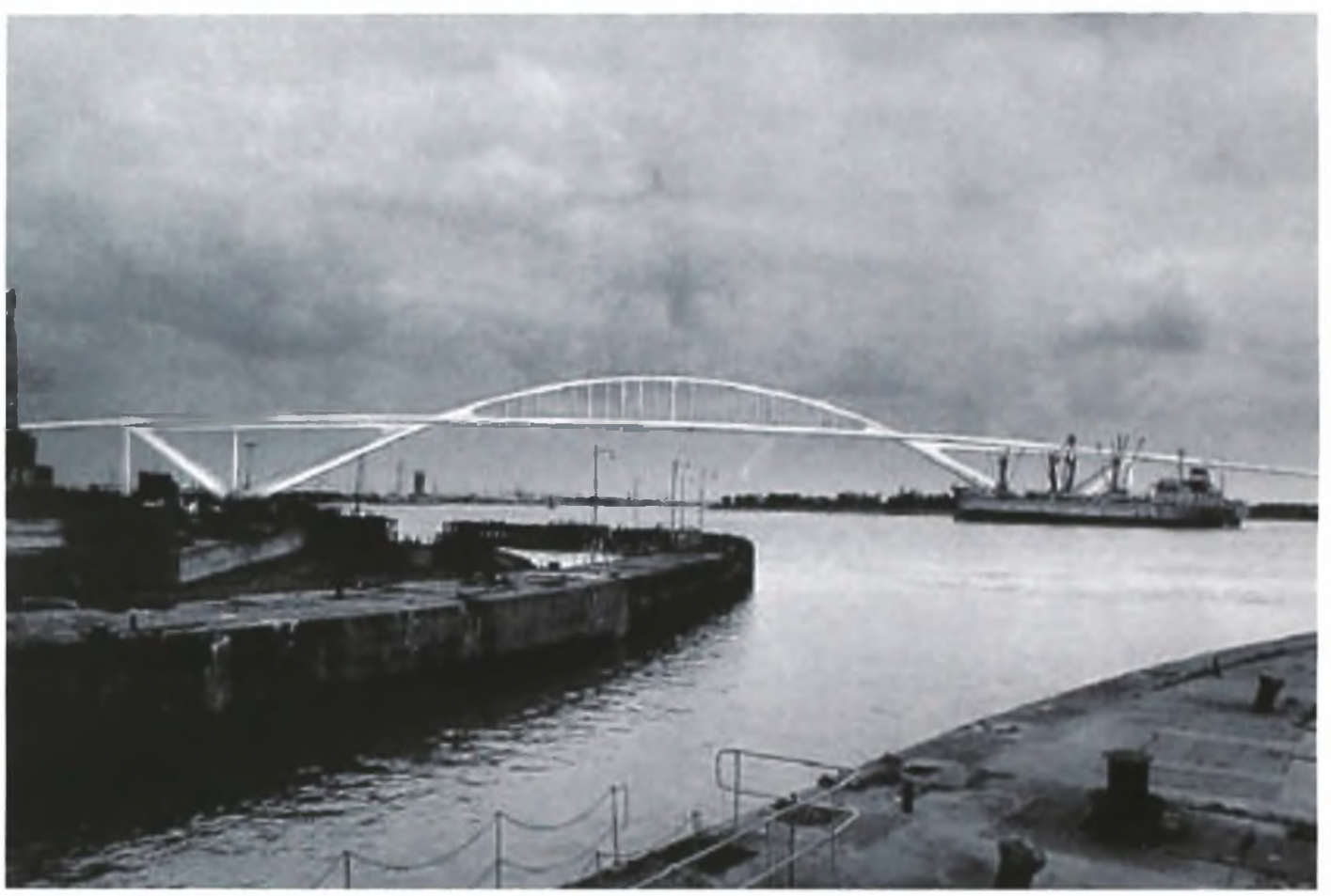




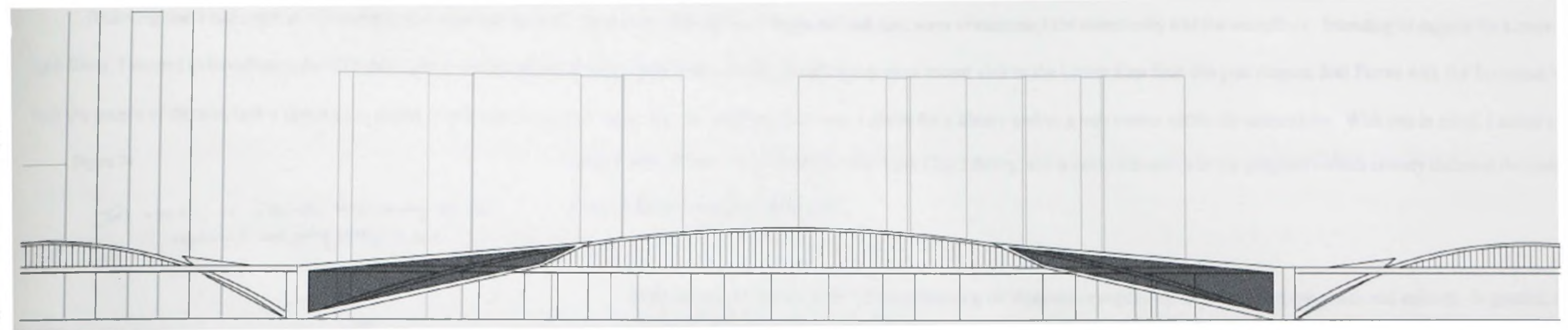

Figure 71
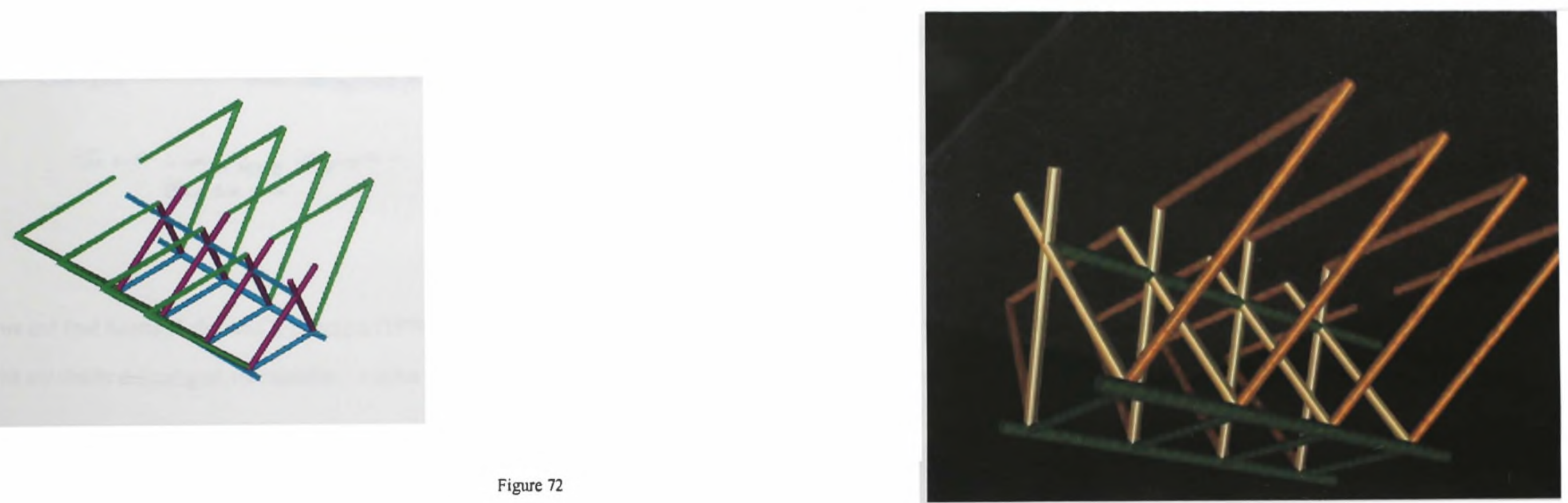

Figure 73

Figure 72 


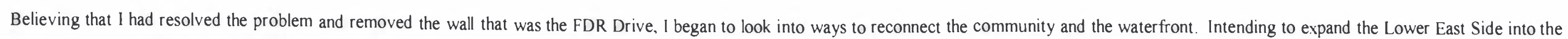

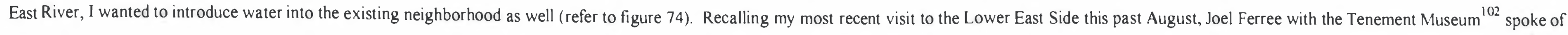

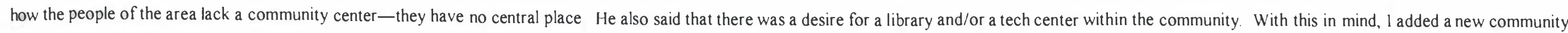

Figure 74

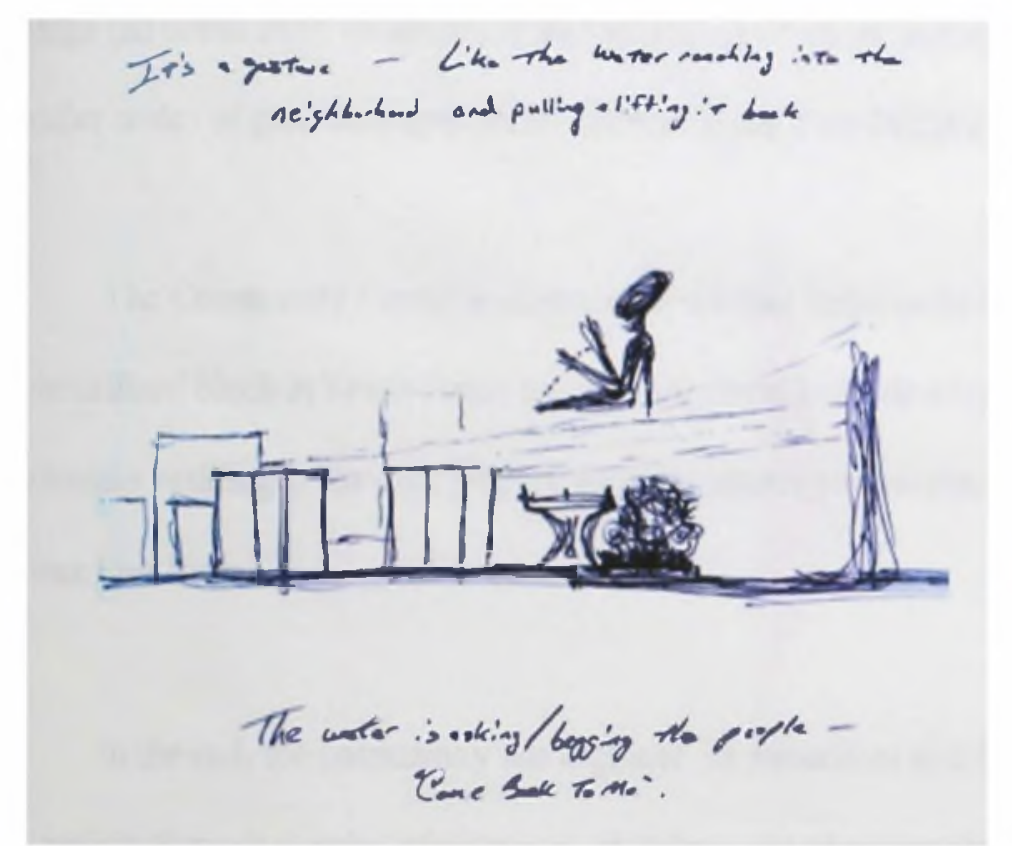

center with offices, a branch of the New York City Library, and a computer center to my program (which already included the newly designed FDR

Drive and the expanded esplanade)

Midterm review was positive yet the scattering of ideas and components required me to step back and refocus. In general, the comments made by Professor Rosales, Professor Marilys Nepomechie, and Luke McGregor were positive, however, we all agreed that each component—the FDR Drive, the parks, the esplanade, the community center, the waterfront—could each become their own design project. My thesis, my goal, is about reconnection. How to reconnect the Lower East Side to its former waterfiont? My role as designer was one of urban planner and this was as urban design project. I was told to not get caught-up in the details of designing every little aspect, but to redesign and reconnect the community. Yes, FDR Drive was a part of this, a very necessary step, but I am not to concern myself with every element of its design. There are many issues within the existing site context and that is where 1 should refocus my design

With the few weeks that remained, I assumed the role of urban designer. On the suggestion that I read and take notes on Collage City (1978), by

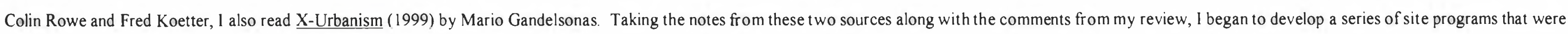

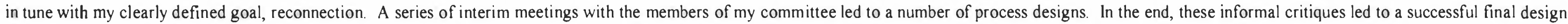

The Thesis Design Project

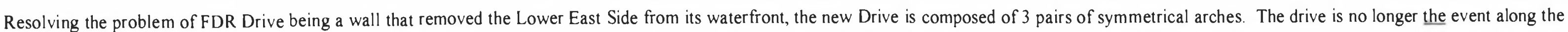

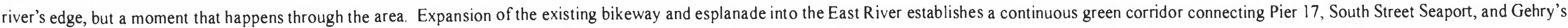

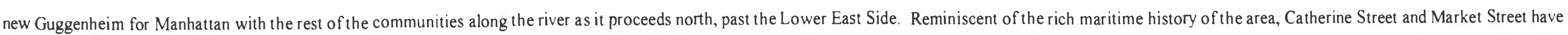

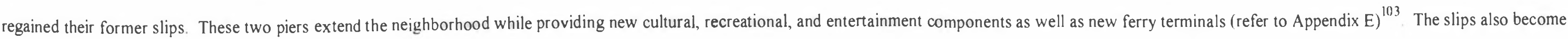




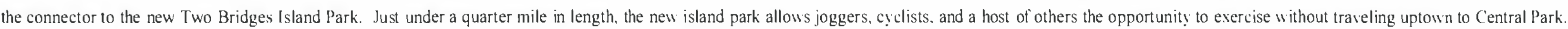

The island park also has the space to host a variety of venues from festivals and art fairs to outdoor concerts.

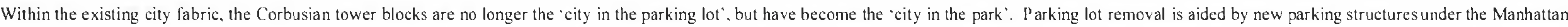

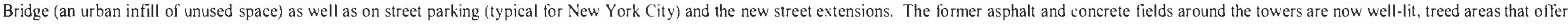
smaller nodes of park atmosphere and connect to the Two Bridges Island Park.

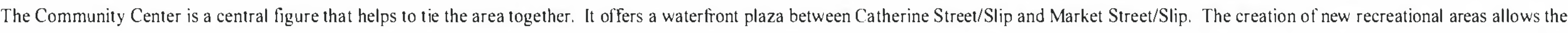

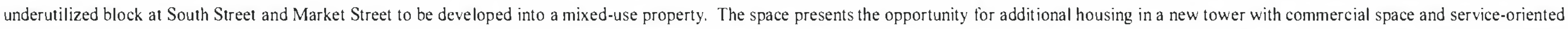

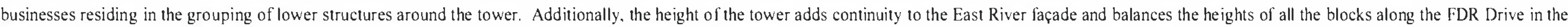
Lower East Side.

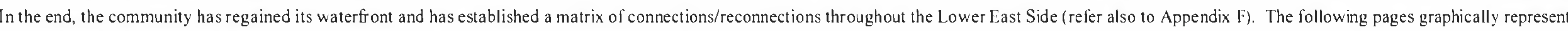
the project through a series of drawings, sketches, site photographs, model photographs, and photomontages. 

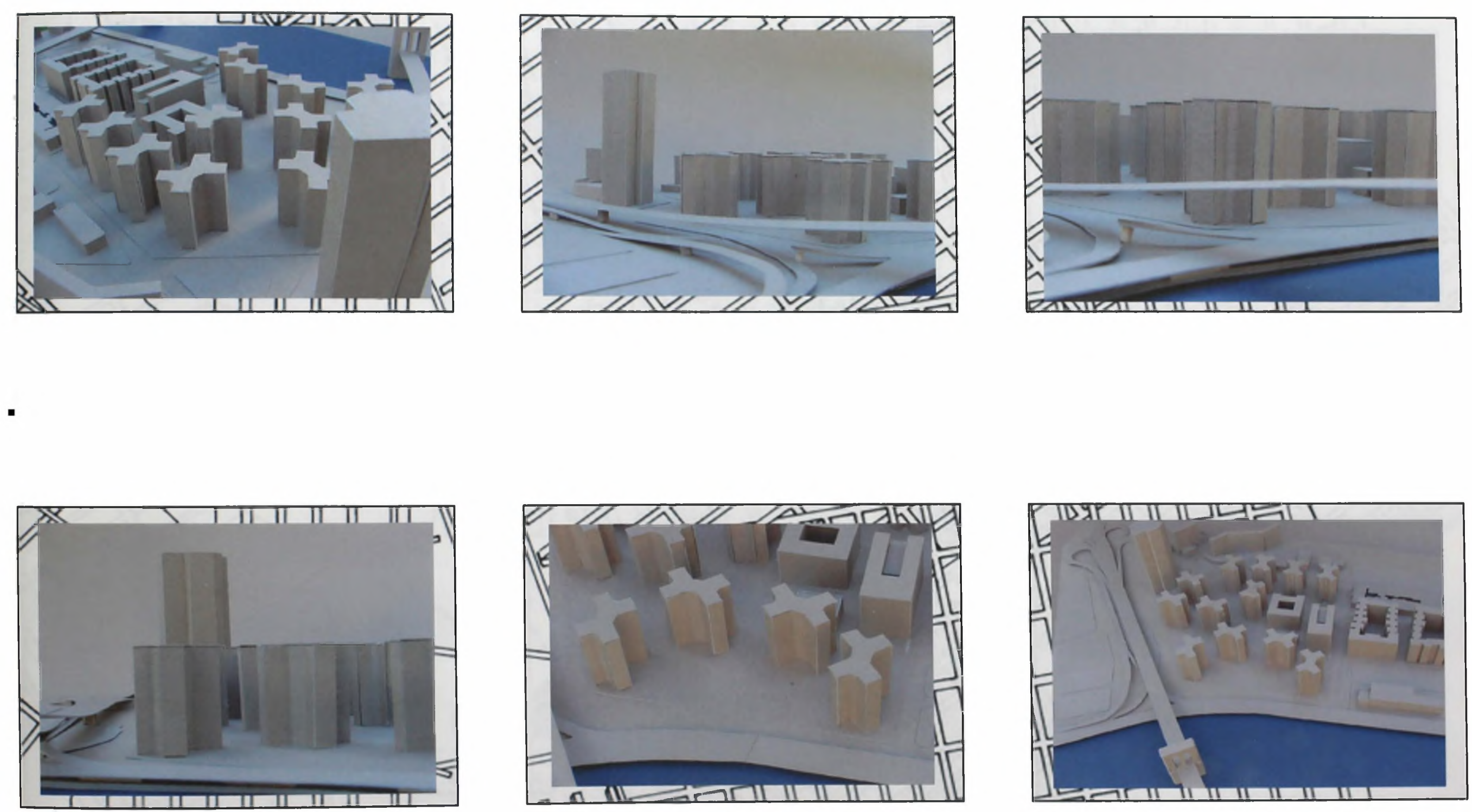

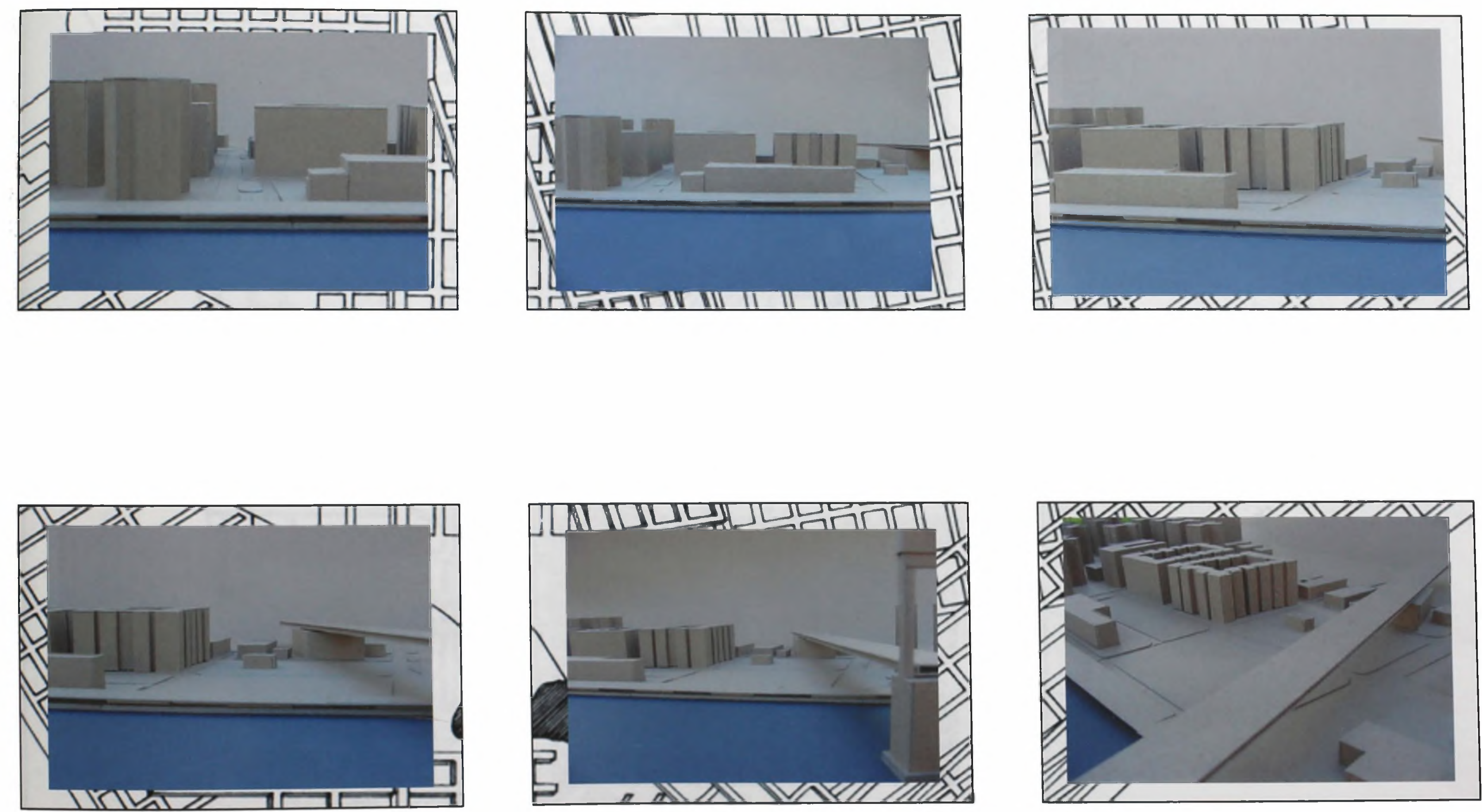

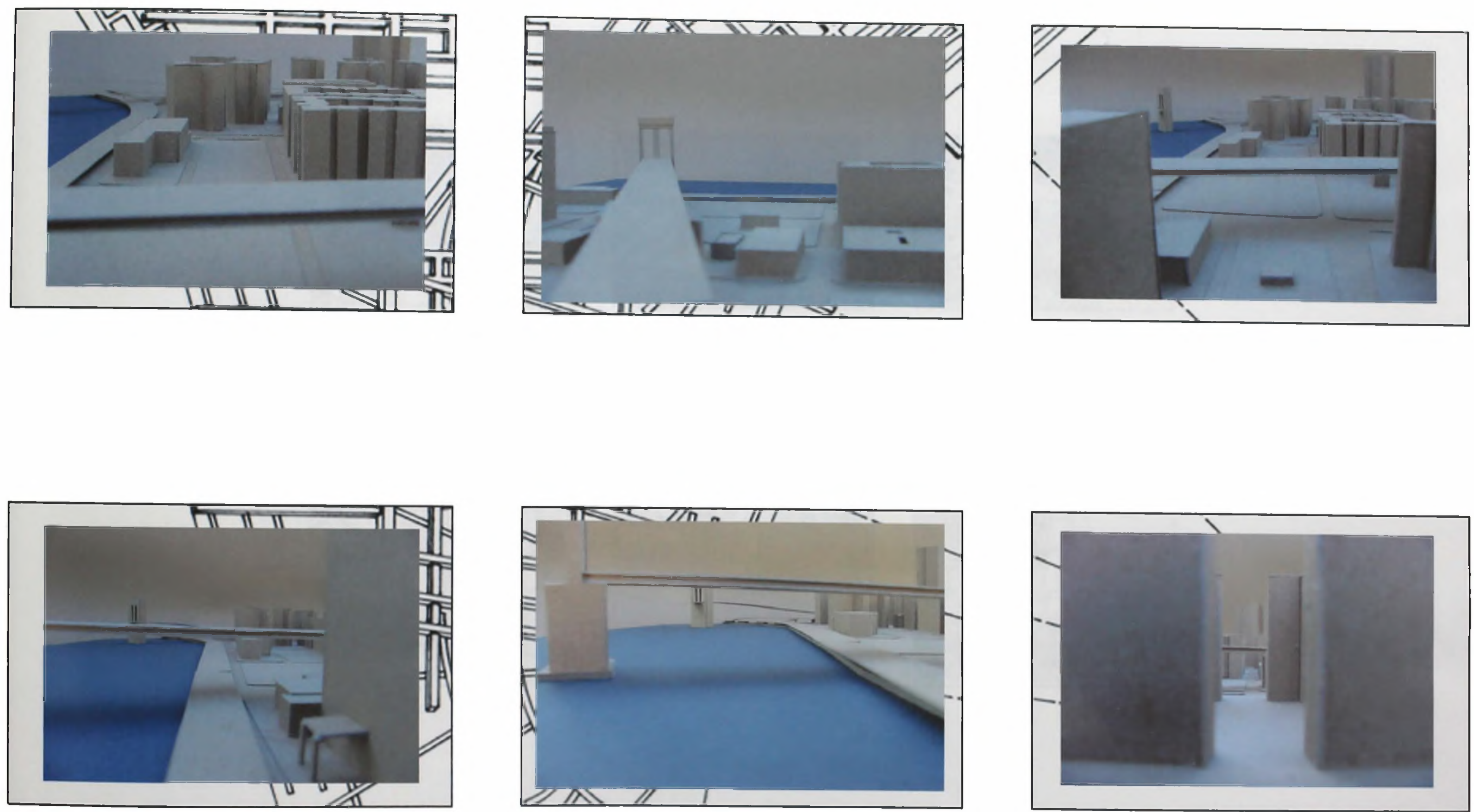

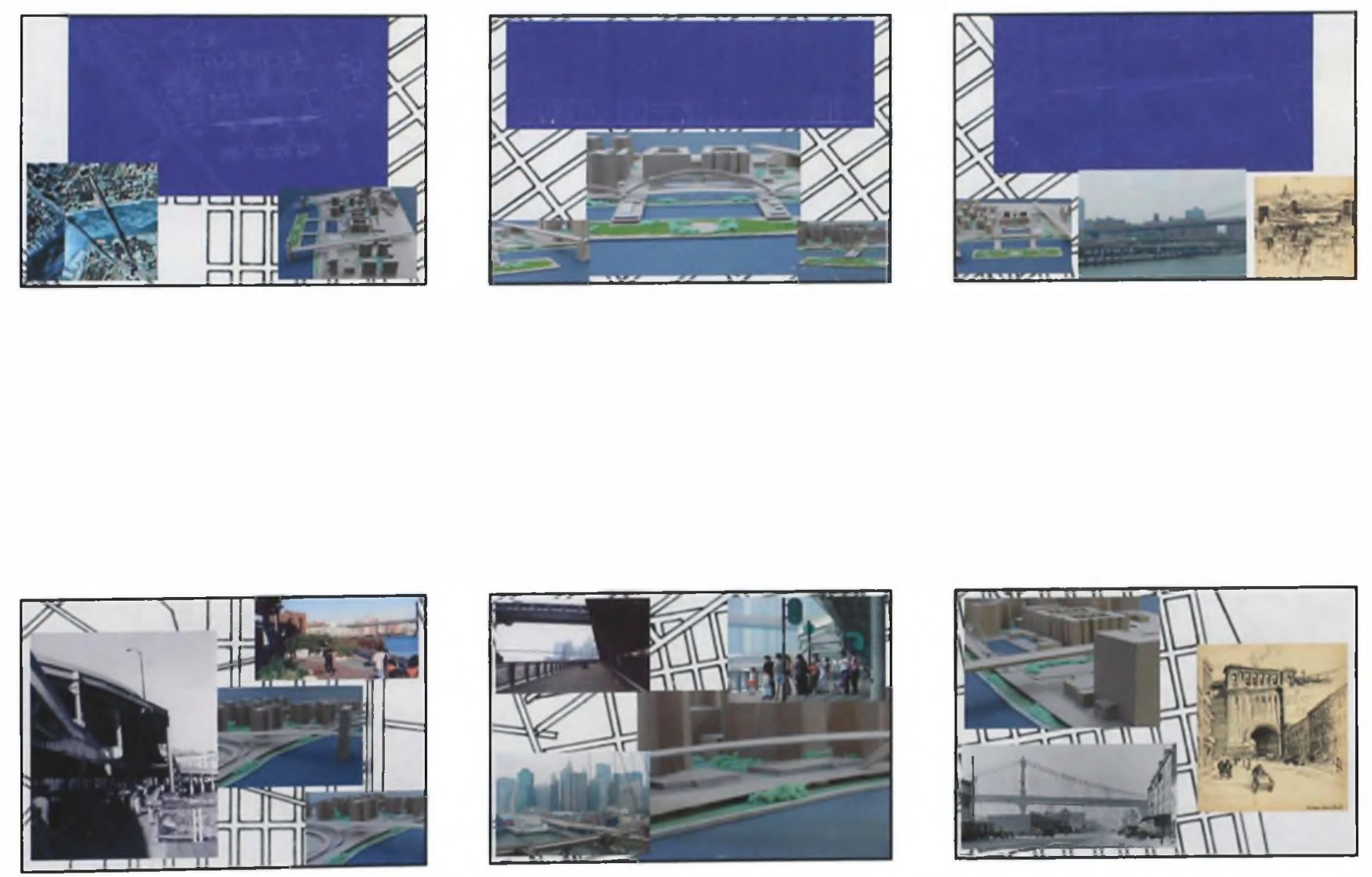

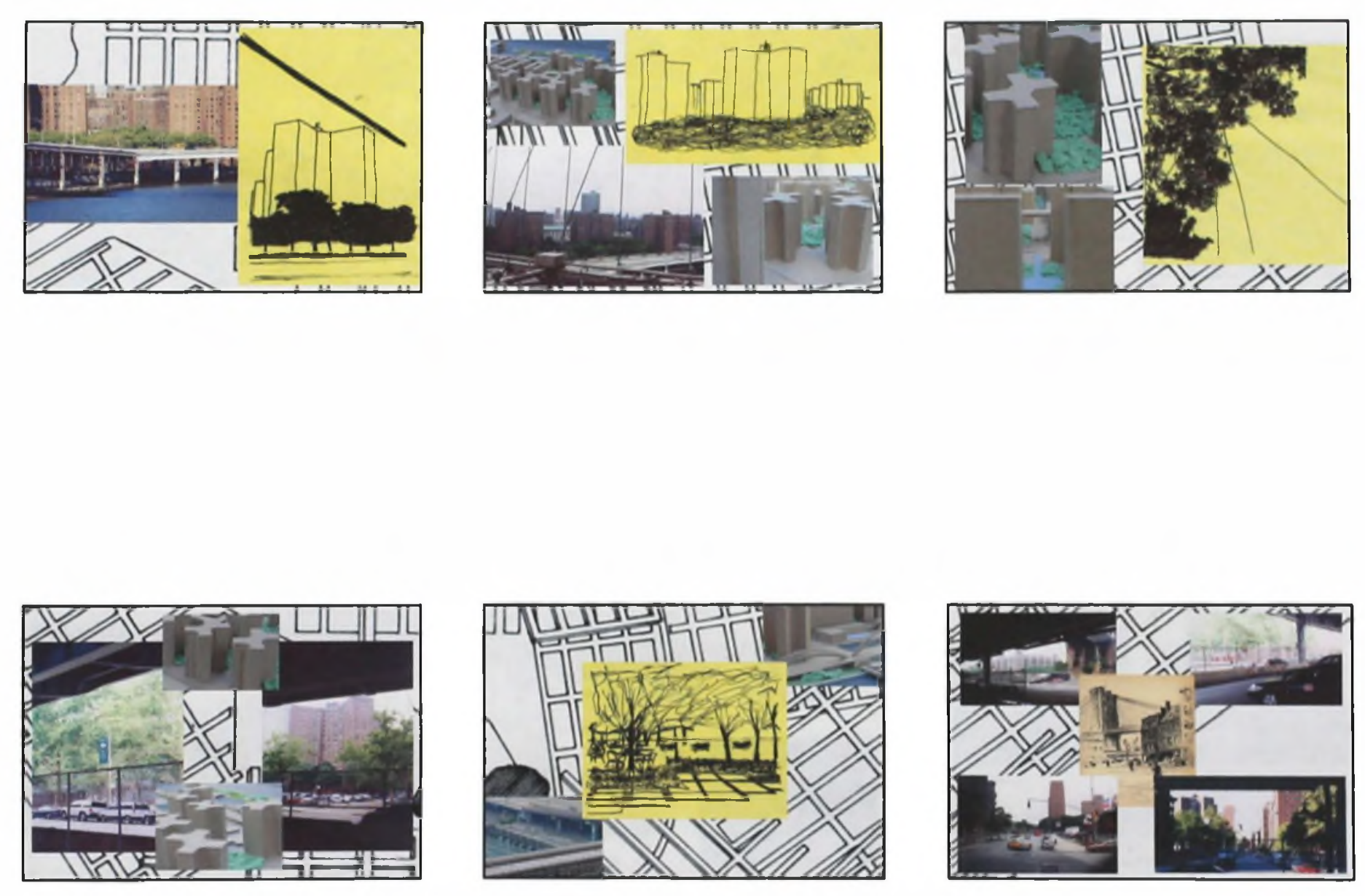

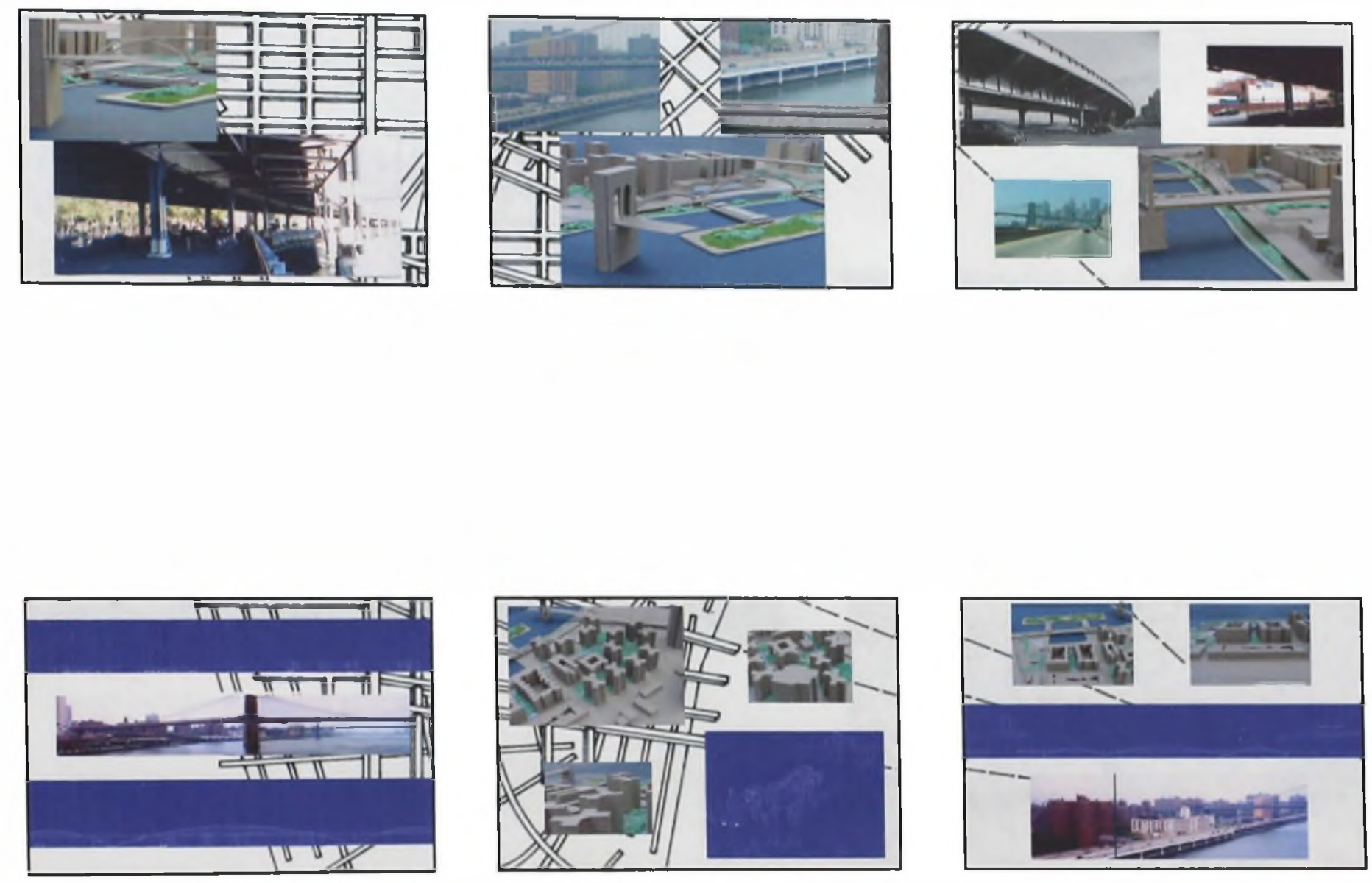

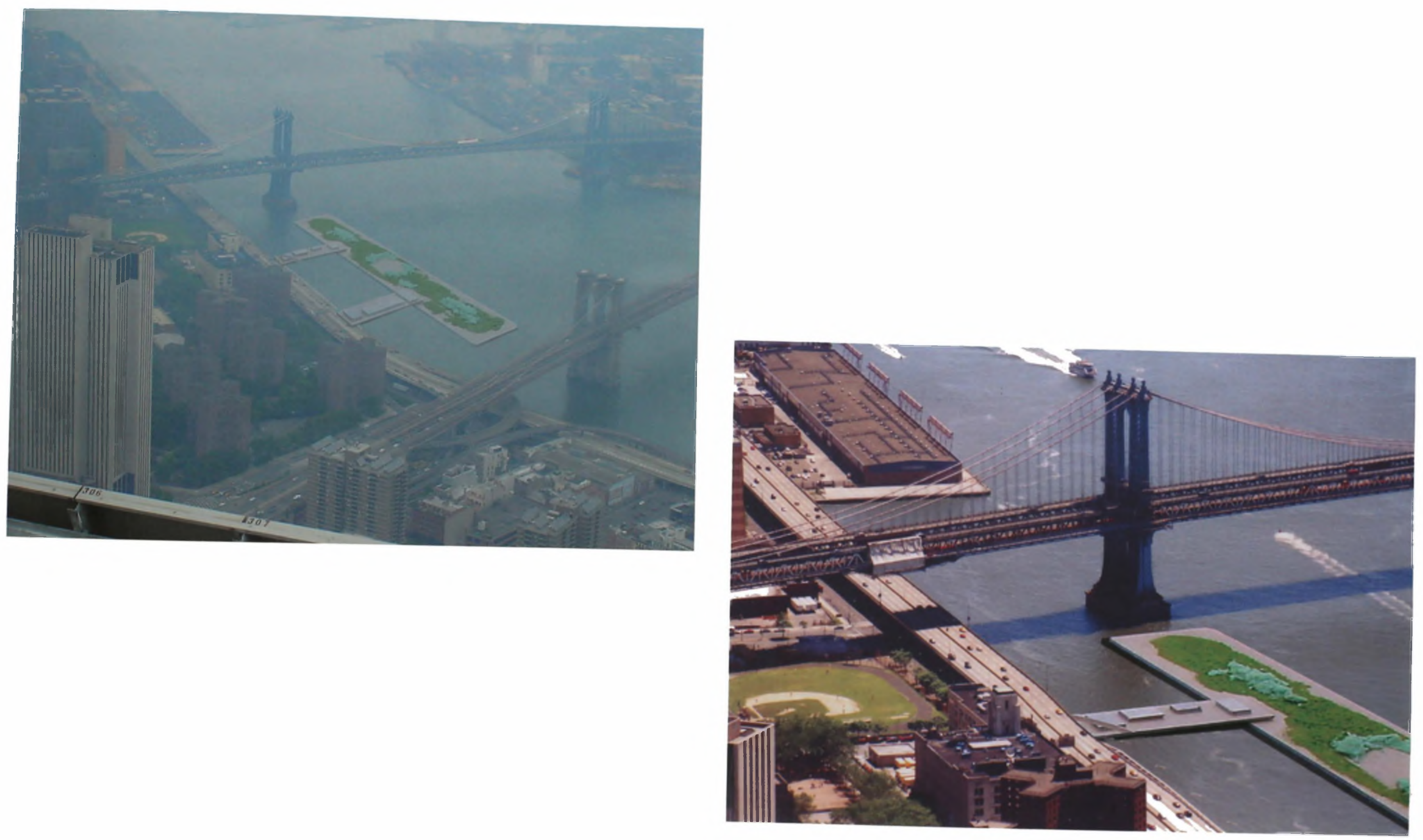

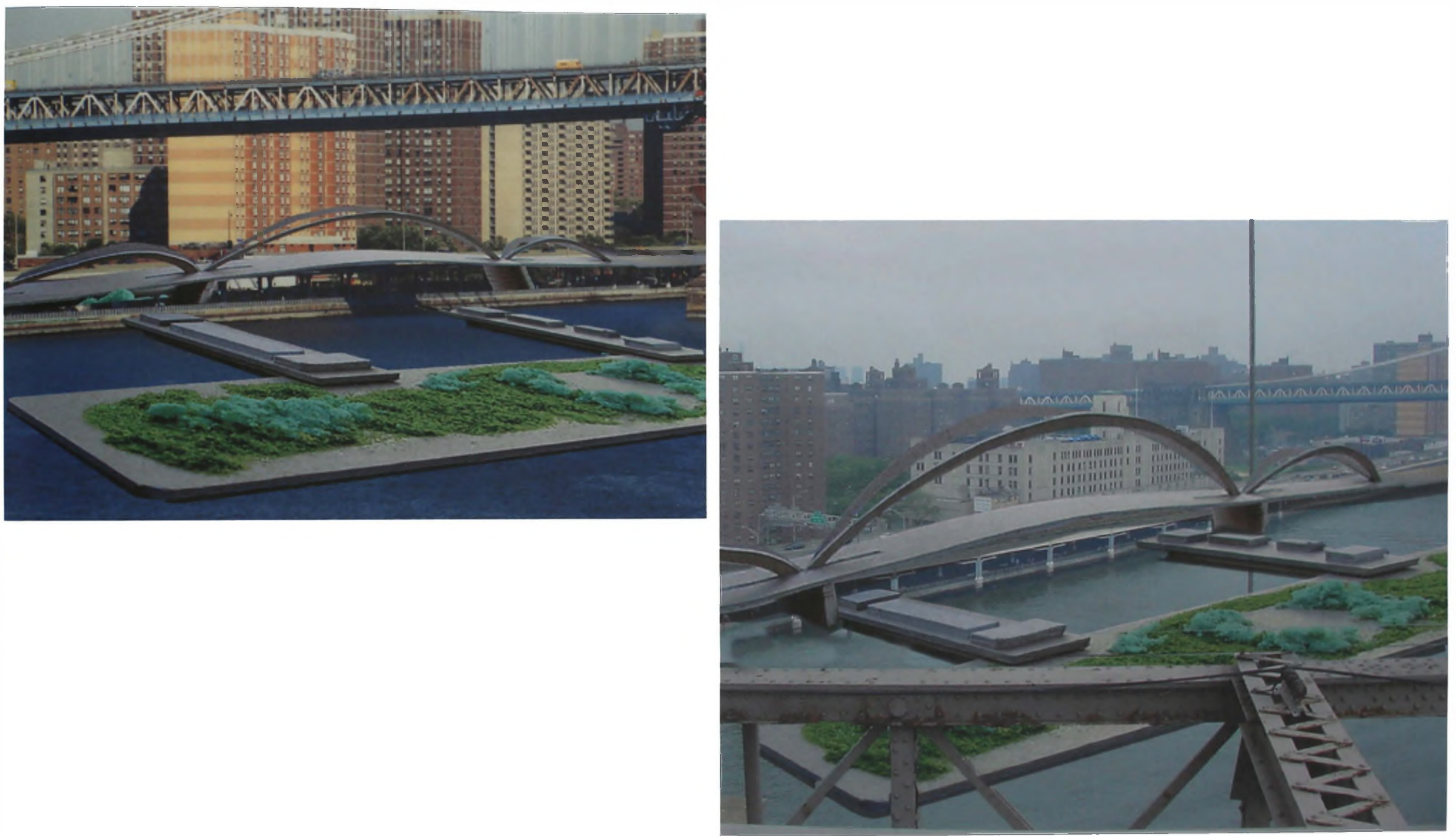


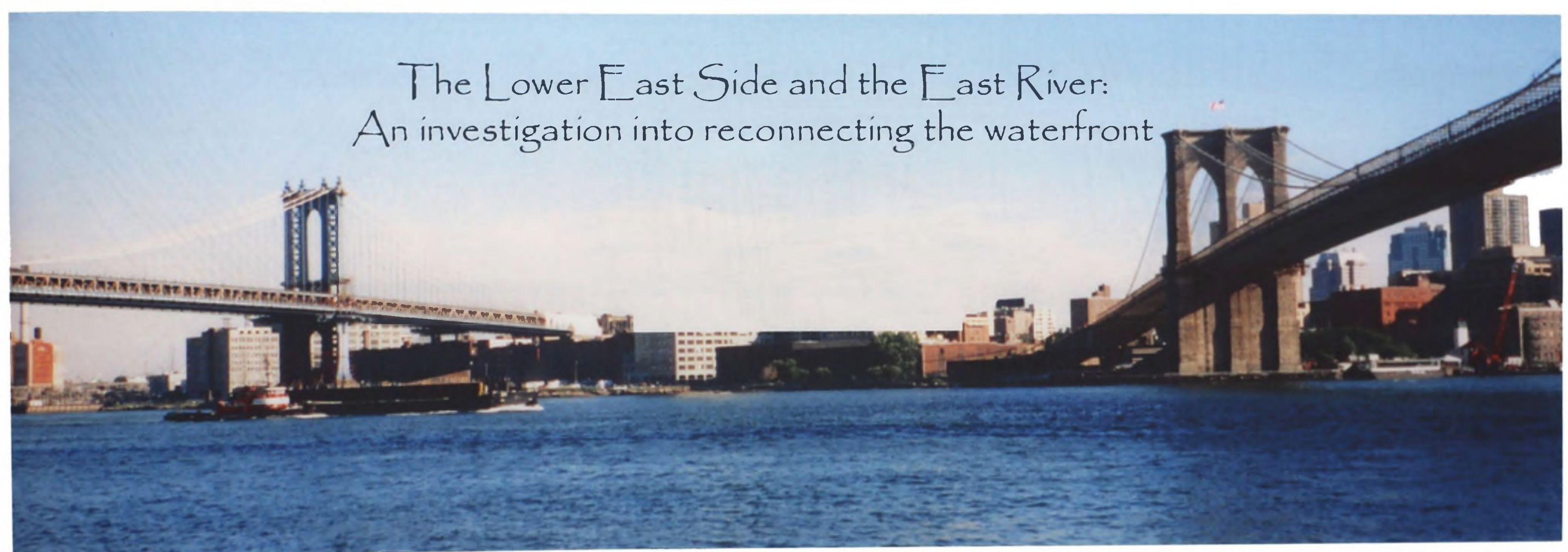




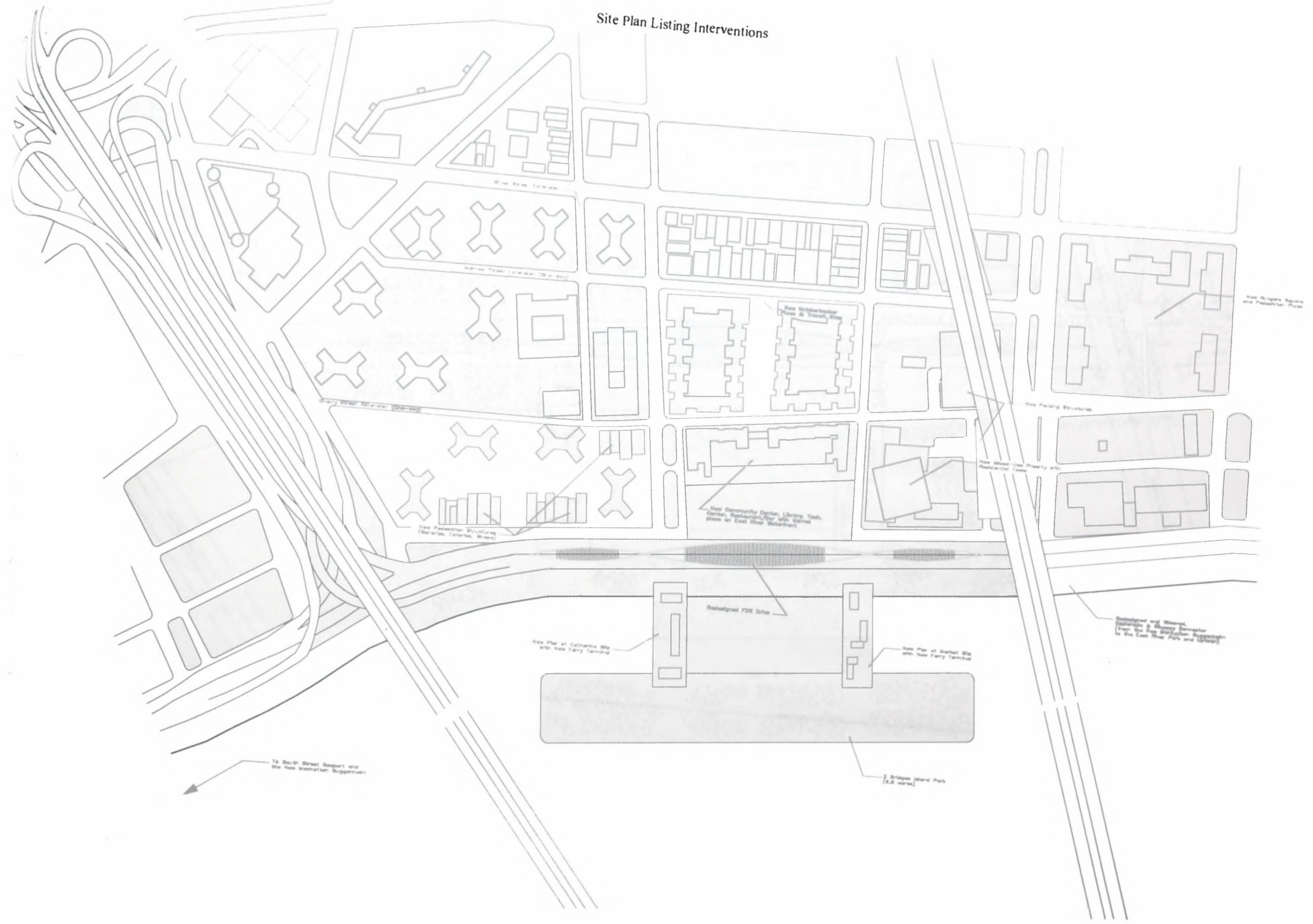


Site Plan, Elevations, and Sections

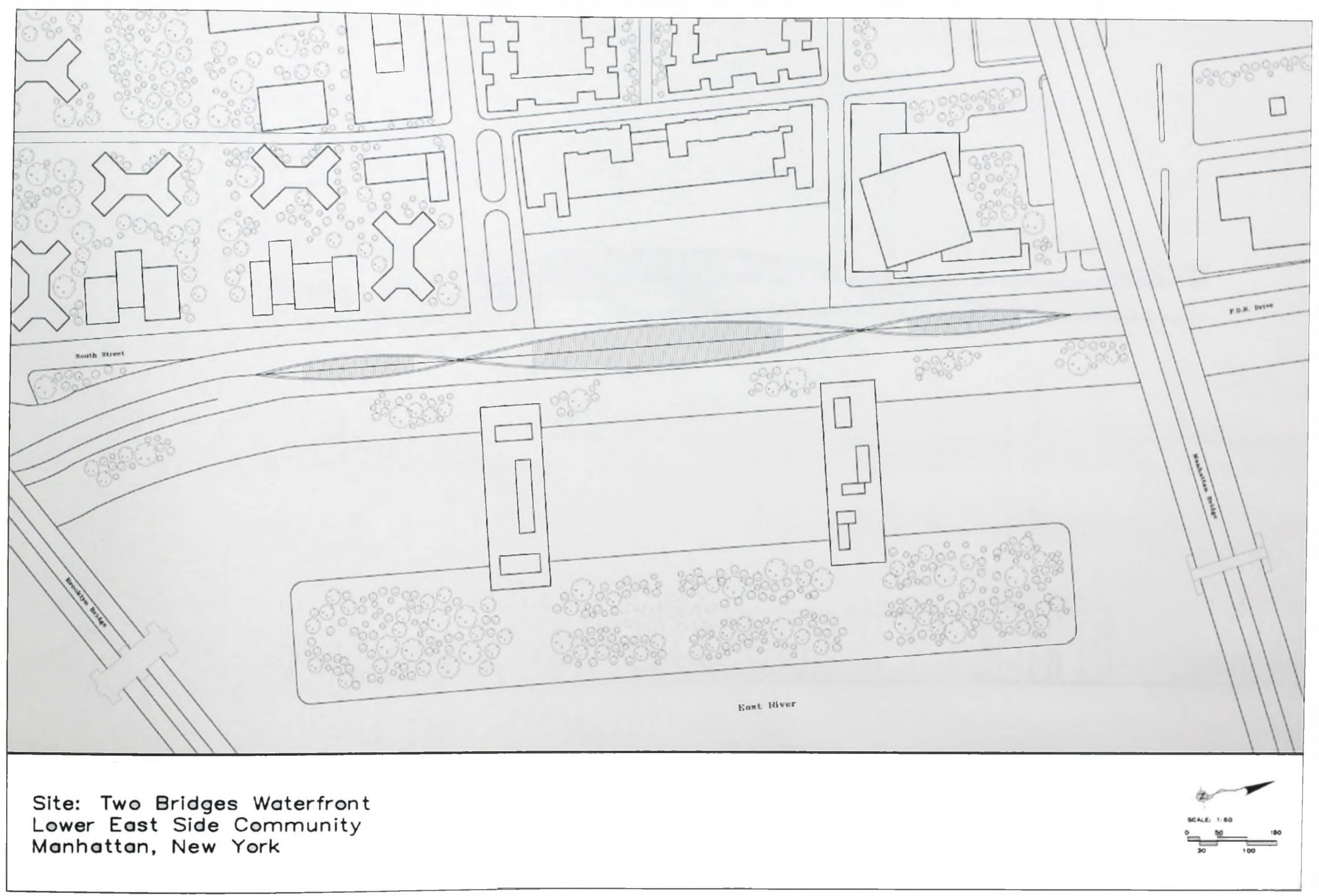



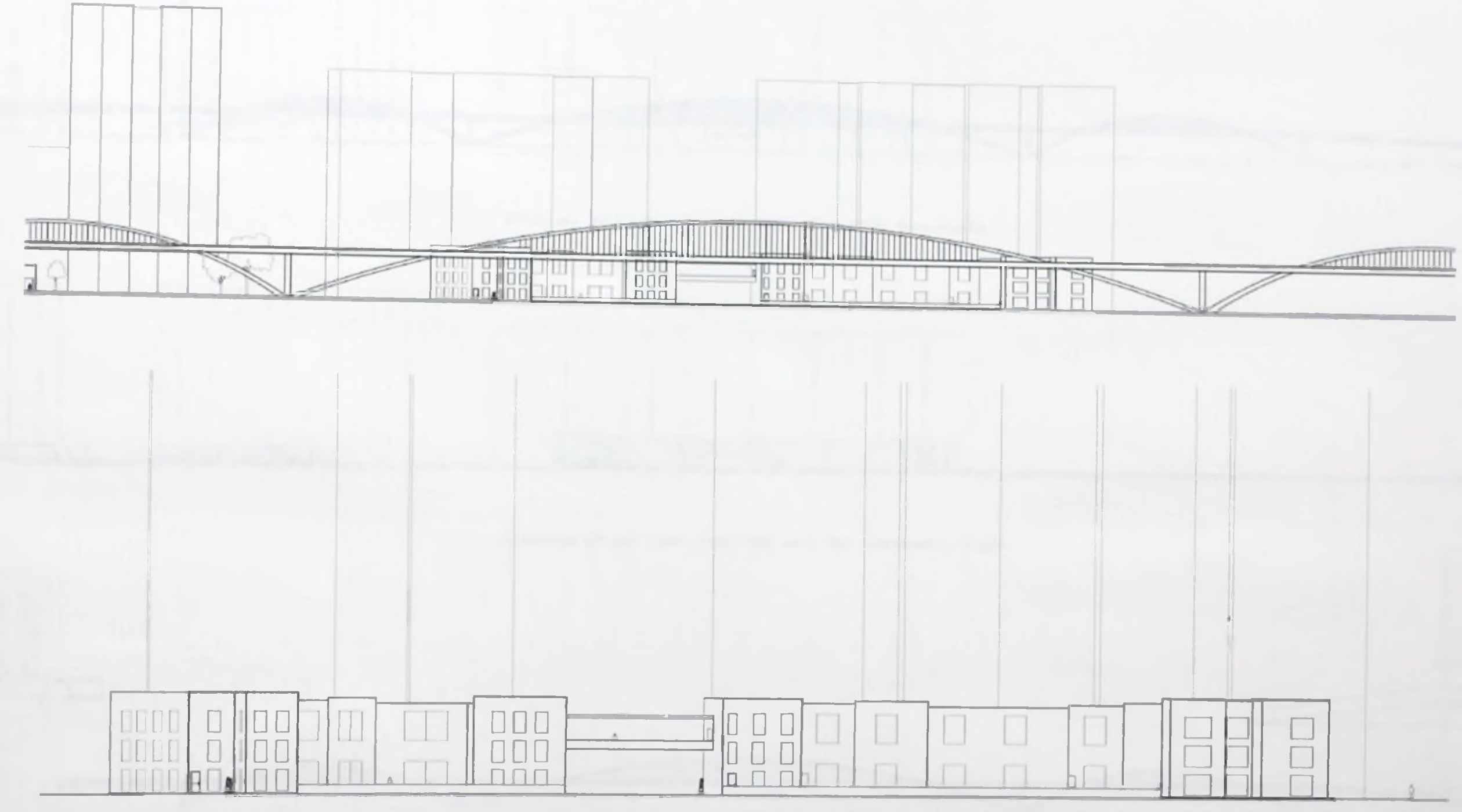


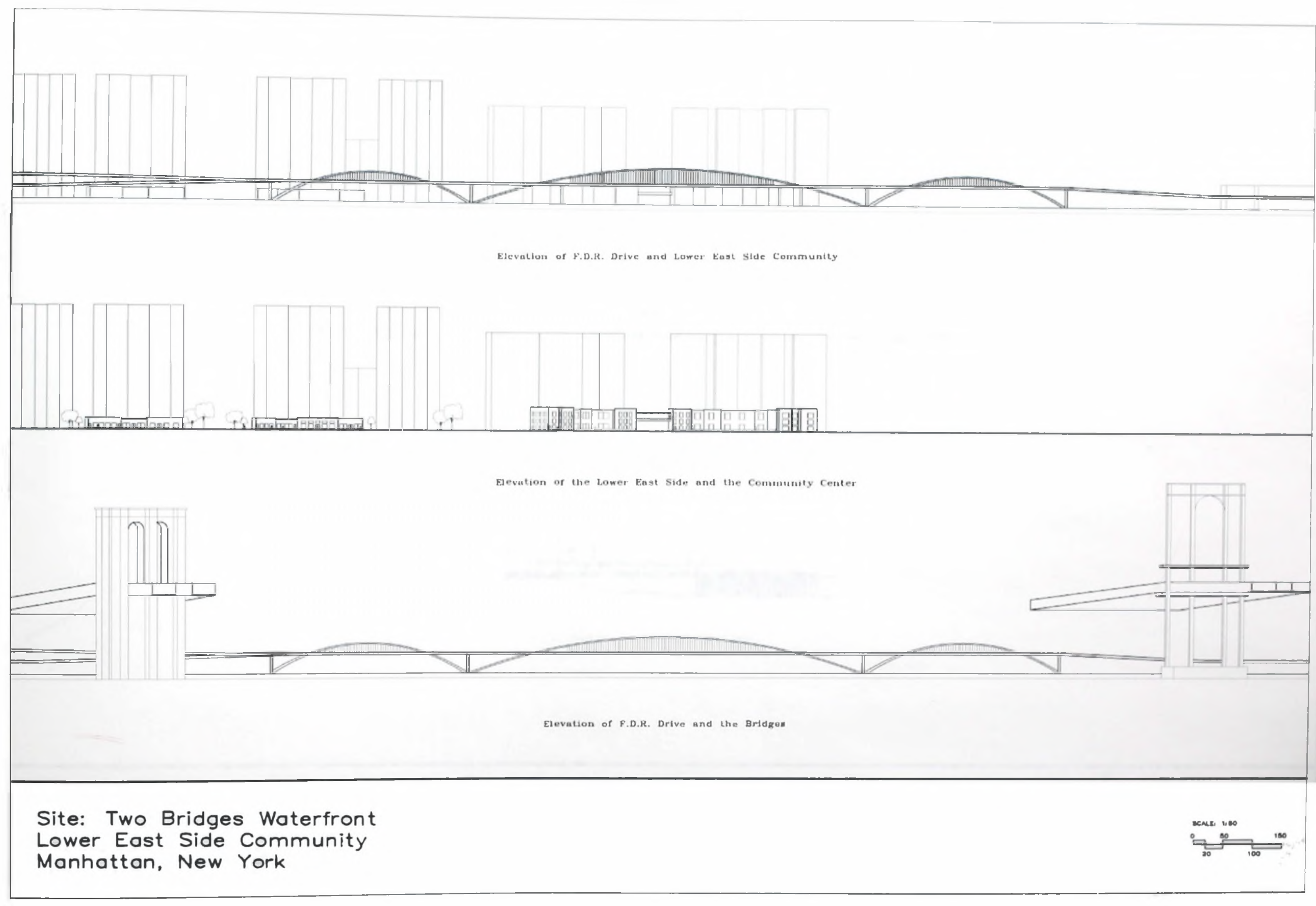




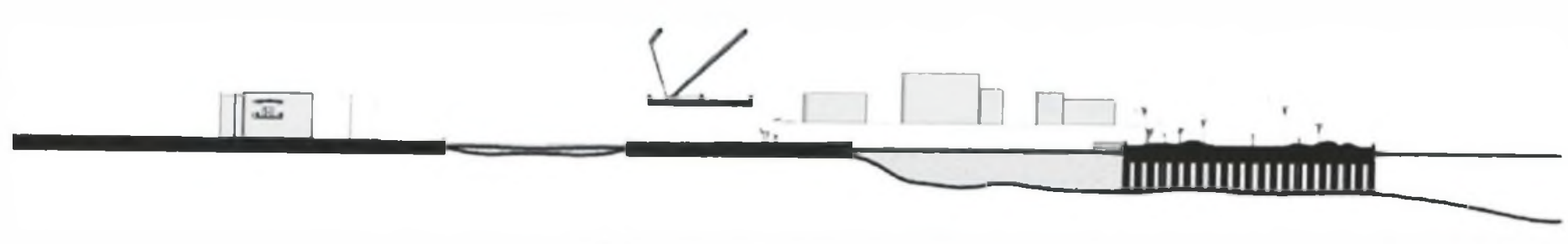

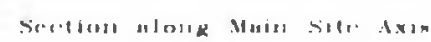

- P

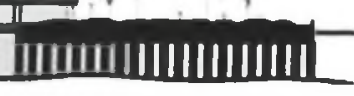

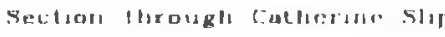

Site: Two Bridges Waterfront

Lower East Side Community

Manhattan, New York

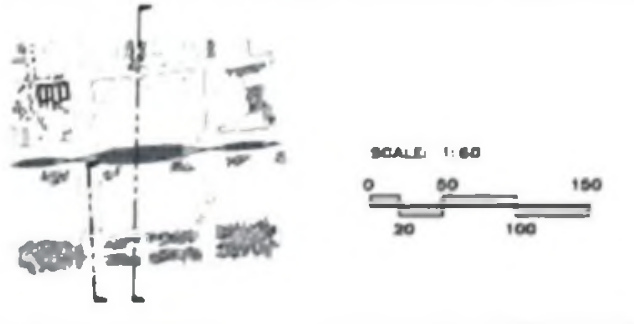


'Ann Breen and Dick Righy. The New Wateriront: A Worldwide Urban Success Story. (New York: McGraw-Hill. 1996). 11

${ }^{2}$ Ric Burns and James Sanders. New York: An Illustrated History. (New York: Allied A.Knopf \& Borzoi Books, 1999), xiii.

3 Ibid. 19.

NOTE: Named in homor of the Duke of York (1) whom the colony was promised as a hirthday' gift.

tibid, 24.

5 Ibid, 28.

NOTE: The American component of the French and Indian War, between the English and the French was known as the Seven Years War (1754-63) which ended with the Treaty of Paris (1763).

${ }^{6}$ Tory - name for the American colonists who either sympathized with or assisted the British during the Revolutionary War; a person opposed to the separation of the colonies from Great Britain

${ }^{7}$ Selma Berrol, The Empire City: New York and lts People, 1624-1996. (Westport: Praeger Publishers, 1997), 23.

${ }^{8}$ Burns and Sanders, 46

${ }^{9}$ Ibid.

${ }^{10}$ Ibid.

"Workers of the Writers Program of the Work Projects Administration for the City of New York, A Maritime History of New York. (New York: llaskell llouse Publishers, Ltd. 1973), 155.

12 Ibid. 181.

NOTE: This citation also includes the preceding sentence.

${ }^{13}$ Ann L. Buttenwieser, Manhattan Water-Bound. (New York: New York Univ. Press. 1987), 49.

${ }^{14}$ Berrol, 55.

NOTE: This cilation also includes the preceding two sentences.

${ }^{15}$ Ibid.

${ }^{16}$ Buttenwieser, 69-71. 
${ }^{17}$ Ibid. 98.

${ }^{18}$ Ibid.

NOTE: Included quotes are from Butfenwieser's source: The Report of the Honorable Cieorge' B.

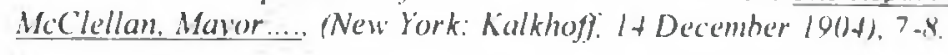

${ }^{19}$ Ibid. $99-100$

NOTE: This citation applies to the final three sentences.

${ }^{20}$ Workers of the Writers Program of the Work Projects Administration for the City of New York, 242.

${ }^{21}$ lbid. 247-248.

${ }^{22}$ Kevin Bone, The New York Waterfront: Evolution and Building Culture of the Port and Harbor. (New York: Monacelli Press, 1997), 77.

${ }^{23}$ Ibid. 79.

NOTE: Includes information found in the previous three sentences as well.

${ }^{24}$ lbid. 80.

${ }^{25}$ Ibid.

NOTE: This ciration includes information found throughou the preceding paragraph, not only the quotation.

${ }^{26}$ Workers of the Writers Program of the Work Projects Administration for the City of New York, 263.

NOTE: This ciration to include the caption above Figure 17 (see also the List of Figures).

${ }^{27}$ Burns and Sanders, 471.

${ }^{28}$ Ibid.

${ }^{29}$ Bone, 135.

NOTE: This ciration includes information found throughour the paragraph, including the quotations.

${ }^{30}$ Containerization - term used to describe the standardization of the cargo shipping industry in the late $20^{\text {th }}$ Century. By setting the sizes of railroad boxcars to a specific Standard, trucks and ships could be built in likewise fashion to facilitate the loading/unloading/transporting of goods. This also required new facilities for rail and shipyards as well as the equipment to handle the loading and unloading.

${ }^{31}$ Norman J. Brouwer, "Port of New York," The Encyclopedia of New York, ed. Kenneth T. Jackson, (New Haven: Yale University Press, 1995), 929.

${ }^{32}$ Breen and Rigby, 15-17. 
${ }^{33}$ NOTE: The new Fulton Market Convention Center and Downtown Meeting Area by the Glazier Group is slated to open in Spring 2002.

${ }^{34}$ Brouwer. 926

${ }^{35}$ Bone, 237.

${ }^{36}$ Ibid.

${ }^{37}$ Ibid. 239.

${ }^{38}$ Breen and Rigby, 137.

NOTE: Includes the following sentence as well.

${ }^{39}$ Anthony Iannacci. Butler Rogers Baskett: Revitalizing the Waterfront. (Milan: I'Arca Ediziona, 1997), 9.

${ }^{40}$ Ibid, 10.

NOTE: Includes information found within the preceding paragraph. Due to the sile being placed on the Register of Historic Places, stringent guidelines had to be obeyed by the archilects.

${ }^{4 !}$ David L. A. Gordon, Battery Park Citv: Politics and Planning on the New York Waterfront. (Ontario: Gordon and Breach Publishers, 1997), 66.

${ }^{42}$ Bone, 205.

${ }^{43}$ Gordon, 73 .

${ }^{44}$ Ibid. 78-79.

${ }^{45}$ Ibid. 83.

${ }^{46}$ Ibid, 49.

${ }^{47}$ Ibid. 111.

${ }^{48}$ Ibid.

${ }^{49}$ Ibid.

NOTE: This citation denotes that the cired information was developed from generalizations or deductions based on the information acquired from this source.

\section{${ }^{50}$ Bone, $257-258$}

NOTE: This citation also includes the preceding sentence.

${ }^{51}$ Breen and Rigby, 23. 
${ }^{52}$ Susan S. Fainstein. The City Builders: Property. Politics, \& Planning in London and New York, (Cambridge: Blackwell Publishers, 1994), 13.

${ }^{53}$ Ibid. ix $-x$

NOTE: This citation also includes the preceding sentence.

St Ibid. 43.

5. $\underline{\text { lbid. }} 194$.

${ }^{56}$ Ibid. 195.

${ }^{57}$ Janet Foster, Docklands: Cultures in Conflict, Worlds in Collision. (Philadclphia: UCI Press Unlimited. 1999). 27.

${ }^{58}$ Ibid. 39.

${ }^{59}$ Sue Brownill, Developing London's Docklands: Another (ireat Planning Disaster?. (London: Paul Chapman Publishing L.td, 1990), 54.

${ }^{60}$ Ibid. 63.

${ }^{61}$ Breen and Rigby, 20.

NOTE: This citation also includes the preceding sentence. Of the 5 billion, 2.2 billion is said to have come direcily from Olympia \& York.

62“"News," Architecture. Aug 2001, 31.

NOTE: Article states that the Wellness Trust, a medical charity, is in negotiations with the British Government to purchase the Dome.

${ }^{63}$ Brownill, 108 .

${ }^{64}$ Alan Plattus, Colin Rowe, and Fred Koetter, Koetter Kim \& Associates: Place/Time. (New York: Rizzoli International Publications, Inc., 1997), 72.

${ }^{65}$ Ibid. 73.

${ }^{66}$ Ibid. 76.

${ }^{67}$ Brownill, 109

${ }^{68}$ Harvey W. Zorbaugh, The Gold Coast and the Slum. (Chicago: The University of Chicago Press, 1929), 1.

${ }^{69}$ Dick Simpson, ed., Chicago's Future: An Agenda for Change (Chicago: The Swallow Press Inc., 1980), 474. 
${ }^{70}$ Harold M. Mayer and Richard C. Wade, Chicago: Growth of a Metropolis, (Chicago: The University of Chicago Press, 1969), 297.

Lois Wille, born in Chicago and allended Medill School of Journalism at Northwestern University. She reported urban issues for the Chicago Daily News. where her series of articles of health care for indigent women won the Pulizer Prize for public service in 1963. She is the author of Forever Open. Clear and Free: The Siruggle for Chicago's Laketront.

${ }^{71}$ Simpson, 470 .

${ }^{72}$ Breen and Rigby, 84

${ }^{73}$ Ibid.

${ }^{74}$ Ibid. 85.

NOTE: Layout for pier derived from this source as well as the Brochure Produced for the Navy Pier by the Chicago Convention and Tourism Bureau, as well as the web site for the Navy Pier.

${ }^{75}$ Janet L. Abu-Loghod, New York. Chicago. Los Angeles: America's Global Cities, (Minneapolis: University of Minnesota Press, 1999), 321.

${ }^{76}$ Burns and Sanders, 246.

${ }^{77}$ Buttenwieser, 165.

${ }^{78}$ Ibid. 170

${ }^{79}$ Ibid. 172-173.

${ }^{80}$ Burns and Sanders, 429 .

${ }^{81}$ Robert Moses built 7 bridges during his 44 years in power and it is his Triborough Bridge Project that he is most famous. Moses is also credited with creating the parkway and establishing the interstate guidelines that the federal government would adopt years later.

-From a reprinted interview with Robert A. Caro. Source: Burns and Sanders, 458-465.

${ }^{82}$ Buttenwieser, 180.

${ }^{83}$ Ibid. 181.

${ }^{84}$ Ibid. 184

${ }^{85} \underline{\text { lbid, }}$ 184-185.

${ }^{86}$ Ibid. 188.

${ }^{87}$ Rebecca Read Shanor, The City That Never Was. (New York: Viking, 1988), xv.

${ }^{88}$ Bone, 227 
${ }^{89}$ Ibid. 229.

VOTE: Includes previous listing of those involved

${ }^{90}$ Herbert Muschamp, "A Bridge Between a City and Its Self-Image," The New York Times. 13 June 1999, AR37.

${ }^{91}$ John E. Czarnecki, "Pei Cobb Freed and SOM to plan NYC East River site," Architectural Record, July 2001,28

NOTE: Includes all information stated ahour this project.

${ }^{92}$ Anthony Mariani. "New Guggenheim Approved for Big Apple," Architecture. Junuary 2001.29.

${ }^{93}$ Thomas Kerns, Director, "Project for a New Guggenheim Museum in New York (ity," a) Guggenheim: The Guide to the Gungenhein Museums. Summer 2000, 8-9.

${ }^{94}$ Soren Larson, "Gehry`s Next Guggenheim," Architectural Record, May 2000, 41

${ }^{95}$ Excerpts taken from program information available and exhihited along with the 'New (juggenheim for Manhattan' Project, Summer 2001.

${ }^{96}$ Susan Stefans and Clifford Pearson, "Asymptote envisions a sleek and dynamic Museum of Technology Culture," Architectural Record. December 1999, 92-95.

${ }^{97}$ NOTE: Personal observation.

${ }^{98}$ Breen and Rigby, 19-20

${ }^{99}$ NOTE: Altempts to acquire information as to the amount of pipes, their direction, or their depth have resulted in the same answers from various city departments-"We are not sure"

${ }^{100}$ Breen and Rigby, 153.

${ }^{101}$ Sergio Polano, Santiago Calatrava: Complete Works. (Milan: Electa, 1996). Structural information and images of Santiago Calatrava's bridges were oblained from a variety of sources abou his work. The (wo primary sources were his website (www.calalrava.com) and the above sources abount
noted book.

${ }^{102}$ NOTE: Joel Ferree is a tour guide with the Lower East Side Tenement Museum. The Museum is located on Orchard Street in the Lower East Side. Joel is well versed on not only the history of the area but also the current conditions, needs, and desires of the community and its people.

${ }^{103}$ NOTE: This past year, ferry transit around Manhattan was steadily increasing. However, the events of September 11, 2001 have led to an overwhelming number of ferry passengers. New routes and stops are being discussed and new ferry companies are seeking the proper licenses to operate in New York. Source of this information came from a variety of news sources, including but nor limited to, CNN NYI, MSNBC, and The Evening News with Dan Rather. 
${ }^{104}$ Iannacci.

NOTE: All information contained within this Appendix $A$, including the figures, was provided by this source.

${ }^{105}$ NOTE: Information on Battery Park City was obrained from a variety of sources, including personal visits to the area. It is important to note, however, that this information can also be fornd in David Gordon's Battery Park Cin. 
Janet L. Abu-Loghod, New York. Chicago, Los Angeles: America's Global Cities. (Minneapolis: University of Minnesota Press, 1999).

Vernon Howe Bailey, Magical City: Intimate Sketches of New York. (New York: Charles Scribner`s Sons, 1935)

Richard Baiter, Lower Manhattan Waterfront. (New York: Office of the Mayor of New York City, Abraham D. Beame, June 1975).

Selma Berrol, The Empire City: New York and Its People. 1624-1996. (Westport: Praeger Publishers, 1997).

Brian J. L. Berry, ed., Chicago: Transformations of an Urban System. (Cambridge: Ballinger Publishing Company, 1976).

Kevin Bone, The New York Waterfront: Evolution and Building Culture of the Port and Harbor. (New York: Monacelli Press, 1997).

Ann Breen and Dick Rigby, The New Waterfront: A Worldwide Urban Success Story. (New York: McGraw-Hill, 1996).

Norman J. Brouwer, "Port of New York," The Encyclopedia of New York. ed. Kenneth T. Jackson, (New Haven: Yale University Press, 1995).

Norman J. Brouwer, "South Street Seaport," The Encyclopedia of New York. ed. Kenneth T. Jackson, (New Haven: Yale University Press, 1995).

Sue Brownill, Developing London's Docklands: Another Great Planning Disaster? (London: Paul Chapman Publishing Ltd, 1990).

Ric Burns and James Sanders, New York: An Illustrated History. (New York: Alfred A. Knopf \& Borzoi Books, 1999). 1987).

Ann L. Buttenwieser, Manhattan Water-Bound. (New York: New York Univ. Press,

"Buzz," News section of Architecture. August 2001.

Carl W. Condit, Chicago 1910-1929: Building. Planning, and Urban Technology, (Chicago: The University of Chicago Press, 1973).

John E. Czarnecki, "Pei Cobb Freed and SOM to plan NYC East River site," Architectural Record. July 2001.

Barbaralee Diamonstein, The Landmarks of New York III, (New York: Harry N. Abrams, Inc., 1998). 
Gt Ellin, "Battery Park City," The Encyclopedia of New York, ed. Kenneth 'T, Iack (New Haven: Yale University Press, 1995).

Susan S. Fainstein. The City Builders: Property. Politics, \& Planning in London and New York. (Cambridge: Blackwell Publishers, 1994).

Mildred Friedman, "Frank Gehry Architect," G Guggenheim: The Guide to the Guggenheim Museums. Summer 2001.

Janet Foster, Docklands: Cultures in Conflict, Worlds in Collision. (Philadelphia: UCl. Press Unlimited, 1999).

Mario Gandelsonas, X-Urbanism: Architecture and the American City. (New York: Princeton Architectural Press, 1999).

James Gilbert. Perfect Cities: Chicago's Utopias of 1893. (Chicago: The University of (hicago Press, 1991)

David L. A. Gordon. Battery Park City: Politics and Planning on the New York Waterfiont. (Ontario: Gordon and Breach Publishers, 1997).

Cynthia Grant and Simon Borthwick. Photo Docklands. (Leeds: L.DDC. 1997).

Elizabeth Hawes, "What's New York the Capital of Now? The Waterfront 2004," New York Times, 29 November 1994

David Heald, "The Guggenheim Woos Downtown," The Battery Park City Broadsheet. vol. 4 , no. 10 , June 2000

Steven Holl, "The Alphabetical City," Pamphlet Architecture \#5. (New York: Pamphlet Architecture, 1980).

Steven Holl, Parallax, (New York: Princeton Architectural Press, 2000). 1994).

Eric Homberger, The Historical Atlas of New York City. (New York: Henry Holt \& C'o..

Anthony lannacci, Butler Rogers Baskett: Revitalizing the Waterfront. (Milan: I'Arca Ediziona. 1997).

Vernon Jensen. Strife on the Waterfront, (New York: Cornell Univ. Press, 1974).

Thomas Kerns, Director, "Project for a New Guggenheim Museum in New York City," a) Guggenheim: The Guide to the Guggenheim Museums, Summer 2000.

Thomas Kerns, Director, "Project for a New Guggenheim Museum in New York City," a Guggenheim: The Guide to the Guggenheim Museums. Summer 2001.

Soren Larson, "Gehry’s Next Guggenheim," Architectural Record. May 2000 
Lower Manhattan Waterfront: The Special Battery Park Citv Iistrict. The Special Manhattan L anding Development District. The Special South Street Scaport District. prepared for Abraham D. Beame, Mayor, City of New York and Il. Claude Shostal. Director. Onfice of Lower Manhattan Development. June 1975.

Patrick Malone, ed., (ity. capital, and water, (New York: Routledge, 1996). 2001.

Anthony Mariani, "New Guggenheim Approved for Big Apple," Architecture. January

Harold M. Mayer and Richard C. Wade, Chicago: Growth of a Metropolis. (Chicago: The University of Chicago Press, 1969).

Joyce Mendelsohn. The Lower East Side: Remembered \& Revisited. (New York: The Lower East Press, 2001).

Metropolitan Waterfront Alliance, "Campaign for the Waterfront." Waterwire digest. Summer 2001.

Metropolitan Waterfront Alliance, "Metro Trails," Waterwire digest, Summer 2001.

Metropolitan Waterfront Alliance, "Working Waterfronts: Redefining 'Build to Suit'," Waterwire digest. Summer 2001

Herbert Muschamp, "A Bridge Between a City and Its Self-Image," The New York Times, 13 June 1999.

Herbert Muschamp, "Instant Inspiration: Just Add Water," The New York Times, 6 April 2001.

Alan Plattus, Colin Rowe, and Fred Koetter, Koetter Kim \& Associates: Place/Time. (New York: Rizzoli International Publications, Inc., 1997).

Sergio Polano, Santiago Calatrava: Complete Works. (Milan: Electa, 1996).

Nicolas Quintana, Social History of the Built Form / Real Urbanism Coursebook. (Miami: FIU Copy Center, 1999).

Colin Rowe and Fred Koetter, Collage City. (Cambridge: The MIT Press, 1978).

Moshe Safdie, The City After the Automobile: An Architect's Vision. ( Boulder: West view Press, 1998).

Rebecca Read Shanor, The City That Never Was, (New York: Viking, 1988)

Dick Simpson, ed., Chicago's Future: An Agenda for Change (Chicago: The Swallow Press Inc., 1980).

Susanna Sirefman, "Collaborative Process Creates the Highly Praised Brooklyn Bridge Park," Architectural Record. June 2000 
Susan Stefans and Clifford Pearson. "Asymptote envisions a sleck and dynamic Museum of "Technology Culture." Architectural Record. December 1999.

John Tauranac. New York From The Air. (New York: Ilarry N. Abrams, Ine., 1998).

W'illiam R. Taylor. In Pursuit of Cotham: Culture and Commeree in New York. (New York: Oxford University Press, 1992).

Raymond Vernon. Metropolis 1985. (Cambridge: Ilarsard (Iniv. Press. 1960).

Elyse Umlauf-Garneau, "I Irhan Bright," Shopping Center World. July 200)1.

Santi Visalli, Chicago. (New York: Rizzoli International. 1987).

Karen Votava. ed., East Coast Greenway: 2001 State of the Trail Report. (Wakeficld: East (oast Greenway Alliance, Jan. 2001).

Lois Wille, At Home in the Loop: How Clout and Community Built Chicago's Dearborn Park. (Carbodale: Southern Illinois University Press, 1997).

Brett Williams. Upscaling Downtown. (New York: Corncll Univ. Press, 1988).

Workers of the Writers Program of the Work Projects Administration for the City of New York. A Maritime History of New York, (New York: Haskell House Publishers, I.td.. 1973).

Harvey W. Zorbaugh, The Gold Coast and the Slum. (Chicago: The University of Chicago Press. 1929).

The Lakefront Plan of Chicago, December 1972

1966

The Comprehensive Plan of Chicago, Dept. of Development \& Planning, December

\section{Primary Sources}

ANY Conference, Summer 2000, New York.

Frank O. Gehry presentation of the New Guggenheim for New York. Held June 2000 at the Solomon R. Guggenheim Museum in New York.

Lower East Side Tenement Museum \& Tour. The Museum is located at 90 Orchard Street. New York. New York. Includes an informal conversation/ interview with Joel Ferree Tenement Museum Guide. Visit took place on August 19, 2001. 
- Internet Sources

Santiago Calatrava

hltp //www calatrava com

Chicago Convention and Tourism Bureau http //Www chicago il org/NAWYPIER IITAII

The Official Site for The Navy Pier http.//www navypier com/

City of Chicago

hetp//www ci chi il us/Tourism/ht ml/Navylier html

New York City Roads

hup / www nycroads com/roads/fdr

New York City Dept. of Transportation

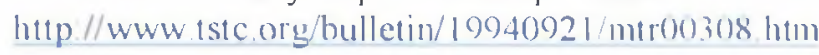

Jeff Salzman, New York Web Page, FDR Drive

http://www geocities com/SoHo/Canvas/2228/idr/phrdr htm

New York City, FDR Drive Exits

http//www nycroads com/exits/fdr

- Brochures

NYC Historic Orchard Street. Lower East Side, Produced by the Lower East Side Business Improvement District

Lower East Side Tenement Museum: June-August 2001. Produced regularly by the Lower East Side Tenement Museum,

Chelsea Piers Sports \& Entertainment. Chelsea Piers Management, Inc., 1998

South Street Seaport Directory, Affiliate of the Rouse Company, August 1999.

Architecture + Water, Van Alen Institute Projects in Public Architecture, Summer 2001 (accompanied exhibit) 
Butler Rogers Baskett set a highly innovative and creative precedent for the adaptive reuse of urban

infrastructures, which would not only have a positive affect on the community, but also on the environment ${ }^{104}$

\section{- \$25-30 million spent on infrastructure alone}

Electrical service

Plumbing

Water and Sewer lines

Sprinkler, Fire Alarms, and Emergency Lighting

- Since each venue required a unique environmental solution-temperatures ranging from 50 degrees for year-round ice-skating rinks to 80 degrees for the swimming pool to heated outdoor golf stalls - the design of the mechanical and electrical systems for the project presented a major challenge for the architects and project engineers, Cosentini Associates

- Four (4) 880-foot piers and the 90,000 square-foot Headhouse were renovated for both public and private facilities

- The project reclaimed unused and decaying waterfront structures

- Provided unrestricted public access to the waterfront in the form of a 20 foot-wide, 1.2 mile-long esplanade that runs along the perimeter of each of the piers.

- As the historic use of the piers for transatlantic shipping was no longer appropriate, the State Historic Preservation Office approved usage of the piers for a Sports and Entertainment Complex, yet required the rehabilitation of the historically significant fabric of the piers

- $\$ 100$ million project hosts 8,000 to 10,000 visitors per day, and employees 1,200 to 1,500

- The Headhouse includes:

-Chelsea Piers Field House - 80,000 sq. ft. of facilities for gymnastics, team sports, and league play

-Silver Screen Studios - 250,000 sq. ft space for sound stages, production offices,

storage, studio-support space, carpentry \& scenic painting shops, and dressing room

-Manhattan's largest fashion-photography facility $-30,000$ sq. $\mathrm{ft}$.
104

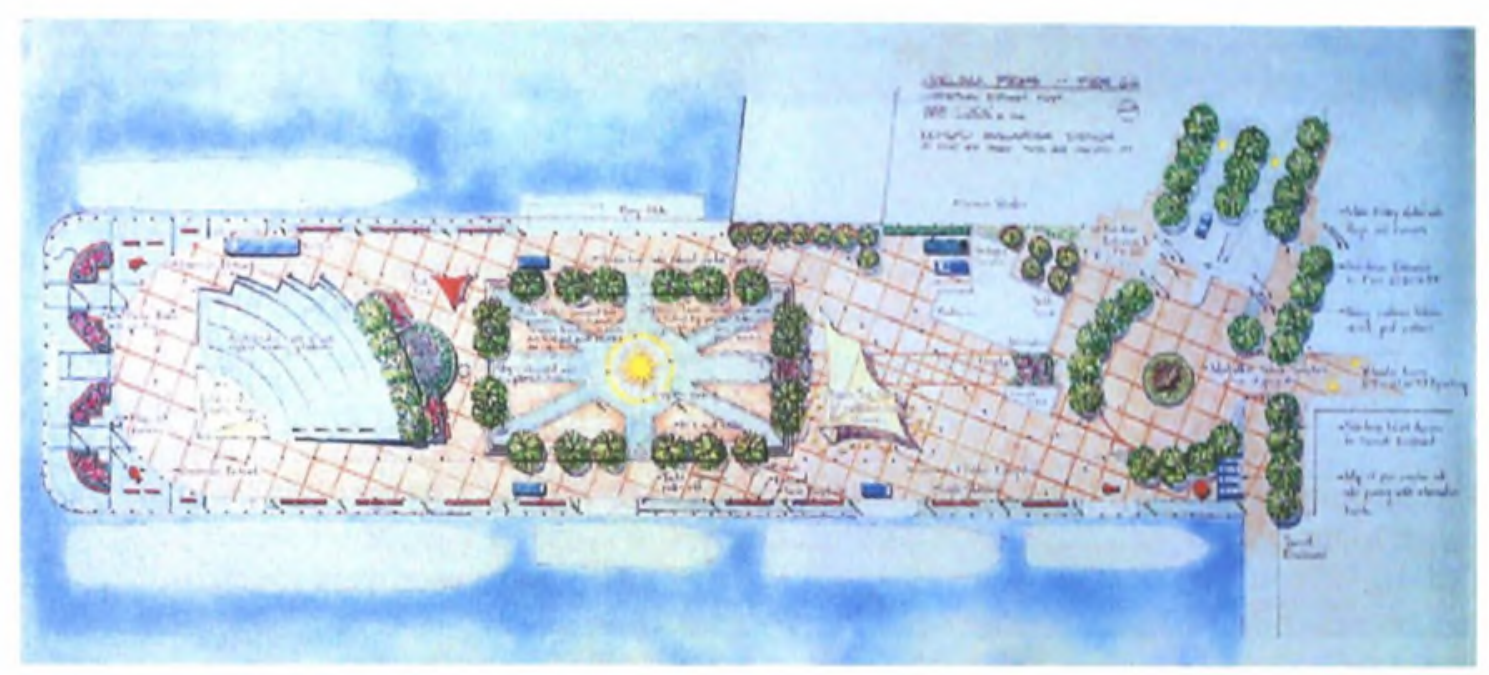

Sketch of the Outdoor Park and Skating Arca. Pier 62

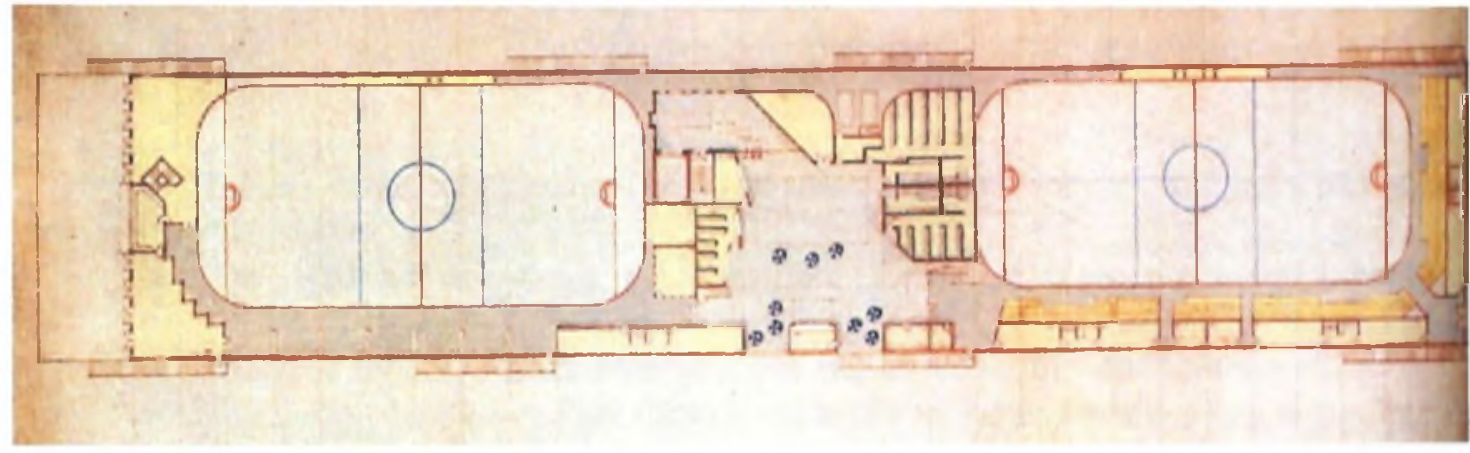

Plan of the dual rinks found on the Skyrink Pier

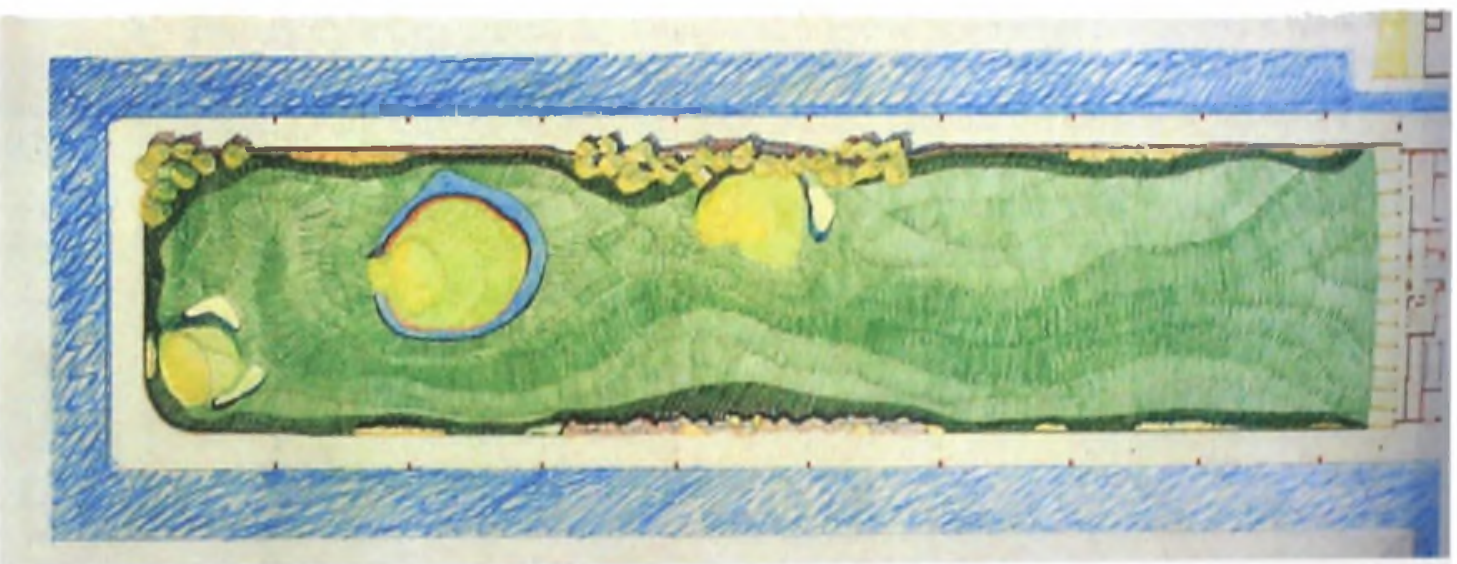

Sketch of the layout for the Golf Driving Range Pier 
1979 Masterplan for Battery Park City, by Alexander Cooper and Stanton Eckstut

- $42 \%$ of the land dedicated to housing

- $30 \%$ of the land dedicated to open spaces (including the Esplanade)

- $19 \%$ of the land dedicated to streets and avenues

- $9 \%$ of the land dedicated to commercial and office space

Future plans called for the construction of a luxury hotel, a Memorial to the Holocaust Museum of Jewish Heritage, a $5^{\text {th }}$ office tower, and more housing. As of this writing, all of these structures have been completed.

\section{The 8 Design Principles for the 1979 Masterplan:}

- Battery Park City should not be a self-contained new-town-in-town. but a part of lower Manhattan.

- The layout and orientation of Battery Park City should be an extension of lower Manhattan's system of streets and blocks.

- Battery Park City should offer an active and varied set of waterfront amenities.

- The design for Battery Park City should take a less idiosyncratic, more recognizable, and more understandable form.

- Circulation at Battery Park City should reemphasize the ground level.

- Battery Park City should reproduce and improve upon what is best about New York's neighborhoods.

- Battery Park City's commercial center should become the central focus of the project.

- Land use and development control should be sufficiently flexible to allow adjustment to future market requirements. 
Traffic Study and Analysis of the FDR Drive

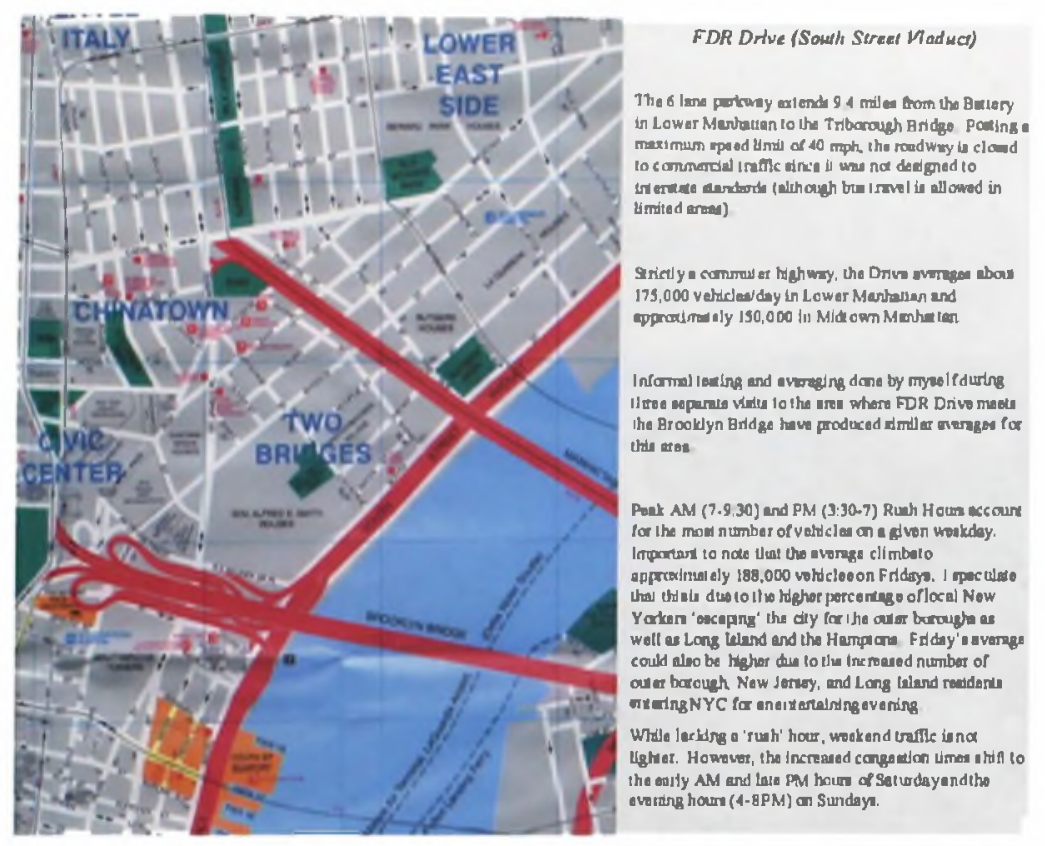

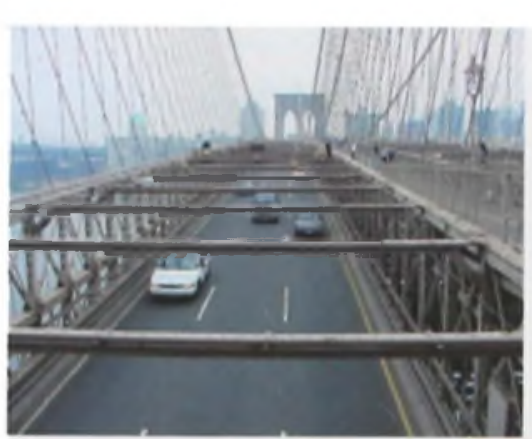

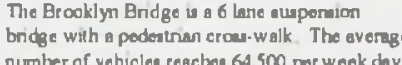

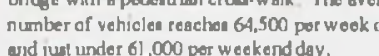
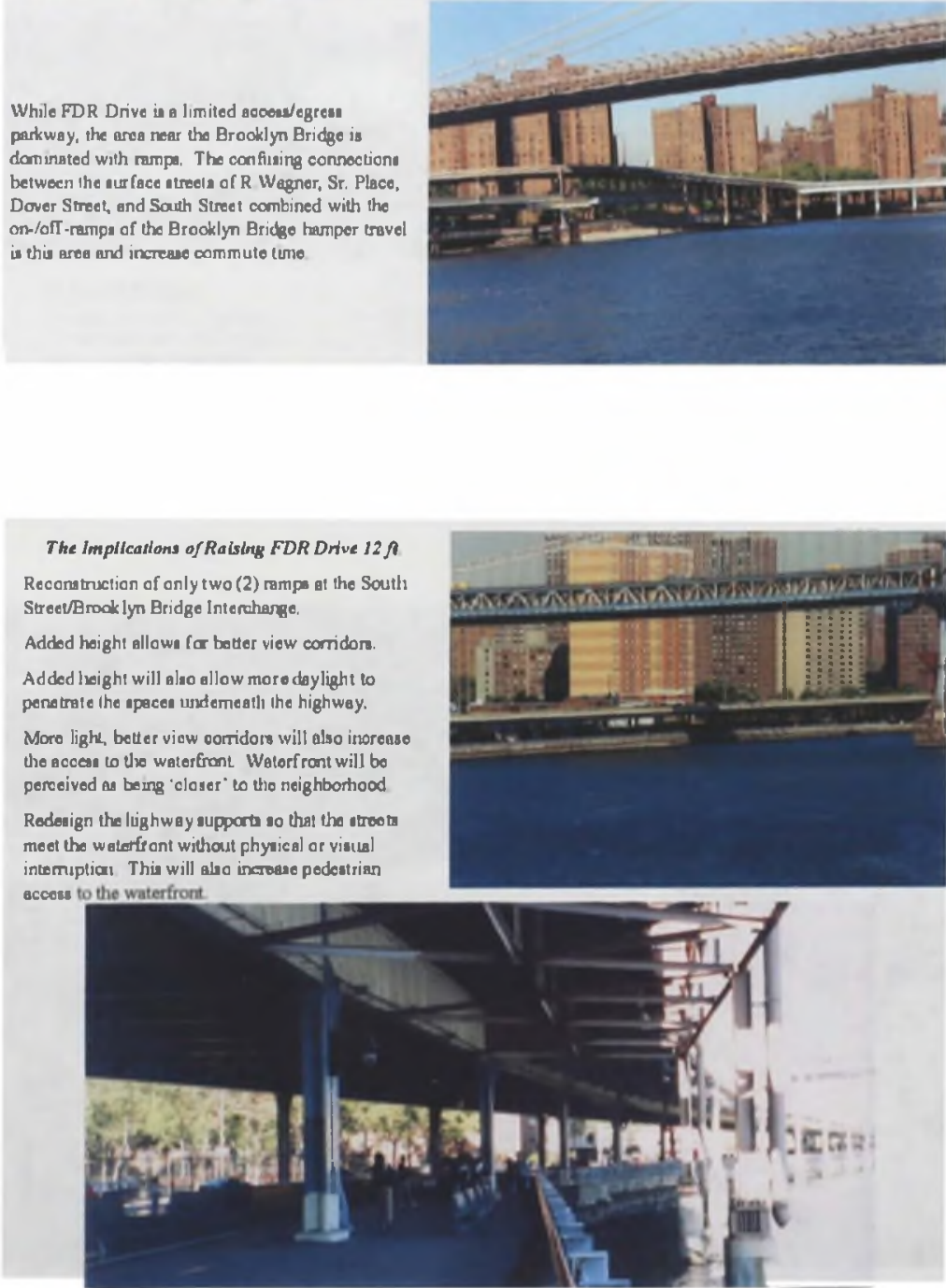
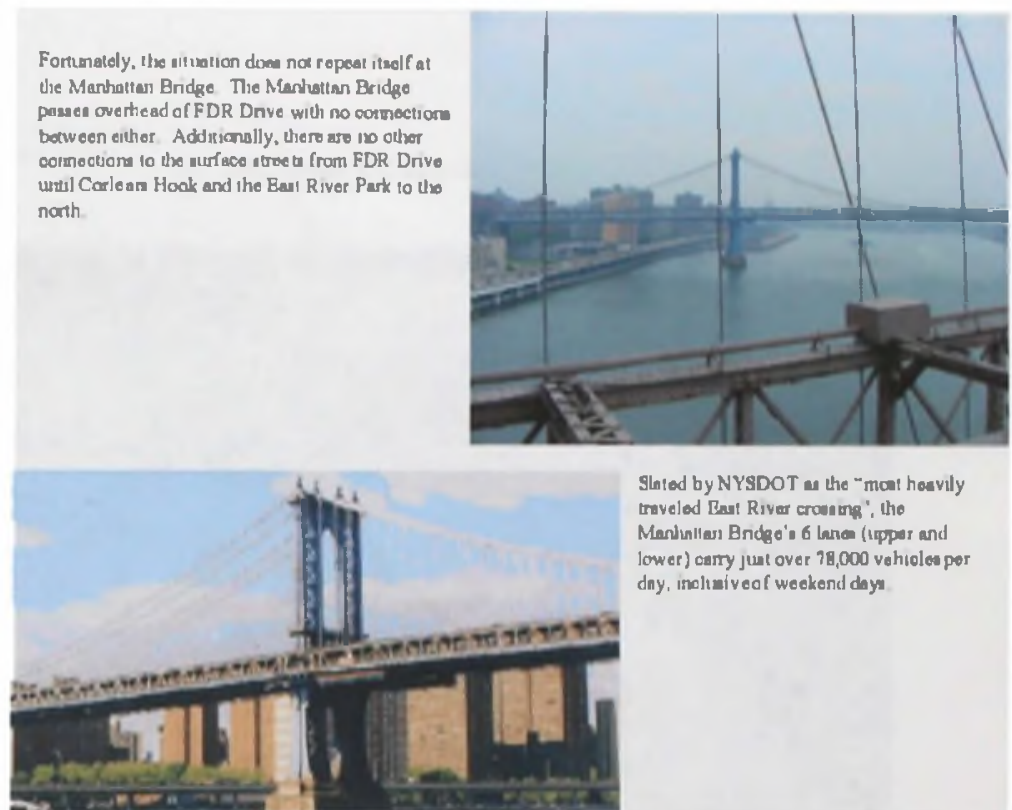

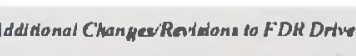

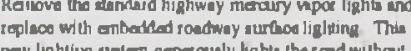

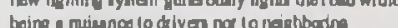

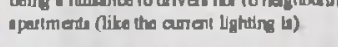

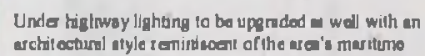

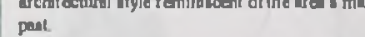

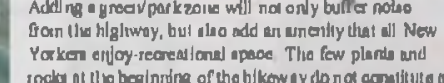

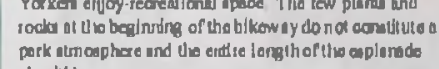

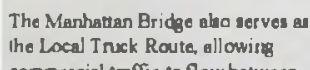

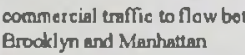

The Lower Ean Side frman the

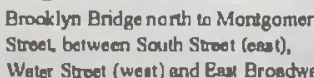

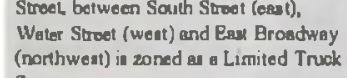

$(1)$

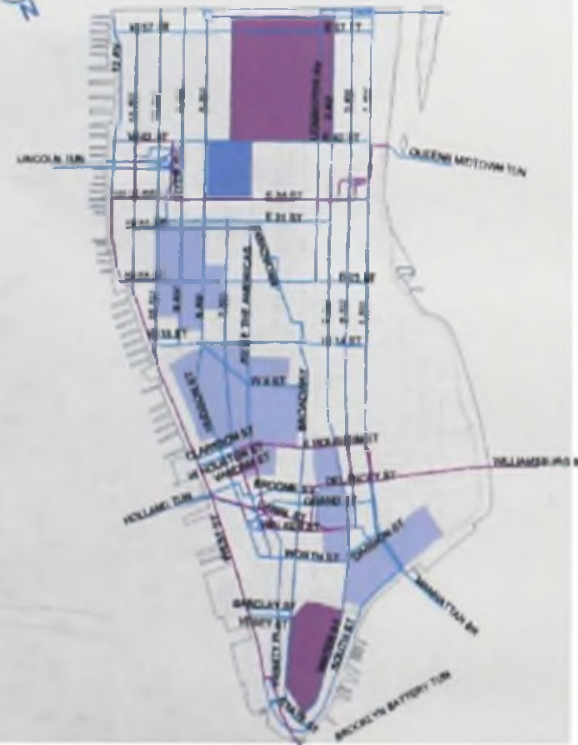

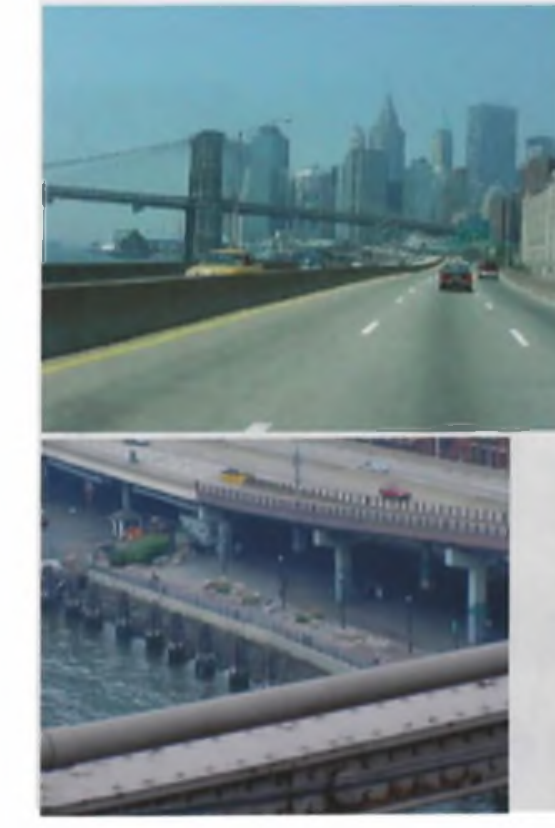

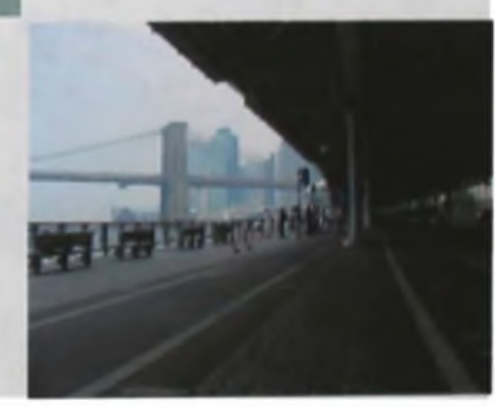




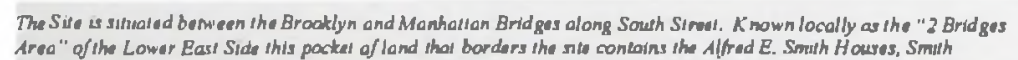

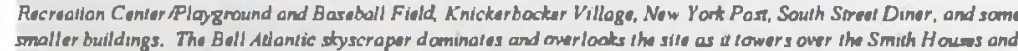

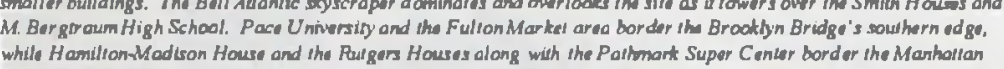
thidge's north side.
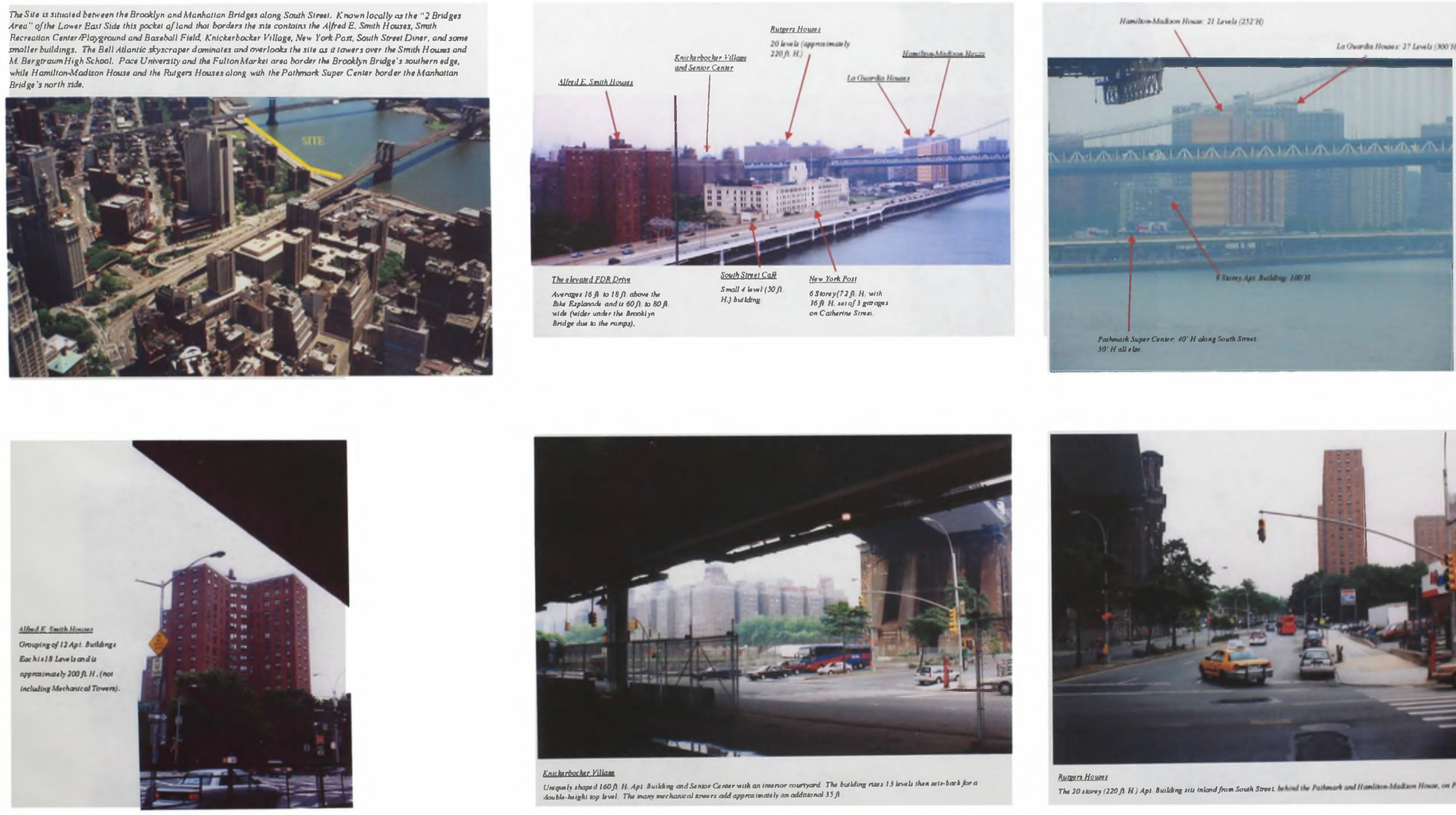

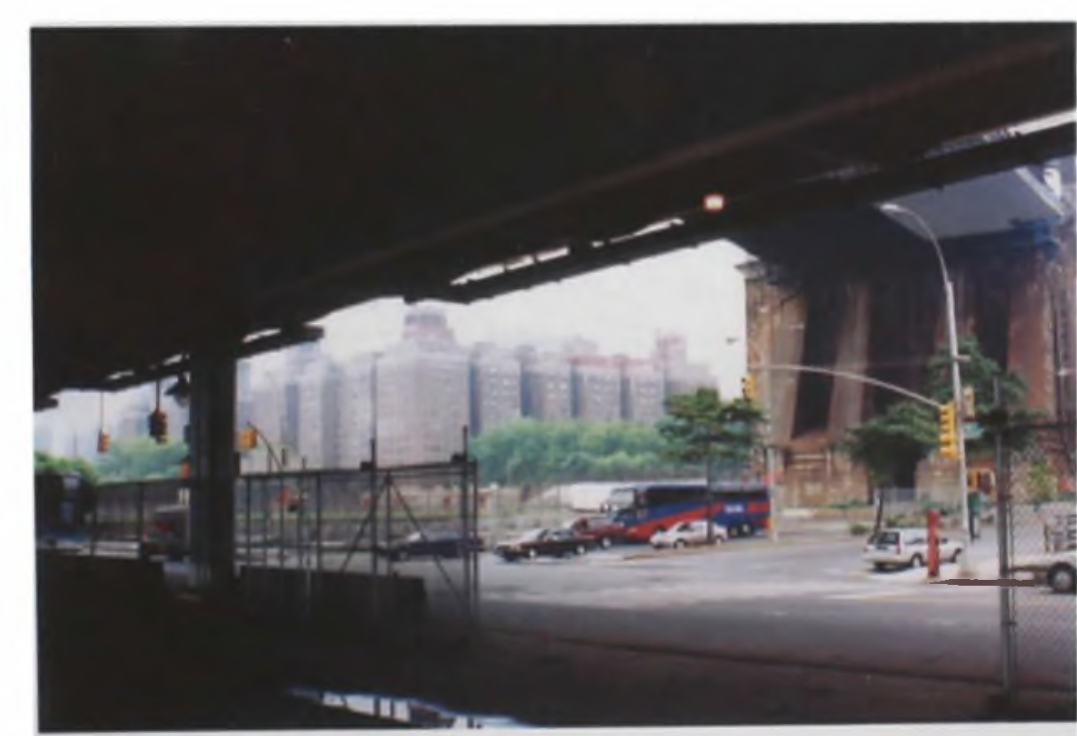

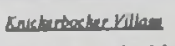

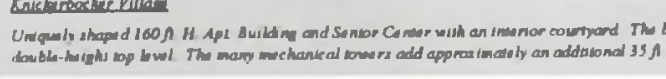

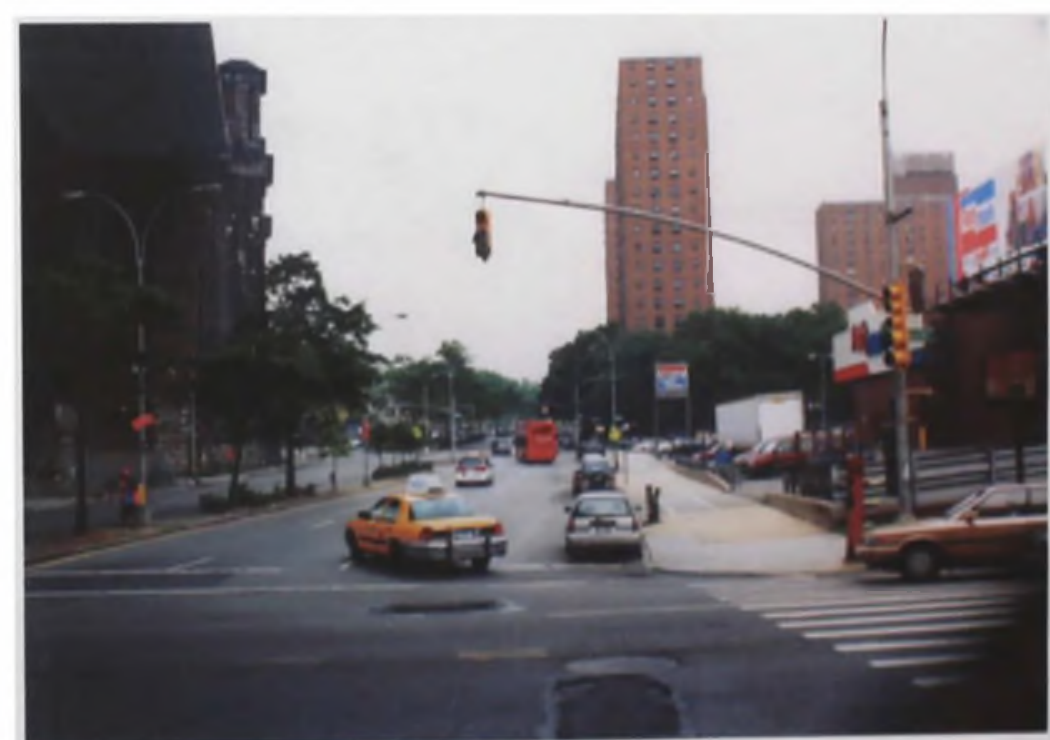

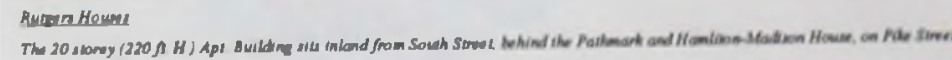



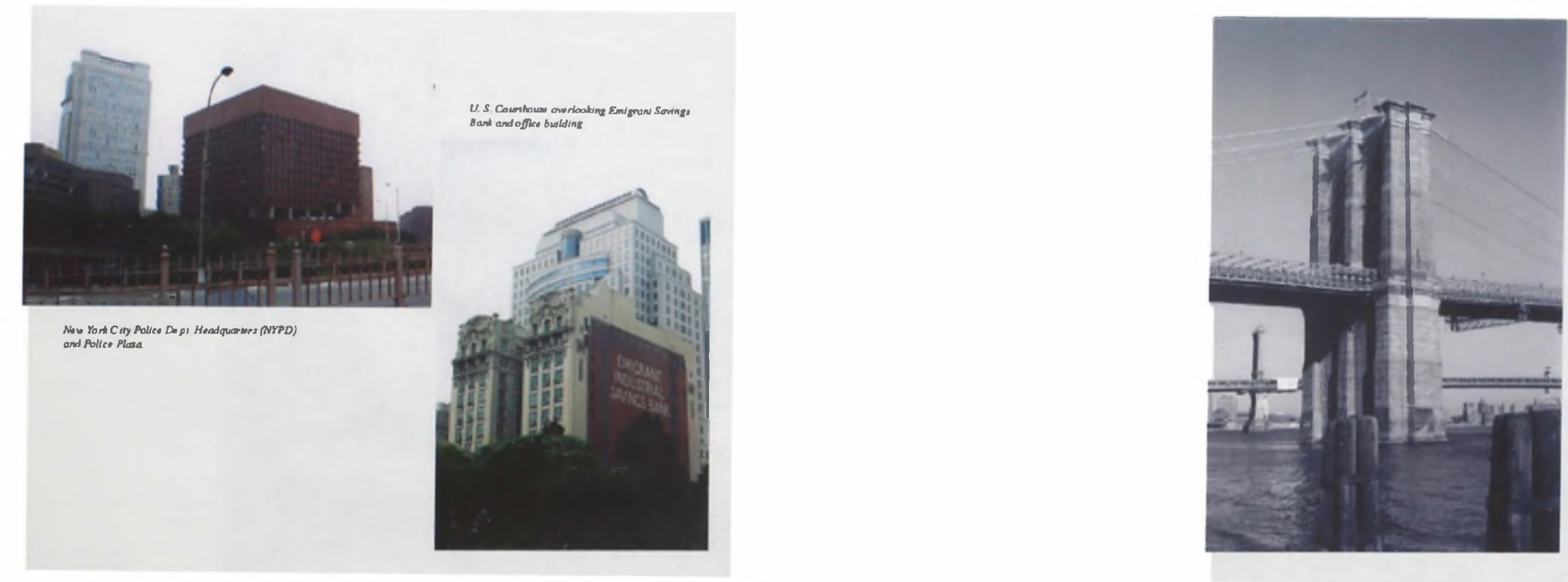

Bnoditin Bnidas

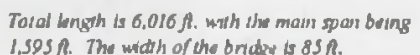

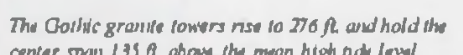

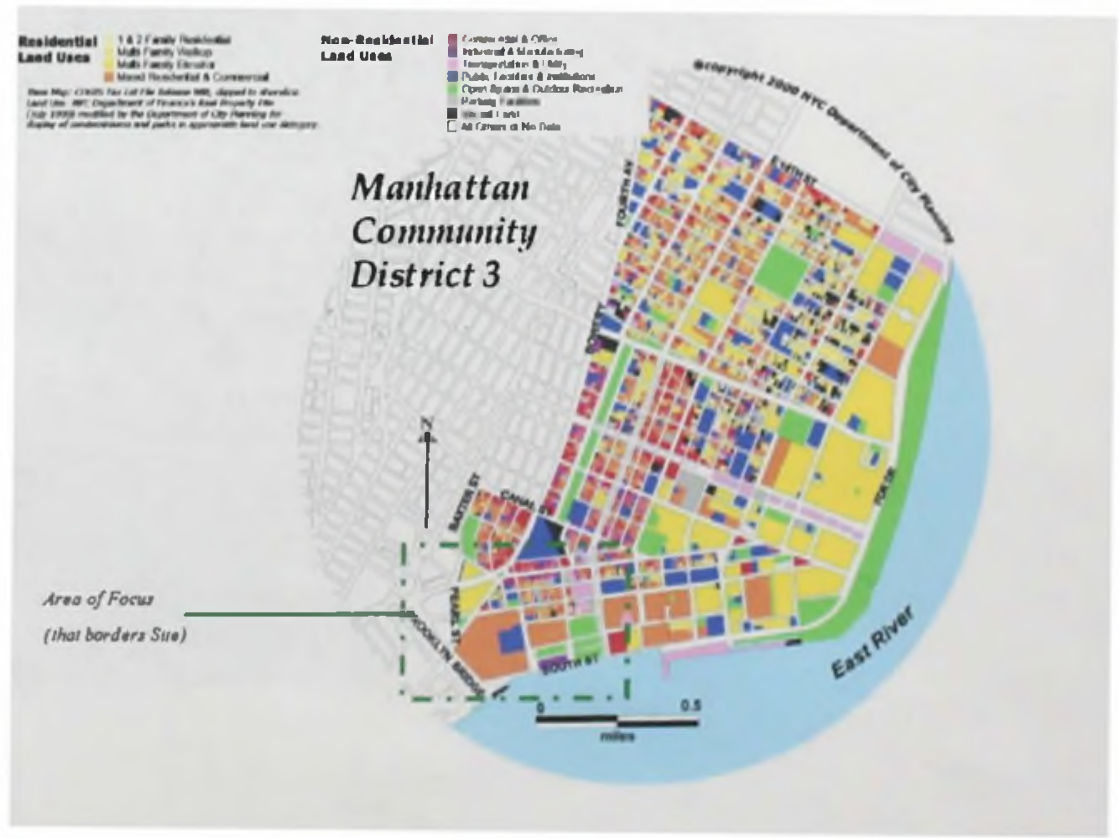




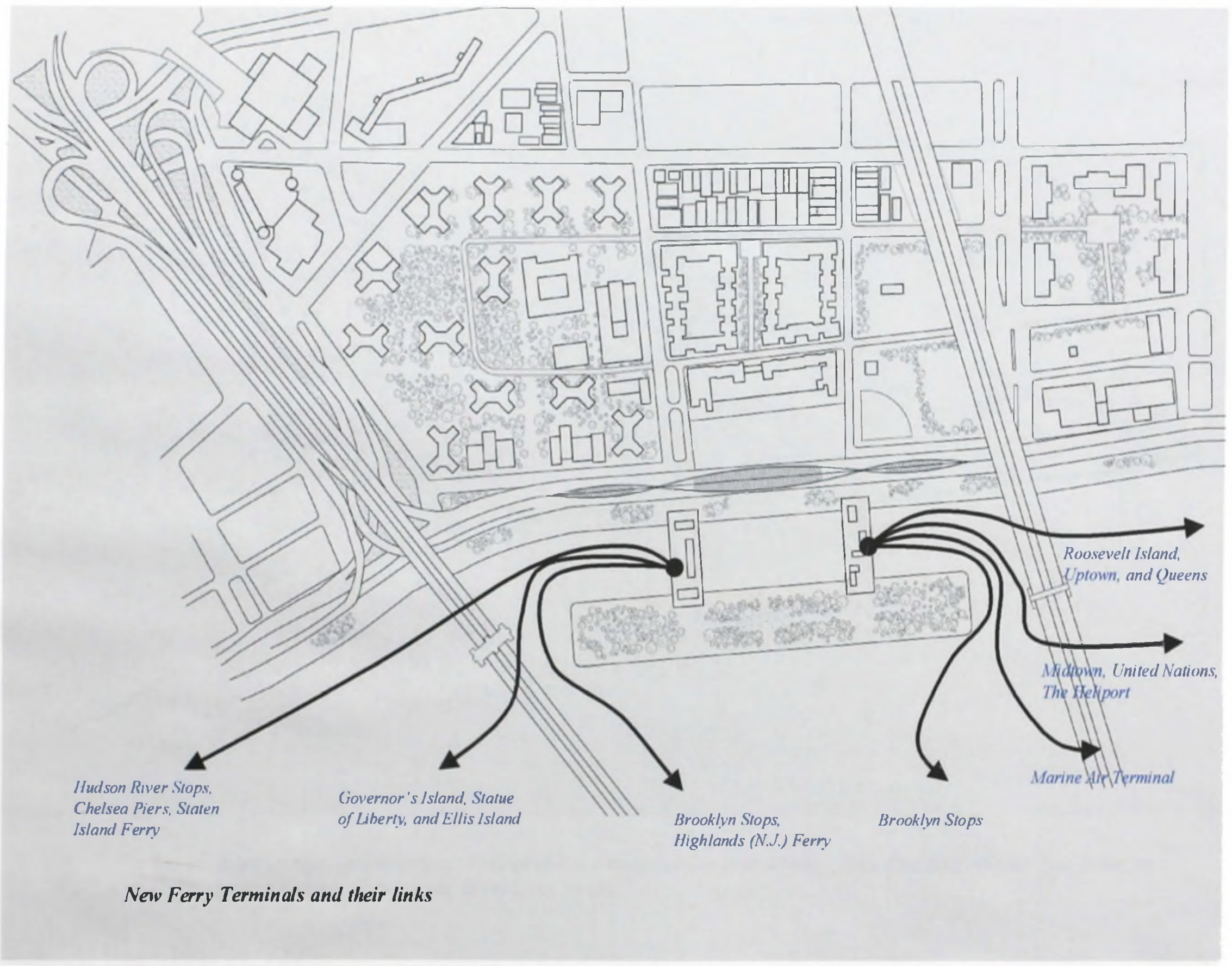




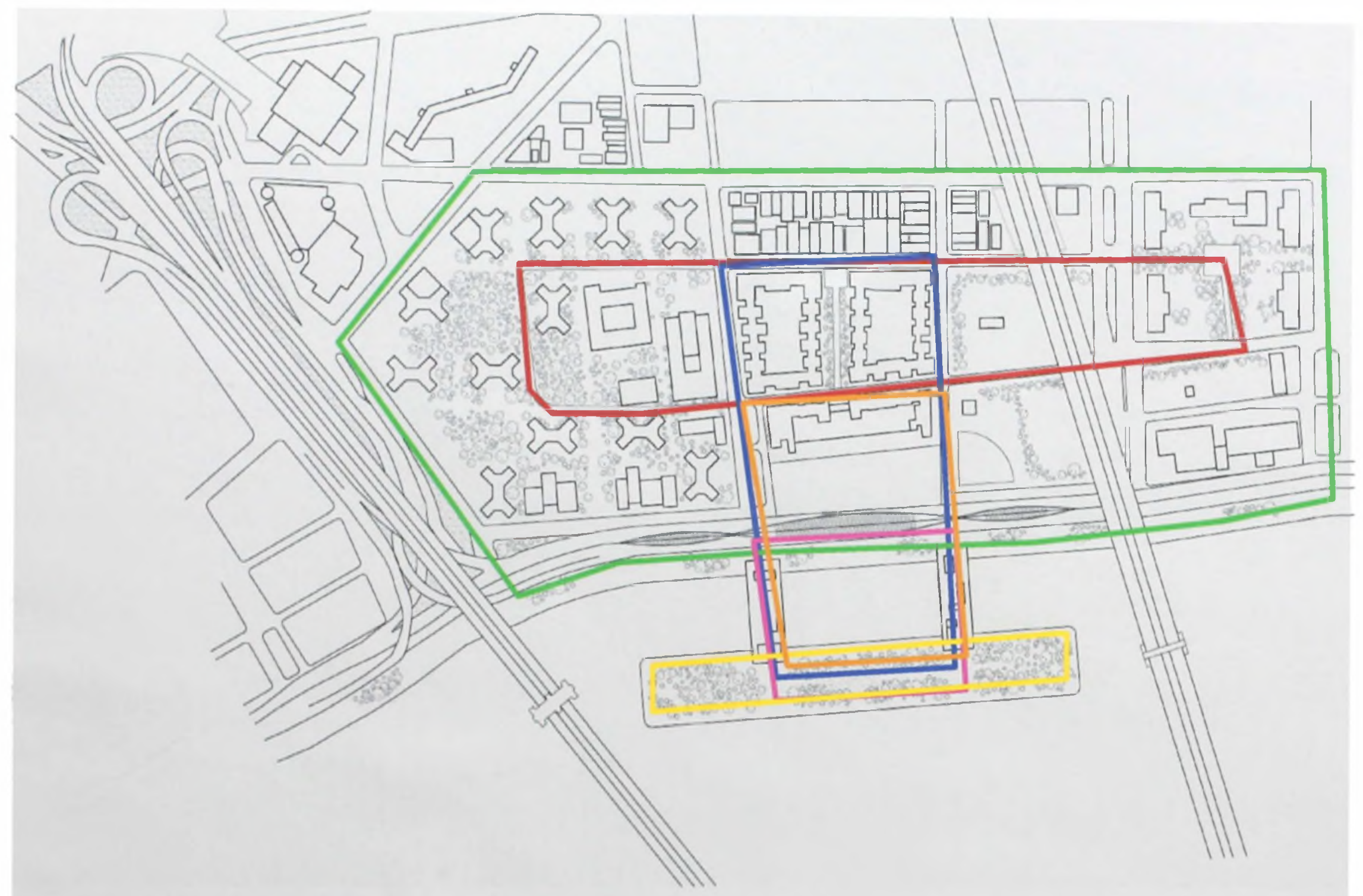

The loops are a series of connectors. They establish a reconnection between the Lower East Side and the East River, as well as unify the connections among the existing blocks. 